WSRC-STI-2008-00309

U. S. Department of Energy

Office of Environmental Management

Paducah Gaseous Diffusion Plant

\title{
Enzyme Activity Probe and Geochemical Assessment for Potential Aerobic Cometabolism of Trichloroethene in Groundwater of the Northwest Plume, Paducah Gaseous Diffusion Plant, Kentucky
}

June 2008

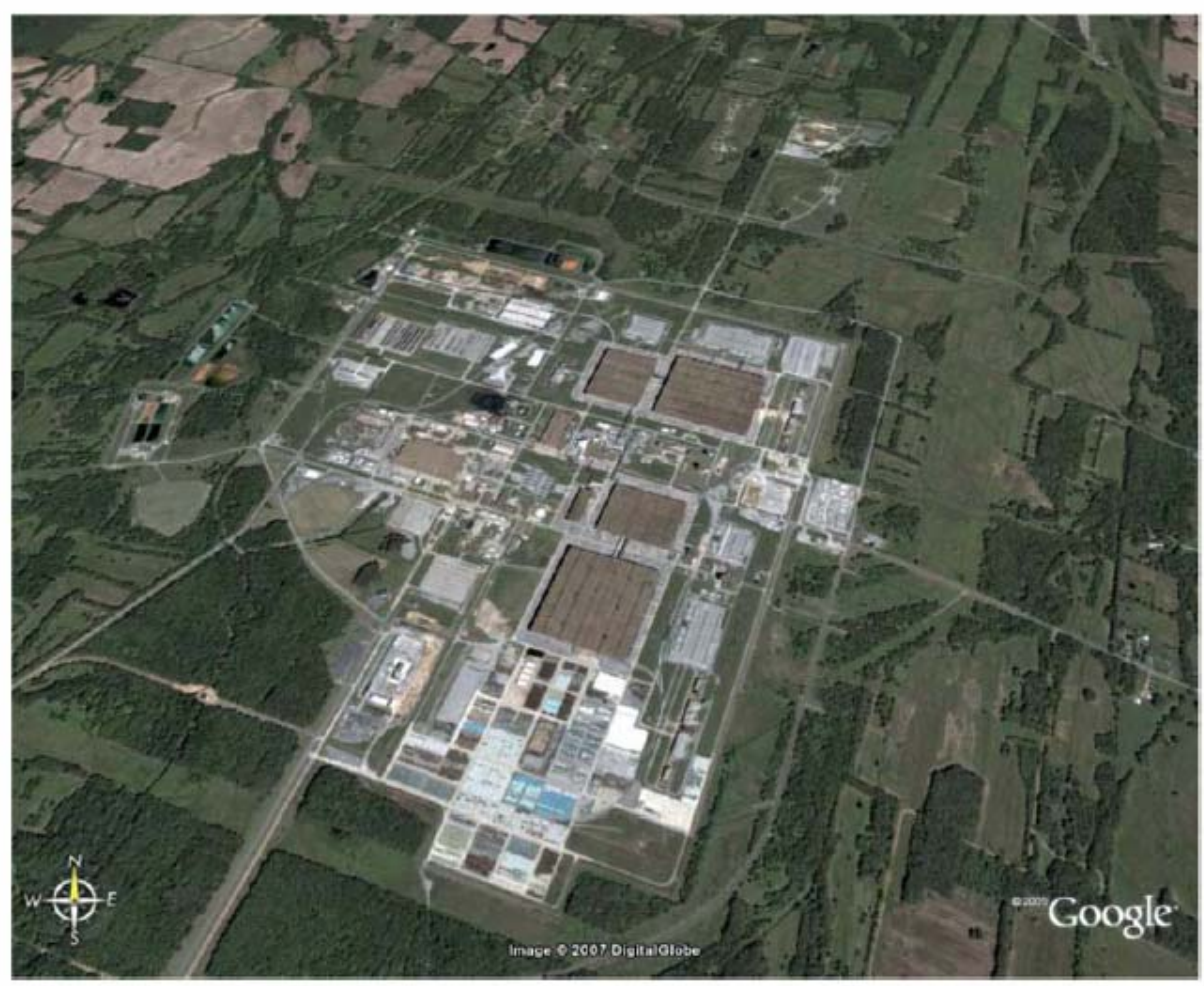

Paducah Gaseous Diffusion Plant (PGDP)

Paducah KY

Prepared for:

Office of Groundwater and Soil Remediation

Office of Engineering and Technology 


\section{DISCLAIMER}

Preparation of this report was coordinated by Washington Savannah River Company (WSRC) for the United States Department of Energy (US DOE) under Contract No. DE-AC09-96SR18500. Careful effort was made by the authors to assure the accuracy of the contents and interpretation. However, the USDOE nor WSRC, nor any of their employees makes any warranty, expressed or implied, or assumes any legal liability for accuracy, completeness, or usefulness, of information, apparatus, or product or process disclosed herein or represents that its use will not infringe privately owned rights. Reference herein to any specific commercial product, process, or service by trade name, trademark, name, manufacturer or otherwise does not necessarily constitute or imply endorsement, recommendation, or favoring of same by WSRC or by the United States Government or any agency thereof. The views and opinions of the authors expressed herein do not necessarily state or reflect those of the United States Government or any agency thereof.

\section{Acknowledgments}

The authors gratefully acknowledge Beth Moore for her leadership within DOE in addressing challenges related to environmental management of large aerobic groundwater plumes that contain chlorinated solvents. Her vision and allocation of resources are appreciated and, along with support from the Department of Defense, are rapidly advancing the scientific knowledge on this topic. The authors also acknowledge the efforts of the PGDP TCE Fate and Transport Team and collaborators including state and federal regulators and scientists. 
U. S. Department of Energy

Office of Environmental Management

Paducah Gaseous Diffusion Plant

\section{Enzyme Activity Probe and Geochemical Assessment for Potential Aerobic Cometabolism of Trichloroethene in Groundwater of the Northwest Plume, Paducah Gaseous Diffusion Plant, Kentucky}

June 2008

Authors:

M. Hope Lee

Brian B. Looney

S. K. Hampson

Department of Energy Project Manager:

Beth Moore, EM-22

Office of Groundwater and Soil Remediation, Engineering and Technology 


\section{Acronyms}

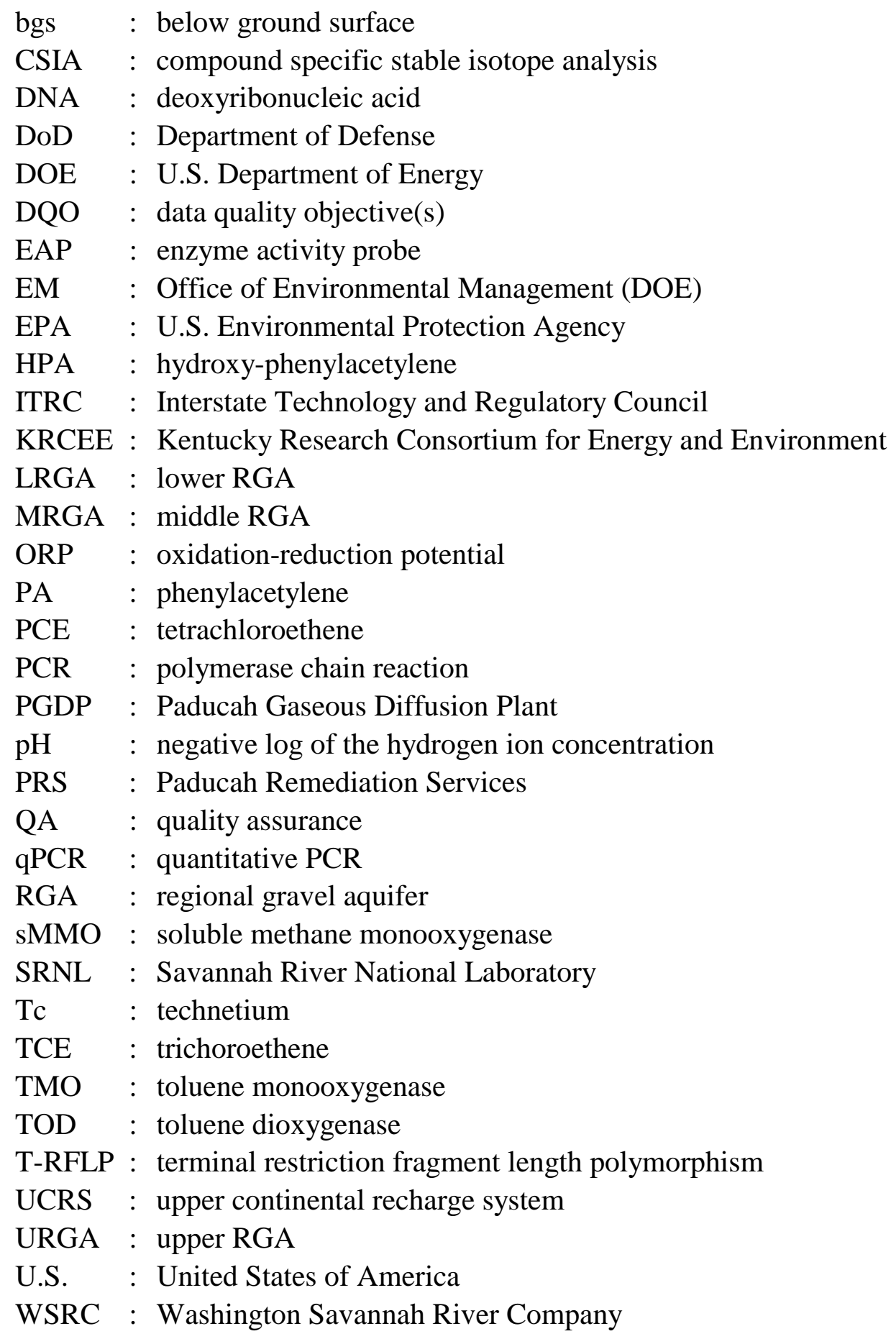




\section{Table of Contents}

Executive Summary $\quad 1$

$\begin{array}{ll}\text { Objectives } & 3\end{array}$

Technical Background $\quad 4$

Cometabolism - How does it contribute to contaminant natural 4 attenuation?

Conceptual Model of Aerobic Cometabolism of Chlorinated Organics in $\quad 7$ Aerobic- "Oligotrophic” Plumes

Enzyme Activity Probes - How do they work? 8

$\begin{array}{ll}\text { Site Background } & 11\end{array}$

General site history, hydrostratigraphy and observed contaminant plumes $\quad 11$

Enzyme activity probe study and related efforts $\quad 15$

Methods 19

Enzyme Activity Probes 19

Toluene Enzyme Activity Determination $\quad 19$

sMMO Enzyme Activity Determination $\quad 21$

DNA Extraction and PCR Amplification - "DNA Control Study” 23

Supplementary Microbial Diversity “T-RFLP” Study 23

Geochemical Parameters $\quad 24$

Compound Specific Isotope Analysis 26

$\begin{array}{ll}\text { Results } & 27\end{array}$

Enzyme Activity Probes 27

Qualitative Toluene and sMMO Enzyme-Activity Probe Results 27

Quantitative Toluene Enzyme-Activity Probe Results 29

DNA Control Study Results 32

Supplementary T-RFLP Study Results $\quad 34$

Geochemical Results $\quad 34$

Compound Specific Isotope Analysis Results 36

Discussion and Key Findings $\quad 37$

$\begin{array}{ll}\text { References } & 39\end{array}$

Appendices -

A. Raw Geochemical Data

B. Detailed T-RFLP Report 


\section{List of Figures}

1. Some of the cometabolic pathways for TCE $\quad 7$

2. Schematic diagram of the enzyme activity probe concept 10

3. Calendar Year 2005 TCE Plumes in the RGA Underlying PGDP 12

4. Calendar Year $2005^{99}$ Tc Plumes in the RGA Underlying PGDP 13

5. PGDP geologic/hydrogeologic conceptual model 14

6. Wells sampled to support the assessment of attenuation processes 16 in the Northwest Plume, PGDP

7. $\quad$ Schematic diagram of PGDP NW Plume and the wells selected 18 by the Project Team

8. Schematic diagram of the steps in toluene enzyme activity determinations 20

9. Schematic diagram of the steps in sMMO enzyme activity determinations 22

10. T-RFLP schematic 24

11. Micrograph of groundwater from MW66 exposed to phenylacetylene (PA). $\quad 29$

12. Map displaying wells where either sMMO enzyme-activity probe and/or 31 one or more toluene enzyme-activity probes are significant

\section{List of Tables}

1. Supporting Geochemical and Field Measurements 25

2. $\quad$ Preliminary results of EAP (qualitative) 28

3. $\quad$ EAP assay results (quantitative) 30

4. Results of DNA control studies 33

5. Relationships between EAPs, PCR, and toluene (aromatic) enzymatic pathways 33

6. Summary of key geochemical characteristics in the PGDP Northwest Plume 35

7. Summary of CSIA results 36 


\section{Executive Summary}

Portions of the groundwater underlying the Paducah Gaseous Diffusion Plant (PGDP) are contaminated by chlorinated solvents, principally trichloroethene (TCE), as well as other contaminants such as technetium-99 $\left({ }^{99} \mathrm{Tc}\right)$. Keys to effective long-term environmental management of the PGDP Site are: understanding, mitigating and ensuring that risks from the groundwater contaminant plumes are low and that the site will achieve regulatory goals in an acceptable time frame. Identification of the important mechanisms that impact the fate of TCE in PGDP plumes and documentation of TCE degradation rates for these active mechanisms are integral to this effort. A TCE Fate and Transport project scoping team (Project Team) was assembled to coordinate study of the migration of TCE and controlling processes in the groundwater at PGDP.

\section{Key point:}

Aerobic cometabolism is occurring throughout the Northwest Plume at PGDP and is contributing to the degradation and attenuation of TCE.

The Project Team consists of representatives from Paducah Remediation Services (PRS) and Portage Environmental, the Commonwealth of Kentucky Division of Waste Management, The Environmental Protection Agency (EPA) Region 4, and the Kentucky Research Consortium for Energy and Environment (KRCEE). This team was supported by representatives of the EPA Robert S. Kerr Laboratory in Ada OK, the University of Oklahoma, Savannah River National Laboratory (SRNL), North Wind Inc. and others. The DOE Paducah Portsmouth Project Office (PPPO) and the DOE Office of Environmental Management (EM) sponsored the efforts of the team. All of the individuals and organizations contributed to the planning and execution of this research and worked to identify the wells used in the Northwest Plume, and established the research data quality objectives (DQOs).

Recent and emerging data from diverse sites across the U.S. suggest that cometabolism may be a significant TCE degradation mechanism occurring in aerobic contaminant plumes. Since PGDP groundwater is generally aerobic, elucidating the potential site-specific significance of cometabolism is central to the efforts and studies of the Project Team.

The PGDP aerobic cometabolism assessment was conducted in the Northwest Plume located within the regional gravel aquifer (RGA). This assessment was based on enzyme activity probe (EAP) assays supplemented by multiple lines of supporting evidence, including molecular techniques, stable carbon isotope analysis, and geochemical measurements for 10 RGA wells that are located along the plume centerline and 2 control wells located outside the footprint of the Northwest Plume. The various EAP assays each provide a clear, definitive fluorescent signal if a particular "oxygenase" enzyme is active at the time of analysis. The assays test either for the enzyme that oxidizes methane (soluble methane mono-oxygenase) or for one of a suite of enzymes that oxidize aromatic compounds (e.g., toluene oxygenases). The specific enzymes that are targeted with EAPs are representative of those that have been documented to break down TCE. Such enzymes result in degradation and subsequent mineralization of TCE to harmless end products such as carbon dioxide and chloride ions. If detected, the enzymes are active and capable of cometabolic degradation of TCE. 
For the 10 wells within the Northwest Plume: $80 \%$ showed significant presence of toluene oxidizers, 50\% showed significant sMMO activity, and 90\% showed at least one type of oxidizing capability. Vertically within the RGA, the expression and activity in the upper and lower portions of the RGA had particularly diverse and robust EAP signals.

The EAP data indicate that aerobic cometabolic activity is occurring throughout the Northwest Plume at PGDP and is contributing to the attenuation of TCE. The positive EAP responses in the control wells from outside the plume suggest that there is a widespread potential for the aerobic degradation of TCE. The geochemistry throughout the PGDP Northwest Plume was spatially variable, but all of the wells had geochemical conditions that are generally consistent with those required for aerobic cometabolism. To address the representativeness of the microbial population samples, a supplementary study of community characteristics was performed. These supplementary data provide scientifically and statistically defensible results that the groundwater sampled and analyzed for enzyme probe activity primarily represents sampling of the groundwater plume (i.e. formation water), rather than sampling the micro-communities present in specific and/or individual well casings, or biofilms present therein.

The specific goals for this aerobic cometabolism assessment were developed by the Project Team and are presented in detail in the document - TCE Fate and Transport Project Evaluation of Aerobic Degradation Enzyme Activity Probe Sampling Scoping Document (KRCEE, 2007). Based on the results of this effort, the following decision/estimation determinations were developed (which correlate with the five key questions from the Project Team):

o Decision / Estimation Statement \#1. Bacteria capable of aerobically biodegrading TCE are present in the PGDP Northwest Plume.

o Decisions / Estimation Statement \#2. Stable isotope information will be developed based on evaluation of compound specific isotope analysis (CSIA) in a companion report.

o Decision / Estimation Statements \#3. The number and distribution of bacteria are sufficient to contribute to the biodegradation of TCE in RGA groundwater. The organic carbon in this oligotrophic, "nutrient limited" system is low and the microbial community appears to be stable and sustainable (e.g., the control wells were similar to plume wells).

o Decision / Estimation Statement \#4. Based on the information collected during the initial phase of work, a follow-on kinetic (rate) study was recommended for consideration by the TCE Fate and Transport Team. The objective of this study would be development of an independent site-specific degradation rate constant. Two wells, MW125 and either MW236 or MW381 appear to be promising for the kinetic study phase of the work based on: a) location in the mid to distal plume area where attenuation processes are particularly important, b) representative EAP responses, c) representative geochemistry, etc.

0 Decision / Estimation Statement \#5. The previously estimated degradation rates for PGDP based on comparison of plume scale TCE transport to a conservative tracer $\left({ }^{99} \mathrm{Tc}\right)$ are consistent with the published literature for aerobic cometabolism in large aerobic plumes (half life in the range of 9 to 25 years). Additional kinetic data for multiple sites across the U.S. are being developed through research funded by DOE and DoD. These data will be finalized and published and available to support the final estimated rates for PGDP. 


\section{Objectives}

The overarching objective of the Paducah Gaseous Diffusion Plant (PGDP) enzyme activity probe (EAP) effort is to determine if aerobic cometabolism is contributing to the attenuation of trichloroethene (TCE) and other chlorinated solvents in the contaminated groundwater beneath PGDP. The site-specific objective for the EAP assessment is to identify if key metabolic pathways are present and expressed in the microbial community - namely the pathways that are responsible for degradation of methane and aromatic (e.g. toluene, benzene, phenol) substrates. The enzymes produced to degrade methane and aromatic compounds also break down TCE through a process known as cometabolism. EAPs directly measure if methane and/or aromatic enzyme production pathways are operating and, for the aromatic pathways, provide an estimate of the number of active organisms in the sampled groundwater. This study in the groundwater plumes at PGDP is a major part of a larger scientific effort being conducted by Interstate Technology and Regulatory Council (ITRC), U.S. Department of Energy (DOE) Office of Environmental Management (EM), Savannah River National Laboratory (SRNL), and North Wind Inc. in which EAPs are being applied to contaminated groundwater from diverse hydrogeologic and plume settings throughout the U.S. to help standardize their application as well as their interpretation.

While EAP data provide key information to support the site specific objective for PGDP, several additional lines of evidence are being evaluated to increase confidence in the determination of the occurrence of biodegradation and the rate and sustainability of aerobic cometabolism. These complementary efforts include:

o Examination of plume flowpaths and comparison of TCE behavior to "conservative" tracers in the plume (e.g., ${ }^{99} \mathrm{Tc}$ )

o Evaluation of geochemical conditions throughout the plume

o Evaluation of stable isotopes in the contaminants and their daughter products throughout the plume

If the multiple lines of evidence support the occurrence of cometabolism and the potential for the process to contribute to temporal and spatial attenuation of TCE in PGDP groundwater, then a follow-up enzyme probe microcosm study to better estimate biological degradation rate(s) is warranted. 


\section{Technical Background}

\section{Cometabolism - How does it contribute to contaminant natural attenuation?}

Accurate prediction of, and response to, potential future impacts from TCE and organic-solvent contaminated groundwater requires that the key processes that impact the fate and transport of the contaminant in the groundwater environment be identified and quantified. A number of physical, chemical, and biological processes affect the fate of TCE and other contaminants in a groundwater plume. Physical and chemical processes include advection, dispersion, sorption, dilution and degradation. Biological processes include aerobic and anaerobic metabolism and cometabolism by organisms indigenous to the particular groundwater environment.

Cumulatively, the chemical, physical and biological processes that affect a contaminant's fate are referred to as natural attenuation processes.

A decision to rely on natural attenuation processes as part of a site-remediation strategy depends on the combined effectiveness of all the various attenuation processes, along with remediation and source treatment actions, to meet site-specific remediation goals. Remediation goals for chlorinated solvents include low risk, demonstrable plume stability, documentation of the expression of accepted and sustainable attenuation processes, and projection of an acceptable remedial time frame. DOE, the U.S. Environmental Protection Agency (EPA) and other agencies have developed a number of relevant guidelines and protocols, including:

- Scenarios Evaluation Tool for Chlorinated Solvent Monitored Natural Attenuation (MNA), WSRC-STI-2006-00096, Rev. 1 (SRNL, 2006) to help identify key natural attenuation processes for a particular site

o Technical Protocol for Evaluating Natural Attenuation of Chlorinated Solvents in Groundwater, EPA/600/R-98/128 (EPA, 1998), to help quantify the role of particular natural attenuation processes and to help determine the appropriateness of an attenuation based remedy

In the Technical Protocol, EPA relies on multiple lines of evidence to identify and account for the significance of natural attenuation processes to impact contaminant fate and transport. The "First Line of Evidence" is based on evaluation of contaminant and daughter product concentration trends over time and space at monitoring wells along a contaminant plume's flow path. The "Second Line of Evidence" consists of the identification and recognition of specific attenuation processes and hydrogeochemical conditions to support those processes. If needed, the "Third Line of Evidence" aims to confirm site specific degradation processes and establish a degradation rate (e.g., a contaminant half life) through the use of a microcosm, or an alternative laboratory or field study. These traditional lines of evidence remain central to identifying and quantifying attenuation processes, especially for sites with anaerobic groundwater conditions that are suited to reductive biological and abiotic degradation processes. 
The Technical Protocol for natural attenuation of chlorinated solvents (EPA, 1998) recognizes that, over time, a variety of additional biotic and abiotic attenuation mechanisms will be identified and documented in the scientific literature. The Technical Protocol provides specific guidance for including a "Third Line of Evidence" for emerging degradation mechanisms in the evaluation of natural attenuation. The "Third Line of Evidence" includes the use of microcosm data, modeling, technical evaluation, and documentation of the geochemical conditions. This "Third Line of Evidence" is particularly important for sites with biogeochemical conditions that do not support the traditionally emphasized anaerobic natural attenuation processes.

Enzyme probes and related microcosms focus on documenting and quantifying aerobic cometabolism and represent an opportunity to cost-effectively contribute to the requirements of the Third Line of Evidence.

Degradation of chlorinated ethenes by microbial communities has been extensively studied over the past 20 years. While some of the earliest efforts focused on aerobic cometabolism (Wilson and Wilson, 1985), the focus of natural attenuation research quickly shifted toward anaerobic processes (EPA, 1998). Anaerobic processes have been shown to occur reliably at a significant number of contaminated sites (sites that have low levels of dissolved oxygen, sulfate and other electron acceptors in the groundwater) and to rapidly degrade many chlorinated solvents through a series of identifiable daughter products.

Aerobic cometabolism is a process in which available organic matter in an aerobic environment induces the production of specific types of enzymes that are also capable of breaking down a contaminant such as TCE. During the 1980s and 1990s, interest in cometabolism (see Grindstaff, 1998, and Fries et al., 1997) focused on active bioremediation via addition of short-lived substrates such as methane, propane, toluene and phenol to facilitate degradation. However, there was little focus on quantifying the potential role of cometabolism in aerobic groundwater environments as a significant component of natural attenuation. Under natural conditions, aerobic cometabolism rates tend to be relatively slow and do not produce easilyobservable diagnostic daughter products. Rather, aerobic cometabolism results in the

\section{A few important definitions}

enzyme - a biological catalyst that speeds up the rate of a reaction.

substrate -- a substance on which an enzyme acts.

The enzymes that are important to aerobic cometabolism are "oxygenases," chemicals that help break down a target molecule by inserting oxygen. Most enzymes catalyze one type of reaction and act on one primary substrate and sometimes act on related compounds. The link between enzymes and substrates is often tight so that enzymes are typically named after the primary substrate and reaction, simply by adding the suffix “ase." For example, toluene 2-

monooxygenase inserts an oxygen atom into toluene at the designated location. The substrates that are important to aerobic cometabolism are those that encourage the production of oxygenases that are "promiscuous," meaning that they oxidize a relatively wide range of compounds besides the primary substrate. For aerobic cometabolism, the enzyme oxidizes a contaminant such as TCE in addition to the primary substrate. Primary substrates that are known to result in TCE cometabolism include chemicals like toluene that contain "aromatic" carbon rings and simple carbon or nitrogen compounds like methane, propane or ammonia. 
fortuitous degradation of the contaminant to carbon dioxide, water and chloride. Recently, however, aerobic cometabolism has been documented to occur at rates that can meaningfully contribute, in appropriate aerobic settings, to natural attenuation and stabilization of contaminant plumes (Lee et al., 2005; 2008; Wymore et al., 2007) leading to a renewed interest in cometabolism under natural conditions.

Chlorinated ethenes, including trichloroethene, are among the most common and most widespread contaminants in soil and groundwater. Notable examples within DOE include the Savannah River Site in SC, PGDP in KY, the Oak Ridge Site in TN, the Idaho National Laboratory (INL) in ID, the Hanford Reservation in WA, the Sandia and Los Alamos National Laboratories in NM, and the Lawrence Livermore National Laboratory in CA. At many chlorinated ethene contaminated sites, including all of these major DOE facilities, the contaminated groundwater often contains dissolved oxygen. Thus, the primary natural attenuation mechanisms that are widely recognized, reductive biological and abiotic destruction, are not active at these sites. Recent laboratory and field activities have documented that EAPs, in combination with DNA confirmation, can be used to identify and quantify groups of organisms that are actively contributing to aerobic cometabolism (Lee et al., 2005; 2008; Wymore et al., 2007). Through the utilization of laboratory microcosms these researchers have developed protocols to estimate degradation rates and relate the rate results to field conditions (Lee et al., 2005) as Third Lines of Evidence for the Technical Protocol.

Concurrent and ongoing progress in the related area of compound specific stable isotope analysis (CSIA) constitutes an additional "Third Line of Evidence" for the occurrence of biotic and abiotic degradation processes impacting chlorinated ethenes in groundwater. The CSIA research has successfully linked plume-scale changes in the profiles of stable carbon and hydrogen isotope ratios within the molecules of the contaminants and daughter products along a plume flowpath to the expected fractionation caused by different degradation processes - in some cases, these data help narrow down the degradation process(es) and the rate of degradation.

Because many of the major DOE solvent plumes occur in aerobic groundwater in a variety of hydrogeologic and geochemical settings, the various scientific developments related to identification and quantification of aerobic microbial activity have the potential to be transformational to the DOE EM Program. Documenting significant and sustainable attenuation at a site will facilitate a disciplined and defensible transition of cleanup activities to monitored natural attenuation or enhanced attenuation.

\section{Key Point:}

While aerobic cometabolism has been applied as an in situ engineered remedy at several sites, traditional thinking has been that cometabolism is of limited importance to natural attenuation due to slow degradation rates in typical environmental conditions. Recent work has suggested that cometabolism may substantively contribute to monitored natural attenuation (MNA) at some sites where groundwater is contaminated by chlorinated ethenes. 


\section{Conceptual Model of Aerobic Cometabolism of Chlorinated Organics in Aerobic- “Oligotrophic” Plumes}

Figure 1 summarizes some of the documented cometabolism pathways for TCE. Note that the initial step in each of the pathways is the oxidation of TCE by an enzyme that is actually being produced to target an aromatic compound (i.e, toluene), a light hydrocarbon (i.e., methane or propane), or another compound (i.e., ammonia). The oxidation of these "primary substrates" typically involves insertion, or addition, of oxygen to the molecule. The primary substrates are all relatively difficult to oxidize and the enzymes produced to oxidize them tend to be promiscuous. Therefore, these enzymes often capable of oxidizing a variety of nontarget compounds such as chlorinated solvents (e.g., Figure 1) and the EAP test reagents (as described in the next section).

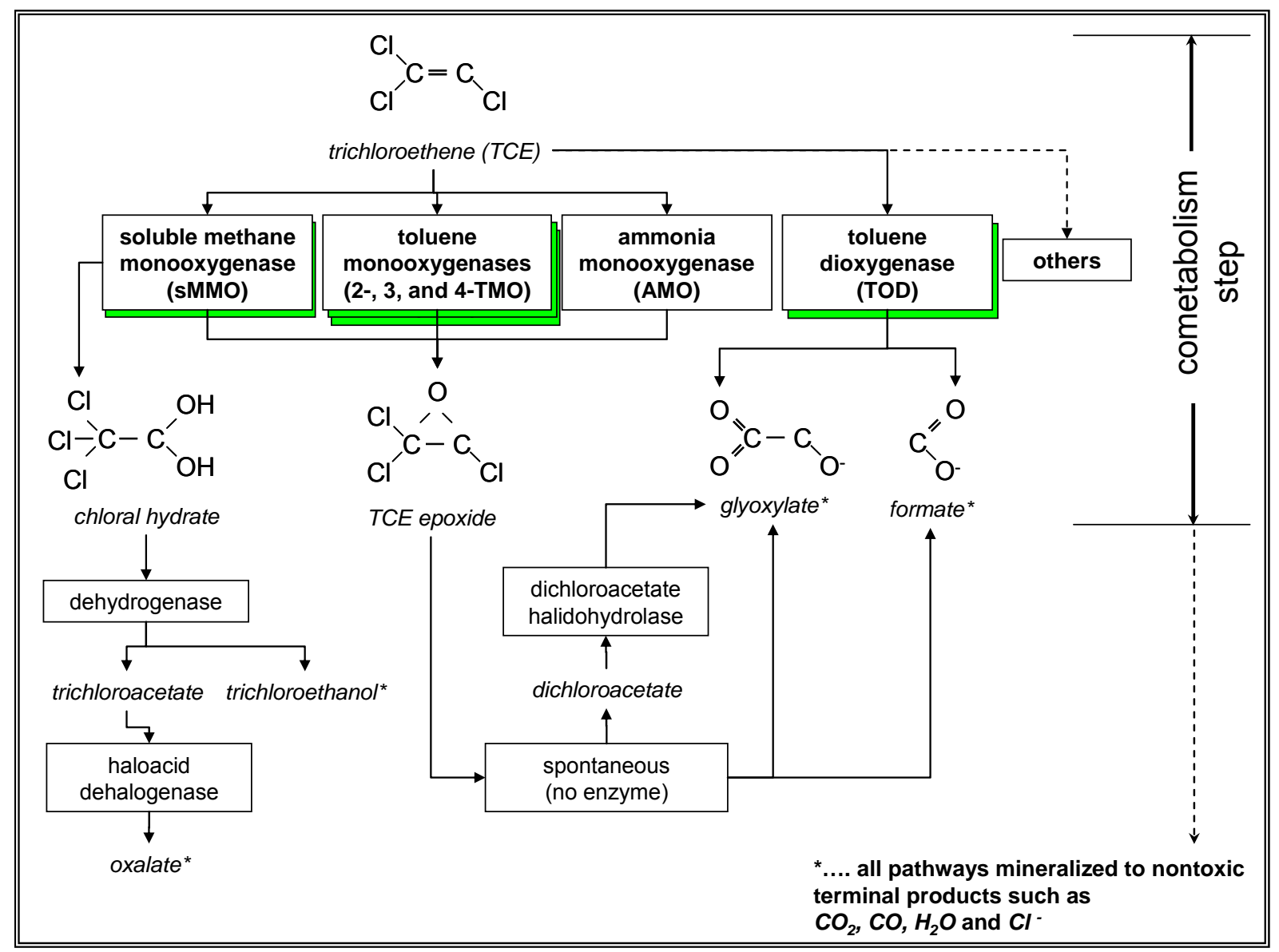

Figure 1. Some of the cometabolic pathways for TCE

(this figure represents a compilation of pathways documented in the University of Minnesota

Biocatalysis/Biodegradation Database, http://umbbd.msi.umn.edu/ )

Existing EAP assays available for the highlighted items 
An ecosystem or environment that offers little to sustain life is termed oligotrophic: a word derived from the Greek oligo meaning small or few and trophe meaning nutrients or food. Many groundwater systems, even those that are contaminated by chlorinated solvents, are oligotrophic so that the microorganisms that live there are "starving." In these systems, there is selective pressure favoring "low nutrient specialists." In some cases, these organisms survive by recycling carbon released from the decay of previous generations. In other cases, however, the organisms are thought to survive by slowly degrading recalcitrant natural organic carbon sources, such as humic and fulvic acids. Thus, we propose the following hypotheses:

o Because of the ecological pressures in oligotrophic aquifers, slow utilization of the recalcitrant natural organic matter is a potential contributor to the carbon/energy need of the ecosystem.

o Because natural organic matter is approximately 30\% aromatic, microorganisms that produce enzymes capable of oxidizing recalcitrant aromatic compounds will be a significant component of the microbial community. Note that co-contaminants can also support a microbial community capable of cometabolism and that remediation technologies based on amendment with aromatic substrates or light hydrocarbons have been documented (e.g., DOE, 1995, McCarty et al., 1998, Fries et al., 1997).

o Because many enzymes that oxidize recalcitrant aromatic compounds also degrade chlorinated solvents by cometabolism, chlorinated solvents are being slowly degraded and attenuated in oligotrophic aerobic groundwater plumes.

The data collected at Paducah, in combination with the data being collected in other large aerobic plumes will be used to test these hypotheses and determine the significance of cometabolism as an attenuation mechanism and the impact of cometabolism on plume stabilization and plume size.

\section{Enzyme Activity Probes - How do they work?}

Cometabolic oxidation results in mineralization of the contaminant to common inorganic species (e.g, carbon dioxide and chloride ion). As a result, the traditional chemical evidence for cometabolic degradation is the presence of appropriate conditions (i.e., dissolved oxygen and an appropriate carbon substrate) and the disappearance of the contaminants themselves (unlike anaerobic processes where detection of intermediate daughter products provides clear evidence of degradation). Emerging methods such as EAPs and CSIA have the potential to advance the assessment of cometabolism. The first provides a tool to directly measure if key enzymes are active in situ. The second provides a tool to examine the ratio of stable isotopes in the contaminant molecules throughout the plume to (a) determine if isotopic fractionation resulting from degradation processes is observable and (b) to provide insight into the specific processes (abiotic, anaerobic, aerobic, etc.) and rates of those processes. 
Traditional microbial methods for assessing bacteria capable of cometabolism looked for the presence of particular DNA sequences. These methods do not provide evidence of actual enzyme production in the field (i.e., enzyme activity), but rather indicate either the presence or the potential for enzyme activity. However, EAPs have recently been developed that specifically assess both the presence and activity of specific microorganisms in contaminated subsurface environments. These probes are innovative tools that provide direct evidence that the mechanism for aerobic cometabolic oxidation is present and active in an aquifer. EAPs are compounds that take advantage of the nonspecificity of the cometabolic enzyme of interest and its ability to oxidize compounds other than the primary substrate. Probes that serve as alternate substrates for several of the "promiscuous" enzymes that are capable of cometabolizing TCE have been developed. These include probes for enzymes that target aromatic compounds (e.g., toluene, phenol, benzene), and enzymes such as soluble methane monooxygenases (sMMO) that target light hydrocarbons such as methane (Keener et al., 1998; 2001; Miller et al., 2002; Kauffman et al., 2003; Clingenpeel et al., 2005). These colorless probes undergo transformation to yield a fluorescent product only when the enzyme of interest is actively functioning. The specific probes used in this assessment include the sMMO probe coumarin and three aromatic enzyme probes: phenylacetylene (PA), 3-hydroxy-phenylacetylene (3HPA) and transcinnamonitrile. If the appropriate enzyme is not present, or it is present but not active in a given sample, then the probes will not be transformed and no fluorescence will be detected.

The general concept of the EAP is shown in Figure 2. Note that the "probe" is not a physical piece of equipment, such as a probe used with a $\mathrm{pH}$ meter, but rather, is a chemical that is added to a sample for a short time (10 to 15 minutes). Each probe is a commercially-available nonfluorescent compound that is transformed by a targeted enzyme (if present) into a fluorescent molecule that is easily quantifiable by microscopy or fluorometry. The compounds used as EAPs are selected to indicate a particular enzyme, or closely related enzymes. A short exposure period is used to avoid induction of the enzyme by the presence of the probe molecules. Thus, a positive result means that the enzyme has been induced by environmental conditions, and the enzyme is being produced in that environment.

EAPs measure the actual activity of microorganisms and represent in situ conditions as sampled in water from the subsurface. As noted above, molecular techniques (i.e., DNA analysis) provide evidence that the blueprint for the enzyme is present; therefore, these methods are used as a control analysis and to provide context for the EAP results. Microbial DNA can be extracted out of water, soil, or sediment samples and used in molecular assays. These assays are designed to look for the presence of the genes coding for the biological oxygenases. Coupling molecular assessments with EAP analyses provides direct and supporting evidence of cometabolic enzyme activity toward chlorinated solvents (Lee et al., 2005; 2008; Wymore et al., 2007). Natural attenuation of TCE through cometabolism can be verified using this type of complementary monitoring technique. 


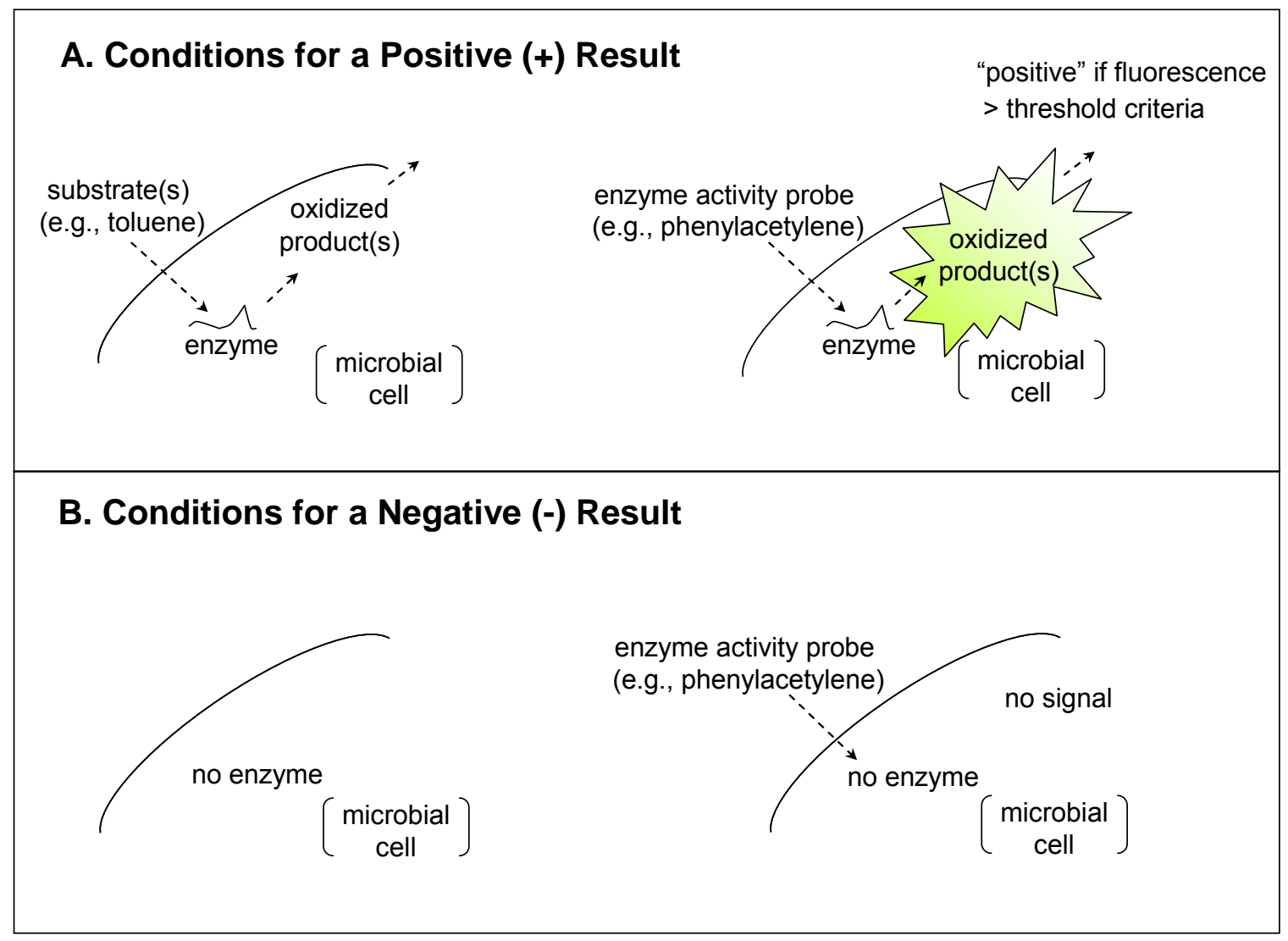

Figure 2. Schematic diagram of the enzyme activity probe concept showing a positive result $(A)$ and a negative result $(B)$.

Additional lines of evidence being collected to support evaluation of natural attenuation in PGDP groundwater include the following:

o Examination of plume stability

o Comparison of TCE behavior to "conservative” tracers

o Evaluation of geochemical conditions throughout the plume

o Evaluation of stable isotopes in the contaminants and daughter products throughout the plume. 


\section{Site Background}

\section{General site history, hydrostratigraphy and observed contaminant plumes}

The groundwater underlying the PGDP is contaminated by chlorinated solvents, principally trichloroethene (TCE; Figure 3), as well as other contaminants such as ${ }^{99}$ Tc (Figure 4). TCE was released as a dense nonaqueous phase liquid (DNAPL) to subsurface soils and groundwater as a result of operations that began in 1952. As shown in Figure 3, the Building C-400 area is coincident with the highest TCE concentrations (i.e., the centroid) in the groundwater plumes at PGDP. While there are other known and potential sources of TCE at PGDP (e.g., various hazardous and radioactive burial grounds and disposal facilities), the residual contamination in the vicinity of Building C-400 is a dominant historical and current source of TCE solvent contributing to the large PGDP groundwater plume(s). PGDP is in the final planning phases for removing residual DNAPL contaminants near Building C-400 using electrical resistance heating. Moreover, PGDP is working with regulators and stakeholders to comprehensively address soil and groundwater contamination, and to develop a risk-based end-state goal for the site (DOE, 2005). A key aspect of the broad long-term environmental management of the site is collecting data to help understand, mitigate and assure that risks from the existing groundwater contaminant plumes are acceptable and that the site will achieve regulatory goals in an acceptable time frame. Identification of the important natural attenuation mechanisms occurring in the PGDP TCE plumes and documentation of degradation rates are integral to this effort.

The subsurface at PGDP (Figure 5) has three relevant hydrogeologic zones: 1) the Upper Continental Recharge System (UCRS; about 0-65 feet deep); 2) the Regional Gravel Aquifer (RGA; about 65-87 feet deep); and 3) the underlying McNairy Formation (McNairy; greater than about 87 feet deep). Contaminants, primarily TCE and ${ }^{99}$ Tc, have been detected in all three zones. As shown in Figure 5, however, the dissolved phase plume is transported by groundwater flow primarily in the relatively permeable RGA after release from the source zone. Spatially, three major plumes -- Northwest, Northeast, and Southwest -- have been identified beneath PGDP based on contaminants, migration patterns and plume origins. 


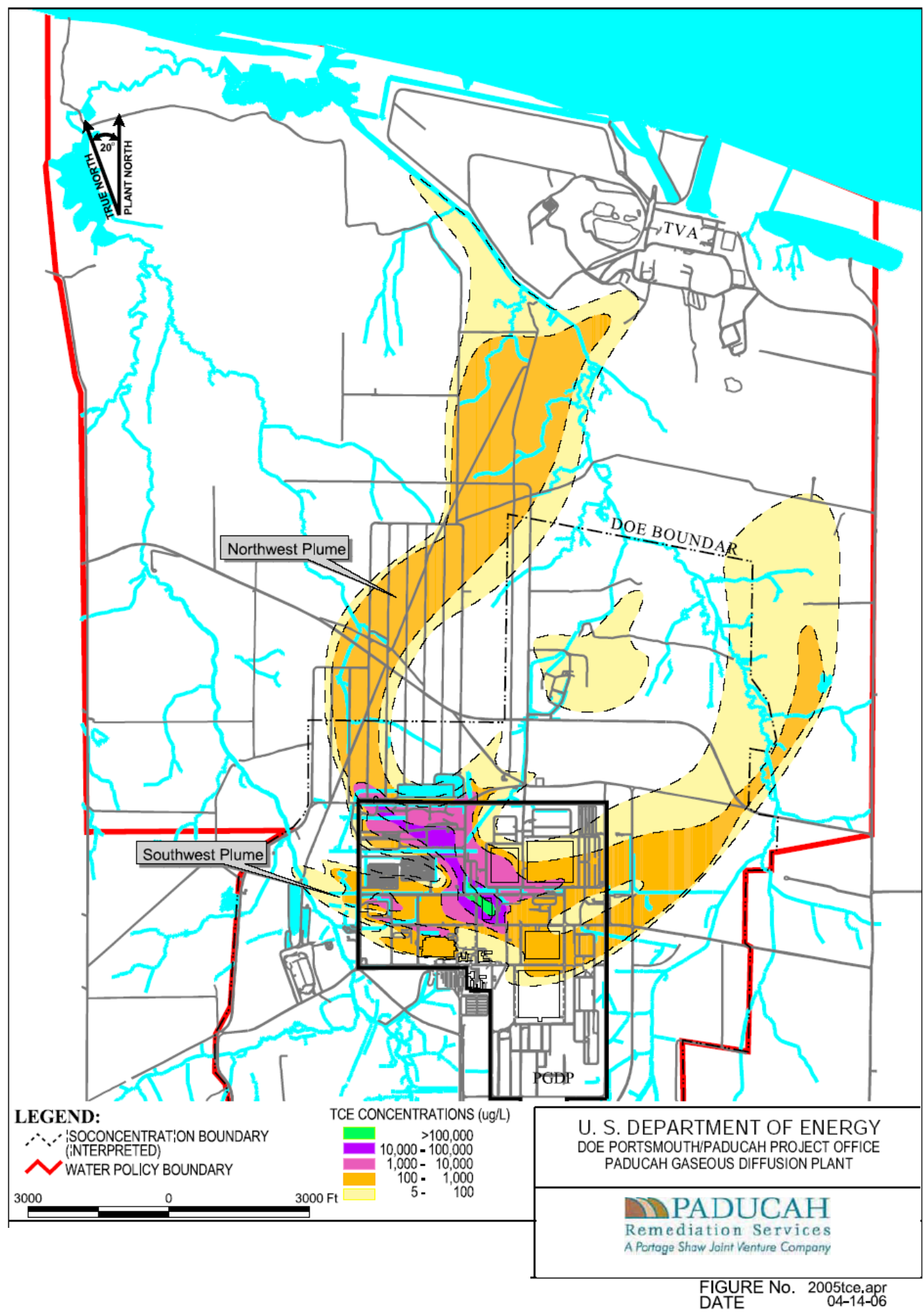

Figure 3. Calendar Year 2005 TCE Plumes in the RGA Underlying PGDP (PRS, 2007) 


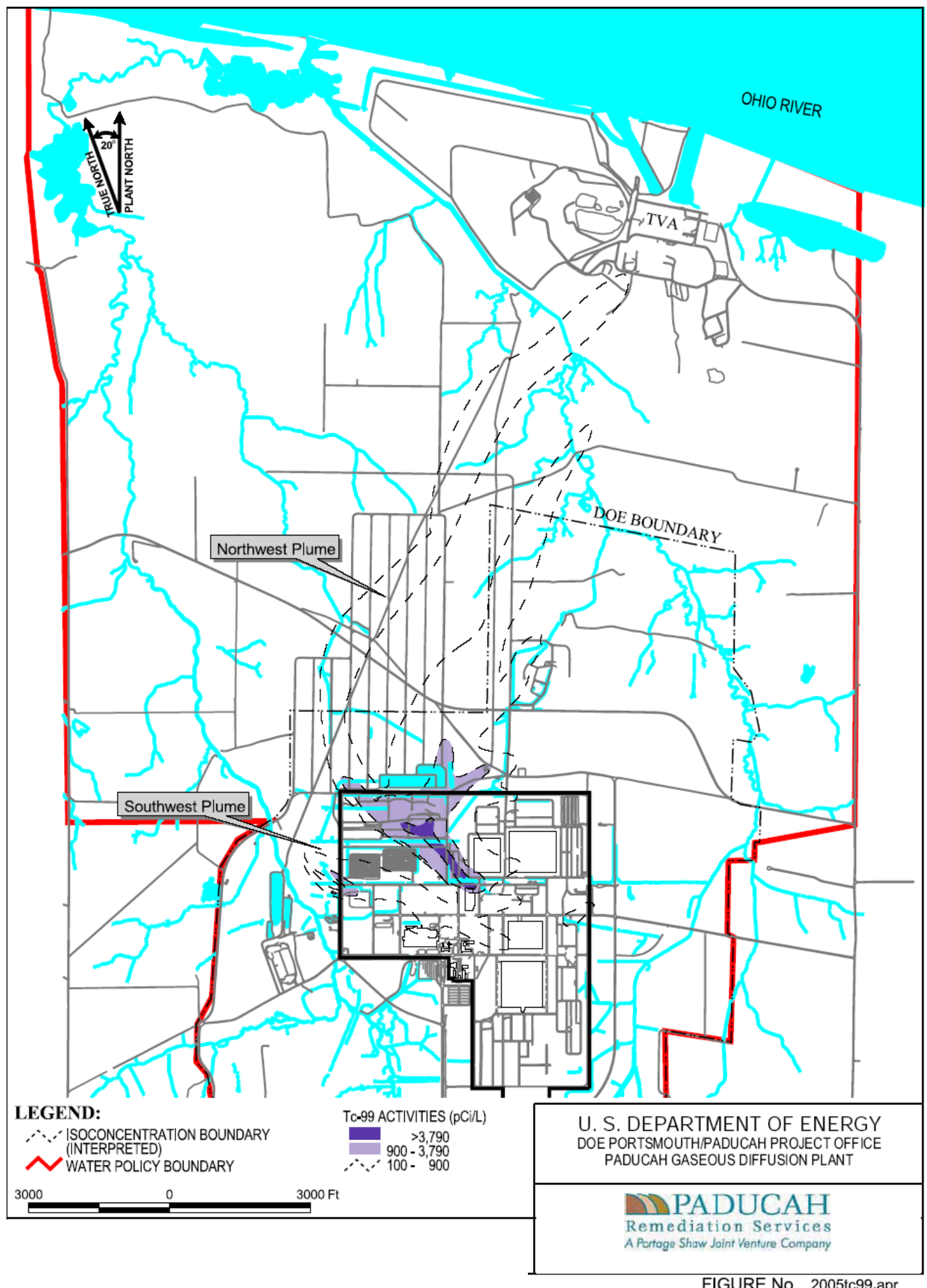

FIGURE No. $\begin{array}{r}2005 \text { tc99.apr } \\ \text { 03-24-06 }\end{array}$
DATE

Figure 4. Calendar Year $2005{ }^{99}$ Tc Plumes in the RGA Underlying PGDP (PRS, 2007) 


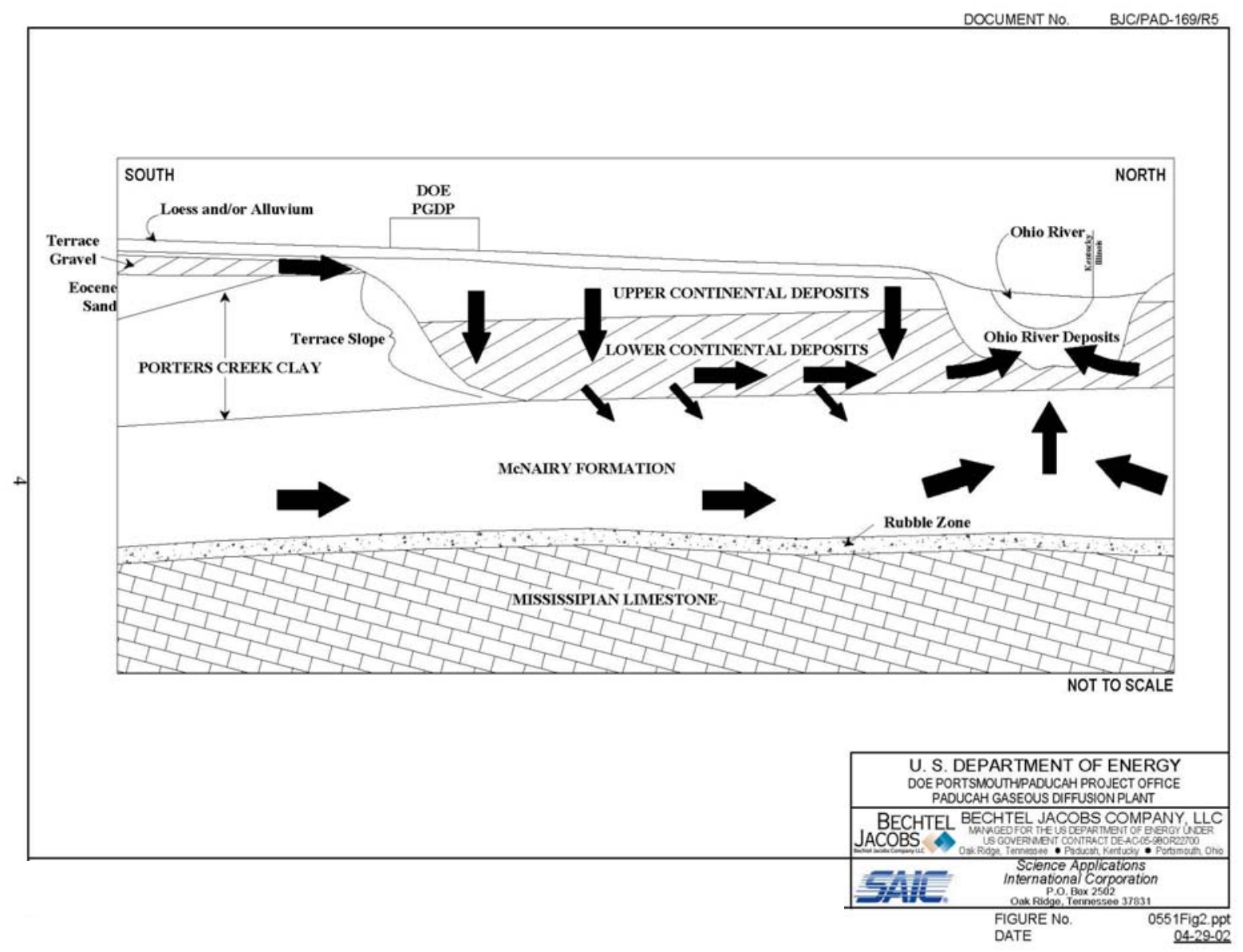

Figure 5. PGDP geologic/hydrogeologic conceptual model. The Upper continental deposits represent the "Upper Coninental Recharge System" or UCRS, and the Lower Continental Deposits represent the Regional Gravel Aquifer or RGA (PRS, 2007). 
In the report, Evaluation of Natural Attenuation Processes for Trichloroethylene and Technetium-99 in the Northwest Plume at the Paducah Gaseous Diffusion Plant, Paducah, Kentucky, Clausen et al. (1997) provided an overview of RGA geochemistry and provided an early evaluation of TCE biodegradation. Clausen et al. (1997) concluded that degradation was occurring, that the degradation rates were relatively slow compared to literature values for reductive dechlorination with an estimated TCE half-life at PGDP in the range of 9.4 to 26.7 years, and that reductive dechlorination was not a substantive contributor to attenuation/degradation in this plume.

The spatial and temporal concentration data from the Northwest Plume have been periodically re-evaluated by subsequent investigators. All of the efforts are based on field-scale observations of the structure of the plume centerline concentration and a comparison of the behavior of TCE to a relatively conservative co-contaminant, ${ }^{99} \mathrm{Tc}$, using interpretive methods recommended by EPA (1998). All of the studies performed in the Northwest Plume have confirmed Clausen's initial findings that TCE appears to be degrading as it migrates through the PGDP groundwater system and that the half life based on a first order decay model calculation is nominally in the range of 9 to 25 years.

Emerging data from the literature suggest that the apparent degradation rates observed at PGDP are similar to those measured at other sites that have similar aerobic geochemistry. For example, at INL Test Area North (TAN), dilution-corrected field scale plume data suggest that TCE is attenuating relative to two internal tracers with a half-life of 9 to 21 years. Molecular and biological assays, as well as laboratory microcosms using water from this site confirmed that aerobic cometabolism is the probable degradation mechanism and yielded an independent halflife estimate of 22 years (Lee et al., 2005).

DOE and DOD are currently funding research to determine the potential utility of broader application of molecular and biological assays for aerobic cometabolism. Preliminary data from plumes underlying the PGDP (this study), Sandia National Laboratory, Hill Air Force Base, Tinker Air Force Base, and the Savannah River Site suggest that cometabolism plays a role in attenuating large aerobic plumes. Similar to PGDP, the plume structure at these diverse contaminated sites are consistent with degradation at the approximate rates observed at TAN.

\section{Enzyme activity probe study and related efforts}

An assessment of the potential for aerobic cometabolism was conducted for the Northwest Plume located within RGA at PGDP. This assessment was based on EAPs supplemented by multiple lines of supporting evidence (DNA, geochemistry, CSIA, etc.) for 12 RGA wells that are located along the plume centerline and two control wells located outside the footprint of the Northwest Plume (see Figure 6). The study is a central activity in a larger program to understand the fate and transport of TCE in PGDP groundwater. The TCE Fate and Transport Project scoping team (Project Team) consists of representatives from Paducah Remediation Services (PRS) and Portage Environmental, the Commonwealth of Kentucky Division of Waste Management, EPA Agency Region 4 in Atlanta GA, and the Kentucky Research Consortium for Energy and Environment (KRCEE). This team was supported by representatives of the EPA Robert S. Kerr Laboratory in Ada OK, the University of Oklahoma, Savannah River National Laboratory 
(SRNL), North Wind Inc. and others. The DOE Paducah Portsmouth Project Office (PPPO) and EM sponsored the efforts of the team. All of the individuals and organizations contributed to the planning and execution of this research and worked to identify the wells used in the Northwest Plume, and established the research data quality objectives (DQOs)..

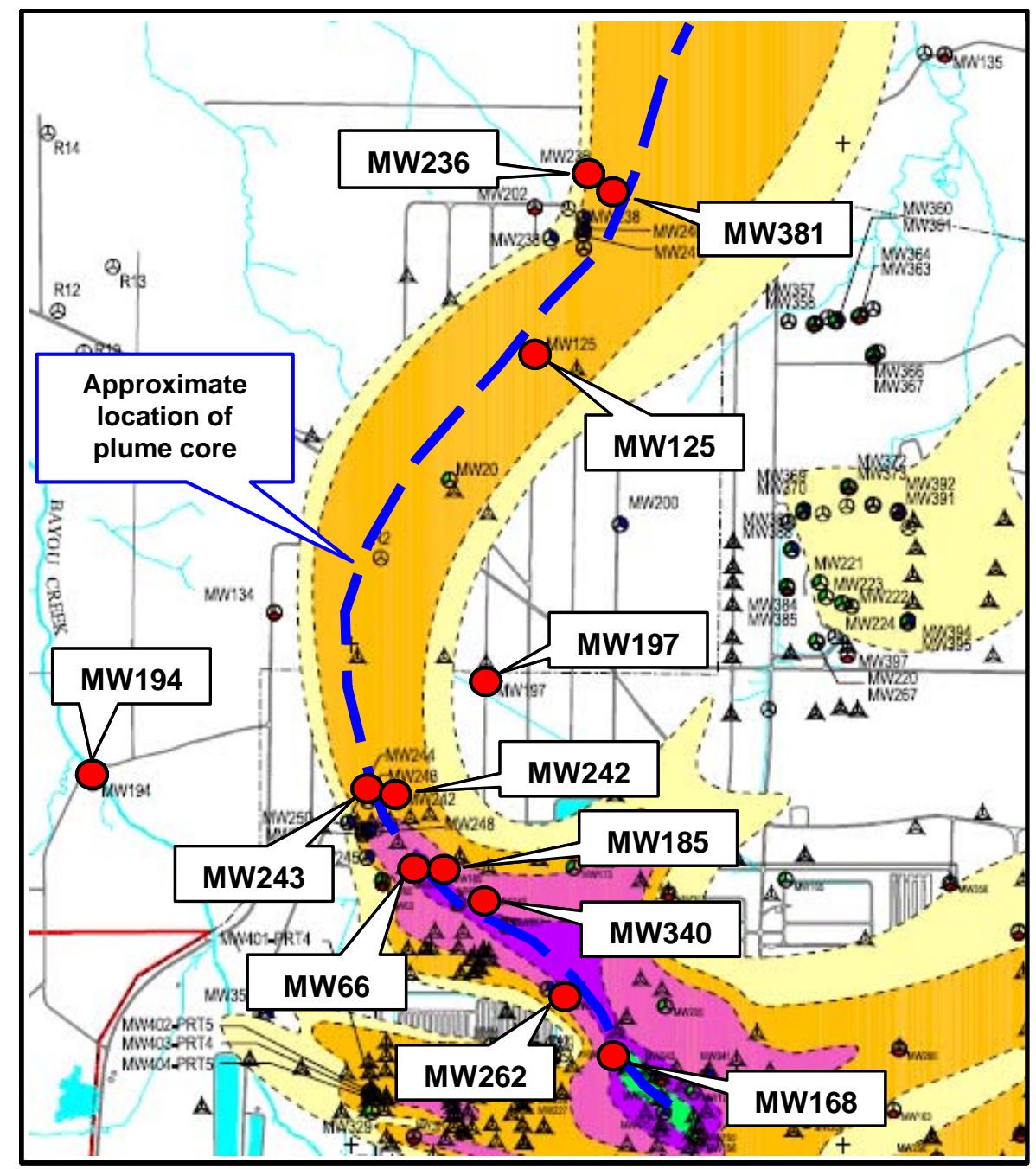

Figure 6. Wells sampled to support the assessment of attenuation processes in the Northwest Plume, PGDP

The Project Team specified the goals of this research effort, as presented in the document: TCE Fate \& Transport Project, Evaluation of Aerobic Degradation, Enzyme Activity Probe Sampling Scoping Document (KRCEE, 2007). The following questions are summarized from the report:

1. Is aerobic biodegradation, cometabolism, employing an appropriate oxygenase enzyme, occurring in the RGA plumes?

2. Are the bacteria present in sufficient numbers to impact the plumes?

3. Are conditions in the RGA conducive for ongoing and sustainable aerobic biodegradation?

4. If aerobic biodegradation is occurring, what is the rate?

5. Is the calculated biodegradation rate or rates qualitatively supported by literature values? 
Each of these main questions was expanded and then used to generate a set of decision/estimation statements to be addressed in this research. These decision/estimation statements are as follows:

Decision / Estimation Statement \#1. Based on use of specific oxygenase probes, determine whether bacteria capable of aerobically biodegrading TCE are present and therefore require an estimation of their impact on the plumes or recommend that other mechanisms of TCE degradation/attenuation be evaluated.

Decisions / Estimation Statement \#2. Based on the use of stable carbon isotope (SCI) fractionation tests, determine whether SCI supports the occurrence of aerobic biodegradation process or other biotic/abiotic degradation processes.

Decision / Estimation Statement \#3. Estimate whether the distribution and number of bacteria are sufficient to significantly biodegrade TCE in RGA groundwater. If the distribution and number of microorganisms are sufficient to biodegrade TCE in RGA groundwater, determine whether biodegradation is sustainable. If it is determined that biodegradation is not sustainable, recommend that other mechanisms of TCE degradation/ attenuation be evaluated.

Decision / Estimation Statement \#4. Determine whether conditions including, but not limited to, the existence of a bioavailable and sustainable substrate in the RGA are conducive for ongoing and sustainable aerobic biodegradation of TCE. If conditions are determined to be ongoing and sustainable, conduct an evaluation of the biodegradation rate using a multiple lines of evidence approach. If conducive conditions are not determined to be present, recommend that other mechanisms of TCE degradation/attenuation be evaluated.

Decision / Estimation Statement \#5. Based upon a comparison to the calculated biodegradation rate or range of rates to values in the literature, either accept the calculated rate(s) for use in future fate-and-transport modeling or access the team's confidence in the unsupported results.

The decision/estimation statements were further expanded and amplified by the Project Team to include specific quantitative decision rules and criteria. These criteria will be used as the initial basis for the conclusions from the study. Any modifications or deviations from these criteria, and the basis for the modification, are described in the report.

The Northwest Plume at PGDP was identified by the Project Team as the focus of sampling and characterization activities. Wells within the Northwest Plume were previously used for firstorder, rate-constant tracer normalization analyses. These wells also offer the greatest number and areal distribution of RGA monitoring wells at PGDP, compared to the Northeast and Southwest Plumes. Sampling of suitable Northwest Plume RGA wells is intended to provide a profile of potential aerobic microbial degradation along the plume axis (Figure 7). 


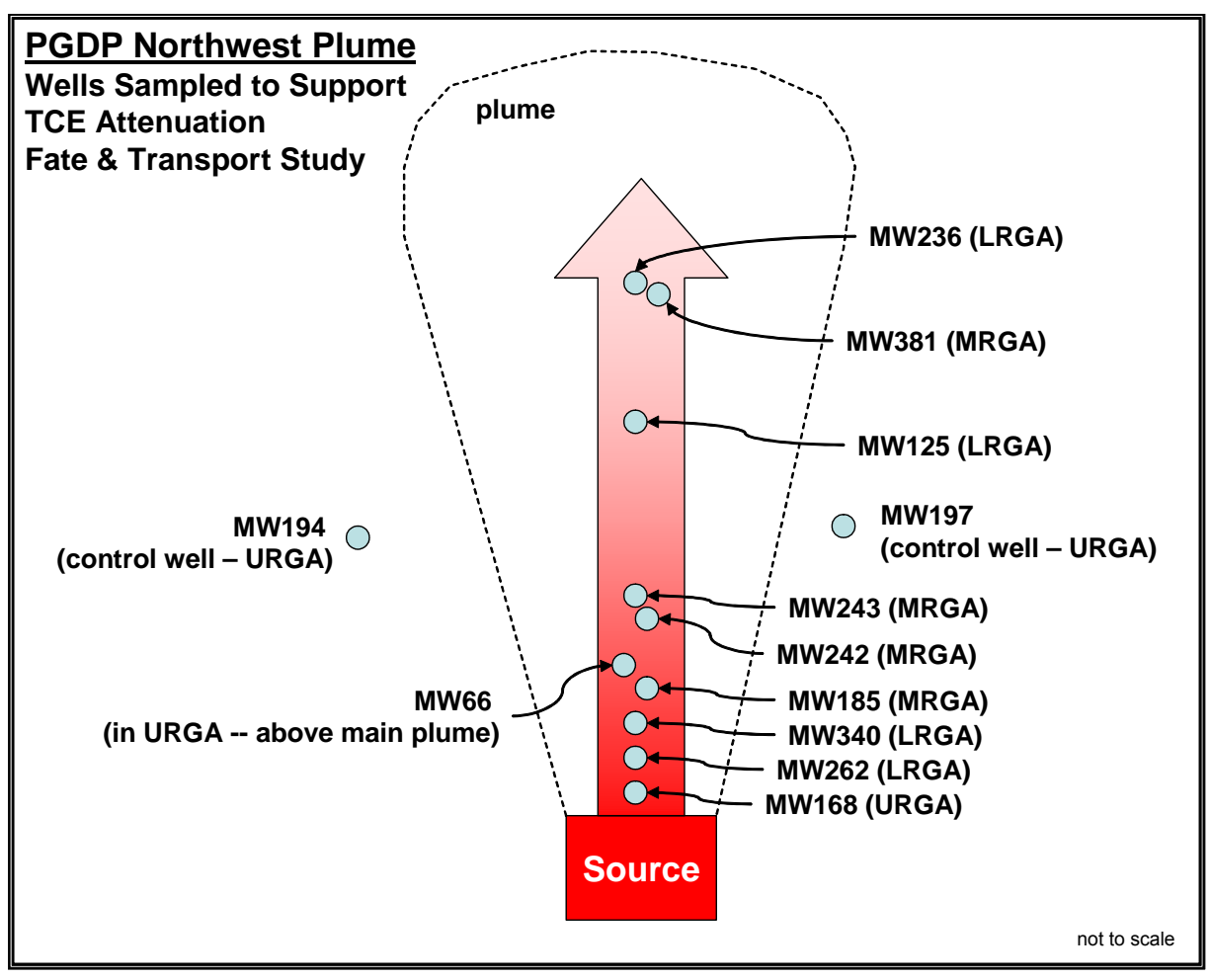

Figure 7. Schematic diagram of PGDP NW Plume and the wells selected by the Project Team

The factors considered for identification of monitoring wells suited for this study included:

1) Relative position of monitoring wells to the centerline of the Northwest Plume

2) Relative location of monitoring wells in relation to TCE sources, wells representing a range from high to low TCE concentration, and control wells located outside the plume

3) Relative location of candidate wells to one another

4) Screened interval of wells to represent the vertical distribution and flow lines

5) General geochemical characteristics of each well including alkalinity, $\mathrm{pH}$, dissolved oxygen, and TCE concentration

Other criteria considered for project well selection included: TCE trend analysis, scheduled well sampling dates, and costs for additional analytes, or special sampling. Geochemical characteristics of the wells were evaluated relative to each parameter's potential to support or inhibit microbial populations capable of TCE degradation. Foremost, the Project Team selected the well network to identify the presence and extent of aerobic cometabolism degradation processes in the Plume. The Team agreed that the well network was reasonable for these purposes, and that it would support the DQO process.

The data presented throughout this report are categorized by vertical zone within the RGA: the upper RGA (URGA) with wells screened between 47-68 feet below ground surface (bgs), the middle RGA (MRGA) with wells screened between 65-76 feet bgs, and the lower RGA (LRGA) with wells screened between 69-95 feet bgs.

This report summarizes the methods (Section 2), results (Section 3), and significance (Section 4) of this EAP assessment and related geochemical testing. 


\section{Methods}

\section{Enzyme Activity Probes}

\section{Toluene Enzyme Activity Determination}

A schematic of the steps in the toluene enzyme activity determination is shown in Figure 8. Note that there are three distinct toluene enzyme probes and a separate filter was used for each. Thus, the toluene enzyme activity determinations for each groundwater sample required a minimum of three filters (each probe analysis is performed on three independent samples such that statistical significance can be obtained). Each of these filters was subject to the process shown in Figure 8 using the appropriate compound as the EAP in step II. Details of the various steps in the toluene enzyme activity determination are described and expanded below.

Groundwater (10 mL) was vacuum filtered onto $0.22 \mu \mathrm{m}, 25 \mathrm{~mm}$ diameter, black, polycarbonate filters (Figure 8, step I). Once the vacuum was released, $1 \mathrm{~mL}$ of $5 \mathrm{mM}$ of an enzyme activitydependent probe (phenylacetylene, trans-cinnamonitrile, 3-hydroxyphenylacetylene) in $40 \mathrm{mM}$ phosphate buffer was pipetted onto the filter (step II). After fifteen minutes (step III), the vacuum was reapplied to remove the probe/buffer solution (step IV). Next, DAPI (4,6diamidino-phenylindole) was added to the filter surface in order to obtain a total cell count. After a few minutes, the DAPI solution was removed from the filter surface, which was then washed with $1 \mathrm{~mL}$ of buffer solution. The filter was allowed to air dry and then mounted on a glass microscope slide with non-fluorescent immersion oil and a cover slip. The filters were examined for fluorescent cells by epifluorescent microscopy using a 100X oil-immersion fluorescent objective and a filter set for blue excitation wavelengths (step V). Probe response was visualized on a Leica DMRB fluorescence microscope equipped with a PL APO (plan apochromatic) 100x 1.30 oil objective (Leica Microsystems, Inc., Bannockburn, IL, USA). An XF34 longpass orange-red filter set was used (excitation $535 \pm 17.5 \mathrm{~nm}$, dichroic mirror 570nm, emission 590nm) (Omega Optical, Inc., Brattleboro, VT, USA). The imaging system used included a Spot cooled color digital camera and commercial (Spot version 3.0.4 for Windows) imaging software (Diagnostic Instruments, Inc., Sterling Heights, MI, USA).

The data were processed twice, first qualitatively and then quantitatively, to support interpretation of the potential significance of cometabolism in the original wells. In the qualitative processing, approximately 5-10 random visual fields on the slide were rapidly examined to determine if labeled (fluorescent) cells were present; scores were recorded as positive if more than 5-7 fluorescent cells were visualized. However, if most of the fields contained minimal activity (1-2 total cells or no fluorescence), then the sample was qualitatively identified as negative (-) for activity of enzymes that converted that particular probe. The quantitative processing included collecting 20 random fields for at least three separate prepared slides (or an appropriate number of fields to count a minimum 200 total cells) with the microscope-attached digital camera. Each image was then processed using software to count the labeled (fluorescent) cells and estimate the activity in the original sample in standard reporting units (cells/mL). A minimum of 1 image of every 10 images captured was also counted manually by the experimenter and compared with the counts collected and recorded by the software. 


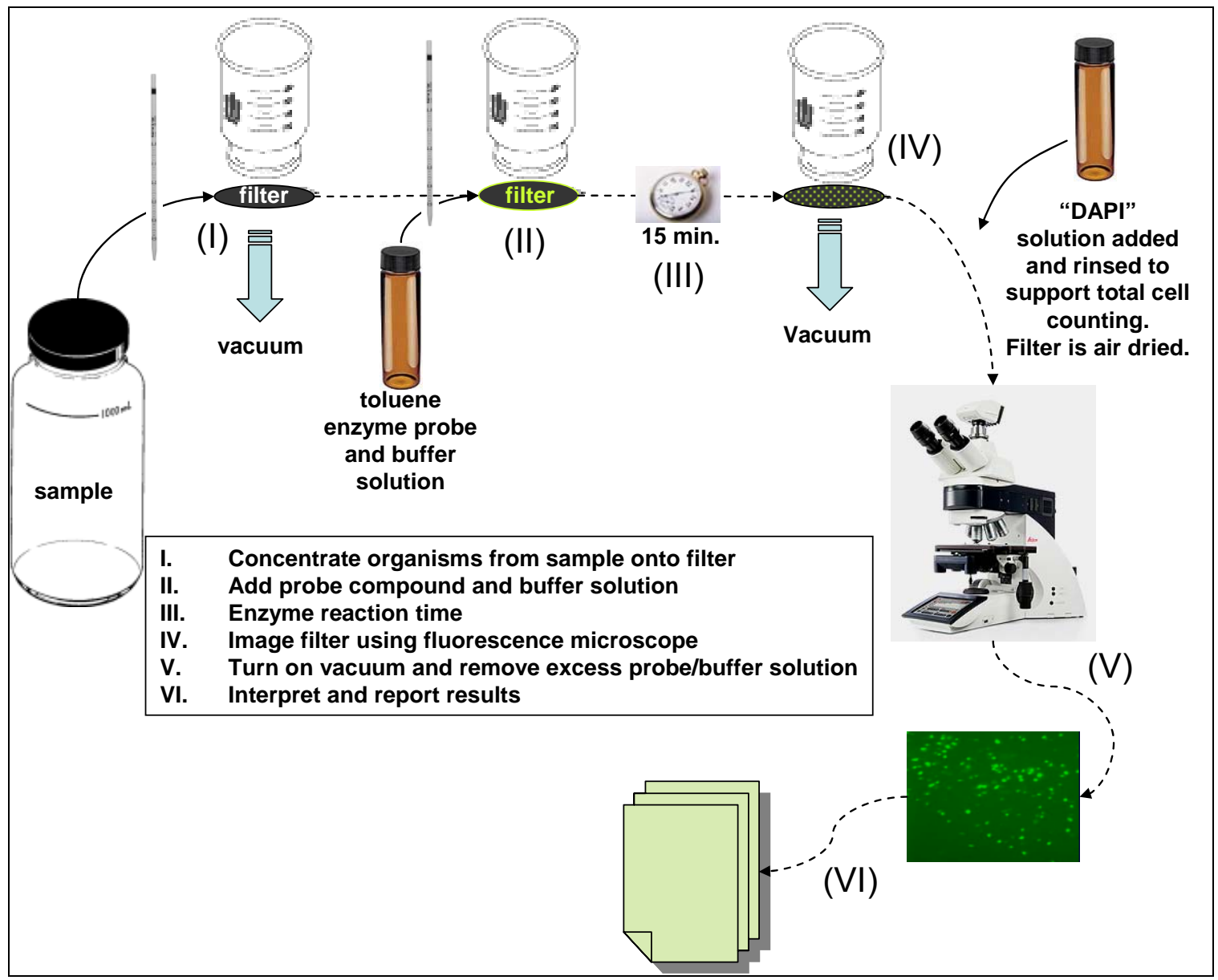

Figure 8. Schematic diagram of the steps in toluene enzyme activity determinations

For interpretation of the quantitative measurements of toluene probes, the DQO specified that those samples with more than $10^{3}$ cells/mL would be identified as positive $(+)$ for significant cometabolic activity and samples with less than $10^{3}$ cells/mL would be identified as negative (-). Based on comparison to the qualitative measurements, these initial quantitative criteria were determined to be too low. A screening level of $10^{3}$ cells $/ \mathrm{mL}$ results in identifying all the samples as positive, even those that were determined to be negative in the qualitative examination. One of the goals of the national DOE applied research effort is development and refinement of quantitative criteria to support the use of EAPs. Examination of the PGDP data, in combinations with data from several other sites (Savannah River Site, Hill Air Force Base, Tinker Air Force Base, etc.) indicated that a more defensible criterion for a positive determination is approximately $8 \times 10^{3}$ cells $/ \mathrm{mL}$. Based on this information, we have analyzed and presented the data in three bins: $<3 \times 10^{3}$ cells $/ \mathrm{mL}=$ low activity, $3 \times 10^{3}$ to $8 \times 10^{3}$ cells $/ \mathrm{mL}=$ moderate activity, and $>8 \times 10^{3}$ cells $/ \mathrm{mL}=$ high activity. This approach is methodologically consistent with the DQO but provides an assessment that was deemed by the investigators to be a better metric of the potential significance of cometabolism. Notably, the refined significance criteria developed herein, $8 \times 10^{3}$ cells $/ \mathrm{mL}$ for high activity, is similar to cell activity levels $\left(1 \times 10^{4}\right.$ cells $\left./ \mathrm{mL}\right)$ recently documented by Lu et al. as a screening level for significant populations of Dehalococcoides spp. 
to support reasonable rates of anaerobic degradation. While the results of Lu et al. and the screening values we determined for this effort are not precisely analogous ( $\mathrm{Lu}$ et al. based the determination on anaerobic degradation, a degradation rate of 0.3 year $^{-1}$, and diverse scientific literature data for many sites and from lab studies), the independent development of similar screening levels is encouraging and provides further justification for refining (increasing) the initial criteria in the DQO.

\section{sMMO Enzyme Activity Determination}

A schematic of the steps in the sMMO enzyme activity determination is shown in Figure 9. Due to the nature of the sMMO enzyme and the solubility of the fluorescent product formed from the sMMO probe coumarin (7-hydroxy-coumarin), fluorescence from a positive probe is found predominantly in the solution rather than associated with individual cells. In this particular determination, the fluorescent product is measured in the bulk solution rather than by imaging labeled cells. The results for the sMMO probe and the estimates of significance are based on overall solution fluorescence. Because the results for the sMMO probe are not directly related to the number of organisms that are actively expressing the enzyme, and they are not reported in units such as cells/mL (or percent of population), all of these results will be reported as qualitative. Details of the various steps in the sMMO enzyme activity determination are described and expanded below.

Whole water (unaltered) groundwater samples (10 mL each) were filtered onto 25mm Supor filters (Figure 9, step I). These filters were placed into separate glass Petri plates (step II), 1mL of $5 \mathrm{mM}$ coumarin solution in phosphate buffer was pipetted onto each filter (step III), and the filters were incubated for 10 minutes at room temperature (step IV). Following the incubation, each plate was positioned at a $35^{\circ}$ angle, and phosphate buffer was used to wash the product from each filter. The buffer was re-pipetted over the filter 6 times to ensure quantitative recovery of the product (step V). Solution fluorescence was determined (excitation wavelength $338 \mathrm{~nm}$, emission wavelength $450 \mathrm{~nm}$ ) using a Hitachi F-2000 fluorescence spectrophotometer (Hitachi, Tokyo, Japan), with a quartz cuvette of $1 \mathrm{~cm}$ path length (Amersham). Ten replicate fluorescent scans were performed for each of the samples (step VI). 


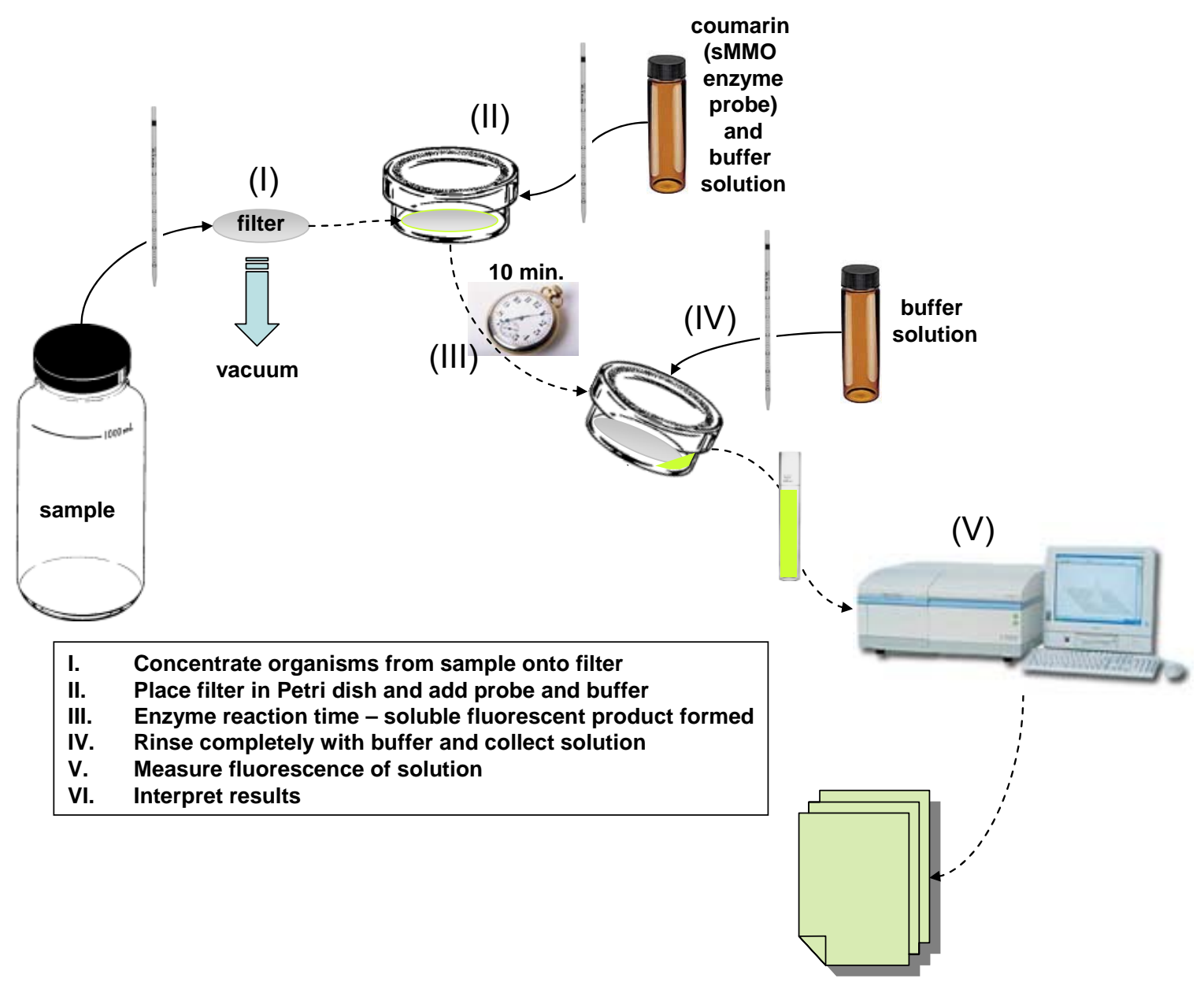

Figure 9. Schematic diagram of the steps in sMMO enzyme activity determinations

Inhibition assays to confirm sMMO and toluene enzyme activity results -- To verify the dependence of product formation on the activity of the targeted oxygenases rather than the activity of other enzymes, select inhibitors were added to the samples and then analyzed for target enzyme activity. Groundwater samples $(5 \mathrm{~mL})$ were placed in $10-\mathrm{mL}$ serum vials, and acetylene (sMMO inhibitor) was added as a vapor to each. Vials were sealed and incubated for 30 minutes at room temperature. To verify the reaction of groundwater with various toluene/aromatic probes, 1-pentyne (3.5\%) was used as selective inhibitor for these pathways (method described in Keener et al., 2001). After treatment by the inhibitors, samples were filtered and analyzed with enzyme probes as described previously. 
DNA Extraction and PCR Amplification - "DNA Control Study"

DNA was isolated from the cells trapped on filters. DNA extraction was performed using both Bio 101 and the MoBio UltraClean Soil DNA kit as described by the manufacturers. Two kits were used to ensure that biases associated with one kit or another did not provide a false positive for the presence of the gene of interest. The samples consistently yielded high-quality bacterial DNA, based on gel electrophoresis. DNA extraction and PCR amplifications were used to confirm that relevant DNA was present in the samples and provide a quality assurance and verification step to support the interpretation of the enzyme activity determinations.

PCR amplification reactions were performed in $50 \mu \mathrm{L}$ (total volume) reaction mixtures in $0.2 \mathrm{~mL}$ thin-walled tubes using a DNA thermocycler. The PCR experiments were performed using the Taq PCR Core kit from Qiagen. The PCR conditions for the toluene oxygenase primers were as stated in Baldwin et al. (2003). The PCR primers were designated: RMO-F/R, which amplify the toluene-3 and -4-monooxygenase genes, TOD-F/R which amplifies the toluene 2,3-dioxygenase gene, and PHE-F/R which amplifies the toluene-2, -3, -4-monooxygenase genes (Baldwin et al., 2003). PCR amplified DNA was visualized using a $2 \%(\mathrm{w} / \mathrm{v})$ agarose gel electrophoresis with TBE buffer at $75 \mathrm{~V}$ for 1.5 hours.

\section{Supplementary Microbial Diversity “T-RFLP” Study}

Terminal restriction fragment length polymorphism (T-RFLP) was also performed on all 12 of the groundwater samples collected from the PGDP Northwest Plume. T-RFLP is a DNA (or RNA) fingerprinting technique that provides a broad look at the diversity of the Bacterial and/or Archaeal communities in a sample (Marsh et al., 1999; 2000; Dunbar et al., 2000; 2001; Osborn et al., 2000; Blackwood et al., 2003 ). T-RFLP is a relatively straightforward technique that relies on the presence of the $16 \mathrm{~S}$ rDNA gene, which has been shown to be present in all known organisms (Woese, 1975). Briefly, DNA was amplified from the samples as described previously. PCR amplification of DNA from the samples was performed with 16S universal primers 8F and 907R with the forward primer also carrying a fluorescent label (FAM). Following the PCR, the amplified DNA was subjected to a restriction enzyme digest with Msp I that cuts the DNA fragments into pieces based on the identification of unique cut sites; in this case, Msp I cuts the DNA each time it "finds” the sequence CCGG. Each organism present in the sample (extracted directly from PGDP groundwater) theoretically has a unique sequence and as such would produce unique size fragments when digested with MSP I. Once digested (DNA cut into many small fragments), the fluorescently-labeled end fragments were run through a DNA sequencer to determine the length (base pairs, bp) and abundance (fluorescence) of each of the fluorescent fragments produced from steps one and two (Figure 10).

The fingerprint resulting from a T-RFLP analysis has been shown to be a powerful technique for identifying differences in population structure and determining the overall diversity of a population. T-RFLP fingerprints can easily be compared across temporal or spatial scales (for example: Dunbar et al., 2000; Osborn et al., 2000; Scala and Kerkhof, 2000; Mummey and Stahl, 2003). It should be noted, however, that because an organism can produce more than one unique fragment, multiple organisms could theoretically produce the same size fragment, and analysis of the resulting fingerprints needs to consider these potential complexities. 
For the particular concern at PGDP, T-RFLP was proposed as a simple approach to identify the potential contribution of biofilm (i.e. biofouling) communities to the total microbial makeup of the groundwater samples collected for enzyme probe analysis. It was thought that biofilm communities would have a distinct makeup based on the microbial metabolisms present in those biofilms (anaerobic, sessile) versus those communities that would dominate aerobic groundwater, indicative of the plume.

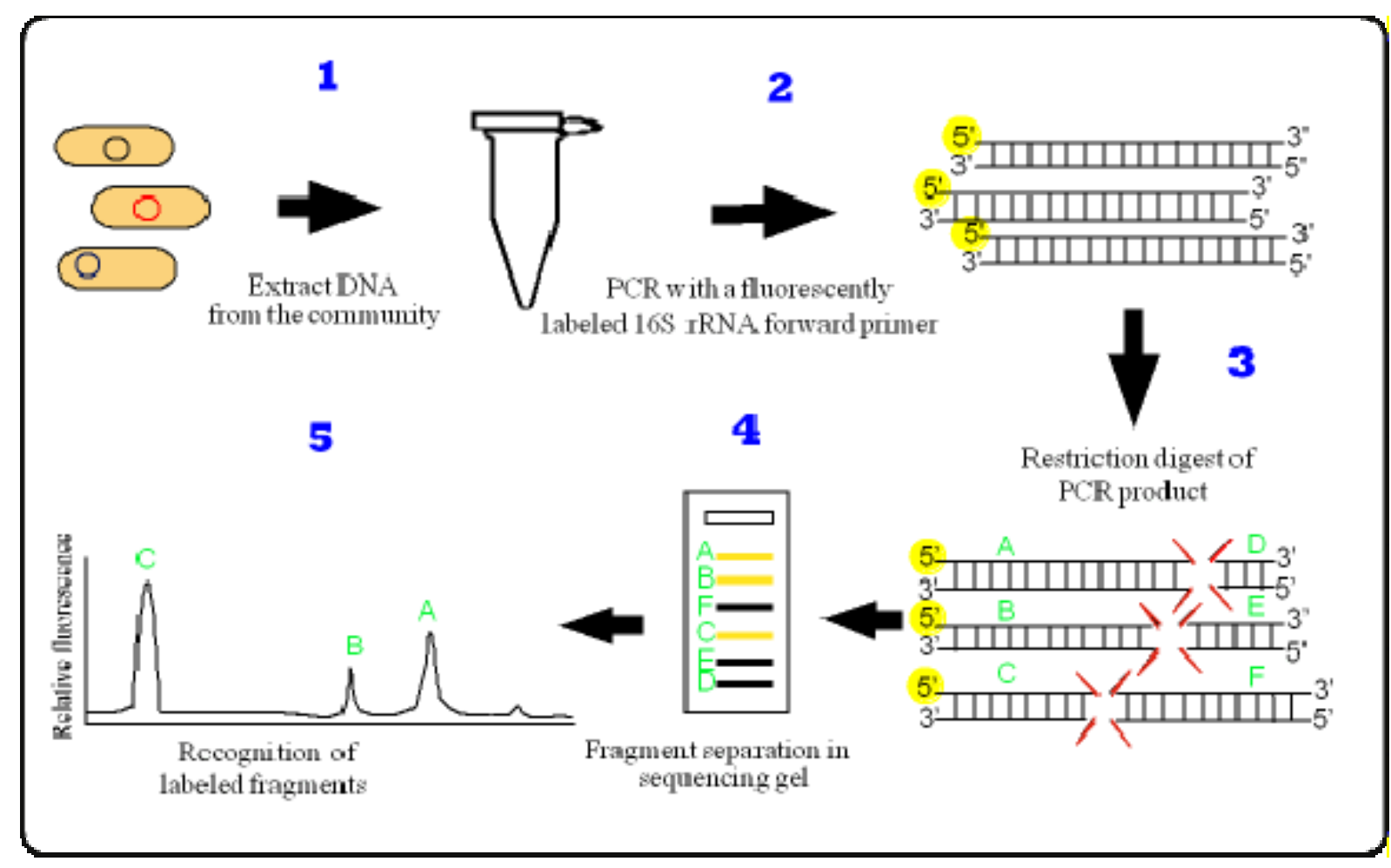

Figure 10. T-RFLP schematic, copied with permission from the Center for Microbial Ecology, Michigan State University.

\section{Geochemical Parameters}

Supporting geochemical measurements were collected during this study to determine the impacts of environmental conditions on key aspects of the microbial ecology. The data collected include the traditional "master variables" such as $\mathrm{pH}$ and oxidation-reduction potential (ORP), as well as related parameters such as dissolved oxygen and various cations and anions. The samples for geochemistry and the molecular and biological assays were collected by the onsite environmental sampling crew. Sampling, measurement of field parameters, and handling/measurement of geochemical parameters in the laboratory were all performed using the existing site infrastructure (packaging, shipping, QA, data management, etc.) according to the Paducah Site Environmental Monitoring Plan (BJC, 2004). 
The geochemical and field parameters measured to support this effort are shown in Table 1 along with the nominal detection limits. The most significant results (i.e., detectable and potentially diagnostic) are indicated in bold in Table 1 and are reported in the following section. Two geochemical sampling events were conducted to support this study, a primary sampling (May 2007) in which all of the listed parameters were measured, and a follow-up sampling (December 2007) in which a subset of the listed parameters was measured. All of the supporting geochemistry data are provided in Appendix A.

Table 1. Supporting Geochemical and Field Measurements

\begin{tabular}{|c|c|c|}
\hline Parameter & $\begin{array}{c}\text { Detection } \\
\text { Limit * }\end{array}$ & Units \\
\hline Barometric Pressure & -- & in. $/ \mathrm{Hg}$ \\
\hline Depth to Water & -- & $\mathrm{ft}$ \\
\hline Dissolved Oxygen & -- & $\mathrm{mg} / \mathrm{L}$ \\
\hline Oxidation-Reduction Potential & -- & $\mathrm{mV}$ \\
\hline $\mathrm{pH}$ & -- & Std Unit \\
\hline Temperature & -- & $\operatorname{deg} \mathrm{F}$ \\
\hline Conductivity & -- & umho/cm \\
\hline Turbidity & -- & NTU \\
\hline chloride & 2 & $\mathrm{mg} / \mathrm{L}$ \\
\hline nitrate & 4.4 & $\mathrm{mg} / \mathrm{L}$ \\
\hline sulfate & 2 & $\mathrm{mg} / \mathrm{L}$ \\
\hline iron (II) & 0.02 & $\mathrm{mg} / \mathrm{L}$ \\
\hline dissolved organic carbon & 1 & $\mathrm{mg} / \mathrm{L}$ \\
\hline total organic carbon & 1 & $\mathrm{mg} / \mathrm{L}$ \\
\hline alkalinity as $\mathrm{CaCO}_{3}$ & 10 & $\mathrm{mg} / \mathrm{L}$ \\
\hline orthophosphate & 3.1 & $\mathrm{mg} / \mathrm{L}$ \\
\hline phosphate as P & 1 & $\mathrm{mg} / \mathrm{L}$ \\
\hline calcium & 1 & $\mathrm{mg} / \mathrm{L}$ \\
\hline dissolved copper & 0.025 & $\mathrm{mg} / \mathrm{L}$ \\
\hline total copper & 0.025 & $\mathrm{mg} / \mathrm{L}$ \\
\hline magnesium & 0.025 & $\mathrm{mg} / \mathrm{L}$ \\
\hline potassium & 2 & $\mathrm{mg} / \mathrm{L}$ \\
\hline sodium & 2 & $\mathrm{mg} / \mathrm{L}$ \\
\hline carbon dioxide & 10 & $\mathrm{mg} / \mathrm{L}$ \\
\hline bicarbonate as $\mathrm{CaCO}_{3}$ & 10 & $\mathrm{mg} / \mathrm{L}$ \\
\hline carbonate as $\mathrm{CaCO}_{3}$ & 10 & $\mathrm{mg} / \mathrm{L}$ \\
\hline Technetium-99 & 17 & $\mathrm{pCi} / \mathrm{L}$ \\
\hline & & \\
\hline
\end{tabular}

\begin{tabular}{|c|c|c|}
\hline Parameter & $\begin{array}{c}\text { Detection } \\
\text { Limit * }\end{array}$ & Units \\
\hline 1,1,1-Trichloroethane & 5 & $\mathrm{ug} / \mathrm{L}$ \\
\hline 1,1,2,2-Tetrachloroethane & 5 & $\mathrm{ug} / \mathrm{L}$ \\
\hline 1,1,2-Trichloroethane & 5 & $\mathrm{ug} / \mathrm{L}$ \\
\hline 1,1-Dichloroethane & 1 & ug/L \\
\hline 1,1-Dichloroethene & 1 & $\mathrm{ug} / \mathrm{L}$ \\
\hline 1,2-Dichloroethane & 5 & $\mathrm{ug} / \mathrm{L}$ \\
\hline 1,2-Dichloropropane & 5 & $\mathrm{ug} / \mathrm{L}$ \\
\hline 1,2-Dimethylbenzene & 5 & $\mathrm{ug} / \mathrm{L}$ \\
\hline 2-Butanone & 10 & ug/L \\
\hline 2-Hexanone & 10 & $\mathrm{ug} / \mathrm{L}$ \\
\hline 4-Methyl-2-pentanone & 10 & $\mathrm{ug} / \mathrm{L}$ \\
\hline Acetone & 10 & ug/L \\
\hline Benzene & 5 & $\mathrm{ug} / \mathrm{L}$ \\
\hline Bromodichloromethane & 5 & $\mathrm{ug} / \mathrm{L}$ \\
\hline Bromoform & 5 & $\mathrm{ug} / \mathrm{L}$ \\
\hline Bromomethane & 5 & $\mathrm{ug} / \mathrm{L}$ \\
\hline Carbon disulfide & 5 & $\mathrm{ug} / \mathrm{L}$ \\
\hline Carbon tetrachloride & 5 & $\mathrm{ug} / \mathrm{L}$ \\
\hline Chlorobenzene & 5 & $\mathrm{ug} / \mathrm{L}$ \\
\hline Chloroethane & 5 & ug/L \\
\hline Chloroform & 5 & ug/L \\
\hline Chloromethane & 5 & $\mathrm{ug} / \mathrm{L}$ \\
\hline cis-1,2-Dichloroethene & 1 & $\mathrm{ug} / \mathrm{L}$ \\
\hline cis-1,3-Dichloropropene & 5 & ug/L \\
\hline Dibromochloromethane & 5 & $\mathrm{ug} / \mathrm{L}$ \\
\hline Dimethylbenzene, Total & 15 & ug/L \\
\hline Ethylbenzene & 5 & $\mathrm{ug} / \mathrm{L}$ \\
\hline meta/para Xylene & 10 & $\mathrm{ug} / \mathrm{L}$ \\
\hline Methylene chloride & 5 & $\mathrm{ug} / \mathrm{L}$ \\
\hline Styrene & 5 & $\mathrm{ug} / \mathrm{L}$ \\
\hline Tetrachloroethene & 5 & $\mathrm{ug} / \mathrm{L}$ \\
\hline Toluene & 5 & $\mathrm{ug} / \mathrm{L}$ \\
\hline trans-1,2-Dichloroethene & 1 & $\mathrm{ug} / \mathrm{L}$ \\
\hline trans-1,3-Dichloropropene & 5 & $\mathrm{ug} / \mathrm{L}$ \\
\hline Trichloroethene & 1 & $\mathrm{ug} / \mathrm{L}$ \\
\hline Vinyl acetate & 10 & ug/L \\
\hline Vinyl chloride & 2 & $\mathrm{ug} / \mathrm{L}$ \\
\hline
\end{tabular}

* Tabulated values are the nominal detection limits. Detection limits for an individual sample may be higher than those listed if a related parameter requires dilution for measurement. 


\section{Compound Specific Isotope Analysis}

The Project Team developed the following questions for CSIA relative to the aerobic biodegradation investigation:

1. Does CSIA support the occurrence of aerobic biodegradation and/or other possible degradation mechanisms?

2. How will CSIA be utilized to characterize sustainability of biodegradation?

3. Can CSIA-independent calculations of the degradation rate be established?

4. Does CSIA allow for the differentiation of biotic and abiotic degradation processes?

To address these questions, nationally-recognized CSIA scientists developed and expanded the questions into decision/estimation statements and associated analytical methods. The CSIA experts included Paul Philp and Tomasz Kuder (University of Oklahoma), John Wilson (EPA), and a focus group from the Project Team that included Ed Winner and Scott Little

(Commonwealth of Kentucky Division of Waste Management), and Steve Hampson (KRCEE). This effort is documented in a separate report. In summary, the CSIA experts and focus group developed the following approach:

1. Calculate apparent extent of removal of TCE compared to a conservative tracer (such as technetium in the PGDP northwest plume:

2. Conduct CSIA for carbon and hydrogen isotopes (note that the current literature supports preliminary application of carbon isotopes for aerobic cometabolism but that more information will be needed to interpret the hydrogen isotopes - the stable hydrogen isotope analyses will be appended to the results when available).

3. Based on analysis of stable carbon isotopes, independently calculate $\mathrm{C} / \mathrm{C}_{0}$ based on changes in the stable carbon isotope ratios $\left(\delta^{13} \mathrm{C}\right)$ in the TCE as the plume moves from upgradient to downgradient in the PGDP Northwest Plume.

4. Perform a similar scoping evaluation for hydrogen isotope ratios.

5. Compare the TCE data $\mathrm{C} / \mathrm{C}_{0}$ to $\mathrm{CSIA} \mathrm{C} / \mathrm{C}_{0}$

6. Calculate $1^{\text {st }}$ order rate constant

7. Apply Decision Rule 4: If the natural logarithm of the value of $\mathrm{C} / \mathrm{C}_{0}$ provided from the analysis of stable isotope ratios is more negative than natural logarithm of the value of $\mathrm{C} / \mathrm{Co}$ as calculated from measured concentrations of TCE as normalized to the measured concentrations of ${ }^{99} \mathrm{Tc}$, or if the natural logarithm of the value of $\mathrm{C} / \mathrm{C}_{0}$ provided from the analysis of stable isotope ratios is no more than a factor of 0.33 more positive than the natural logarithm of the value of $\mathrm{C} / \mathrm{C}_{0}$ as calculated from measured concentrations of TCE as normalized to the measured concentrations of ${ }^{99} \mathrm{Tc}$, the stable isotope analyses will be considered to provide a third line of evidence for MNA processes

8. Apply Decision Rule 5: If the natural logarithm of the value of $\mathrm{C} / \mathrm{C}_{0}$ provided from the analysis of stable isotope ratios is more than a factor of 0.33 more positive than the natural logarithm of the value of $\mathrm{C} / \mathrm{C}_{0}$ as calculated from measured concentrations of TCE as normalized to the measured concentrations of ${ }^{99} \mathrm{Tc}$, the stable isotope analyses will be considered to provide no interpretable information, and will not be used to support a decision.

9. Apply Decision Rule 6: Evaluate uncertainty in the assessment based on sample standard deviations. 


\section{Results}

The results for the enzyme activity assessment, the plume geochemistry, and the compound specific isotopes are presented below.

\section{Enzyme Activity Probes}

The EAP assessment is presented as follows: EAP assays, DNA control study, and T-RFLP study. The EAP assays were conducted in two steps. Initial qualitative EAP results were generated to provide initial evidence for sMMO and toluene activity at the site. The toluene EAPs were then quantified to evaluate the significance of toluene enzyme activity using the methods described in the DQOs. The DNA control study was used to determine if organisms that contain the genes of interest were present at the site. Finally, the T-RFLP evaluation was performed to develop some general conclusions about the community structure in the samples and to assess the "representativeness" of the samples.

Qualitative Toluene and sMMO Enzyme-Activity Probe Results The qualitative toluene EAP data from June 4, 2007 are presented in Table 2. A positive result $(+)$ indicates that the probe was determined to be significant based on a fluorescent signal upon viewing a limited number of fields with an epifluorescent microscope, and it indicates the fluorescence of one or more cells in the typical observed fields from the given groundwater sample. Each probe responds to a primary oxidation pathway (or in a reproducible manner to the various primary pathways). Thus, a single sample can be positive for one, two, or three probes. No single probe provides more or less information regarding the activity or potential activity in a groundwater consortia of bacteria, rather, pathways are stimulated or induced under different conditions. Variable activity, or a positive response in one or more groundwater samples with all of the probes, may be indicative of a diverse metabolic community.

The sMMO results (Table 2) were determined based on solution fluorescence and indicated a fluorescence that was statistically greater than background and control samples. 
Table 2. Preliminary results of EAP analysis in groundwater from monitoring wells at the Northwest Plume at PGDP. A positive mark means activity was determined in the sample.

\begin{tabular}{|c|c|c|c|}
\hline Monitoring Well & $\begin{array}{c}\text { Aquifer } \\
\text { Designation }\end{array}$ & $\begin{array}{l}\text { SMMO probe } \\
\text { Coumarin }\end{array}$ & Toluene probes* \\
\hline MW168 & \multirow{4}{*}{ URGA } & - & - \\
\hline MW66 & & + & ++++ \\
\hline MW194 & & + & +++ \\
\hline MW197 & & - & + \\
\hline MW185 & \multirow{4}{*}{ MRGA } & - & ++ \\
\hline MW242 & & - & - \\
\hline MW243 & & - & - \\
\hline MW381 & & - & ++ \\
\hline MW262 & \multirow{4}{*}{ LRGA } & + & +++ \\
\hline MW340 & & + & + \\
\hline MW236 & & + & +++ \\
\hline MW125 & & + & ++ \\
\hline
\end{tabular}

+ denotes a positive response

+++ denotes a positive response to all three toluene enzyme-activity probes

*denotes the number of toluene probes where there was a positive response

LRGA: Lower Regional Gravel Aquifer

MRGA: Middle Regional Gravel Aquifer

URGA: Upper Regional Gravel Aquifer

sMMO: Soluble Methane Monooxygenase 


\section{Quantitative Toluene Enzyme-Activity Probe Results}

Toluene EAP data were quantified to determine where significant toluene activity was present (example micrograph in Figure 11). The quantitative toluene results are presented in Table 3. Highlighted values indicate moderate and high activity as described in the methods section. The refined binning criteria resulted in a good concordance between the qualitative and the quantitative results. Total microorganism counts (DAPI results, Table 3) showed that the Northwest Plume groundwater has total microbial population levels typical of groundwater systems with cell counts ranging from $10^{5}$ and $10^{6}$ cells per $\mathrm{mL}$ of sample.

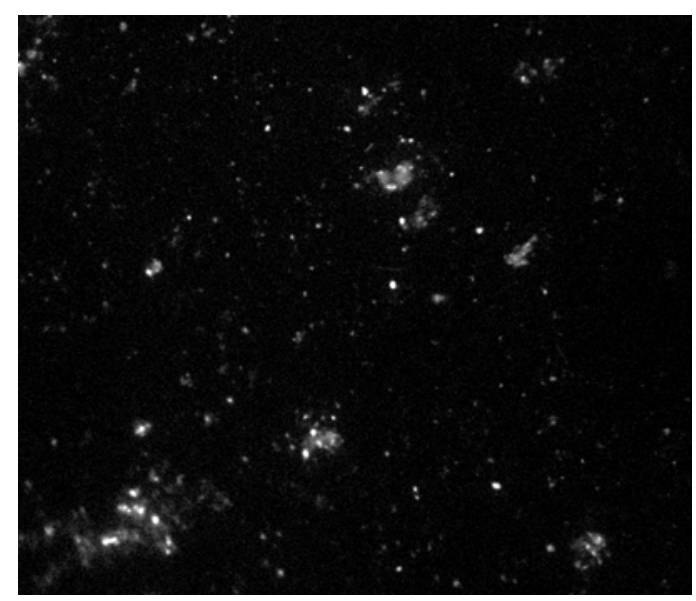

Figure 11. Micrograph of groundwater from MW66 exposed to phenylacetylene (PA).

Both of the control wells outside the plume (MW194 and MW197) showed high (significant) presence of toluene degraders and one of these wells showed sMMO activity. Among the 10 wells in the plume, $80 \%$ showed significant presence of toluene oxidizers, $50 \%$ showed sMMO activity, and $80 \%$ showed at least one type of oxidizing capability. Using the original DQO criteria (quantitative results above $1 \times 10^{3}$ cells $/ \mathrm{mL}$ ), 100\% of the control and plume wells showed at least one type of oxidizing activity. Notably, the activity appears to vary vertically within the RGA. The expression and activity are lower in the middle portion of the aquifer (MRGA) for both methane and aromatic (toluene) oxidation. Both the URGA and LRGA showed diverse and robust oxidation potential. Spatially, the presence and activity of methane and aromatic oxidizers was measured throughout the plume. The location of wells with positive enzymeactivity response is shown in relation to TCE footprint for the Northwest Plume at the PGDP (Figure 12). Wells with positive EAP response to the sMMO probe are denoted with an "M" and wells with significant positive response to the toluene EAPs are denoted with a " $T$ ". 
Table 3. Enzyme Activity Probe assay results for groundwater from monitoring wells at the Northwest Plume at PGDP.

\begin{tabular}{|c|c|c|c|c|c|c|c|c|}
\hline \multirow{3}{*}{$\begin{array}{c}\text { Monitoring } \\
\text { Well }\end{array}$} & \multirow{3}{*}{$\begin{array}{c}\text { Aquifer } \\
\text { Designation }\end{array}$} & \multirow{3}{*}{$\begin{array}{c}\text { Screened Interval } \\
\text { Depth } \\
\text { (ft bgs) }\end{array}$} & \multicolumn{2}{|c|}{ Qualitative data (6/4/7) } & \multirow{2}{*}{\multicolumn{3}{|c|}{$\begin{array}{c}\text { Toluene probes } \\
\text { Quantitative data } \\
\text { ( fluorescent cells } / \mathrm{mL} \text { ) }\end{array}$}} & \multirow{3}{*}{$\begin{array}{c}\text { Total -DAPI } \\
\text { cells } / \mathrm{mL}\end{array}$} \\
\hline & & & \multirow{2}{*}{$\begin{array}{l}\text { sMMO probe } \\
\text { Coumarin }\end{array}$} & \multirow{2}{*}{$\begin{array}{l}\text { Toluene } \\
\text { probes }\end{array}$} & & & & \\
\hline & & & & & 3HPA & PA & Cinnamonitrile & \\
\hline MW168 & \multirow{5}{*}{ URGA } & $63-68$ & - & - & nd & $2.41 \times 10^{3}$ & nd & $1.90 \times 10^{5}$ \\
\hline MW66 & & $55-60$ & + & +++ & $1.43 \times 10^{4}$ & $2.10 \times 10^{4}$ & $9.14 \times 10^{3}$ & $3.67 \times 10^{5}$ \\
\hline MW194 & & $47-52$ & + & +++ & $3.13 \times 10^{3}$ & $9.52 \times 10^{3}$ & $1.20 \times 10^{4}$ & $1.76 \times 10^{5}$ \\
\hline MW197 & & $58-63$ & - & + & $1.73 \times 10^{4}$ & $6.28 \times 10^{4}$ & $2.23 \times 10^{3}$ & $1.59 \times 10^{5}$ \\
\hline $\begin{array}{l}\text { MW197 } \\
\text { (resample) }\end{array}$ & & & na & na & $5.03 \times 10^{3}$ & $1.20 \times 10^{4}$ & $2.04 \times 10^{3}$ & $7.05 \times 10^{5}$ \\
\hline MW185 & \multirow{4}{*}{ MRGA } & $68-73$ & - & ++ & $1.79 \times 10^{4}$ & $1.37 \times 10^{4}$ & $1.95 \times 10^{3}$ & $9.75 \times 10^{5}$ \\
\hline MW242 & & $65-75$ & - & - & $3.57 \times 10^{3}$ & $1.24 \times 10^{3}$ & $8.85 \times 10^{3}$ & $7.76 \times 10^{5}$ \\
\hline MW243 & & $65-75$ & - & - & $3.29 \times 10^{3}$ & $4.61 \times 10^{3}$ & $1.32 \times 10^{3}$ & $4.27 \times 10^{5}$ \\
\hline MW381 & & $66-76$ & - & ++ & $6.14 \times 10^{4}$ & $3.52 \times 10^{4}$ & $5.51 \times 10^{3}$ & $9.66 \times 10^{5}$ \\
\hline MW262 & \multirow{5}{*}{ LRGA } & $90-95$ & + & +++ & $1.35 \times 10^{4}$ & $1.36 \times 10^{4}$ & $2.79 \times 10^{4}$ & $3.52 \times 10^{5}$ \\
\hline $\begin{array}{c}\text { MW } 262 \\
\text { (resample) }\end{array}$ & & & na & na & $1.05 \times 10^{4}$ & $1.22 \times 10^{4}$ & $5.71 \times 10^{3}$ & $2.84 \times 10^{5}$ \\
\hline MW340 & & $85.5-95.3$ & + & + & $3.63 \times 10^{2}$ & $9.57 \times 10^{3}$ & nd & $7.25 \times 10^{5}$ \\
\hline MW236 & & $69.5-79.5$ & + & +++ & $3.24 \times 10^{4}$ & $5.26 \times 10^{4}$ & $9.28 \times 10^{3}$ & $8.84 \times 10^{5}$ \\
\hline MW125 & & $78-88$ & + & ++ & $1.39 \times 10^{4}$ & $6.37 \times 10^{4}$ & $2.03 \times 10^{4}$ & $7.99 \times 10^{5}$ \\
\hline \multicolumn{9}{|c|}{ URGA: Upper Regional Gravel Aquifer } \\
\hline \multicolumn{6}{|c|}{ MRGA: Middle Regional Gravel Aquifer } & \multicolumn{3}{|c|}{$\mathrm{ft}$ bgs- feet below ground surface } \\
\hline \multicolumn{6}{|c|}{ LRGA: Lower Regional Gravel Aquifer } & \multicolumn{3}{|c|}{$\mu \mathrm{g} / \mathrm{L}$ - micrograms per liter } \\
\hline \multicolumn{6}{|c|}{ 3HPA: 3-hydroxy-phenylacetylene $\quad-->$ probe for toluene oxidase and related activity } & \multicolumn{3}{|c|}{$\mathrm{pCi} / \mathrm{L}$ - picocuries per liter } \\
\hline \multicolumn{6}{|c|}{ PA: Phenylacetylene --> probe for toluene oxidase and related activity } & \multicolumn{3}{|c|}{ cells $/ \mathrm{mL}$ - per milliliter } \\
\hline \multicolumn{9}{|c|}{ cinnamonitrile: probe for tolulene dioxygenase and related activity } \\
\hline \multicolumn{9}{|c|}{$\begin{array}{l}\text { DAPI: 4',6-Diamidino-2-Phenylindole (double stranded DNA staining) } \\
\text { Highlight denotes that the toluene probe response was considered moderate (fluorescent activity }>3 \times 10^{3} \text { cells/mL and }<8 \times 10^{3} \text { cells/mL) - see text for explanation }\end{array}$} \\
\hline \multicolumn{9}{|c|}{ Highlight denotes that the toluene probe response was considered moderate (fluorescent activity $>3 \times 10^{3}$ cells $/ \mathrm{mL}$ and $<8 \times 10^{3}$ cells $/ \mathrm{mL}$ ) - see text for explanation } \\
\hline
\end{tabular}




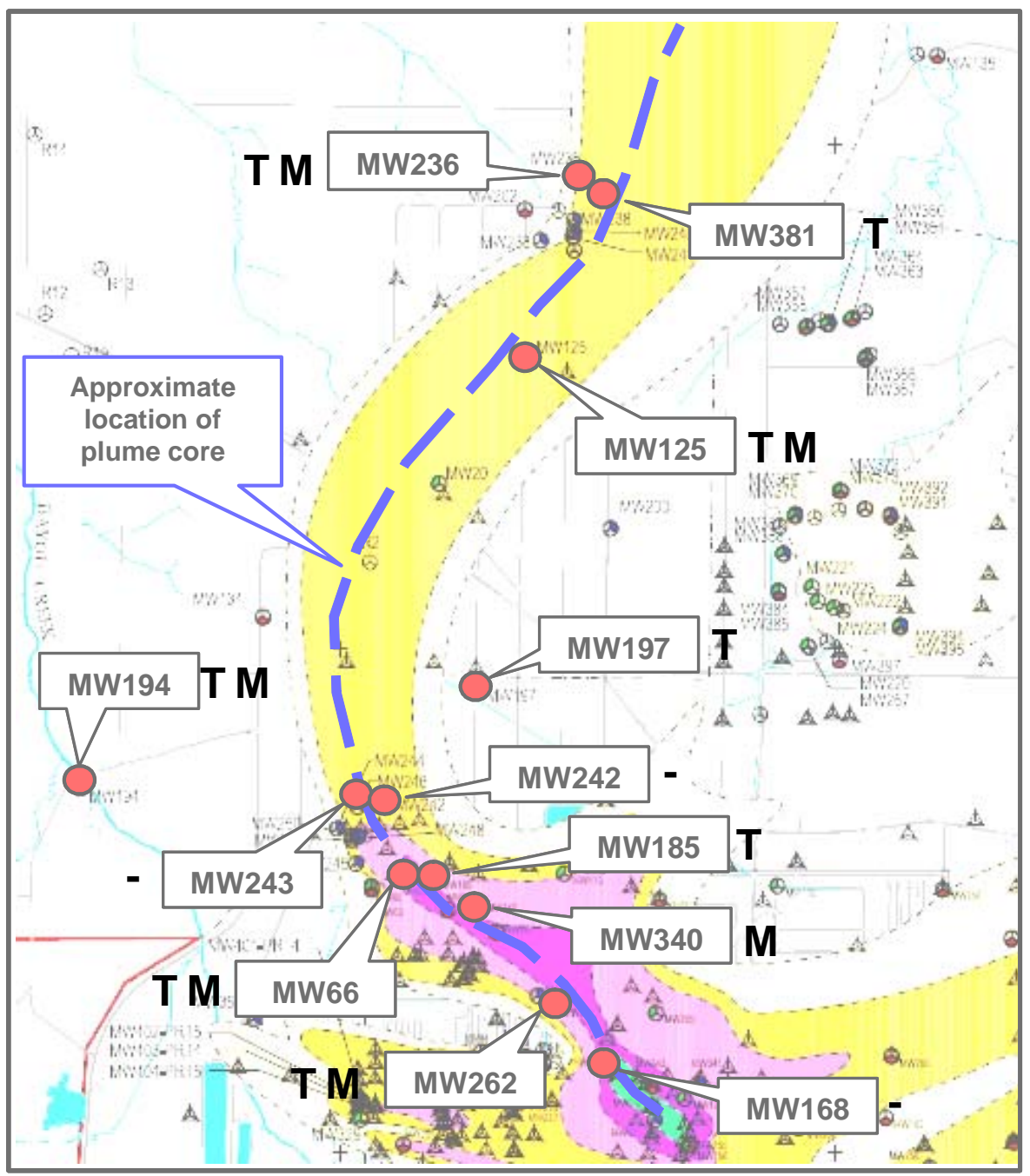

Figure 12: Map displaying wells where either sMMO enzyme-activity probe, denoted with an "M", and/or one or more toluene enzyme-activity probes, denoted with a "T", are significant. 


\section{DNA Control Study Results}

A DNA control study was performed to determine if key genes of interest were present in the microbial community isolated from groundwater collected from the PGDP monitoring wells. Although the DNA control study data do not provide information about enzyme activity at the site, the data do provide information about the potential for degradative activity at the site. DNA control study data are shown in Table 4 . A positive result $(+)$ indicates the gene of interest was amplified from the groundwater sample and a negative (-) indicates that amplification was not successful.

Positive response with the primers (Table 4) provides significant evidence that the oxygenase genes of interest, sMMO and toluene monooxygenases, are present in groundwater from each particular monitoring well. This DNA data provides (1) evidence of the potential for activity in any groundwater sample and (2) support for the enzyme activity assessment. Although amplification identifies which monitoring wells demonstrate a positive response to the genes of interest, it does not necessarily identify expression of the pathway and a positive response to the EAP.

The sMMO results (Table 3) were compared to the sMMO DNA control study (Table 4) to determine the degree of concordance between the EAP and the associated DNA targeted genes. Several wells showed a positive response to the genes of interest but did not display a positive response to the EAP. MW168, MW242, and MW243 were positive for the target genes, but EAP response was not displayed. This indicates that enzyme activity was not observed even though the genes necessary to produce the enzyme were present in the microbial population.

For aromatic oxidation, two of the EAP compounds, PA (phenylacetylene) and 3HPA (3hydroxyphenylacetylene), do not strictly correlate with a single enzymatic pathway. Each of the EAP probes reliably works with a preferred pathway but may also function with other pathways. For example, the 2 and 3 monooxygenase are both targeted with 3HPA; therefore, the two pathways can not be distinguished using EAP alone. However since the two PCR primer sets, RMO and PHE discriminate between the 2- and 3-monooxygenase pathways, some assessment of which pathway predominates is possible when the EAP data and PCR data are combined in a complementary fashion (see Table 5). Since the PGDP wells showed a general positive response with PA and HPA probes, the only way to determine the significance of the 2- versus the 3mooxygenase is to examine the PCR results. MW168, MW185, MW242, MW243, and MW340 all had a negative PCR response with the RMO primer sets but a positive with the PHE, suggesting that in these groundwater samples, 2-monooxygenase is a contributing pathway to cometabolic attenuation of TCE. Basic science efforts are underway to improve the understanding of the various potential combined response profiles for the EAPs and the PCR primers.

The only aromatic oxidation probe response that can be directly compared with the DNA results is cinnamontrile, which preferentially targets the dioxygenase (TOD) gene. MW 197, MW185, MW243 and MW340 assayed positive for the gene sequence for TOD when amplified using DNA primers. However, these wells showed low activity with the EAP cinnamonitrile. Wells 242, 381 and 236 assayed positive for the gene sequence for TOD and showed moderate activity with the EAP cinnamonitrile. This indicates that significant (high) enzyme activity was not 
observed in the EAP results for these seven wells even though the genes necessary to produce the enzyme were present in the microbial population.

Table 4. Results of DNA control studies. A positive mark indicates the gene of interest was amplified from the groundwater sample.

\begin{tabular}{cccccc}
$\begin{array}{c}\text { Monitoring } \\
\text { Well }\end{array}$ & $\begin{array}{c}\text { Aquifer } \\
\text { Designation }\end{array}$ & sMMO & RMO & PHE & TOD \\
\hline MW168 & & + & - & + & - \\
MW66 & URGA & + & + & + & + \\
MW194 & & + & + & + & + \\
MW197 & & - & + & + & + \\
\hline MW185 & & - & - & + & + \\
MW242 & MRGA & + & - & + & + \\
MW243 & & + & - & + & + \\
MW381 & & - & + & + & + \\
MW262 & & + & + & + & + \\
MW340 & LRGA & + & - & + & + \\
MW236 & & + & + & + & + \\
MW125 & & + & + & + &
\end{tabular}

URGA: Upper Regional Gravel Aquifer MRGA: Middle Regional Gravel Aquifer LRGA: Lower Regional Gravel Aquifer sMMO: Soluble Methane Monooxygenase

RMO: Ringhydroxylation Toluene Monooxygenase

PHE: Phenol Monooxygenase

TOD: Toluene/xylene Monooxygenase

Table 5. Relationships between EAPs, PCR, and toluene (aromatic) enzymatic pathways

\begin{tabular}{|l|l|l|}
\hline \multicolumn{1}{|c|}{ Pathway } & \multicolumn{1}{|c|}{ EAP response } & \multicolumn{1}{c|}{ PCR } \\
\hline $\begin{array}{l}\text { side-chain } \\
\text { monooxygenase }\end{array}$ & 3EB & TOL \\
\hline 2-monooxygenase & $\begin{array}{l}\text { 3HPA } \\
\text { maybe PA }\end{array}$ & PHE \\
\hline 3-monooxygenase & $\begin{array}{l}\text { 3HPA } \\
\text { maybe PA }\end{array}$ & RMO, PHE \\
\hline 4-monooxygenase & $\begin{array}{l}\text { NO PROBE } \\
\text { RMO, PHE }\end{array}$ & TOD \\
\hline 2,3-dioxygenase & $\begin{array}{l}\text { trans-cinnamonitrile } \\
\text { maybe 3HPA }\end{array}$ & \\
\hline
\end{tabular}




\section{$\underline{\text { Supplementary T-RFLP Study Results }}$}

The full report for the TRFLP study is provided in Appendix B. The following criteria were set forth prior to the analysis of groundwater from the Northwest Plume for TRFLP community profiling to assess whether the samples were providing representative formation water:

1. Community profiles will differ based on TCE concentrations,

2. Community profiles will differ based on geochemical or biogeochemical parameters,

3. Community profiles of the wells that were cleaned in the same time frame should look more similar to one another than those that were cleaned more recently or never,

4. If a biofilm is present, all of the profiles should have similarities that "outweigh" the differences.

In general, the diversity profiles/fingerprints of each monitoring well evaluated were greater than expected. Each well produced a distinct profile, detailing the micro-niches and diversity of genetic and physiological activities of microbial populations in situ. Based on this overall diversity and the distinct differences of each of the fingerprints generated, is it clear that:

0 There is no dominance of any one organism or even group of organisms in the groundwater plume based on DNA amplification.

o Dominant organisms from any given monitoring well are different than those from other monitoring wells, even when the wells exhibit similar geochemical or contaminant concentrations.

o The groundwater evaluated using EAPs does not appear biased by biofouling in the well casings.

o The groundwater sampled appears to represent distinct micro-communities present within the Northwest Plume, as would be expected if the plume, rather than the well casings and associated biofilms, were being sampled and analyzed.

These data provide scientifically and statistically defensible results that the groundwater sampled and analyzed for enzyme activity primarily represents sampling of the groundwater plume (i.e. formation water), rather than sampling the micro-communities present in specific and/or individual well casings, or biofilms present therein.

\section{Geochemical Results}

A summary of key geochemical results is presented in Table 6. A complete dataset is provided in Appendix A. The groundwater geochemistry varied spatially within the Northwest Plume. Nonetheless, all of the wells had conditions generally conducive to aerobic cometabolism (e.g., $\mathrm{pH}$, oxygen, redox potential, etc.). The overall geochemistry within the plume was similar to that of the two control wells in these key parameters, with the main difference being the presence of elevated TCE and ${ }^{99} \mathrm{Tc}$ in the plume. Organic carbon was generally low $(<1 \mathrm{mg} / \mathrm{L})$ in all wells indicating an oligotrophic condition in which the microbial ecology would be dominated by organisms that can survive under low nutrient conditions. Data are tabulated for both the primary sampling (May 2007) and the follow-up sampling (December 2007). The geochemical data for the two sampling events are similar indicating that the plume geochemistry is relatively stable over intermediate timeframes (e.g., months). 
Table 6. Summary of key geochemical characteristics in the PGDP Northwest Plume - Samples were collected from 12 wells to support a study of attenuation mechanisms for TCE

Data from Primary Sampling: May 2007

\begin{tabular}{|c|c|c|c|c|c|c|c|c|c|c|c|c|c|c|c|c|}
\hline \multirow{2}{*}{$\begin{array}{l}\text { Monitoring } \\
\text { Well }\end{array}$} & \multirow{2}{*}{$\begin{array}{c}\text { Aquifer } \\
\text { Designation }\end{array}$} & \multirow{2}{*}{$\begin{array}{l}\text { Screened } \\
\text { Interval } \\
\text { Depth (ft) }\end{array}$} & \multirow{2}{*}{$\begin{array}{c}\text { TCE } \\
(\mu \mathrm{g} / \mathrm{L})\end{array}$} & \multirow{2}{*}{$\begin{array}{c}\text { DCE } \\
(\mu \mathrm{g} / \mathrm{L})\end{array}$} & \multicolumn{2}{|c|}{$\begin{array}{c}\text { technetium } \\
(\mathrm{pCi} / \mathrm{L})\end{array}$} & \multirow{2}{*}{$\begin{array}{c}\text { dissolved } \\
\text { oxygen } \\
\text { (mg/L) }\end{array}$} & \multirow{2}{*}{$\begin{array}{c}\mathrm{pH} \\
\text { (std units) }\end{array}$} & \multirow{2}{*}{\begin{tabular}{|c|} 
oxidation - \\
reduction \\
potential \\
$(\mathrm{mV})$
\end{tabular}} & \multirow{2}{*}{$\begin{array}{c}\text { specific } \\
\text { conductivity } \\
\text { (umhos/cm) }\end{array}$} & \multirow{2}{*}{$\begin{array}{c}\text { chloride } \\
\text { (mg/L) }\end{array}$} & \multirow{2}{*}{$\begin{array}{l}\text { nitrate } \\
(\mathrm{mg} / \mathrm{L})\end{array}$} & \multirow{2}{*}{$\begin{array}{l}\text { sulfate } \\
\text { (mg/L) }\end{array}$} & \multirow{2}{*}{$\begin{array}{l}\text { Iron (II) } \\
\text { (mg/L) }\end{array}$} & \multirow{2}{*}{$\begin{array}{c}\text { total } \\
\text { organic } \\
\text { carbon } \\
(\mathrm{mg} / \mathrm{L})\end{array}$} & \multirow{2}{*}{$\begin{array}{l}\text { alkalinity } \\
(\mathrm{mg} / \mathrm{L} \text { as } \\
\mathrm{CaCO}_{3} \text { ) }\end{array}$} \\
\hline & & & & & result & error & & & & & & & & & & \\
\hline $\begin{array}{c}\text { MW168 } \\
\text { MW66 } \\
\text { MW194 } \\
\text { MW197 } \\
\end{array}$ & URGA & $\begin{array}{l}63-68 \\
55-60 \\
47-52 \\
58-63 \\
\end{array}$ & $\begin{array}{c}110 \\
700 \\
1 \\
3.9 \\
\end{array}$ & $\begin{array}{l}<100 \\
<5 \\
<5 \\
<5 \\
\end{array}$ & $\begin{array}{l}-- \\
-- \\
-- \\
-- \\
\end{array}$ & $\begin{array}{l}-- \\
-- \\
-- \\
-- \\
\end{array}$ & $\begin{array}{l}2.5 \\
5.8 \\
5.4 \\
0.6 \\
\end{array}$ & $\begin{array}{l}5.76 \\
6.01 \\
5.98 \\
6.01 \\
\end{array}$ & $\begin{array}{c}428 \\
304 \\
367 \\
-7 \\
\end{array}$ & $\begin{array}{l}533 \\
213 \\
249 \\
440 \\
\end{array}$ & $\begin{array}{l}92 \\
13 \\
27 \\
65 \\
\end{array}$ & $\begin{array}{c}17 \\
5.8 \\
7.0 \\
<4.4 \\
\end{array}$ & $\begin{array}{l}11 \\
11 \\
6.5 \\
16 \\
\end{array}$ & $\begin{array}{c}0.035 \\
<0.02 \\
<0.02 \\
23.9 \\
\end{array}$ & $\begin{array}{l}<1 \\
<1 \\
<1 \\
2.3 \\
\end{array}$ & $\begin{array}{l}77 \\
72 \\
72 \\
78 \\
\end{array}$ \\
\hline $\begin{array}{l}\text { MW185 } \\
\text { MW242 } \\
\text { MW243 } \\
\text { MW381 }\end{array}$ & MRGA & $\begin{array}{l}68-73 \\
65-75 \\
65-75 \\
66-76\end{array}$ & $\begin{array}{c}3300 \\
110 \\
100 \\
50\end{array}$ & $\begin{array}{l}140 \\
<5 \\
<5 \\
<5\end{array}$ & $\begin{array}{l}- \\
-- \\
-- \\
--\end{array}$ & $\begin{array}{l}- \\
-- \\
-- \\
--\end{array}$ & $\begin{array}{l}2.0 \\
1.5 \\
5.9 \\
3.2 \\
\end{array}$ & $\begin{array}{l}6.08 \\
5.62 \\
6.22 \\
6.18 \\
\end{array}$ & $\begin{array}{l}527 \\
166 \\
252 \\
286 \\
\end{array}$ & $\begin{array}{l}437 \\
358 \\
459 \\
372 \\
\end{array}$ & $\begin{array}{l}57 \\
63 \\
12 \\
41\end{array}$ & $\begin{array}{c}7.5 \\
<4.4 \\
<4.4 \\
6.7\end{array}$ & $\begin{array}{l}12 \\
12 \\
67 \\
24 \\
\end{array}$ & $\begin{array}{c}<0.02 \\
8.13 \\
0.046 \\
<0.02\end{array}$ & $\begin{array}{l}<1 \\
<1 \\
<1 \\
<1\end{array}$ & $\begin{array}{c}109 \\
55 \\
113 \\
98\end{array}$ \\
\hline $\begin{array}{l}\text { MW262 } \\
\text { MW340 } \\
\text { MW236 } \\
\text { MW125 }\end{array}$ & LRGA & $\begin{array}{c}90-95 \\
85.5-95.3 \\
69.5-79.5 \\
78-88\end{array}$ & $\begin{array}{c}950 \\
6500 \\
21 \\
700 \\
\end{array}$ & $\begin{array}{l}<50 \\
<250 \\
<5 \\
<25\end{array}$ & $\begin{array}{l}-- \\
-- \\
-- \\
--\end{array}$ & $\begin{array}{l}-- \\
-- \\
-- \\
--\end{array}$ & $\begin{array}{l}0.6 \\
3.5 \\
3.4 \\
2.8 \\
\end{array}$ & $\begin{array}{l}5.89 \\
5.94 \\
6.19 \\
6.05 \\
\end{array}$ & $\begin{array}{l}339 \\
367 \\
332 \\
303 \\
\end{array}$ & $\begin{array}{l}679 \\
460 \\
321 \\
302 \\
\end{array}$ & $\begin{array}{c}110 \\
61 \\
31 \\
33 \\
\end{array}$ & $\begin{array}{l}5.6 \\
7.2 \\
7.3 \\
5.8 \\
\end{array}$ & $\begin{array}{l}39 \\
28 \\
21 \\
19 \\
\end{array}$ & $\begin{array}{l}<0.02 \\
<0.02 \\
<0.02 \\
<0.02\end{array}$ & $\begin{array}{l}<1 \\
<1 \\
<1 \\
<1\end{array}$ & $\begin{array}{c}105 \\
109 \\
90 \\
91\end{array}$ \\
\hline
\end{tabular}

Data from Follow-up Sampling: December 2007

\begin{tabular}{|c|c|c|c|c|c|c|c|c|c|c|}
\hline \multirow{2}{*}{$\begin{array}{l}\text { Monitoring } \\
\text { Well }\end{array}$} & \multirow{2}{*}{$\begin{array}{c}\text { Aquifer } \\
\text { Designation }\end{array}$} & \multirow{2}{*}{$\begin{array}{l}\text { Screened } \\
\text { Interval } \\
\text { Depth (ft) }\end{array}$} & \multirow{2}{*}{$\begin{array}{c}\text { TCE } \\
(\mu \mathrm{g} / \mathrm{L})\end{array}$} & \multirow{2}{*}{$\begin{array}{c}\text { DCE } \\
(\mu \mathrm{g} / \mathrm{L})\end{array}$} & \multicolumn{2}{|c|}{$\begin{array}{l}\text { technetium } \\
\text { (pCi / L) }\end{array}$} & \multirow{2}{*}{$\begin{array}{c}\text { dissolved } \\
\text { oxygen }\end{array}$} & \multirow{2}{*}{$\begin{array}{c}\mathrm{pH} \\
\text { (std units) }\end{array}$} & \multirow{2}{*}{$\begin{array}{c}\text { oxidation - } \\
\text { reduction } \\
\text { potential } \\
\text { (mV) }\end{array}$} & \multirow{2}{*}{$\begin{array}{c}\text { specific } \\
\text { conductivity } \\
\text { (umhos/cm) }\end{array}$} \\
\hline & & & & & result & error & & & & \\
\hline MW168 & \multirow{4}{*}{ URGA } & $63-68$ & 110 & $<1.2$ & 2400 & 45 & 3.1 & 5.87 & 233 & 492 \\
\hline MW66 & & $55-60$ & 930 & $<5$ & 530 & 24 & 5.7 & 6.01 & 285 & 190 \\
\hline MW194 & & $47-52$ & 1 & $<1$ & ND & -- & 3.6 & 6.20 & 114 & 251 \\
\hline MW197 & & $58-63$ & 3.5 & $<1$ & ND & -- & 0.7 & 6.13 & 2 & 424 \\
\hline MW185 & \multirow{4}{*}{ MRGA } & $68-73$ & 3600 & 76 & 696 & 26 & 1.7 & 6.10 & 269 & 382 \\
\hline MW242 & & $65-75$ & 150 & 4.4 & 110 & 15 & 0.8 & 6.09 & 63 & 395 \\
\hline MW243 & & $65-75$ & 590 & $<5$ & 306 & 19 & 3.8 & 5.96 & 150 & 378 \\
\hline MW381 & & $66-76$ & 47 & $<1$ & 21.5 & 12.5 & 6.1 & 6.65 & 261 & 502 \\
\hline MW262 & \multirow{4}{*}{ LRGA } & $90-95$ & 1400 & 11 & 519 & 23 & 0.8 & 5.97 & 218 & 601 \\
\hline MW340 & & $85.5-95.3$ & 9700 & $<80$ & 647 & 26 & 3.2 & 6.04 & 254 & 453 \\
\hline MW236 & & $69.5-79.5$ & 72 & $<1$ & 29.1 & 12.7 & 6.1 & 6.65 & 261 & 502 \\
\hline MW125 & & $78-88$ & 620 & $<5$ & 220 & 18 & 2.9 & 6.11 & 400 & 310 \\
\hline
\end{tabular}

Notes:

measured or not available

"

Total and dissoved copper were nondetect $(<0.025 \mathrm{mg} / \mathrm{L})$ in all wells

All data from both sample events are presented in appendices. 


\section{Compound Specific Isotope Analysis}

Table 7 presents a high level summary of the CSIA results. These data will be presented and interpreted in more detail in a stand alone document that reflects the interpretation of the principal investigators. Qualitatively, there appear to be some changes in the carbon isotope ratios in the TCE as the plume moves from the source toward the distal region of the plume. The complete data set (including detailed assessment of the replicates and statistics) are being evaluated vis-à-vis the decision estimation rules, and will be incorporated into the determination of the Project Team.

Table 7. Summary of CSIA results.

\begin{tabular}{|c|c|}
\hline Sample ID & TCE d13C (permil) \\
\hline PGDP NW plume wells along flow path & \multicolumn{2}{|c|}{ near source } \\
\hline MW-168 & -24.8 \\
MW-262 & -25.8 \\
MW-340 & -25.9 \\
MW-185 & -25.9 \\
MW-242 & -24.6 \\
MW-243 & -25.3 \\
MW-125 & -25.6 \\
MW-381 & -25.4 \\
MW-236 & -25.3 \\
\hline MW-66 & -25.3 \\
\hline PGDP well near downgradient source \\
\hline PGDP control wells outside plume \\
\hline MW-194 & na \\
MW-197 & -23.1 \\
\hline
\end{tabular}




\section{Discussion and Key Findings}

The EAP data suggest that aerobic cometabolic activity is occurring in groundwater from monitoring wells at the Northwest Plume at PGDP and is contributing to the attenuation of TCE. The positive EAP responses in the control wells from outside the plume suggest that there is widespread potential for the aerobic degradation of TCE. The geochemistry throughout the Northwest Plume is spatially variable; however, all of the wells exhibit geochemical conditions consistent with that required for aerobic cometabolism. There are no clear geochemical factors strongly correlated with either high enzyme activity or with low enzyme activity. EAP conclusions are presented as follows:

Overall Conclusions for all wells --

- sMMO activity was detected in 6 out of the 12 monitoring wells sampled. Significant aromatic oxidation enzyme activity was measured in 10 out of the 12 wells sampled, and moderate aromatic oxidation enzyme activity was measured in 1 additional well.

- $\quad$ sMMO activity was not detected at MW168, MW197, MW185, MW242, MW243 or MW381. However, the DNA control study demonstrated the presence of the gene sequences needed to produce sMMO in MW168, MW242 and MW243. Therefore, these three locations have the potential for sMMO-related degradative microbial activity, but it was not expressed sufficiently to generate a positive EAP assay response.

- Toluene dioxygenase (TOD) activity, as detected by the cinnamonitrile enzyme probe, was low in MW168, MW197, MW185, MW243 and MW340. TOD activity was moderate in MW381. However, all monitoring locations except MW168 demonstrated a positive response to the TOD primers during the DNA control study. Therefore, the data indicate a widespread genetic potential for TOD-related degradative microbial activity, but this potential was not expressed sufficiently to generate significant EAP assay responses in approximately $50 \%$ of the wells tested.

- Toluene monooxygenase (TMO) activity, as detected by the PA and 3HPA enzyme probes, was moderate (MW242 and MW243) or significant in all tested wells.

Conclusions for the three RGA zones --

- For the sMMO probe:

o Activity was detected in two of the four URGA wells, MW66 and MW194.

o Activity was not detected in any of MRGA wells.

o Activity was detected in all of the LRGA wells: MW262, MW340, MW236, and MW125.

- $\quad$ For the aromatic toluene probes:

o Significant activity was detected in three of the four URGA wells: MW66, MW194, and MW197. 
o Significant activity was detected in three of the four MRGA wells (MW185, MW242, and MW381) and moderate activity was detected in the remaining well, MW243.

o Significant activity was detected all four LRGA wells: MW262, MW236, MW340, and MW125.

The goals of this aerobic cometabolism assessment were developed by the Project Team, and are presented in detail in the document TCE Fate \& Transport Project, Evaluation of Aerobic Degradation, Enzyme Activity Probe Sampling Scoping Document (KRCEE, 2007). Based on the results of this assessment, the following decision/estimation conclusions can be stated to address the five key questions from the TCE Fate and Transport Team:

o Decision / Estimation Statement \#1. Bacteria capable of aerobically biodegrading TCE are present in the Northwest Plume at PGDP.

o Decisions / Estimation Statement \#2. Decision/estimation conclusions for \#2 (related to CSIA) will be developed in a companion report based on evaluation of compound specific isotope results and statistical interpretations.

o Decision / Estimation Statement \#3. The number and distribution of bacteria appear sufficient to contribute to the biodegradation of TCE in RGA groundwater. The organic carbon in this oligotrophic, "nutrient limited" system is low. The microbial community appears to be stable and sustainable; that is, the control and plume well data are similar.

o Decision / Estimation Statement \#4. Based on the information collected during this phase of the work, a follow-on kinetic rate study is recommended to develop a site-specific degradation rate constant. The Project Team recommends determining degradation rates for two wells*: MW125, and either MW236 or MW381.

o Decision / Estimation Statement \#5. The previously-estimated degradation rates for PGDP, based on comparison of plume-scale TCE transport to a conservative tracer $\left({ }^{99} \mathrm{Tc}\right)$, are consistent with the published literature for aerobic cometabolism in large aerobic plumes, with a half-life in the range of 9 to 25 years. Additional kinetic data for multiple sites across the United States are being developed through research funded by DOE and DoD. These data will be published and used for reference to support the final estimated rates for PGDP.

* Well MW125 is a promising candidate for the kinetic study phase of the work based on its: a) location (in the mid-plume area where attenuation processes are particularly important), b) representative EAP responses, c) representative geochemistry, and d) representative easily measured TCE concentrations. Wells MW236 and MW381 are aerobic and are "in-line" with MW 125. Including one of these distal wells will help bound the attenuation rates in the plume. As with other aspects of the PGDP studies, the kinetic study will require effort to assure the logistics are in place to handle samples containing technetium co-contamination.

Well TCE (DEC-07) Number of probes positive Notes MW125 $\quad 700 \quad 3$

MW236 $\quad 21$

MW $381 \quad 50$

3 downgradient of MW125, along plume center 2 downgradient of MW125, along plume center 


\section{References}

Baldwin, B. R., C. H. Nakatsu, and L. Nies. 2003. Detection and Enumeration of Aromatic Oxygenase Genes by Multiplex and Real-Time PCR. Appl. Environ. Microbiol. 69:33503358.

BJC 2004. Paducah Site Environmental Monitoring Plan, BJC/PAD-285/R3, Bechtel Jacobs Company LLC, Paducah, KY.

Clingenpeel, S. R., W. K. Keener, C. R. Keller, K. De Jesus, M. H. Howard, and M. E. Watwood. 2005. Activity-dependent fluorescent labeling of bacterial cells expressing the TOL pathway. J. Microb. Meth. 60:41-46.

Clausen, J.L., N.C. Sturchio, L.J. Heraty, L. Huang, T. Abrajano. 1997. Evaluation of Natural Attenuation Processes for Trichloroethylene and Technetium-99 in the Northeast and Northwest Plumes at the Paducah Gaseous Diffusion Plant, Paducah, Kentucky. Lockheed Martin Energy Systems. Paducah, KY. KY/EM-113.

DOE, 1995. In Situ Bioremediation Using Horizontal Wells: Innovative Technology Summary Report. U. S. Department of Energy Office of Environmental Management, Washington DC, April, 1995, 14 pp.

EPA. 1998. Technical Protocol for Evaluating Natural Attenuation of Chlorinated Solvents in Ground Water. U.S. Environmental Protection Agency. EPA/600/R-98/128. Washington, DC.

Fries, M. R., G. D. Hopkins, P. L. McCarty, L. J. Forney and J. M. Tiedje, 1997. Microbial succession during a field evaluation of phenol and toluene as the primary substrates for trichloroethene cometabolism. Applied and Environmental Microbiology, vol 63, No. 4, pp 1515-1522.

Grindstaff, M., 1998. Bioremediation of Chlorinated Solvent Groundwater. U. S. Environmental Protection Agency, Technology Innovation Office, National Network of Environmental Management Studies Fellowship Report. Available at: http://www.epa.gov/tio/download/remed/meganfin.pdf (site visited 13 Feb 2008).

Jacobs Engineering. 1997. Groundwater Restoration Potential and Natural Attenuation at the Paducah Gaseous Diffusion Plant, Paducah, Kentucky. Internal letter report to DOE, September 15, 1997.

Kauffman, M. E., W. K. Keener, M. E. Watwood, and R. M. Lehman. 2003. Use of 3hydroxyphenylacetylene for activity-dependent, fluorescent labeling of bacteria that degrade toluene via 3-methylcatechol. J. Microb. Meth. 55:801-805.

Keener, W. K., M. E. Watwood, and W. A. Apel. 1998. Activity-dependent fluorescent labeling of bacteria that degrade toluene 2,3-dioxygenase. Appl. Microbiol. Biotechnol. 49:455-462. 
Keener, W. K., M. E. Watwood, K. D. Schaller, M. R. Walton, J. K. Partin, W. A. Smith, and S. R. Clingenpeel. 2001. Use of selective inhibitors and chromogenic substrates to differentiate bacteria based on toluene oxygenase activity. J. Microb. Meth. 46:171-185.

Lee, M.H., S.C. Clingenpeel, O.P. Leiser, and M.E. Watwood, 2005. Molecular and Physiological Characterization of Aerobic TCE Degradation Potential. Eighth International In Situ and On-Site Bioremediation Symposium. Battelle Press, Columbus, $\mathrm{OH}$.

Lee, M.H., S.C. Clingenpeel, O.P. Leiser, R.A. Wymore, K.S.Sorenson, Jr., and M.E. Watwood, 2008. Activity-Dependent Labeling of Oxygenase Enzymes in a TrichloroetheneContaminated Groundwater Site. Environmental Pollution. 153:238-246.

Lee, M. H., 2007. Application of Enzyme Activity Probes to Characterize Aerobic Microorganisms in Groundwater at PGDP, INL, \& elsewhere. Kentucky Research Consortium for Energy and the Environment 2007 Scientific and Technical Symposium, University of Kentucky, October 30-31 2007.

Lu, X., J. T. Wilson, D. H. Kampbell, 2006. Relationship between Dehalococcoides DNA in ground water and rates of reductive dechlorination at field scale. Water Research, Vol. 40, pp $3131-3140$

McCarty, P. L., M. N. Goltz, G. D. Hopkins, M. E. Dolan, J. P. Allen, B. T., Kawakami and T. J. Carrothers, 1998. Full-Scale Evaluation of In Situ Cometabolic Degradation of Trichloroethylene in Groundwater through Toluene Injection, Environmental Science and Technology, vol 32, No. 1, pp 88-100.

Miller, A. R., W. K. Keener, M. E. Watwood, and F. F. Roberto. 2002. A rapid fluorescencebased assay for detecting soluble methane monooxygenase. Appl. Microbiol. Biotech. 58:183-188.

PRS, 2007. Tricholorethene and Technetium-99 Contamination in the Regional Gravel Aquifer for the Calendar Year 2005, Paducah Gaseous Diffusion Plant, Paducah, Kentucky, PRS/Project/0019.

Wymore, R.A., M.H. Lee, A.R. Miller, F.S. Colwell, M.E. Watwood, and K.S. Sorenson, Jr. (2007). Field Evidence for Intrinsic Aerobic Chlorinated Ethene Cometabolism by Methanotrophs Expressing sMMO. Bioremediation Journal. 11(3):125-139. 


\section{Appendix A}

\section{Raw Geochemistry Data}




\section{Primary Samples (May 2007)}




\begin{tabular}{|c|c|c|c|c|c|c|c|c|c|}
\hline Method & AnaType & Chemical Name & Station & Results & Units & $\begin{array}{c}\text { Result } \\
\text { Qualifier }\end{array}$ & Date Collected & $\begin{array}{c}\text { Date } \\
\text { Analyzed }\end{array}$ & $\begin{array}{l}\text { Detection } \\
\text { Limit }\end{array}$ \\
\hline SW846-9056 & ANION & Chloride & MW125 & 33 & $\mathrm{mg} / \mathrm{L}$ & & $5 / 21 / 2007$ & $5 / 22 / 2007$ & \\
\hline SW846-9056 & ANION & Chloride & MW168 & 92 & $\mathrm{mg} / \mathrm{L}$ & & $5 / 16 / 2007$ & $5 / 17 / 2007$ & 20 \\
\hline SW846-9056 & ANION & Chloride & MW185 & 57 & $\mathrm{mg} / \mathrm{L}$ & & $5 / 23 / 2007$ & $5 / 24 / 2007$ & 10 \\
\hline SW846-9056 & ANION & Chloride & MW194 & 27 & $\mathrm{mg} / \mathrm{L}$ & & $5 / 17 / 2007$ & $5 / 21 / 2007$ & 2 \\
\hline SW846-9056 & ANION & Chloride & MW197 & 65 & $\mathrm{mg} / \mathrm{L}$ & & $5 / 21 / 2007$ & $5 / 22 / 2007$ & 5 \\
\hline SW846-9056 & ANION & Chloride & MW236 & 31 & $\mathrm{mg} / \mathrm{L}$ & & $5 / 22 / 2007$ & $5 / 23 / 2007$ & 2 \\
\hline SW846-9056 & ANION & Chloride & MW236 & 31 & $\mathrm{mg} / \mathrm{L}$ & & $5 / 22 / 2007$ & $5 / 23 / 2007$ & 2 \\
\hline SW846-9056 & ANION & Chloride & MW242 & 63 & $\mathrm{mg} / \mathrm{L}$ & & $5 / 17 / 2007$ & $5 / 18 / 2007$ & 10 \\
\hline SW846-9056 & ANION & Chloride & MW243 & 12 & $\mathrm{mg} / \mathrm{L}$ & & $5 / 15 / 2007$ & $5 / 16 / 2007$ & 2 \\
\hline SW846-9056 & ANION & Chloride & MW262 & 110 & $\mathrm{mg} / \mathrm{L}$ & & $5 / 16 / 2007$ & $5 / 17 / 2007$ & 20 \\
\hline SW846-9056 & ANION & Chloride & MW340 & 61 & $\mathrm{mg} / \mathrm{L}$ & & $5 / 23 / 2007$ & $5 / 24 / 2007$ & 10 \\
\hline SW846-9056 & ANION & Chloride & MW381 & 41 & $\mathrm{mg} / \mathrm{L}$ & & $5 / 22 / 2007$ & $5 / 23 / 2007$ & 2 \\
\hline SW846-9056 & ANION & Chloride & MW66 & 13 & $\mathrm{mg} / \mathrm{L}$ & & $5 / 15 / 2007$ & $5 / 16 / 2007$ & 2 \\
\hline SW846-9056 & ANION & Chloride & QC & 2 & $\mathrm{mg} / \mathrm{L}$ & $\mathrm{U}$ & $5 / 22 / 2007$ & $5 / 23 / 2007$ & 2 \\
\hline SW846-9056 & ANION & Chloride & $\mathrm{QC}$ & 2 & $\mathrm{mg} / \mathrm{L}$ & $\mathrm{U}$ & $5 / 22 / 2007$ & $5 / 23 / 2007$ & 2 \\
\hline SW846-9056 & ANION & Nitrate & MW125 & 5.8 & $\mathrm{mg} / \mathrm{L}$ & & $5 / 21 / 2007$ & $5 / 22 / 2007$ & 4.4 \\
\hline SW846-9056 & ANION & Nitrate & MW168 & 17 & $\mathrm{mg} / \mathrm{L}$ & & $5 / 16 / 2007$ & $5 / 17 / 2007$ & 4.4 \\
\hline SW846-9056 & ANION & Nitrate & MW185 & 7.5 & $\mathrm{mg} / \mathrm{L}$ & & $5 / 23 / 2007$ & $5 / 24 / 2007$ & 4.4 \\
\hline SW846-9056 & ANION & Nitrate & MW194 & 7 & $\mathrm{mg} / \mathrm{L}$ & & $5 / 17 / 2007$ & $5 / 21 / 2007$ & 4.4 \\
\hline SW846-9056 & ANION & Nitrate & MW197 & 4.4 & $\mathrm{mg} / \mathrm{L}$ & $U$ & $5 / 21 / 2007$ & $5 / 22 / 2007$ & 4.4 \\
\hline SW846-9056 & ANION & Nitrate & MW236 & 7.3 & $\mathrm{mg} / \mathrm{L}$ & & $5 / 22 / 2007$ & $5 / 23 / 2007$ & 4.4 \\
\hline SW846-9056 & ANION & Nitrate & MW236 & 7.3 & $\mathrm{mg} / \mathrm{L}$ & & $5 / 22 / 2007$ & $5 / 23 / 2007$ & 4.4 \\
\hline SW846-9056 & ANION & Nitrate & MW242 & 4.4 & $\mathrm{mg} / \mathrm{L}$ & $\mathrm{U}$ & $5 / 17 / 2007$ & $5 / 18 / 2007$ & 4.4 \\
\hline SW846-9056 & ANION & Nitrate & MW243 & 4.4 & $\mathrm{mg} / \mathrm{L}$ & $u$ & $5 / 15 / 2007$ & $5 / 16 / 2007$ & 4.4 \\
\hline SW846-9056 & ANION & Nitrate & MW262 & 5.6 & $\mathrm{mg} / \mathrm{L}$ & & $5 / 16 / 2007$ & $5 / 17 / 2007$ & 4.4 \\
\hline SW846-9056 & ANION & Nitrate & MW340 & 7.2 & $\mathrm{mg} / \mathrm{L}$ & & $5 / 23 / 2007$ & $5 / 24 / 2007$ & 4.4 \\
\hline SW846-9056 & ANION & Nitrate & MW381 & 6.7 & $\mathrm{mg} / \mathrm{L}$ & & $5 / 22 / 2007$ & $5 / 23 / 2007$ & 4.4 \\
\hline SW846-9056 & ANION & Nitrate & MW66 & 5.8 & $\mathrm{mg} / \mathrm{L}$ & & $5 / 15 / 2007$ & $5 / 16 / 2007$ & 4.4 \\
\hline SW846-9056 & ANION & Nitrate & QC & 4.4 & $\mathrm{mg} / \mathrm{L}$ & $u$ & $5 / 22 / 2007$ & $5 / 23 / 2007$ & 4.4 \\
\hline SW846-9056 & ANION & Nitrate & $\mathrm{QC}$ & 4.4 & $\mathrm{mg} / \mathrm{L}$ & $\mathrm{U}$ & $5 / 22 / 2007$ & $5 / 23 / 2007$ & 4.4 \\
\hline SW846-9056 & ANION & Orthophosphate & MW125 & 3.1 & $\mathrm{mg} / \mathrm{L}$ & $U$ & $5 / 21 / 2007$ & $5 / 22 / 2007$ & 3.1 \\
\hline SW846-9056 & ANION & Orthophosphate & MW168 & 3.1 & $\mathrm{mg} / \mathrm{L}$ & $\mathrm{BU}$ & $5 / 16 / 2007$ & $5 / 17 / 2007$ & 3.1 \\
\hline SW846-9056 & ANION & Orthophosphate & MW185 & 3.1 & $\mathrm{mg} / \mathrm{L}$ & $U$ & $5 / 23 / 2007$ & $5 / 24 / 2007$ & 3.1 \\
\hline SW846-9056 & ANION & Orthophosphate & MW194 & 3.1 & $\mathrm{mg} / \mathrm{L}$ & $u$ & $5 / 17 / 2007$ & $5 / 21 / 2007$ & 3.1 \\
\hline SW846-9056 & ANION & Orthophosphate & MW197 & 3.1 & $\mathrm{mg} / \mathrm{L}$ & $u$ & $5 / 21 / 2007$ & $5 / 22 / 2007$ & 3.1 \\
\hline SW846-9056 & ANION & Orthophosphate & MW236 & 3.1 & $\mathrm{mg} / \mathrm{L}$ & u & $5 / 22 / 2007$ & $5 / 23 / 2007$ & 3.1 \\
\hline SW846-9056 & ANION & Orthophosphate & MW236 & 3.1 & $\mathrm{mg} / \mathrm{L}$ & $\mathrm{U}$ & $5 / 22 / 2007$ & $5 / 23 / 2007$ & 3.1 \\
\hline SW846-9056 & ANION & Orthophosphate & MW242 & 3.1 & $\mathrm{mg} / \mathrm{L}$ & $\mathrm{U}$ & $5 / 17 / 2007$ & $5 / 18 / 2007$ & 3.1 \\
\hline SW846-9056 & ANION & Orthophosphate & MW243 & 16 & $\mathrm{mg} / \mathrm{L}$ & $B X$ & $5 / 15 / 2007$ & $5 / 16 / 2007$ & 3.1 \\
\hline SW846-9056 & ANION & Orthophosphate & MW262 & 3.1 & $\mathrm{mg} / \mathrm{L}$ & $\mathrm{BU}$ & $5 / 16 / 2007$ & $5 / 17 / 2007$ & 3.1 \\
\hline SW846-9056 & ANION & Orthophosphate & MW340 & 3.1 & $\mathrm{mg} / \mathrm{L}$ & $U$ & $5 / 23 / 2007$ & $5 / 24 / 2007$ & 3.1 \\
\hline SW846-9056 & ANION & Orthophosphate & MW381 & 3.1 & $\mathrm{mg} / \mathrm{L}$ & 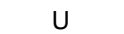 & $5 / 22 / 2007$ & $5 / 23 / 2007$ & 3.1 \\
\hline SW846-9056 & ANION & Orthophosphate & MW66 & 3.1 & $\mathrm{mg} / \mathrm{L}$ & BUX & $5 / 15 / 2007$ & $5 / 16 / 2007$ & 3.1 \\
\hline SW846-9056 & ANION & Orthophosphate & $\mathrm{QC}$ & 3.1 & $\mathrm{mg} / \mathrm{L}$ & U & $5 / 22 / 2007$ & $5 / 23 / 2007$ & 3.1 \\
\hline SW846-9056 & ANION & Orthophosphate & QC & 3.1 & $\mathrm{mg} / \mathrm{L}$ & $\mathrm{U}$ & $5 / 22 / 2007$ & $5 / 23 / 2007$ & 3.1 \\
\hline SW846-9056 & ANION & Sulfate & MW125 & 19 & $\mathrm{mg} / \mathrm{L}$ & & $5 / 21 / 2007$ & $5 / 22 / 2007$ & 2 \\
\hline SW846-9056 & ANION & Sulfate & MW168 & 11 & $\mathrm{mg} / \mathrm{L}$ & & $5 / 16 / 2007$ & $5 / 17 / 2007$ & 2 \\
\hline SW846-9056 & ANION & Sulfate & MW185 & 12 & $\mathrm{mg} / \mathrm{L}$ & & $5 / 23 / 2007$ & $5 / 24 / 2007$ & 2 \\
\hline SW846-9056 & ANION & Sulfate & MW194 & 6.5 & $\mathrm{mg} / \mathrm{L}$ & & $5 / 17 / 2007$ & $5 / 21 / 2007$ & 2 \\
\hline SW846-9056 & ANION & Sulfate & MW197 & 16 & $\mathrm{mg} / \mathrm{L}$ & & $5 / 21 / 2007$ & $5 / 22 / 2007$ & 2 \\
\hline SW846-9056 & ANION & Sulfate & MW236 & 21 & $\mathrm{mg} / \mathrm{L}$ & & $5 / 22 / 2007$ & $5 / 23 / 2007$ & 2 \\
\hline SW846-9056 & ANION & Sulfate & MW236 & 21 & $\mathrm{mg} / \mathrm{L}$ & & $5 / 22 / 2007$ & $5 / 23 / 2007$ & 2 \\
\hline SW846-9056 & ANION & Sulfate & MW242 & 12 & $\mathrm{mg} / \mathrm{L}$ & & $5 / 17 / 2007$ & $5 / 18 / 2007$ & 2 \\
\hline SW846-9056 & ANION & Sulfate & MW243 & 67 & $\mathrm{mg} / \mathrm{L}$ & & $5 / 15 / 2007$ & $5 / 16 / 2007$ & 5 \\
\hline SW846-9056 & ANION & Sulfate & MW262 & 39 & $\mathrm{mg} / \mathrm{L}$ & & $5 / 16 / 2007$ & $5 / 17 / 2007$ & 2 \\
\hline SW846-9056 & ANION & Sulfate & MW340 & 28 & $\mathrm{mg} / \mathrm{L}$ & & $5 / 23 / 2007$ & $5 / 24 / 2007$ & 2 \\
\hline SW846-9056 & ANION & Sulfate & MW381 & 24 & $\mathrm{mg} / \mathrm{L}$ & & $5 / 22 / 2007$ & $5 / 23 / 2007$ & 2 \\
\hline SW846-9056 & ANION & Sulfate & MW66 & 11 & $\mathrm{mg} / \mathrm{L}$ & & $5 / 15 / 2007$ & $5 / 16 / 2007$ & 2 \\
\hline SW846-9056 & ANION & Sulfate & QC & 2 & $\mathrm{mg} / \mathrm{L}$ & U & $5 / 22 / 2007$ & $5 / 23 / 2007$ & 2 \\
\hline SW846-9056 & ANION & Sulfate & $\mathrm{QC}$ & 2 & mg/L & $\mathrm{U}$ & $5 / 22 / 2007$ & $5 / 23 / 2007$ & 2 \\
\hline FS & FS & Conductivity & MW125 & 302 & umho/cm & & $5 / 21 / 2007$ & & \\
\hline FS & FS & Conductivity & MW168 & 533 & umho/cm & & $5 / 16 / 2007$ & & \\
\hline FS & FS & Conductivity & MW185 & 437 & umho/cm & & $5 / 23 / 2007$ & & \\
\hline FS & FS & Conductivity & MW194 & 249 & umho/cm & & $5 / 17 / 2007$ & & \\
\hline FS & FS & Conductivity & MW197 & 440 & umho/cm & & $5 / 21 / 2007$ & & \\
\hline FS & $\mathrm{FS}$ & Conductivity & MW236 & 321 & umho/cm & & $5 / 22 / 2007$ & & \\
\hline FS & FS & Conductivity & MW236 & 321 & umho/cm & & $5 / 22 / 2007$ & & \\
\hline FS & $\mathrm{FS}$ & Conductivity & MW242 & 358 & umho/cm & & $5 / 17 / 2007$ & & \\
\hline FS & FS & Conductivity & MW243 & 439 & umho/cm & & $5 / 15 / 2007$ & & \\
\hline
\end{tabular}




\begin{tabular}{|c|c|c|c|c|c|c|c|c|c|}
\hline Method & AnaType & Chemical Name & Station & Results & Units & $\begin{array}{c}\text { Result } \\
\text { Qualifier }\end{array}$ & Date Collected & $\begin{array}{c}\text { Date } \\
\text { Analyzed }\end{array}$ & $\begin{array}{l}\text { Detection } \\
\text { Limit }\end{array}$ \\
\hline FS & FS & Conductivity & MW262 & 679 & umho/cm & & $5 / 16 / 2007$ & & \\
\hline FS & FS & Conductivity & MW340 & 460 & umho/cm & & $5 / 23 / 2007$ & & \\
\hline FS & FS & Conductivity & MW381 & 372 & umho/cm & & $5 / 22 / 2007$ & & \\
\hline FS & FS & Conductivity & MW66 & 213 & umho/cm & & $5 / 15 / 2007$ & & \\
\hline FS & FS & Dissolved Oxygen & MW125 & 2.77 & $\mathrm{mg} / \mathrm{L}$ & & $5 / 21 / 2007$ & & \\
\hline FS & FS & Dissolved Oxygen & MW168 & 2.46 & $\mathrm{mg} / \mathrm{L}$ & & $5 / 16 / 2007$ & & \\
\hline FS & FS & Dissolved Oxygen & MW185 & 1.96 & $\mathrm{mg} / \mathrm{L}$ & & $5 / 23 / 2007$ & & \\
\hline FS & FS & Dissolved Oxygen & MW194 & 5.43 & $\mathrm{mg} / \mathrm{L}$ & & $5 / 17 / 2007$ & & \\
\hline FS & FS & Dissolved Oxygen & MW197 & 0.62 & $\mathrm{mg} / \mathrm{L}$ & & $5 / 21 / 2007$ & & \\
\hline FS & FS & Dissolved Oxygen & MW236 & 3.36 & $\mathrm{mg} / \mathrm{L}$ & & $5 / 22 / 2007$ & & \\
\hline FS & FS & Dissolved Oxygen & MW236 & 3.36 & $\mathrm{mg} / \mathrm{L}$ & & $5 / 22 / 2007$ & & \\
\hline FS & FS & Dissolved Oxygen & MW242 & 1.5 & $\mathrm{mg} / \mathrm{L}$ & & $5 / 17 / 2007$ & & \\
\hline FS & FS & Dissolved Oxygen & MW243 & 5.94 & $\mathrm{mg} / \mathrm{L}$ & & $5 / 15 / 2007$ & & \\
\hline FS & FS & Dissolved Oxygen & MW262 & 0.6 & $\mathrm{mg} / \mathrm{L}$ & & $5 / 16 / 2007$ & & \\
\hline FS & FS & Dissolved Oxygen & MW340 & 3.51 & $\mathrm{mg} / \mathrm{L}$ & & $5 / 23 / 2007$ & & \\
\hline FS & FS & Dissolved Oxygen & MW381 & 3.23 & $\mathrm{mg} / \mathrm{L}$ & & $5 / 22 / 2007$ & & \\
\hline FS & FS & Dissolved Oxygen & MW66 & 5.78 & $\mathrm{mg} / \mathrm{L}$ & & $5 / 15 / 2007$ & & \\
\hline FS & FS & $\mathrm{pH}$ & MW125 & 6.05 & Std Unit & & $5 / 21 / 2007$ & & \\
\hline FS & FS & $\mathrm{pH}$ & MW168 & 5.76 & Std Unit & & $5 / 16 / 2007$ & & \\
\hline FS & FS & $\mathrm{pH}$ & MW185 & 6.08 & Std Unit & & $5 / 23 / 2007$ & & \\
\hline FS & FS & $\mathrm{pH}$ & MW194 & 5.98 & Std Unit & & $5 / 17 / 2007$ & & \\
\hline FS & FS & $\mathrm{pH}$ & MW197 & 6.01 & Std Unit & & $5 / 21 / 2007$ & & \\
\hline FS & FS & $\mathrm{pH}$ & MW236 & 6.19 & Std Unit & & $5 / 22 / 2007$ & & \\
\hline FS & FS & $\mathrm{pH}$ & MW236 & 6.19 & Std Unit & & $5 / 22 / 2007$ & & \\
\hline FS & FS & $\mathrm{pH}$ & MW242 & 5.62 & Std Unit & & $5 / 17 / 2007$ & & \\
\hline FS & FS & $\mathrm{pH}$ & MW243 & 6.22 & Std Unit & & $5 / 15 / 2007$ & & \\
\hline FS & FS & $\mathrm{pH}$ & MW262 & 5.89 & Std Unit & & $5 / 16 / 2007$ & & \\
\hline FS & FS & $\mathrm{pH}$ & MW340 & 5.94 & Std Unit & & $5 / 23 / 2007$ & & \\
\hline FS & FS & $\mathrm{pH}$ & MW381 & 6.18 & Std Unit & & $5 / 22 / 2007$ & & \\
\hline FS & FS & $\mathrm{pH}$ & MW66 & 6.01 & Std Unit & & $5 / 15 / 2007$ & & \\
\hline FS & FS & Redox & MW125 & 303 & $\mathrm{mV}$ & & $5 / 21 / 2007$ & & \\
\hline FS & FS & Redox & MW168 & 428 & $\mathrm{mV}$ & & $5 / 16 / 2007$ & & \\
\hline FS & FS & Redox & MW185 & 527 & $\mathrm{mV}$ & & $5 / 23 / 2007$ & & \\
\hline FS & FS & Redox & MW194 & 367 & $\mathrm{mV}$ & & $5 / 17 / 2007$ & & \\
\hline FS & FS & Redox & MW197 & -7 & $\mathrm{mV}$ & & $5 / 21 / 2007$ & & \\
\hline FS & FS & Redox & MW236 & 332 & $\mathrm{mV}$ & & $5 / 22 / 2007$ & & \\
\hline FS & FS & Redox & MW236 & 332 & $\mathrm{mV}$ & & $5 / 22 / 2007$ & & \\
\hline FS & FS & Redox & MW242 & 166 & $\mathrm{mV}$ & & $5 / 17 / 2007$ & & \\
\hline FS & FS & Redox & MW243 & 252 & $\mathrm{mV}$ & & $5 / 15 / 2007$ & & \\
\hline FS & FS & Redox & MW262 & 339 & $\mathrm{mV}$ & & $5 / 16 / 2007$ & & \\
\hline FS & FS & Redox & MW340 & 367 & $\mathrm{mV}$ & & $5 / 23 / 2007$ & & \\
\hline FS & FS & Redox & MW381 & 286 & $\mathrm{mV}$ & & $5 / 22 / 2007$ & & \\
\hline FS & FS & Redox & MW66 & 304 & $\mathrm{mV}$ & & $5 / 15 / 2007$ & & \\
\hline FS & FS & Temperature & MW125 & 64.1 & $\operatorname{deg} F$ & & $5 / 21 / 2007$ & & \\
\hline FS & FS & Temperature & MW168 & 65.1 & $\operatorname{deg} F$ & & $5 / 16 / 2007$ & & \\
\hline FS & FS & Temperature & MW185 & 70.3 & $\operatorname{deg} F$ & & $5 / 23 / 2007$ & & \\
\hline FS & FS & Temperature & MW194 & 61.5 & $\operatorname{deg} F$ & & $5 / 17 / 2007$ & & \\
\hline FS & $\mathrm{FS}$ & Temperature & MW197 & 61.2 & $\operatorname{deg} F$ & & $5 / 21 / 2007$ & & \\
\hline FS & FS & Temperature & MW236 & 62.4 & $\operatorname{deg} F$ & & $5 / 22 / 2007$ & & \\
\hline FS & FS & Temperature & MW236 & 62.4 & $\operatorname{deg} F$ & & $5 / 22 / 2007$ & & \\
\hline FS & FS & Temperature & MW242 & 59.7 & $\operatorname{deg} F$ & & $5 / 17 / 2007$ & & \\
\hline FS & FS & Temperature & MW243 & 61.7 & $\operatorname{deg} F$ & & $5 / 15 / 2007$ & & \\
\hline FS & FS & Temperature & MW262 & 64.6 & $\operatorname{deg} F$ & & $5 / 16 / 2007$ & & \\
\hline FS & FS & Temperature & MW340 & 74.1 & $\operatorname{deg} F$ & & $5 / 23 / 2007$ & & \\
\hline FS & FS & Temperature & MW381 & 61 & $\operatorname{deg} F$ & & $5 / 22 / 2007$ & & \\
\hline FS & $\mathrm{FS}$ & Temperature & MW66 & 65.9 & $\operatorname{deg} F$ & & $5 / 15 / 2007$ & & \\
\hline SW846-6010B & METAL & Calcium & MW125 & 21.8 & $\mathrm{mg} / \mathrm{L}$ & & $5 / 21 / 2007$ & $6 / 8 / 2007$ & 1 \\
\hline SW846-6010B & METAL & Calcium & MW168 & 33.6 & $\mathrm{mg} / \mathrm{L}$ & & $5 / 16 / 2007$ & $6 / 8 / 2007$ & 1 \\
\hline SW846-6010B & METAL & Calcium & MW185 & 39 & $\mathrm{mg} / \mathrm{L}$ & & $5 / 23 / 2007$ & $6 / 8 / 2007$ & 1 \\
\hline SW846-6010B & METAL & Calcium & MW194 & 16 & $\mathrm{mg} / \mathrm{L}$ & & $5 / 17 / 2007$ & $6 / 8 / 2007$ & 1 \\
\hline SW846-6010B & METAL & Calcium & MW197 & 24.6 & $\mathrm{mg} / \mathrm{L}$ & & $5 / 21 / 2007$ & $6 / 8 / 2007$ & 1 \\
\hline SW846-6010B & METAL & Calcium & MW236 & 23.2 & $\mathrm{mg} / \mathrm{L}$ & & $5 / 22 / 2007$ & $6 / 8 / 2007$ & 1 \\
\hline SW846-6010B & METAL & Calcium & MW236 & 23.2 & $\mathrm{mg} / \mathrm{L}$ & & $5 / 22 / 2007$ & $6 / 8 / 2007$ & 1 \\
\hline SW846-6010B & METAL & Calcium & MW242 & 23.9 & $\mathrm{mg} / \mathrm{L}$ & & $5 / 17 / 2007$ & $6 / 8 / 2007$ & 1 \\
\hline SW846-6010B & METAL & Calcium & MW243 & 18.2 & $\mathrm{mg} / \mathrm{L}$ & & $5 / 15 / 2007$ & $6 / 8 / 2007$ & 1 \\
\hline SW846-6010B & METAL & Calcium & MW262 & 50.6 & $\mathrm{mg} / \mathrm{L}$ & & $5 / 16 / 2007$ & $6 / 8 / 2007$ & 1 \\
\hline SW846-6010B & METAL & Calcium & MW340 & 31.2 & $\mathrm{mg} / \mathrm{L}$ & & $5 / 23 / 2007$ & $6 / 8 / 2007$ & 1 \\
\hline SW846-6010B & METAL & Calcium & MW381 & 27.2 & $\mathrm{mg} / \mathrm{L}$ & & $5 / 22 / 2007$ & $6 / 8 / 2007$ & 1 \\
\hline SW846-6010B & METAL & Calcium & MW66 & 18.8 & $\mathrm{mg} / \mathrm{L}$ & & $5 / 15 / 2007$ & $6 / 8 / 2007$ & 1 \\
\hline
\end{tabular}




\begin{tabular}{|c|c|c|c|c|c|c|c|c|c|}
\hline Method & AnaType & Chemical Name & Station & Results & Units & $\begin{array}{c}\text { Result } \\
\text { Qualifier }\end{array}$ & Date Collected & $\begin{array}{c}\text { Date } \\
\text { Analyzed }\end{array}$ & $\begin{array}{l}\text { Detection } \\
\text { Limit }\end{array}$ \\
\hline SW846-6010B & METAL & Calcium & $\mathrm{QC}$ & 1 & $\mathrm{mg} / \mathrm{L}$ & U & $5 / 22 / 2007$ & $6 / 8 / 2007$ & 1 \\
\hline SW846-6010B & METAL & Calcium & QC & 1 & $\mathrm{mg} / \mathrm{L}$ & $U$ & $5 / 22 / 2007$ & $6 / 8 / 2007$ & 1 \\
\hline SW846-6010B & METAL & Copper & MW125 & 0.025 & $\mathrm{mg} / \mathrm{L}$ & $\mathrm{BU}$ & $5 / 21 / 2007$ & $6 / 8 / 2007$ & 0.025 \\
\hline SW846-6010B & METAL & Copper & MW168 & 0.025 & $\mathrm{mg} / \mathrm{L}$ & $\mathrm{BU}$ & $5 / 16 / 2007$ & $6 / 8 / 2007$ & 0.025 \\
\hline SW846-6010B & METAL & Copper & MW185 & 0.025 & $\mathrm{mg} / \mathrm{L}$ & $\mathrm{BU}$ & $5 / 23 / 2007$ & $6 / 8 / 2007$ & 0.025 \\
\hline SW846-6010B & METAL & Copper & MW194 & 0.025 & $\mathrm{mg} / \mathrm{L}$ & $\mathrm{BU}$ & $5 / 17 / 2007$ & $6 / 8 / 2007$ & 0.025 \\
\hline SW846-6010B & METAL & Copper & MW197 & 0.025 & $\mathrm{mg} / \mathrm{L}$ & $\mathrm{BU}$ & $5 / 21 / 2007$ & $6 / 8 / 2007$ & 0.025 \\
\hline SW846-6010B & METAL & Copper & MW236 & 0.025 & $\mathrm{mg} / \mathrm{L}$ & $\mathrm{BU}$ & $5 / 22 / 2007$ & $6 / 8 / 2007$ & 0.025 \\
\hline SW846-6010B & METAL & Copper & MW242 & 0.025 & $\mathrm{mg} / \mathrm{L}$ & $\mathrm{BU}$ & $5 / 17 / 2007$ & $6 / 8 / 2007$ & 0.025 \\
\hline SW846-6010B & METAL & Copper & MW243 & 0.025 & $\mathrm{mg} / \mathrm{L}$ & $\mathrm{BU}$ & $5 / 15 / 2007$ & $6 / 8 / 2007$ & 0.025 \\
\hline SW846-6010B & METAL & Copper & MW262 & 0.025 & $\mathrm{mg} / \mathrm{L}$ & $\mathrm{BU}$ & $5 / 16 / 2007$ & $6 / 8 / 2007$ & 0.025 \\
\hline SW846-6010B & METAL & Copper & MW340 & 0.025 & $\mathrm{mg} / \mathrm{L}$ & $\mathrm{BU}$ & $5 / 23 / 2007$ & $6 / 8 / 2007$ & 0.025 \\
\hline SW846-6010B & METAL & Copper & MW381 & 0.025 & $\mathrm{mg} / \mathrm{L}$ & $\mathrm{BU}$ & $5 / 22 / 2007$ & $6 / 8 / 2007$ & 0.025 \\
\hline SW846-6010B & METAL & Copper & MW66 & 0.025 & $\mathrm{mg} / \mathrm{L}$ & $\mathrm{BU}$ & $5 / 15 / 2007$ & $6 / 8 / 2007$ & 0.025 \\
\hline SW846-6010B & METAL & Copper & QC & 0.025 & $\mathrm{mg} / \mathrm{L}$ & $\mathrm{BU}$ & $5 / 22 / 2007$ & $6 / 8 / 2007$ & 0.025 \\
\hline SM-3500-Fe D & METAL & Iron $(2+)$ & MW125 & 0.02 & $\mathrm{mg} / \mathrm{L}$ & $U$ & $5 / 21 / 2007$ & $5 / 22 / 2007$ & 0.02 \\
\hline SM-3500-Fe D & METAL & Iron (2+) & MW168 & 0.02 & $\mathrm{mg} / \mathrm{L}$ & $U$ & $5 / 16 / 2007$ & $5 / 17 / 2007$ & 0.02 \\
\hline SM-3500-Fe D & METAL & Iron $(2+)$ & MW185 & 0.02 & $\mathrm{mg} / \mathrm{L}$ & $U$ & $5 / 23 / 2007$ & $5 / 24 / 2007$ & 0.02 \\
\hline SM-3500-Fe D & METAL & Iron $(2+)$ & MW194 & 0.02 & $\mathrm{mg} / \mathrm{L}$ & $\mathrm{U}$ & $5 / 17 / 2007$ & $5 / 18 / 2007$ & 0.02 \\
\hline SM-3500-Fe D & METAL & Iron (2+) & MW197 & 23.9 & $\mathrm{mg} / \mathrm{L}$ & & $5 / 21 / 2007$ & $5 / 22 / 2007$ & 0.02 \\
\hline SM-3500-Fe D & METAL & Iron $(2+)$ & MW236 & 0.02 & $\mathrm{mg} / \mathrm{L}$ & $U$ & $5 / 22 / 2007$ & $5 / 23 / 2007$ & 0.02 \\
\hline SM-3500-Fe D & METAL & Iron (2+) & MW236 & 0.02 & $\mathrm{mg} / \mathrm{L}$ & $U$ & $5 / 22 / 2007$ & $5 / 23 / 2007$ & 0.02 \\
\hline SM-3500-Fe D & METAL & Iron (2+) & MW242 & 8.13 & $\mathrm{mg} / \mathrm{L}$ & & $5 / 17 / 2007$ & $5 / 18 / 2007$ & 0.02 \\
\hline SM-3500-Fe D & METAL & Iron (2+) & MW243 & 0.0462 & $\mathrm{mg} / \mathrm{L}$ & & $5 / 15 / 2007$ & $5 / 16 / 2007$ & 0.02 \\
\hline SM-3500-Fe D & METAL & Iron $(2+)$ & MW262 & 0.02 & $\mathrm{mg} / \mathrm{L}$ & $U$ & $5 / 16 / 2007$ & $5 / 17 / 2007$ & 0.02 \\
\hline SM-3500-Fe D & METAL & Iron $(2+)$ & MW340 & 0.02 & $\mathrm{mg} / \mathrm{L}$ & $\mathrm{U}$ & $5 / 23 / 2007$ & $5 / 24 / 2007$ & 0.02 \\
\hline SM-3500-Fe D & METAL & Iron $(2+)$ & MW381 & 0.02 & $\mathrm{mg} / \mathrm{L}$ & $U$ & $5 / 22 / 2007$ & $5 / 23 / 2007$ & 0.02 \\
\hline SM-3500-Fe D & METAL & Iron $(2+)$ & MW66 & 0.0353 & $\mathrm{mg} / \mathrm{L}$ & & $5 / 15 / 2007$ & $5 / 16 / 2007$ & 0.02 \\
\hline SM-3500-Fe D & METAL & Iron $(2+)$ & QC & 0.02 & $\mathrm{mg} / \mathrm{L}$ & $U$ & $5 / 22 / 2007$ & $5 / 23 / 2007$ & 0.02 \\
\hline SM-3500-Fe D & METAL & Iron (2+) & QC & 0.02 & $\mathrm{mg} / \mathrm{L}$ & $U$ & $5 / 22 / 2007$ & $5 / 23 / 2007$ & 0.02 \\
\hline SW846-6010B & METAL & Magnesium & MW125 & 8.44 & $\mathrm{mg} / \mathrm{L}$ & & $5 / 21 / 2007$ & $6 / 8 / 2007$ & 0.025 \\
\hline SW846-6010B & METAL & Magnesium & MW194 & 6.84 & $\mathrm{mg} / \mathrm{L}$ & & $5 / 17 / 2007$ & $6 / 8 / 2007$ & 0.025 \\
\hline SW846-6010B & METAL & Magnesium & MW197 & 11.2 & $\mathrm{mg} / \mathrm{L}$ & & $5 / 21 / 2007$ & $6 / 8 / 2007$ & 0.025 \\
\hline SW846-6010B & METAL & Magnesium & MW236 & 9.14 & $\mathrm{mg} / \mathrm{L}$ & & $5 / 22 / 2007$ & $6 / 8 / 2007$ & 0.025 \\
\hline SW846-6010B & METAL & Magnesium & MW236 & 9.16 & $\mathrm{mg} / \mathrm{L}$ & & $5 / 22 / 2007$ & $6 / 8 / 2007$ & 0.025 \\
\hline SW846-6010B & METAL & Magnesium & MW242 & 10.6 & $\mathrm{mg} / \mathrm{L}$ & & $5 / 17 / 2007$ & $6 / 8 / 2007$ & 0.025 \\
\hline SW846-6010B & METAL & Magnesium & MW243 & 7.38 & $\mathrm{mg} / \mathrm{L}$ & & $5 / 15 / 2007$ & $6 / 8 / 2007$ & 0.025 \\
\hline SW846-6010B & METAL & Magnesium & MW262 & 19.8 & $\mathrm{mg} / \mathrm{L}$ & & $5 / 16 / 2007$ & $6 / 8 / 2007$ & 0.025 \\
\hline SW846-6010B & METAL & Magnesium & MW340 & 12.4 & $\mathrm{mg} / \mathrm{L}$ & & $5 / 23 / 2007$ & $6 / 8 / 2007$ & 0.025 \\
\hline SW846-6010B & METAL & Magnesium & MW381 & 10.7 & $\mathrm{mg} / \mathrm{L}$ & & $5 / 22 / 2007$ & $6 / 8 / 2007$ & 0.025 \\
\hline SW846-6010B & METAL & Magnesium & MW66 & 6.21 & $\mathrm{mg} / \mathrm{L}$ & & $5 / 15 / 2007$ & $6 / 8 / 2007$ & 0.025 \\
\hline SW846-6010B & METAL & Magnesium & QC & 0.025 & $\mathrm{mg} / \mathrm{L}$ & $U$ & $5 / 22 / 2007$ & $6 / 8 / 2007$ & 0.025 \\
\hline SW846-6010B & METAL & Magnesium & QC & 0.025 & $\mathrm{mg} / \mathrm{L}$ & $U$ & $5 / 22 / 2007$ & $6 / 8 / 2007$ & 0.025 \\
\hline SW846-6010B & METAL & Potassium & MW125 & 2 & $\mathrm{mg} / \mathrm{L}$ & $U$ & $5 / 21 / 2007$ & $6 / 8 / 2007$ & 2 \\
\hline SW846-6010B & METAL & Potassium & MW168 & 2 & $\mathrm{mg} / \mathrm{L}$ & $U$ & $5 / 16 / 2007$ & $6 / 8 / 2007$ & 2 \\
\hline SW846-6010B & METAL & Potassium & MW185 & 2 & $\mathrm{mg} / \mathrm{L}$ & $U$ & $5 / 23 / 2007$ & $6 / 8 / 2007$ & 2 \\
\hline SW846-6010B & METAL & Potassium & MW194 & 2 & $\mathrm{mg} / \mathrm{L}$ & $U$ & $5 / 17 / 2007$ & $6 / 8 / 2007$ & 2 \\
\hline SW846-6010B & METAL & Potassium & MW197 & 2 & $\mathrm{mg} / \mathrm{L}$ & $U$ & $5 / 21 / 2007$ & $6 / 8 / 2007$ & 2 \\
\hline SW846-6010B & METAL & Potassium & MW236 & 2 & $\mathrm{mg} / \mathrm{L}$ & $U$ & $5 / 22 / 2007$ & $6 / 8 / 2007$ & 2 \\
\hline SW846-6010B & METAL & Potassium & MW236 & 2 & $\mathrm{mg} / \mathrm{L}$ & $U$ & $5 / 22 / 2007$ & $6 / 8 / 2007$ & 2 \\
\hline SW846-6010B & METAL & Potassium & MW242 & 2 & $\mathrm{mg} / \mathrm{L}$ & $U$ & $5 / 17 / 2007$ & $6 / 8 / 2007$ & 2 \\
\hline SW846-6010B & METAL & Potassium & MW243 & 2 & $\mathrm{mg} / \mathrm{L}$ & $U$ & $5 / 15 / 2007$ & $6 / 8 / 2007$ & 2 \\
\hline SW846-6010B & METAL & Potassium & MW262 & 2.3 & $\mathrm{mg} / \mathrm{L}$ & & $5 / 16 / 2007$ & $6 / 8 / 2007$ & 2 \\
\hline SW846-6010B & METAL & Potassium & MW340 & 2 & $\mathrm{mg} / \mathrm{L}$ & $U$ & $5 / 23 / 2007$ & $6 / 8 / 2007$ & 2 \\
\hline SW846-6010B & METAL & Potassium & MW381 & 2 & $\mathrm{mg} / \mathrm{L}$ & $U$ & $5 / 22 / 2007$ & $6 / 8 / 2007$ & 2 \\
\hline SW846-6010B & METAL & Potassium & MW66 & 2 & $\mathrm{mg} / \mathrm{L}$ & $\mathrm{U}$ & $5 / 15 / 2007$ & $6 / 8 / 2007$ & 2 \\
\hline SW846-6010B & METAL & Potassium & $\mathrm{QC}$ & 2 & $\mathrm{mg} / \mathrm{L}$ & $U$ & $5 / 22 / 2007$ & $6 / 8 / 2007$ & 2 \\
\hline SW846-6010B & METAL & Potassium & QC & 2 & $\mathrm{mg} / \mathrm{L}$ & $U$ & $5 / 22 / 2007$ & $6 / 8 / 2007$ & 2 \\
\hline SW846-6010B & METAL & Sodium & MW125 & 31.9 & $\mathrm{mg} / \mathrm{L}$ & & $5 / 21 / 2007$ & $6 / 8 / 2007$ & 2 \\
\hline SW846-6010B & METAL & Sodium & MW168 & 46.2 & $\mathrm{mg} / \mathrm{L}$ & & $5 / 16 / 2007$ & $6 / 8 / 2007$ & 2 \\
\hline SW846-6010B & METAL & Sodium & MW185 & 31.2 & $\mathrm{mg} / \mathrm{L}$ & & $5 / 23 / 2007$ & $6 / 8 / 2007$ & 2 \\
\hline SW846-6010B & METAL & Sodium & MW194 & 27.8 & $\mathrm{mg} / \mathrm{L}$ & & $5 / 17 / 2007$ & $6 / 8 / 2007$ & 2 \\
\hline SW846-6010B & METAL & Sodium & MW197 & 25.8 & $\mathrm{mg} / \mathrm{L}$ & & $5 / 21 / 2007$ & $6 / 8 / 2007$ & 2 \\
\hline SW846-6010B & METAL & Sodium & MW236 & 30.4 & $\mathrm{mg} / \mathrm{L}$ & & $5 / 22 / 2007$ & $6 / 8 / 2007$ & 2 \\
\hline
\end{tabular}




\begin{tabular}{|c|c|c|c|c|c|c|c|c|c|}
\hline Method & AnaType & Chemical Name & Station & Results & Units & $\begin{array}{c}\text { Result } \\
\text { Qualifier }\end{array}$ & Date Collected & $\begin{array}{c}\text { Date } \\
\text { Analyzed }\end{array}$ & $\begin{array}{l}\text { Detection } \\
\text { Limit }\end{array}$ \\
\hline SW846-6010B & METAL & Sodium & MW242 & 25.7 & $\mathrm{mg} / \mathrm{L}$ & & $5 / 17 / 2007$ & $6 / 8 / 2007$ & 2 \\
\hline SW846-6010B & METAL & Sodium & MW243 & 63 & $\mathrm{mg} / \mathrm{L}$ & & $5 / 15 / 2007$ & $6 / 8 / 2007$ & 2 \\
\hline SW846-6010B & METAL & Sodium & MW262 & 47 & $\mathrm{mg} / \mathrm{L}$ & & $5 / 16 / 2007$ & $6 / 8 / 2007$ & 2 \\
\hline SW846-6010B & METAL & Sodium & MW340 & 44.1 & $\mathrm{mg} / \mathrm{L}$ & & $5 / 23 / 2007$ & $6 / 8 / 2007$ & 2 \\
\hline SW846-6010B & METAL & Sodium & MW381 & 33.7 & $\mathrm{mg} / \mathrm{L}$ & & $5 / 22 / 2007$ & $6 / 8 / 2007$ & 2 \\
\hline SW846-6010B & METAL & Sodium & MW66 & 16.2 & $\mathrm{mg} / \mathrm{L}$ & & $5 / 15 / 2007$ & $6 / 8 / 2007$ & 2 \\
\hline SW846-6010B & METAL & Sodium & QC & 2 & $\mathrm{mg} / \mathrm{L}$ & $U$ & $5 / 22 / 2007$ & $6 / 8 / 2007$ & 2 \\
\hline SW846-6010B & METAL & Sodium & $\mathrm{QC}$ & 2 & $\mathrm{mg} / \mathrm{L}$ & $U$ & $5 / 22 / 2007$ & $6 / 8 / 2007$ & 2 \\
\hline SW846-6010B & METAL-D & Copper, Dissolved & MW125 & 0.025 & $\mathrm{mg} / \mathrm{L}$ & $\mathrm{BU}$ & $5 / 21 / 2007$ & $6 / 8 / 2007$ & 0.025 \\
\hline SW846-6010B & METAL-D & Copper, Dissolved & MW168 & 0.025 & $\mathrm{mg} / \mathrm{L}$ & $\mathrm{BU}$ & $5 / 16 / 2007$ & $6 / 8 / 2007$ & 0.025 \\
\hline SW846-6010B & METAL-D & Copper, Dissolved & MW185 & 0.025 & $\mathrm{mg} / \mathrm{L}$ & $\mathrm{BU}$ & $5 / 23 / 2007$ & $6 / 8 / 2007$ & 0.025 \\
\hline SW846-6010B & METAL-D & Copper, Dissolved & MW194 & 0.025 & $\mathrm{mg} / \mathrm{L}$ & $\mathrm{BU}$ & $5 / 17 / 2007$ & $6 / 8 / 2007$ & 0.025 \\
\hline SW846-6010B & METAL-D & Copper, Dissolved & MW197 & 0.025 & $\mathrm{mg} / \mathrm{L}$ & $\mathrm{BU}$ & $5 / 21 / 2007$ & $6 / 8 / 2007$ & 0.025 \\
\hline SW846-6010B & METAL-D & Copper, Dissolved & MW236 & 0.025 & $\mathrm{mg} / \mathrm{L}$ & $\mathrm{BU}$ & $5 / 22 / 2007$ & $6 / 8 / 2007$ & 0.025 \\
\hline SW846-6010B & METAL-D & Copper, Dissolved & MW236 & 0.025 & $\mathrm{mg} / \mathrm{L}$ & $\mathrm{BU}$ & $5 / 22 / 2007$ & $6 / 8 / 2007$ & 0.025 \\
\hline SW846-6010B & METAL-D & Copper, Dissolved & MW242 & 0.025 & $\mathrm{mg} / \mathrm{L}$ & $\mathrm{BU}$ & $5 / 17 / 2007$ & $6 / 8 / 2007$ & 0.025 \\
\hline SW846-6010B & METAL-D & Copper, Dissolved & MW243 & 0.025 & $\mathrm{mg} / \mathrm{L}$ & $\mathrm{BU}$ & $5 / 15 / 2007$ & $6 / 8 / 2007$ & 0.025 \\
\hline SW846-6010B & METAL-D & Copper, Dissolved & MW262 & 0.025 & $\mathrm{mg} / \mathrm{L}$ & $\mathrm{BU}$ & $5 / 16 / 2007$ & $6 / 8 / 2007$ & 0.025 \\
\hline SW846-6010B & METAL-D & Copper, Dissolved & MW340 & 0.025 & $\mathrm{mg} / \mathrm{L}$ & $\mathrm{BU}$ & $5 / 23 / 2007$ & $6 / 8 / 2007$ & 0.025 \\
\hline SW846-6010B & METAL-D & Copper, Dissolved & MW381 & 0.025 & $\mathrm{mg} / \mathrm{L}$ & $\mathrm{BU}$ & $5 / 22 / 2007$ & $6 / 8 / 2007$ & 0.025 \\
\hline SW846-6010B & METAL-D & Copper, Dissolved & MW66 & 0.025 & $\mathrm{mg} / \mathrm{L}$ & $\mathrm{BU}$ & $5 / 15 / 2007$ & $6 / 8 / 2007$ & 0.025 \\
\hline SW846-8260 & VOA & 1,1,1-Trichloroethane & MW125 & 25 & ug/L & $U$ & $5 / 21 / 2007$ & $6 / 1 / 2007$ & 25 \\
\hline SW846-8260 & VOA & 1,1,1-Trichloroethane & MW168 & 5 & $\mathrm{ug} / \mathrm{L}$ & $U$ & $5 / 16 / 2007$ & $5 / 30 / 2007$ & 5 \\
\hline SW846-8260 & VOA & 1,1,1-Trichloroethane & MW185 & 120 & $\mathrm{ug} / \mathrm{L}$ & $U$ & $5 / 23 / 2007$ & $6 / 5 / 2007$ & 120 \\
\hline SW846-8260 & VOA & 1,1,1-Trichloroethane & MW194 & 5 & $\mathrm{ug} / \mathrm{L}$ & $U$ & $5 / 17 / 2007$ & $5 / 30 / 2007$ & 5 \\
\hline SW846-8260 & VOA & 1,1,1-Trichloroethane & MW197 & 5 & $\mathrm{ug} / \mathrm{L}$ & $U$ & $5 / 21 / 2007$ & $6 / 1 / 2007$ & 5 \\
\hline SW846-8260 & VOA & 1,1,1-Trichloroethane & MW236 & 5 & ug/L & $U$ & $5 / 22 / 2007$ & $6 / 5 / 2007$ & 5 \\
\hline SW846-8260 & VOA & 1,1,1-Trichloroethane & MW236 & 5 & ug/L & $\mathrm{U}$ & $5 / 22 / 2007$ & $6 / 5 / 2007$ & 5 \\
\hline SW846-8260 & VOA & 1,1,1-Trichloroethane & MW242 & 5 & ug/L & $U$ & $5 / 17 / 2007$ & $5 / 30 / 2007$ & 5 \\
\hline SW846-8260 & VOA & 1,1,1-Trichloroethane & MW243 & 5 & ug/L & $U$ & $5 / 15 / 2007$ & $5 / 29 / 2007$ & 5 \\
\hline SW846-8260 & VOA & $1,1,1$-Trichloroethane & MW262 & 50 & $\mathrm{ug} / \mathrm{L}$ & $\mathrm{U}$ & $5 / 16 / 2007$ & $5 / 30 / 2007$ & 50 \\
\hline SW846-8260 & VOA & 1,1,1-Trichloroethane & MW340 & 250 & $\mathrm{ug} / \mathrm{L}$ & $U$ & $5 / 23 / 2007$ & $6 / 5 / 2007$ & 250 \\
\hline SW846-8260 & VOA & 1,1,1-Trichloroethane & MW381 & 5 & $\mathrm{ug} / \mathrm{L}$ & $U$ & $5 / 22 / 2007$ & $6 / 5 / 2007$ & 5 \\
\hline SW846-8260 & VOA & 1,1,1-Trichloroethane & MW66 & 100 & $\mathrm{ug} / \mathrm{L}$ & $U$ & $5 / 15 / 2007$ & $5 / 29 / 2007$ & 100 \\
\hline SW846-8260 & VOA & 1,1,1-Trichloroethane & QC & 5 & $\mathrm{ug} / \mathrm{L}$ & $U$ & $5 / 17 / 2007$ & $5 / 30 / 2007$ & 5 \\
\hline SW846-8260 & VOA & 1,1,1-Trichloroethane & QC & 5 & $\mathrm{ug} / \mathrm{L}$ & $U$ & $5 / 21 / 2007$ & $6 / 1 / 2007$ & 5 \\
\hline SW846-8260 & VOA & 1,1,1-Trichloroethane & $\mathrm{QC}$ & 5 & $\mathrm{ug} / \mathrm{L}$ & $U$ & $5 / 22 / 2007$ & $6 / 5 / 2007$ & 5 \\
\hline SW846-8260 & VOA & 1,1,1-Trichloroethane & QC & 5 & $\mathrm{ug} / \mathrm{L}$ & $U$ & $5 / 15 / 2007$ & $5 / 29 / 2007$ & 5 \\
\hline SW846-8260 & VOA & 1,1,1-Trichloroethane & $\mathrm{QC}$ & 5 & $\mathrm{ug} / \mathrm{L}$ & $\mathrm{U}$ & $5 / 16 / 2007$ & $5 / 30 / 2007$ & 5 \\
\hline SW846-8260 & VOA & 1,1,1-Trichloroethane & QC & 5 & $\mathrm{ug} / \mathrm{L}$ & $U$ & $5 / 22 / 2007$ & $6 / 5 / 2007$ & 5 \\
\hline SW846-8260 & VOA & 1,1,1-Trichloroethane & QC & 5 & $\mathrm{ug} / \mathrm{L}$ & $U$ & $5 / 22 / 2007$ & $6 / 5 / 2007$ & 5 \\
\hline SW846-8260 & VOA & 1,1,1-Trichloroethane & QC & 5 & $\mathrm{ug} / \mathrm{L}$ & $U$ & $5 / 23 / 2007$ & $6 / 5 / 2007$ & 5 \\
\hline SW846-8260 & VOA & 1,1,2,2-Tetrachloroethane & MW125 & 25 & $\mathrm{ug} / \mathrm{L}$ & $U$ & $5 / 21 / 2007$ & $6 / 1 / 2007$ & 25 \\
\hline SW846-8260 & VOA & $1,1,2,2$-Tetrachloroethane & MW168 & 5 & $\mathrm{ug} / \mathrm{L}$ & $U$ & $5 / 16 / 2007$ & $5 / 30 / 2007$ & 5 \\
\hline SW846-8260 & VOA & 1,1,2,2-Tetrachloroethane & MW185 & 120 & $\mathrm{ug} / \mathrm{L}$ & $U$ & $5 / 23 / 2007$ & $6 / 5 / 2007$ & 120 \\
\hline SW846-8260 & VOA & 1,1,2,2-Tetrachloroethane & MW194 & 5 & $\mathrm{ug} / \mathrm{L}$ & $U$ & $5 / 17 / 2007$ & $5 / 30 / 2007$ & 5 \\
\hline SW846-8260 & VOA & 1,1,2,2-Tetrachloroethane & MW197 & 5 & $\mathrm{ug} / \mathrm{L}$ & $U$ & $5 / 21 / 2007$ & $6 / 1 / 2007$ & 5 \\
\hline SW846-8260 & VOA & 1,1,2,2-Tetrachloroethane & MW236 & 5 & $\mathrm{ug} / \mathrm{L}$ & $U$ & $5 / 22 / 2007$ & $6 / 5 / 2007$ & 5 \\
\hline SW846-8260 & VOA & 1,1,2,2-Tetrachloroethane & MW236 & 5 & $\mathrm{ug} / \mathrm{L}$ & $U$ & $5 / 22 / 2007$ & $6 / 5 / 2007$ & 5 \\
\hline SW846-8260 & VOA & $1,1,2,2$-Tetrachloroethane & MW242 & 5 & ug/L & $\mathrm{U}$ & $5 / 17 / 2007$ & $5 / 30 / 2007$ & 5 \\
\hline SW846-8260 & VOA & 1,1,2,2-Tetrachloroethane & MW243 & 5 & $\mathrm{ug} / \mathrm{L}$ & $U$ & $5 / 15 / 2007$ & $5 / 29 / 2007$ & 5 \\
\hline SW846-8260 & VOA & 1,1,2,2-Tetrachloroethane & MW262 & 50 & $\mathrm{ug} / \mathrm{L}$ & $U$ & $5 / 16 / 2007$ & $5 / 30 / 2007$ & 50 \\
\hline SW846-8260 & VOA & 1,1,2,2-Tetrachloroethane & MW340 & 250 & $\mathrm{ug} / \mathrm{L}$ & $U$ & $5 / 23 / 2007$ & $6 / 5 / 2007$ & 250 \\
\hline SW846-8260 & VOA & 1,1,2,2-Tetrachloroethane & MW381 & 5 & $\mathrm{ug} / \mathrm{L}$ & $U$ & $5 / 22 / 2007$ & $6 / 5 / 2007$ & 5 \\
\hline SW846-8260 & VOA & $1,1,2,2$-Tetrachloroethane & MW66 & 100 & $\mathrm{ug} / \mathrm{L}$ & $\mathrm{U}$ & $5 / 15 / 2007$ & $5 / 29 / 2007$ & 100 \\
\hline SW846-8260 & VOA & 1,1,2,2-Tetrachloroethane & QC & 5 & $\mathrm{ug} / \mathrm{L}$ & $U$ & $5 / 17 / 2007$ & $5 / 30 / 2007$ & 5 \\
\hline SW846-8260 & VOA & $1,1,2,2$-Tetrachloroethane & $\mathrm{QC}$ & 5 & $\mathrm{ug} / \mathrm{L}$ & $U$ & $5 / 21 / 2007$ & $6 / 1 / 2007$ & 5 \\
\hline SW846-8260 & VOA & 1,1,2,2-Tetrachloroethane & QC & 5 & $\mathrm{ug} / \mathrm{L}$ & $U$ & $5 / 22 / 2007$ & $6 / 5 / 2007$ & 5 \\
\hline SW846-8260 & VOA & 1,1,2,2-Tetrachloroethane & QC & 5 & $\mathrm{ug} / \mathrm{L}$ & $U$ & $5 / 15 / 2007$ & $5 / 29 / 2007$ & 5 \\
\hline SW846-8260 & VOA & 1,1,2,2-Tetrachloroethane & QC & 5 & $\mathrm{ug} / \mathrm{L}$ & $\mathrm{U}$ & $5 / 16 / 2007$ & $5 / 30 / 2007$ & 5 \\
\hline SW846-8260 & VOA & $1,1,2,2$-Tetrachloroethane & $\mathrm{QC}$ & 5 & ug/L & $U$ & $5 / 22 / 2007$ & $6 / 5 / 2007$ & 5 \\
\hline SW846-8260 & VOA & 1,1,2,2-Tetrachloroethane & QC & 5 & $\mathrm{ug} / \mathrm{L}$ & $U$ & $5 / 22 / 2007$ & $6 / 5 / 2007$ & 5 \\
\hline SW846-8260 & VOA & 1,1,2,2-Tetrachloroethane & QC & 5 & $\mathrm{ug} / \mathrm{L}$ & $U$ & $5 / 23 / 2007$ & $6 / 5 / 2007$ & 5 \\
\hline SW846-8260 & VOA & 1,1,2-Trichloroethane & MW125 & 25 & $\mathrm{ug} / \mathrm{L}$ & $U$ & $5 / 21 / 2007$ & $6 / 1 / 2007$ & 25 \\
\hline SW846-8260 & VOA & 1,1,2-Trichloroethane & MW168 & 5 & $\mathrm{ug} / \mathrm{L}$ & $U$ & $5 / 16 / 2007$ & $5 / 30 / 2007$ & 5 \\
\hline SW846-8260 & VOA & 1,1,2-Trichloroethane & MW185 & 120 & $\mathrm{ug} / \mathrm{L}$ & $U$ & $5 / 23 / 2007$ & $6 / 5 / 2007$ & 120 \\
\hline SW846-8260 & VOA & 1,1,2-Trichloroethane & MW194 & 5 & $\mathrm{ug} / \mathrm{L}$ & $U$ & $5 / 17 / 2007$ & $5 / 30 / 2007$ & 5 \\
\hline SW846-8260 & VOA & 1,1,2-Trichloroethane & MW197 & 5 & $\mathrm{ug} / \mathrm{L}$ & $U$ & $5 / 21 / 2007$ & $6 / 1 / 2007$ & 5 \\
\hline SW846-8260 & VOA & 1,1,2-Trichloroethane & MW236 & 5 & $\mathrm{ug} / \mathrm{L}$ & $U$ & $5 / 22 / 2007$ & $6 / 5 / 2007$ & 5 \\
\hline
\end{tabular}




\begin{tabular}{|c|c|c|c|c|c|c|c|c|c|}
\hline Method & AnaType & Chemical Name & Station & Results & Units & $\begin{array}{c}\text { Result } \\
\text { Qualifier }\end{array}$ & Date Collected & $\begin{array}{c}\text { Date } \\
\text { Analyzed }\end{array}$ & $\begin{array}{l}\text { Detection } \\
\text { Limit }\end{array}$ \\
\hline SW846-8260 & VOA & 1,1,2-Trichloroethane & MW236 & 5 & $u g / L$ & U & $5 / 22 / 2007$ & $6 / 5 / 2007$ & 5 \\
\hline SW846-8260 & VOA & 1,1,2-Trichloroethane & MW242 & 5 & $\mathrm{ug} / \mathrm{L}$ & $u$ & $5 / 17 / 2007$ & $5 / 30 / 2007$ & 5 \\
\hline SW846-8260 & VOA & 1,1,2-Trichloroethane & MW243 & 5 & $\mathrm{ug} / \mathrm{L}$ & $\mathrm{u}$ & $5 / 15 / 2007$ & $5 / 29 / 2007$ & 5 \\
\hline SW846-8260 & VOA & 1,1,2-Trichloroethane & MW262 & 50 & $\mathrm{ug} / \mathrm{L}$ & $u$ & $5 / 16 / 2007$ & $5 / 30 / 2007$ & 50 \\
\hline SW846-8260 & VOA & 1,1,2-Trichloroethane & MW340 & 250 & $\mathrm{ug} / \mathrm{L}$ & $\mathrm{u}$ & $5 / 23 / 2007$ & $6 / 5 / 2007$ & 250 \\
\hline SW846-8260 & VOA & 1,1,2-Trichloroethane & MW381 & 5 & $\mathrm{ug} / \mathrm{L}$ & $u$ & $5 / 22 / 2007$ & $6 / 5 / 2007$ & 5 \\
\hline SW846-8260 & VOA & 1,1,2-Trichloroethane & MW66 & 100 & $\mathrm{ug} / \mathrm{L}$ & $\mathrm{U}$ & $5 / 15 / 2007$ & $5 / 29 / 2007$ & 100 \\
\hline SW846-8260 & VOA & 1,1,2-Trichloroethane & $\mathrm{QC}$ & 5 & $\mathrm{ug} / \mathrm{L}$ & $\mathrm{U}$ & $5 / 16 / 2007$ & $5 / 30 / 2007$ & 5 \\
\hline SW846-8260 & VOA & 1,1,2-Trichloroethane & $\mathrm{QC}$ & 5 & $\mathrm{ug} / \mathrm{L}$ & $\mathrm{U}$ & $5 / 17 / 2007$ & $5 / 30 / 2007$ & 5 \\
\hline SW846-8260 & VOA & 1,1,2-Trichloroethane & $\mathrm{QC}$ & 5 & $\mathrm{ug} / \mathrm{L}$ & $\mathrm{U}$ & $5 / 21 / 2007$ & $6 / 1 / 2007$ & 5 \\
\hline SW846-8260 & VOA & 1,1,2-Trichloroethane & $\mathrm{QC}$ & 5 & $\mathrm{ug} / \mathrm{L}$ & u & $5 / 15 / 2007$ & $5 / 29 / 2007$ & 5 \\
\hline SW846-8260 & VOA & 1,1,2-Trichloroethane & $\mathrm{QC}$ & 5 & $\mathrm{ug} / \mathrm{L}$ & $\mathrm{U}$ & $5 / 22 / 2007$ & $6 / 5 / 2007$ & 5 \\
\hline SW846-8260 & VOA & 1,1,2-Trichloroethane & $\mathrm{QC}$ & 5 & ug/L & $u$ & $5 / 22 / 2007$ & $6 / 5 / 2007$ & 5 \\
\hline SW846-8260 & VOA & 1,1,2-Trichloroethane & QC & 5 & $\mathrm{ug} / \mathrm{L}$ & $u$ & $5 / 22 / 2007$ & $6 / 5 / 2007$ & 5 \\
\hline SW846-8260 & VOA & 1,1,2-Trichloroethane & QC & 5 & $\mathrm{ug} / \mathrm{L}$ & $\mathrm{U}$ & $5 / 23 / 2007$ & $6 / 5 / 2007$ & 5 \\
\hline SW846-8260 & VOA & 1,1-Dichloroethane & MW125 & 25 & $\mathrm{ug} / \mathrm{L}$ & $\mathrm{U}$ & $5 / 21 / 2007$ & $6 / 1 / 2007$ & 25 \\
\hline SW846-8260 & VOA & 1,1-Dichloroethane & MW168 & 5 & $\mathrm{ug} / \mathrm{L}$ & $\mathrm{U}$ & $5 / 16 / 2007$ & $5 / 30 / 2007$ & 5 \\
\hline SW846-8260 & VOA & 1,1-Dichloroethane & MW185 & 120 & $\mathrm{ug} / \mathrm{L}$ & $\mathrm{U}$ & $5 / 23 / 2007$ & $6 / 5 / 2007$ & 120 \\
\hline SW846-8260 & VOA & 1,1-Dichloroethane & MW194 & 5 & $\mathrm{ug} / \mathrm{L}$ & $\mathrm{U}$ & $5 / 17 / 2007$ & $5 / 30 / 2007$ & 5 \\
\hline SW846-8260 & VOA & 1,1-Dichloroethane & MW197 & 5 & $\mathrm{ug} / \mathrm{L}$ & u & $5 / 21 / 2007$ & $6 / 1 / 2007$ & 5 \\
\hline SW846-8260 & VOA & 1,1-Dichloroethane & MW236 & 5 & $\mathrm{ug} / \mathrm{L}$ & U & $5 / 22 / 2007$ & $6 / 5 / 2007$ & 5 \\
\hline SW846-8260 & VOA & 1,1-Dichloroethane & MW236 & 5 & $\mathrm{ug} / \mathrm{L}$ & $\mathrm{U}$ & $5 / 22 / 2007$ & $6 / 5 / 2007$ & 5 \\
\hline SW846-8260 & VOA & 1,1-Dichloroethane & MW242 & 5 & $\mathrm{ug} / \mathrm{L}$ & $u$ & $5 / 17 / 2007$ & $5 / 30 / 2007$ & 5 \\
\hline SW846-8260 & VOA & 1,1-Dichloroethane & MW243 & 5 & $\mathrm{ug} / \mathrm{L}$ & $\mathrm{u}$ & $5 / 15 / 2007$ & $5 / 29 / 2007$ & 5 \\
\hline SW846-8260 & VOA & 1,1-Dichloroethane & MW262 & 50 & $\mathrm{ug} / \mathrm{L}$ & $u$ & $5 / 16 / 2007$ & $5 / 30 / 2007$ & 50 \\
\hline SW846-8260 & VOA & 1,1-Dichloroethane & MW340 & 250 & $\mathrm{ug} / \mathrm{L}$ & $\mathrm{U}$ & $5 / 23 / 2007$ & $6 / 5 / 2007$ & 250 \\
\hline SW846-8260 & VOA & 1,1-Dichloroethane & MW381 & 5 & $\mathrm{ug} / \mathrm{L}$ & $\mathrm{U}$ & $5 / 22 / 2007$ & $6 / 5 / 2007$ & 5 \\
\hline SW846-8260 & VOA & 1,1-Dichloroethane & MW66 & 100 & $u g / L$ & $\mathrm{U}$ & $5 / 15 / 2007$ & $5 / 29 / 2007$ & 100 \\
\hline SW846-8260 & VOA & 1,1-Dichloroethane & $\mathrm{QC}$ & 5 & $u g / L$ & $\mathrm{U}$ & $5 / 17 / 2007$ & $5 / 30 / 2007$ & 5 \\
\hline SW846-8260 & VOA & 1,1-Dichloroethane & $\mathrm{QC}$ & 5 & $\mathrm{ug} / \mathrm{L}$ & $\mathrm{u}$ & $5 / 21 / 2007$ & 6/1/2007 & 5 \\
\hline SW846-8260 & VOA & 1,1-Dichloroethane & $\mathrm{QC}$ & 5 & $\mathrm{ug} / \mathrm{L}$ & $\mathrm{u}$ & $5 / 22 / 2007$ & $6 / 5 / 2007$ & 5 \\
\hline SW846-8260 & VOA & 1,1-Dichloroethane & $\mathrm{QC}$ & 5 & ug/L & u & $5 / 15 / 2007$ & $5 / 29 / 2007$ & 5 \\
\hline SW846-8260 & VOA & 1,1-Dichloroethane & $\mathrm{QC}$ & 5 & $\mathrm{ug} / \mathrm{L}$ & $\mathrm{U}$ & $5 / 16 / 2007$ & $5 / 30 / 2007$ & 5 \\
\hline SW846-8260 & VOA & 1,1-Dichloroethane & $\mathrm{QC}$ & 5 & $u g / L$ & $\mathrm{U}$ & $5 / 22 / 2007$ & $6 / 5 / 2007$ & 5 \\
\hline SW846-8260 & VOA & 1,1-Dichloroethane & $\mathrm{QC}$ & 5 & $\mathrm{ug} / \mathrm{L}$ & $u$ & $5 / 22 / 2007$ & $6 / 5 / 2007$ & 5 \\
\hline SW846-8260 & VOA & 1,1-Dichloroethane & $\mathrm{QC}$ & 5 & $\mathrm{ug} / \mathrm{L}$ & $\mathrm{U}$ & $5 / 23 / 2007$ & $6 / 5 / 2007$ & 5 \\
\hline SW846-8260 & VOA & 1,1-Dichloroethene & MW125 & 25 & $u g / L$ & $\mathrm{U}$ & $5 / 21 / 2007$ & $6 / 1 / 2007$ & 25 \\
\hline SW846-8260 & VOA & 1,1-Dichloroethene & MW168 & 5 & $\mathrm{ug} / \mathrm{L}$ & $\mathrm{U}$ & $5 / 16 / 2007$ & $5 / 30 / 2007$ & 5 \\
\hline SW846-8260 & VOA & 1,1-Dichloroethene & MW185 & 120 & $\mathrm{ug} / \mathrm{L}$ & $\mathrm{U}$ & $5 / 23 / 2007$ & 6/5/2007 & 120 \\
\hline SW846-8260 & VOA & 1,1-Dichloroethene & MW194 & 5 & $\mathrm{ug} / \mathrm{L}$ & $\mathrm{U}$ & $5 / 17 / 2007$ & $5 / 30 / 2007$ & 5 \\
\hline SW846-8260 & VOA & 1,1-Dichloroethene & MW197 & 5 & $u g / L$ & u & $5 / 21 / 2007$ & $6 / 1 / 2007$ & 5 \\
\hline SW846-8260 & VOA & 1,1-Dichloroethene & MW236 & 5 & $u g / L$ & u & $5 / 22 / 2007$ & $6 / 5 / 2007$ & 5 \\
\hline SW846-8260 & VOA & 1,1-Dichloroethene & MW236 & 5 & $\mathrm{ug} / \mathrm{L}$ & $\mathrm{U}$ & $5 / 22 / 2007$ & $6 / 5 / 2007$ & 5 \\
\hline SW846-8260 & VOA & 1,1-Dichloroethene & MW242 & 5 & $\mathrm{ug} / \mathrm{L}$ & $u$ & $5 / 17 / 2007$ & $5 / 30 / 2007$ & 5 \\
\hline SW846-8260 & VOA & 1,1-Dichloroethene & MW243 & 5 & $\mathrm{ug} / \mathrm{L}$ & $u$ & $5 / 15 / 2007$ & $5 / 29 / 2007$ & 5 \\
\hline SW846-8260 & VOA & 1,1-Dichloroethene & MW262 & 50 & $u g / L$ & $u$ & $5 / 16 / 2007$ & $5 / 30 / 2007$ & 50 \\
\hline SW846-8260 & VOA & 1,1-Dichloroethene & MW340 & 250 & $\mathrm{ug} / \mathrm{L}$ & $\mathrm{U}$ & $5 / 23 / 2007$ & $6 / 5 / 2007$ & 250 \\
\hline SW846-8260 & VOA & 1,1-Dichloroethene & MW381 & 5 & $u g / L$ & u & $5 / 22 / 2007$ & $6 / 5 / 2007$ & 5 \\
\hline SW846-8260 & VOA & 1,1-Dichloroethene & MW66 & 100 & $u g / L$ & $\mathrm{U}$ & $5 / 15 / 2007$ & $5 / 29 / 2007$ & 100 \\
\hline SW846-8260 & VOA & 1,1-Dichloroethene & $\mathrm{QC}$ & 5 & $u g / L$ & $\mathrm{U}$ & $5 / 16 / 2007$ & $5 / 30 / 2007$ & 5 \\
\hline SW846-8260 & VOA & 1,1-Dichloroethene & $\mathrm{QC}$ & 5 & $\mathrm{ug} / \mathrm{L}$ & $\mathrm{u}$ & $5 / 17 / 2007$ & $5 / 30 / 2007$ & 5 \\
\hline SW846-8260 & VOA & 1,1-Dichloroethene & $\mathrm{QC}$ & 5 & $\mathrm{ug} / \mathrm{L}$ & $\mathrm{u}$ & $5 / 21 / 2007$ & $6 / 1 / 2007$ & 5 \\
\hline SW846-8260 & VOA & 1,1-Dichloroethene & $\mathrm{QC}$ & 5 & $\mathrm{ug} / \mathrm{L}$ & $\mathrm{u}$ & $5 / 15 / 2007$ & $5 / 29 / 2007$ & 5 \\
\hline SW846-8260 & VOA & 1,1-Dichloroethene & $\mathrm{QC}$ & 5 & $u g / L$ & $\mathrm{U}$ & $5 / 22 / 2007$ & $6 / 5 / 2007$ & 5 \\
\hline SW846-8260 & VOA & 1,1-Dichloroethene & QC & 5 & $u g / L$ & $\mathrm{U}$ & $5 / 22 / 2007$ & $6 / 5 / 2007$ & 5 \\
\hline SW846-8260 & VOA & 1,1-Dichloroethene & $\mathrm{QC}$ & 5 & $u g / L$ & $u$ & $5 / 22 / 2007$ & $6 / 5 / 2007$ & 5 \\
\hline SW846-8260 & VOA & 1,1-Dichloroethene & QC & 5 & $u g / L$ & $\mathrm{U}$ & $5 / 23 / 2007$ & $6 / 5 / 2007$ & 5 \\
\hline SW846-8260 & VOA & 1,2-Dichloroethane & MW125 & 25 & $u g / L$ & $u$ & $5 / 21 / 2007$ & $6 / 1 / 2007$ & 25 \\
\hline SW846-8260 & VOA & 1,2-Dichloroethane & MW168 & 5 & $\mathrm{ug} / \mathrm{L}$ & $\mathrm{u}$ & $5 / 16 / 2007$ & $5 / 30 / 2007$ & 5 \\
\hline SW846-8260 & VOA & 1,2-Dichloroethane & MW185 & 120 & $\mathrm{ug} / \mathrm{L}$ & $\mathrm{U}$ & $5 / 23 / 2007$ & $6 / 5 / 2007$ & 120 \\
\hline SW846-8260 & VOA & 1,2-Dichloroethane & MW194 & 5 & $\mathrm{ug} / \mathrm{L}$ & $u$ & $5 / 17 / 2007$ & $5 / 30 / 2007$ & 5 \\
\hline SW846-8260 & VOA & 1,2-Dichloroethane & MW197 & 5 & $u g / L$ & $\mathrm{u}$ & $5 / 21 / 2007$ & $6 / 1 / 2007$ & 5 \\
\hline SW846-8260 & VOA & 1,2-Dichloroethane & MW236 & 5 & $u g / L$ & $u$ & $5 / 22 / 2007$ & $6 / 5 / 2007$ & 5 \\
\hline SW846-8260 & VOA & 1,2-Dichloroethane & MW236 & 5 & $u g / L$ & $\mathrm{U}$ & $5 / 22 / 2007$ & $6 / 5 / 2007$ & 5 \\
\hline SW846-8260 & VOA & 1,2-Dichloroethane & MW242 & 5 & $u g / L$ & $u$ & $5 / 17 / 2007$ & $5 / 30 / 2007$ & 5 \\
\hline SW846-8260 & VOA & 1,2-Dichloroethane & MW243 & 5 & $\mathrm{ug} / \mathrm{L}$ & $u$ & $5 / 15 / 2007$ & $5 / 29 / 2007$ & 5 \\
\hline SW846-8260 & VOA & 1,2-Dichloroethane & MW262 & 50 & $u g / L$ & $u$ & $5 / 16 / 2007$ & $5 / 30 / 2007$ & 50 \\
\hline SW846-8260 & VOA & 1,2-Dichloroethane & MW340 & 250 & $u g / L$ & $\mathrm{U}$ & $5 / 23 / 2007$ & $6 / 5 / 2007$ & 250 \\
\hline SW846-8260 & VOA & 1,2-Dichloroethane & MW381 & 5 & $u g / L$ & u & $5 / 22 / 2007$ & $6 / 5 / 2007$ & 5 \\
\hline
\end{tabular}




\begin{tabular}{|c|c|c|c|c|c|c|c|c|c|}
\hline Method & AnaType & Chemical Name & Station & Results & Units & $\begin{array}{c}\text { Result } \\
\text { Qualifier }\end{array}$ & Date Collected & $\begin{array}{c}\text { Date } \\
\text { Analyzed }\end{array}$ & $\begin{array}{l}\text { Detection } \\
\text { Limit }\end{array}$ \\
\hline SW846-8260 & VOA & 1,2-Dichloroethane & MW66 & 100 & $u g / L$ & $\mathrm{U}$ & $5 / 15 / 2007$ & $5 / 29 / 2007$ & 100 \\
\hline SW846-8260 & VOA & 1,2-Dichloroethane & $\mathrm{QC}$ & 5 & $\mathrm{ug} / \mathrm{L}$ & $u$ & $5 / 16 / 2007$ & $5 / 30 / 2007$ & 5 \\
\hline SW846-8260 & VOA & 1,2-Dichloroethane & $\mathrm{QC}$ & 5 & $\mathrm{ug} / \mathrm{L}$ & $\mathrm{u}$ & $5 / 17 / 2007$ & $5 / 30 / 2007$ & 5 \\
\hline SW846-8260 & VOA & 1,2-Dichloroethane & $\mathrm{QC}$ & 5 & $\mathrm{ug} / \mathrm{L}$ & $u$ & $5 / 21 / 2007$ & $6 / 1 / 2007$ & 5 \\
\hline SW846-8260 & VOA & 1,2-Dichloroethane & $\mathrm{QC}$ & 5 & $\mathrm{ug} / \mathrm{L}$ & $\mathrm{u}$ & $5 / 15 / 2007$ & $5 / 29 / 2007$ & 5 \\
\hline SW846-8260 & VOA & 1,2-Dichloroethane & QC & 5 & $\mathrm{ug} / \mathrm{L}$ & $u$ & $5 / 22 / 2007$ & $6 / 5 / 2007$ & 5 \\
\hline SW846-8260 & VOA & 1,2-Dichloroethane & QC & 5 & $\mathrm{ug} / \mathrm{L}$ & $\mathrm{U}$ & $5 / 22 / 2007$ & $6 / 5 / 2007$ & 5 \\
\hline SW846-8260 & VOA & 1,2-Dichloroethane & QC & 5 & $\mathrm{ug} / \mathrm{L}$ & $\mathrm{U}$ & $5 / 22 / 2007$ & $6 / 5 / 2007$ & 5 \\
\hline SW846-8260 & VOA & 1,2-Dichloroethane & QC & 5 & $\mathrm{ug} / \mathrm{L}$ & $u$ & $5 / 23 / 2007$ & $6 / 5 / 2007$ & 5 \\
\hline SW846-8260 & VOA & 1,2-Dichloropropane & MW125 & 25 & $\mathrm{ug} / \mathrm{L}$ & $\mathrm{u}$ & $5 / 21 / 2007$ & $6 / 1 / 2007$ & 25 \\
\hline SW846-8260 & VOA & 1,2-Dichloropropane & MW168 & 5 & $\mathrm{ug} / \mathrm{L}$ & u & $5 / 16 / 2007$ & $5 / 30 / 2007$ & 5 \\
\hline SW846-8260 & VOA & 1,2-Dichloropropane & MW185 & 120 & $\mathrm{ug} / \mathrm{L}$ & $\mathrm{U}$ & $5 / 23 / 2007$ & $6 / 5 / 2007$ & 120 \\
\hline SW846-8260 & VOA & 1,2-Dichloropropane & MW194 & 5 & ug/L & $\mathrm{U}$ & $5 / 17 / 2007$ & $5 / 30 / 2007$ & 5 \\
\hline SW846-8260 & VOA & 1,2-Dichloropropane & MW197 & 5 & $\mathrm{ug} / \mathrm{L}$ & $\mathrm{u}$ & $5 / 21 / 2007$ & $6 / 1 / 2007$ & 5 \\
\hline SW846-8260 & VOA & 1,2-Dichloropropane & MW236 & 5 & $\mathrm{ug} / \mathrm{L}$ & $\mathrm{U}$ & $5 / 22 / 2007$ & $6 / 5 / 2007$ & 5 \\
\hline SW846-8260 & VOA & 1,2-Dichloropropane & MW236 & 5 & $\mathrm{ug} / \mathrm{L}$ & $\mathrm{U}$ & $5 / 22 / 2007$ & $6 / 5 / 2007$ & 5 \\
\hline SW846-8260 & VOA & 1,2-Dichloropropane & MW242 & 5 & $\mathrm{ug} / \mathrm{L}$ & $\mathrm{U}$ & $5 / 17 / 2007$ & $5 / 30 / 2007$ & 5 \\
\hline SW846-8260 & VOA & 1,2-Dichloropropane & MW243 & 5 & $\mathrm{ug} / \mathrm{L}$ & $\mathrm{U}$ & $5 / 15 / 2007$ & $5 / 29 / 2007$ & 5 \\
\hline SW846-8260 & VOA & 1,2-Dichloropropane & MW262 & 50 & $\mathrm{ug} / \mathrm{L}$ & $\mathrm{U}$ & $5 / 16 / 2007$ & $5 / 30 / 2007$ & 50 \\
\hline SW846-8260 & VOA & 1,2-Dichloropropane & MW340 & 250 & $\mathrm{ug} / \mathrm{L}$ & $\mathrm{U}$ & $5 / 23 / 2007$ & 6/5/2007 & 250 \\
\hline SW846-8260 & VOA & 1,2-Dichloropropane & MW381 & 5 & $\mathrm{ug} / \mathrm{L}$ & $\mathrm{U}$ & $5 / 22 / 2007$ & $6 / 5 / 2007$ & 5 \\
\hline SW846-8260 & VOA & 1,2-Dichloropropane & MW66 & 100 & $\mathrm{ug} / \mathrm{L}$ & $\mathrm{u}$ & $5 / 15 / 2007$ & $5 / 29 / 2007$ & 100 \\
\hline SW846-8260 & VOA & 1,2-Dichloropropane & $\mathrm{QC}$ & 5 & $\mathrm{ug} / \mathrm{L}$ & $u$ & $5 / 17 / 2007$ & $5 / 30 / 2007$ & 5 \\
\hline SW846-8260 & VOA & 1,2-Dichloropropane & $\mathrm{QC}$ & 5 & $\mathrm{ug} / \mathrm{L}$ & $\mathrm{u}$ & $5 / 15 / 2007$ & $5 / 29 / 2007$ & 5 \\
\hline SW846-8260 & VOA & 1,2-Dichloropropane & $\mathrm{QC}$ & 5 & $\mathrm{ug} / \mathrm{L}$ & $u$ & $5 / 21 / 2007$ & 6/1/2007 & 5 \\
\hline SW846-8260 & VOA & 1,2-Dichloropropane & $\mathrm{QC}$ & 5 & $\mathrm{ug} / \mathrm{L}$ & $\mathrm{U}$ & $5 / 22 / 2007$ & $6 / 5 / 2007$ & 5 \\
\hline SW846-8260 & VOA & 1,2-Dichloropropane & QC & 5 & $\mathrm{ug} / \mathrm{L}$ & $\mathrm{U}$ & $5 / 16 / 2007$ & $5 / 30 / 2007$ & 5 \\
\hline SW846-8260 & VOA & 1,2-Dichloropropane & QC & 5 & $u g / L$ & $\mathrm{U}$ & $5 / 22 / 2007$ & $6 / 5 / 2007$ & 5 \\
\hline SW846-8260 & VOA & 1,2-Dichloropropane & $\mathrm{QC}$ & 5 & $u g / L$ & $\mathrm{U}$ & $5 / 22 / 2007$ & $6 / 5 / 2007$ & 5 \\
\hline SW846-8260 & VOA & 1,2-Dichloropropane & $\mathrm{QC}$ & 5 & $\mathrm{ug} / \mathrm{L}$ & $\mathrm{u}$ & $5 / 23 / 2007$ & $6 / 5 / 2007$ & 5 \\
\hline SW846-8260 & VOA & 1,2-Dimethylbenzene & MW125 & 25 & $\mathrm{ug} / \mathrm{L}$ & $\mathrm{u}$ & $5 / 21 / 2007$ & $6 / 1 / 2007$ & 25 \\
\hline SW846-8260 & VOA & 1,2-Dimethylbenzene & MW168 & 5 & ug/L & u & $5 / 16 / 2007$ & $5 / 30 / 2007$ & 5 \\
\hline SW846-8260 & VOA & 1,2-Dimethylbenzene & MW185 & 120 & $\mathrm{ug} / \mathrm{L}$ & $\mathrm{U}$ & $5 / 23 / 2007$ & $6 / 5 / 2007$ & 120 \\
\hline SW846-8260 & VOA & 1,2-Dimethylbenzene & MW194 & 5 & $u g / L$ & $\mathrm{U}$ & $5 / 17 / 2007$ & $5 / 30 / 2007$ & 5 \\
\hline SW846-8260 & VOA & 1,2-Dimethylbenzene & MW197 & 5 & $\mathrm{ug} / \mathrm{L}$ & $u$ & $5 / 21 / 2007$ & $6 / 1 / 2007$ & 5 \\
\hline SW846-8260 & VOA & 1,2-Dimethylbenzene & MW236 & 5 & $\mathrm{ug} / \mathrm{L}$ & $\mathrm{U}$ & $5 / 22 / 2007$ & $6 / 5 / 2007$ & 5 \\
\hline SW846-8260 & VOA & 1,2-Dimethylbenzene & MW236 & 5 & $u g / L$ & $\mathrm{U}$ & $5 / 22 / 2007$ & $6 / 5 / 2007$ & 5 \\
\hline SW846-8260 & VOA & 1,2-Dimethylbenzene & MW242 & 5 & $\mathrm{ug} / \mathrm{L}$ & $\mathrm{U}$ & $5 / 17 / 2007$ & $5 / 30 / 2007$ & 5 \\
\hline SW846-8260 & VOA & 1,2-Dimethylbenzene & MW243 & 5 & $\mathrm{ug} / \mathrm{L}$ & u & $5 / 15 / 2007$ & $5 / 29 / 2007$ & 5 \\
\hline SW846-8260 & VOA & 1,2-Dimethylbenzene & MW262 & 50 & $\mathrm{ug} / \mathrm{L}$ & $\mathrm{U}$ & $5 / 16 / 2007$ & $5 / 30 / 2007$ & 50 \\
\hline SW846-8260 & VOA & 1,2-Dimethylbenzene & MW340 & 250 & $u g / L$ & $\mathrm{u}$ & $5 / 23 / 2007$ & 6/5/2007 & 250 \\
\hline SW846-8260 & VOA & 1,2-Dimethylbenzene & MW381 & 5 & $u g / L$ & u & $5 / 22 / 2007$ & $6 / 5 / 2007$ & 5 \\
\hline SW846-8260 & VOA & 1,2-Dimethylbenzene & MW66 & 100 & $\mathrm{ug} / \mathrm{L}$ & $\mathrm{u}$ & $5 / 15 / 2007$ & $5 / 29 / 2007$ & 100 \\
\hline SW846-8260 & VOA & 1,2-Dimethylbenzene & $\mathrm{QC}$ & 5 & $\mathrm{ug} / \mathrm{L}$ & $u$ & $5 / 17 / 2007$ & $5 / 30 / 2007$ & 5 \\
\hline SW846-8260 & VOA & 1,2-Dimethylbenzene & $\mathrm{QC}$ & 5 & $\mathrm{ug} / \mathrm{L}$ & $u$ & $5 / 21 / 2007$ & $6 / 1 / 2007$ & 5 \\
\hline SW846-8260 & VOA & 1,2-Dimethylbenzene & $\mathrm{QC}$ & 5 & $u g / L$ & $u$ & $5 / 22 / 2007$ & $6 / 5 / 2007$ & 5 \\
\hline SW846-8260 & VOA & 1,2-Dimethylbenzene & $\mathrm{QC}$ & 5 & $\mathrm{ug} / \mathrm{L}$ & $\mathrm{U}$ & $5 / 15 / 2007$ & $5 / 29 / 2007$ & 5 \\
\hline SW846-8260 & VOA & 1,2-Dimethylbenzene & $\mathrm{QC}$ & 5 & $u g / L$ & u & $5 / 16 / 2007$ & $5 / 30 / 2007$ & 5 \\
\hline SW846-8260 & VOA & 1,2-Dimethylbenzene & $\mathrm{QC}$ & 5 & $u g / L$ & U & $5 / 22 / 2007$ & $6 / 5 / 2007$ & 5 \\
\hline SW846-8260 & VOA & 1,2-Dimethylbenzene & $\mathrm{QC}$ & 5 & $u g / L$ & $\mathrm{U}$ & $5 / 22 / 2007$ & $6 / 5 / 2007$ & 5 \\
\hline SW846-8260 & VOA & 1,2-Dimethylbenzene & QC & 5 & $\mathrm{ug} / \mathrm{L}$ & $\mathrm{u}$ & $5 / 23 / 2007$ & $6 / 5 / 2007$ & 5 \\
\hline SW846-8260 & VOA & 2-Butanone & MW125 & 50 & $\mathrm{ug} / \mathrm{L}$ & $\mathrm{U}$ & $5 / 21 / 2007$ & $6 / 1 / 2007$ & 50 \\
\hline SW846-8260 & VOA & 2-Butanone & MW168 & 10 & $\mathrm{ug} / \mathrm{L}$ & JU & $5 / 16 / 2007$ & $5 / 30 / 2007$ & 10 \\
\hline SW846-8260 & VOA & 2-Butanone & MW185 & 250 & ug/L & $u$ & $5 / 23 / 2007$ & 6/5/2007 & 250 \\
\hline SW846-8260 & VOA & 2-Butanone & MW194 & 10 & ug/L & JU & $5 / 17 / 2007$ & $5 / 30 / 2007$ & 10 \\
\hline SW846-8260 & VOA & 2-Butanone & MW197 & 10 & ug/L & $U$ & $5 / 21 / 2007$ & $6 / 1 / 2007$ & 10 \\
\hline SW846-8260 & VOA & 2-Butanone & MW236 & 10 & $\mathrm{ug} / \mathrm{L}$ & $u$ & $5 / 22 / 2007$ & $6 / 5 / 2007$ & 10 \\
\hline SW846-8260 & VOA & 2-Butanone & MW236 & 10 & ug/L & $U$ & $5 / 22 / 2007$ & $6 / 5 / 2007$ & 10 \\
\hline SW846-8260 & VOA & 2-Butanone & MW242 & 10 & $\mathrm{ug} / \mathrm{L}$ & JU & $5 / 17 / 2007$ & $5 / 30 / 2007$ & 10 \\
\hline SW846-8260 & VOA & 2-Butanone & MW243 & 10 & ug/L & $\mathrm{U}$ & $5 / 15 / 2007$ & $5 / 29 / 2007$ & 10 \\
\hline SW846-8260 & VOA & 2-Butanone & MW262 & 100 & $\mathrm{ug} / \mathrm{L}$ & JU & $5 / 16 / 2007$ & $5 / 30 / 2007$ & 100 \\
\hline SW846-8260 & VOA & 2-Butanone & MW340 & 500 & $\mathrm{ug} / \mathrm{L}$ & $u$ & $5 / 23 / 2007$ & 6/5/2007 & 500 \\
\hline SW846-8260 & VOA & 2-Butanone & MW381 & 10 & ug/L & $U$ & $5 / 22 / 2007$ & $6 / 5 / 2007$ & 10 \\
\hline SW846-8260 & VOA & 2-Butanone & MW66 & 200 & $\mathrm{ug} / \mathrm{L}$ & $U$ & $5 / 15 / 2007$ & $5 / 29 / 2007$ & 200 \\
\hline SW846-8260 & VOA & 2-Butanone & QC & 10 & ug/L & $\mathrm{JU}$ & $5 / 17 / 2007$ & $5 / 30 / 2007$ & 10 \\
\hline SW846-8260 & VOA & 2-Butanone & $\mathrm{QC}$ & 10 & $\mathrm{ug} / \mathrm{L}$ & $u$ & $5 / 21 / 2007$ & $6 / 1 / 2007$ & 10 \\
\hline SW846-8260 & VOA & 2-Butanone & QC & 10 & ug/L & $U$ & $5 / 22 / 2007$ & $6 / 5 / 2007$ & 10 \\
\hline SW846-8260 & VOA & 2-Butanone & QC & 10 & ug/L & $U$ & $5 / 15 / 2007$ & $5 / 29 / 2007$ & 10 \\
\hline SW846-8260 & VOA & 2-Butanone & QC & 10 & $\mathrm{ug} / \mathrm{L}$ & $\mathrm{JU}$ & $5 / 16 / 2007$ & $5 / 30 / 2007$ & 10 \\
\hline
\end{tabular}




\begin{tabular}{|c|c|c|c|c|c|c|c|c|c|}
\hline Method & AnaType & Chemical Name & Station & Results & Units & $\begin{array}{c}\text { Result } \\
\text { Qualifier }\end{array}$ & Date Collected & $\begin{array}{c}\text { Date } \\
\text { Analyzed }\end{array}$ & $\begin{array}{l}\text { Detection } \\
\text { Limit }\end{array}$ \\
\hline SW846-8260 & VOA & 2-Butanone & $\mathrm{QC}$ & 10 & ug/L & U & $5 / 22 / 2007$ & $6 / 5 / 2007$ & 10 \\
\hline SW846-8260 & VOA & 2-Butanone & $\mathrm{QC}$ & 10 & $\mathrm{ug} / \mathrm{L}$ & $u$ & $5 / 22 / 2007$ & $6 / 5 / 2007$ & 10 \\
\hline SW846-8260 & VOA & 2-Butanone & QC & 10 & ug/L & U & $5 / 23 / 2007$ & $6 / 5 / 2007$ & 10 \\
\hline SW846-8260 & VOA & 2-Hexanone & MW125 & 50 & $\mathrm{ug} / \mathrm{L}$ & $u$ & $5 / 21 / 2007$ & $6 / 1 / 2007$ & 50 \\
\hline SW846-8260 & VOA & 2-Hexanone & MW168 & 10 & ug/L & U & $5 / 16 / 2007$ & $5 / 30 / 2007$ & 10 \\
\hline SW846-8260 & VOA & 2-Hexanone & MW185 & 250 & ug/L & $U$ & $5 / 23 / 2007$ & $6 / 5 / 2007$ & 250 \\
\hline SW846-8260 & VOA & 2-Hexanone & MW194 & 10 & ug/L & $U$ & $5 / 17 / 2007$ & $5 / 30 / 2007$ & 10 \\
\hline SW846-8260 & VOA & 2-Hexanone & MW197 & 10 & ug/L & U & $5 / 21 / 2007$ & $6 / 1 / 2007$ & 10 \\
\hline SW846-8260 & VOA & 2-Hexanone & MW236 & 10 & ug/L & $U$ & $5 / 22 / 2007$ & $6 / 5 / 2007$ & 10 \\
\hline SW846-8260 & VOA & 2-Hexanone & MW236 & 10 & ug/L & U & $5 / 22 / 2007$ & $6 / 5 / 2007$ & 10 \\
\hline SW846-8260 & VOA & 2-Hexanone & MW242 & 10 & $\mathrm{ug} / \mathrm{L}$ & U & $5 / 17 / 2007$ & $5 / 30 / 2007$ & 10 \\
\hline SW846-8260 & VOA & 2-Hexanone & MW243 & 10 & $\mathrm{ug} / \mathrm{L}$ & U & $5 / 15 / 2007$ & $5 / 29 / 2007$ & 10 \\
\hline SW846-8260 & VOA & 2-Hexanone & MW262 & 100 & ug/L & $U$ & $5 / 16 / 2007$ & $5 / 30 / 2007$ & 100 \\
\hline SW846-8260 & VOA & 2-Hexanone & MW340 & 500 & ug/L & $U$ & $5 / 23 / 2007$ & $6 / 5 / 2007$ & 500 \\
\hline SW846-8260 & VOA & 2-Hexanone & MW381 & 10 & ug/L & U & $5 / 22 / 2007$ & $6 / 5 / 2007$ & 10 \\
\hline SW846-8260 & VOA & 2-Hexanone & MW66 & 200 & $\mathrm{ug} / \mathrm{L}$ & $U$ & $5 / 15 / 2007$ & $5 / 29 / 2007$ & 200 \\
\hline SW846-8260 & VOA & 2-Hexanone & QC & 10 & ug/L & U & $5 / 17 / 2007$ & $5 / 30 / 2007$ & 10 \\
\hline SW846-8260 & VOA & 2-Hexanone & $\mathrm{QC}$ & 10 & ug/L & $U$ & $5 / 15 / 2007$ & $5 / 29 / 2007$ & 10 \\
\hline SW846-8260 & VOA & 2-Hexanone & QC & 10 & $\mathrm{ug} / \mathrm{L}$ & U & $5 / 21 / 2007$ & $6 / 1 / 2007$ & 10 \\
\hline SW846-8260 & VOA & 2-Hexanone & QC & 10 & ug/L & U & $5 / 22 / 2007$ & $6 / 5 / 2007$ & 10 \\
\hline SW846-8260 & VOA & 2-Hexanone & QC & 10 & $\mathrm{ug} / \mathrm{L}$ & U & $5 / 16 / 2007$ & $5 / 30 / 2007$ & 10 \\
\hline SW846-8260 & VOA & 2-Hexanone & QC & 10 & ug/L & U & $5 / 22 / 2007$ & $6 / 5 / 2007$ & 10 \\
\hline SW846-8260 & VOA & 2-Hexanone & $\mathrm{QC}$ & 10 & $\mathrm{ug} / \mathrm{L}$ & $u$ & $5 / 22 / 2007$ & $6 / 5 / 2007$ & 10 \\
\hline SW846-8260 & VOA & 2-Hexanone & QC & 10 & ug/L & U & $5 / 23 / 2007$ & $6 / 5 / 2007$ & 10 \\
\hline SW846-8260 & VOA & 4-Methyl-2-pentanone & MW125 & 50 & $\mathrm{ug} / \mathrm{L}$ & $u$ & $5 / 21 / 2007$ & $6 / 1 / 2007$ & 50 \\
\hline SW846-8260 & VOA & 4-Methyl-2-pentanone & MW168 & 10 & $\mathrm{ug} / \mathrm{L}$ & U & $5 / 16 / 2007$ & $5 / 30 / 2007$ & 10 \\
\hline SW846-8260 & VOA & 4-Methyl-2-pentanone & MW185 & 250 & $\mathrm{ug} / \mathrm{L}$ & $\mathrm{U}$ & $5 / 23 / 2007$ & $6 / 5 / 2007$ & 250 \\
\hline SW846-8260 & VOA & 4-Methyl-2-pentanone & MW194 & 10 & $\mathrm{ug} / \mathrm{L}$ & U & $5 / 17 / 2007$ & $5 / 30 / 2007$ & 10 \\
\hline SW846-8260 & VOA & 4-Methyl-2-pentanone & MW197 & 10 & $u g / L$ & $u$ & $5 / 21 / 2007$ & $6 / 1 / 2007$ & 10 \\
\hline SW846-8260 & VOA & 4-Methyl-2-pentanone & MW236 & 10 & $\mathrm{ug} / \mathrm{L}$ & $\mathrm{u}$ & $5 / 22 / 2007$ & $6 / 5 / 2007$ & 10 \\
\hline SW846-8260 & VOA & 4-Methyl-2-pentanone & MW236 & 10 & ug/L & U & $5 / 22 / 2007$ & $6 / 5 / 2007$ & 10 \\
\hline SW846-8260 & VOA & 4-Methyl-2-pentanone & MW242 & 10 & $\mathrm{ug} / \mathrm{L}$ & u & $5 / 17 / 2007$ & $5 / 30 / 2007$ & 10 \\
\hline SW846-8260 & VOA & 4-Methyl-2-pentanone & MW243 & 10 & $\mathrm{ug} / \mathrm{L}$ & $\mathrm{U}$ & $5 / 15 / 2007$ & $5 / 29 / 2007$ & 10 \\
\hline SW846-8260 & VOA & 4-Methyl-2-pentanone & MW262 & 100 & $u g / L$ & $\mathrm{u}$ & $5 / 16 / 2007$ & $5 / 30 / 2007$ & 100 \\
\hline SW846-8260 & VOA & 4-Methyl-2-pentanone & MW340 & 500 & $\mathrm{ug} / \mathrm{L}$ & $\mathrm{U}$ & $5 / 23 / 2007$ & $6 / 5 / 2007$ & 500 \\
\hline SW846-8260 & VOA & 4-Methyl-2-pentanone & MW381 & 10 & $\mathrm{ug} / \mathrm{L}$ & $u$ & $5 / 22 / 2007$ & $6 / 5 / 2007$ & 10 \\
\hline SW846-8260 & VOA & 4-Methyl-2-pentanone & MW66 & 200 & $\mathrm{ug} / \mathrm{L}$ & $\mathrm{U}$ & $5 / 15 / 2007$ & $5 / 29 / 2007$ & 200 \\
\hline SW846-8260 & VOA & 4-Methyl-2-pentanone & QC & 10 & $u g / L$ & U & $5 / 17 / 2007$ & $5 / 30 / 2007$ & 10 \\
\hline SW846-8260 & VOA & 4-Methyl-2-pentanone & QC & 10 & $\mathrm{ug} / \mathrm{L}$ & u & $5 / 21 / 2007$ & $6 / 1 / 2007$ & 10 \\
\hline SW846-8260 & VOA & 4-Methyl-2-pentanone & $\mathrm{QC}$ & 10 & $\mathrm{ug} / \mathrm{L}$ & U & $5 / 22 / 2007$ & $6 / 5 / 2007$ & 10 \\
\hline SW846-8260 & VOA & 4-Methyl-2-pentanone & $\mathrm{QC}$ & 10 & $u g / L$ & u & $5 / 15 / 2007$ & $5 / 29 / 2007$ & 10 \\
\hline SW846-8260 & VOA & 4-Methyl-2-pentanone & $\mathrm{QC}$ & 10 & $u g / L$ & u & $5 / 16 / 2007$ & $5 / 30 / 2007$ & 10 \\
\hline SW846-8260 & VOA & 4-Methyl-2-pentanone & $\mathrm{QC}$ & 10 & ug/L & $\mathrm{U}$ & $5 / 22 / 2007$ & $6 / 5 / 2007$ & 10 \\
\hline SW846-8260 & VOA & 4-Methyl-2-pentanone & $\mathrm{QC}$ & 10 & $\mathrm{ug} / \mathrm{L}$ & $u$ & $5 / 22 / 2007$ & $6 / 5 / 2007$ & 10 \\
\hline SW846-8260 & VOA & 4-Methyl-2-pentanone & QC & 10 & ug/L & U & $5 / 23 / 2007$ & $6 / 5 / 2007$ & 10 \\
\hline SW846-8260 & VOA & Acetone & MW125 & 50 & ug/L & $\mathrm{U}$ & $5 / 21 / 2007$ & $6 / 1 / 2007$ & 50 \\
\hline SW846-8260 & VOA & Acetone & MW168 & 10 & ug/L & JU & $5 / 16 / 2007$ & $5 / 30 / 2007$ & 10 \\
\hline SW846-8260 & VOA & Acetone & MW185 & 250 & $u g / L$ & JU & $5 / 23 / 2007$ & $6 / 5 / 2007$ & 250 \\
\hline SW846-8260 & VOA & Acetone & MW194 & 10 & ug/L & JU & $5 / 17 / 2007$ & $5 / 30 / 2007$ & 10 \\
\hline SW846-8260 & VOA & Acetone & MW197 & 10 & ug/L & $\mathrm{U}$ & $5 / 21 / 2007$ & 6/1/2007 & 10 \\
\hline SW846-8260 & VOA & Acetone & MW236 & 10 & $\mathrm{ug} / \mathrm{L}$ & $\mathrm{JU}$ & $5 / 22 / 2007$ & $6 / 5 / 2007$ & 10 \\
\hline SW846-8260 & VOA & Acetone & MW236 & 10 & ug/L & JU & $5 / 22 / 2007$ & $6 / 5 / 2007$ & 10 \\
\hline SW846-8260 & VOA & Acetone & MW242 & 10 & $\mathrm{ug} / \mathrm{L}$ & $\mathrm{JU}$ & $5 / 17 / 2007$ & $5 / 30 / 2007$ & 10 \\
\hline SW846-8260 & VOA & Acetone & MW243 & 10 & ug/L & $U$ & $5 / 15 / 2007$ & $5 / 29 / 2007$ & 10 \\
\hline SW846-8260 & VOA & Acetone & MW262 & 100 & ug/L & JU & $5 / 16 / 2007$ & $5 / 30 / 2007$ & 100 \\
\hline SW846-8260 & VOA & Acetone & MW340 & 500 & ug/L & JU & $5 / 23 / 2007$ & $6 / 5 / 2007$ & 500 \\
\hline SW846-8260 & VOA & Acetone & MW381 & 10 & ug/L & JU & $5 / 22 / 2007$ & 6/5/2007 & 10 \\
\hline SW846-8260 & VOA & Acetone & MW66 & 200 & ug/L & $U$ & $5 / 15 / 2007$ & $5 / 29 / 2007$ & 200 \\
\hline SW846-8260 & VOA & Acetone & QC & 10 & ug/L & JU & $5 / 17 / 2007$ & $5 / 30 / 2007$ & 10 \\
\hline SW846-8260 & VOA & Acetone & QC & 10 & ug/L & $\mathrm{U}$ & $5 / 21 / 2007$ & $6 / 1 / 2007$ & 10 \\
\hline SW846-8260 & VOA & Acetone & QC & 10 & $\mathrm{ug} / \mathrm{L}$ & $\mathrm{JU}$ & $5 / 22 / 2007$ & $6 / 5 / 2007$ & 10 \\
\hline SW846-8260 & VOA & Acetone & $\mathrm{QC}$ & 10 & $\mathrm{ug} / \mathrm{L}$ & $u$ & $5 / 15 / 2007$ & $5 / 29 / 2007$ & 10 \\
\hline SW846-8260 & VOA & Acetone & $\mathrm{QC}$ & 10 & ug/L & JU & $5 / 16 / 2007$ & $5 / 30 / 2007$ & 10 \\
\hline SW846-8260 & VOA & Acetone & $\mathrm{QC}$ & 54 & ug/L & $\mathrm{J}$ & $5 / 22 / 2007$ & $6 / 5 / 2007$ & 10 \\
\hline SW846-8260 & VOA & Acetone & $\mathrm{QC}$ & 14 & ug/L & $\mathrm{J}$ & $5 / 22 / 2007$ & $6 / 5 / 2007$ & 10 \\
\hline SW846-8260 & VOA & Acetone & QC & 10 & ug/L & $\mathrm{JU}$ & $5 / 23 / 2007$ & $6 / 5 / 2007$ & 10 \\
\hline SW846-8260 & VOA & Benzene & MW125 & 25 & $\mathrm{ug} / \mathrm{L}$ & $u$ & $5 / 21 / 2007$ & $6 / 1 / 2007$ & 25 \\
\hline SW846-8260 & VOA & Benzene & MW168 & 5 & ug/L & U & $5 / 16 / 2007$ & $5 / 30 / 2007$ & 5 \\
\hline SW846-8260 & VOA & Benzene & MW185 & 120 & ug/L & $U$ & $5 / 23 / 2007$ & $6 / 5 / 2007$ & 120 \\
\hline
\end{tabular}




\begin{tabular}{|c|c|c|c|c|c|c|c|c|c|}
\hline Method & AnaType & Chemical Name & Station & Results & Units & $\begin{array}{l}\text { Result } \\
\text { Qualifier }\end{array}$ & Date Collected & $\begin{array}{c}\text { Date } \\
\text { Analyzed }\end{array}$ & $\begin{array}{l}\text { Detection } \\
\text { Limit }\end{array}$ \\
\hline SW846-8260 & VOA & Benzene & MW194 & 5 & ug/L & U & $5 / 17 / 2007$ & $5 / 30 / 2007$ & 5 \\
\hline SW846-8260 & VOA & Benzene & MW197 & 5 & ug/L & $U$ & $5 / 21 / 2007$ & $6 / 1 / 2007$ & 5 \\
\hline SW846-8260 & VOA & Benzene & MW236 & 5 & ug/L & $U$ & $5 / 22 / 2007$ & $6 / 5 / 2007$ & 5 \\
\hline SW846-8260 & VOA & Benzene & MW236 & 5 & ug/L & $\mathrm{U}$ & $5 / 22 / 2007$ & $6 / 5 / 2007$ & 5 \\
\hline SW846-8260 & VOA & Benzene & MW242 & 5 & ug/L & $\mathrm{U}$ & $5 / 17 / 2007$ & $5 / 30 / 2007$ & 5 \\
\hline SW846-8260 & VOA & Benzene & MW243 & 5 & ug/L & $\mathrm{U}$ & $5 / 15 / 2007$ & $5 / 29 / 2007$ & 5 \\
\hline SW846-8260 & VOA & Benzene & MW262 & 50 & ug/L & $\mathrm{U}$ & $5 / 16 / 2007$ & $5 / 30 / 2007$ & 50 \\
\hline SW846-8260 & VOA & Benzene & MW340 & 250 & ug/L & $\cup$ & $5 / 23 / 2007$ & $6 / 5 / 2007$ & 250 \\
\hline SW846-8260 & VOA & Benzene & MW381 & 5 & ug/L & $\cup$ & $5 / 22 / 2007$ & $6 / 5 / 2007$ & 5 \\
\hline SW846-8260 & VOA & Benzene & MW66 & 100 & ug/L & $\mathrm{U}$ & $5 / 15 / 2007$ & $5 / 29 / 2007$ & 100 \\
\hline SW846-8260 & VOA & Benzene & QC & 5 & ug/L & $\mathrm{U}$ & $5 / 16 / 2007$ & $5 / 30 / 2007$ & 5 \\
\hline SW846-8260 & VOA & Benzene & QC & 5 & $\mathrm{ug} / \mathrm{L}$ & $\mathrm{U}$ & $5 / 17 / 2007$ & $5 / 30 / 2007$ & 5 \\
\hline SW846-8260 & VOA & Benzene & QC & 5 & ug/L & $U$ & $5 / 21 / 2007$ & $6 / 1 / 2007$ & 5 \\
\hline SW846-8260 & VOA & Benzene & QC & 5 & ug/L & $\mathrm{U}$ & $5 / 15 / 2007$ & $5 / 29 / 2007$ & 5 \\
\hline SW846-8260 & VOA & Benzene & QC & 5 & ug/L & $U$ & $5 / 22 / 2007$ & $6 / 5 / 2007$ & 5 \\
\hline SW846-8260 & VOA & Benzene & QC & 5 & ug/L & $\mathrm{U}$ & $5 / 22 / 2007$ & $6 / 5 / 2007$ & 5 \\
\hline SW846-8260 & VOA & Benzene & QC & 5 & ug/L & $\mathrm{U}$ & $5 / 22 / 2007$ & $6 / 5 / 2007$ & 5 \\
\hline SW846-8260 & VOA & Benzene & QC & 5 & ug/L & $\mathrm{U}$ & $5 / 23 / 2007$ & $6 / 5 / 2007$ & 5 \\
\hline SW846-8260 & VOA & Bromodichloromethane & MW125 & 25 & $\mathrm{ug} / \mathrm{L}$ & $\mathrm{U}$ & $5 / 21 / 2007$ & $6 / 1 / 2007$ & 25 \\
\hline SW846-8260 & VOA & Bromodichloromethane & MW168 & 5 & ug/L & $\mathrm{U}$ & $5 / 16 / 2007$ & $5 / 30 / 2007$ & 5 \\
\hline SW846-8260 & VOA & Bromodichloromethane & MW185 & 120 & ug/L & $\mathrm{U}$ & $5 / 23 / 2007$ & $6 / 5 / 2007$ & 120 \\
\hline SW846-8260 & VOA & Bromodichloromethane & MW194 & 5 & ug/L & $\mathrm{U}$ & $5 / 17 / 2007$ & $5 / 30 / 2007$ & 5 \\
\hline SW846-8260 & VOA & Bromodichloromethane & MW197 & 5 & ug/L & $\mathrm{U}$ & $5 / 21 / 2007$ & $6 / 1 / 2007$ & 5 \\
\hline SW846-8260 & VOA & Bromodichloromethane & MW236 & 5 & ug/L & $U$ & $5 / 22 / 2007$ & $6 / 5 / 2007$ & 5 \\
\hline SW846-8260 & VOA & Bromodichloromethane & MW236 & 5 & ug/L & $U$ & $5 / 22 / 2007$ & $6 / 5 / 2007$ & 5 \\
\hline SW846-8260 & VOA & Bromodichloromethane & MW242 & 5 & ug/L & $U$ & $5 / 17 / 2007$ & $5 / 30 / 2007$ & 5 \\
\hline SW846-8260 & VOA & Bromodichloromethane & MW243 & 5 & ug/L & $U$ & $5 / 15 / 2007$ & $5 / 29 / 2007$ & 5 \\
\hline SW846-8260 & VOA & Bromodichloromethane & MW262 & 50 & ug/L & $\mathrm{U}$ & $5 / 16 / 2007$ & $5 / 30 / 2007$ & 50 \\
\hline SW846-8260 & VOA & Bromodichloromethane & MW340 & 250 & $\mathrm{ug} / \mathrm{L}$ & $\mathrm{U}$ & $5 / 23 / 2007$ & $6 / 5 / 2007$ & 250 \\
\hline SW846-8260 & VOA & Bromodichloromethane & MW381 & 5 & $\mathrm{ug} / \mathrm{L}$ & $\mathrm{U}$ & $5 / 22 / 2007$ & $6 / 5 / 2007$ & 5 \\
\hline SW846-8260 & VOA & Bromodichloromethane & MW66 & 100 & ug/L & $\mathrm{U}$ & $5 / 15 / 2007$ & $5 / 29 / 2007$ & 100 \\
\hline SW846-8260 & VOA & Bromodichloromethane & $\mathrm{QC}$ & 5 & ug/L & $U$ & $5 / 16 / 2007$ & $5 / 30 / 2007$ & 5 \\
\hline SW846-8260 & VOA & Bromodichloromethane & QC & 5 & ug/L & $\mathrm{U}$ & $5 / 17 / 2007$ & $5 / 30 / 2007$ & 5 \\
\hline SW846-8260 & VOA & Bromodichloromethane & $\mathrm{QC}$ & 5 & ug/L & $U$ & $5 / 21 / 2007$ & $6 / 1 / 2007$ & 5 \\
\hline SW846-8260 & VOA & Bromodichloromethane & QC & 5 & ug/L & $\mathrm{U}$ & $5 / 22 / 2007$ & $6 / 5 / 2007$ & 5 \\
\hline SW846-8260 & VOA & Bromodichloromethane & QC & 5 & ug/L & $\mathrm{U}$ & $5 / 15 / 2007$ & $5 / 29 / 2007$ & 5 \\
\hline SW846-8260 & VOA & Bromodichloromethane & QC & 5 & ug/L & $U$ & $5 / 22 / 2007$ & $6 / 5 / 2007$ & 5 \\
\hline SW846-8260 & VOA & Bromodichloromethane & QC & 5 & ug/L & $\mathrm{U}$ & $5 / 22 / 2007$ & $6 / 5 / 2007$ & 5 \\
\hline SW846-8260 & VOA & Bromodichloromethane & QC & 5 & ug/L & $\mathrm{U}$ & $5 / 23 / 2007$ & $6 / 5 / 2007$ & 5 \\
\hline SW846-8260 & VOA & Bromoform & MW125 & 25 & $\mathrm{ug} / \mathrm{L}$ & $\mathrm{U}$ & $5 / 21 / 2007$ & $6 / 1 / 2007$ & 25 \\
\hline SW846-8260 & VOA & Bromoform & MW168 & 5 & ug/L & $\mathrm{U}$ & $5 / 16 / 2007$ & $5 / 30 / 2007$ & 5 \\
\hline SW846-8260 & VOA & Bromoform & MW185 & 120 & ug/L & $\mathrm{U}$ & $5 / 23 / 2007$ & $6 / 5 / 2007$ & 120 \\
\hline SW846-8260 & VOA & Bromoform & MW194 & 5 & $\mathrm{ug} / \mathrm{L}$ & $\mathrm{U}$ & $5 / 17 / 2007$ & $5 / 30 / 2007$ & 5 \\
\hline SW846-8260 & VOA & Bromoform & MW197 & 5 & ug/L & $U$ & $5 / 21 / 2007$ & $6 / 1 / 2007$ & 5 \\
\hline SW846-8260 & VOA & Bromoform & MW236 & 5 & ug/L & $\mathrm{U}$ & $5 / 22 / 2007$ & $6 / 5 / 2007$ & 5 \\
\hline SW846-8260 & VOA & Bromoform & MW236 & 5 & ug/L & $U$ & $5 / 22 / 2007$ & $6 / 5 / 2007$ & 5 \\
\hline SW846-8260 & VOA & Bromoform & MW242 & 5 & ug/L & $\mathrm{U}$ & $5 / 17 / 2007$ & $5 / 30 / 2007$ & 5 \\
\hline SW846-8260 & VOA & Bromoform & MW243 & 5 & ug/L & $\mathrm{U}$ & $5 / 15 / 2007$ & $5 / 29 / 2007$ & 5 \\
\hline SW846-8260 & VOA & Bromoform & MW262 & 50 & ug/L & $\mathrm{U}$ & $5 / 16 / 2007$ & $5 / 30 / 2007$ & 50 \\
\hline SW846-8260 & VOA & Bromoform & MW340 & 250 & ug/L & $\mathrm{U}$ & $5 / 23 / 2007$ & $6 / 5 / 2007$ & 250 \\
\hline SW846-8260 & VOA & Bromoform & MW381 & 5 & ug/L & $U$ & $5 / 22 / 2007$ & $6 / 5 / 2007$ & 5 \\
\hline SW846-8260 & VOA & Bromoform & MW66 & 100 & ug/L & $\mathrm{U}$ & $5 / 15 / 2007$ & $5 / 29 / 2007$ & 100 \\
\hline SW846-8260 & VOA & Bromoform & QC & 5 & $\mathrm{ug} / \mathrm{L}$ & $\mathrm{U}$ & $5 / 16 / 2007$ & $5 / 30 / 2007$ & 5 \\
\hline SW846-8260 & VOA & Bromoform & $\mathrm{QC}$ & 5 & ug/L & $\mathrm{U}$ & $5 / 17 / 2007$ & $5 / 30 / 2007$ & 5 \\
\hline SW846-8260 & VOA & Bromoform & QC & 5 & ug/L & $\mathrm{U}$ & $5 / 21 / 2007$ & 6/1/2007 & 5 \\
\hline SW846-8260 & VOA & Bromoform & $\mathrm{QC}$ & 5 & ug/L & $U$ & $5 / 15 / 2007$ & $5 / 29 / 2007$ & 5 \\
\hline SW846-8260 & VOA & Bromoform & QC & 5 & ug/L & $\cup$ & $5 / 22 / 2007$ & $6 / 5 / 2007$ & 5 \\
\hline SW846-8260 & VOA & Bromoform & $\mathrm{QC}$ & 5 & ug/L & $U$ & $5 / 22 / 2007$ & $6 / 5 / 2007$ & 5 \\
\hline SW846-8260 & VOA & Bromoform & QC & 5 & ug/L & $\mathrm{U}$ & $5 / 22 / 2007$ & $6 / 5 / 2007$ & 5 \\
\hline SW846-8260 & VOA & Bromoform & QC & 5 & ug/L & $\mathrm{U}$ & $5 / 23 / 2007$ & $6 / 5 / 2007$ & 5 \\
\hline SW846-8260 & VOA & Bromomethane & MW125 & 25 & ug/L & $U$ & $5 / 21 / 2007$ & 6/1/2007 & 25 \\
\hline SW846-8260 & VOA & Bromomethane & MW168 & 5 & ug/L & $U$ & $5 / 16 / 2007$ & $5 / 30 / 2007$ & 5 \\
\hline SW846-8260 & VOA & Bromomethane & MW185 & 120 & ug/L & $U$ & $5 / 23 / 2007$ & $6 / 5 / 2007$ & 120 \\
\hline SW846-8260 & VOA & Bromomethane & MW194 & 5 & ug/L & $\mathrm{U}$ & $5 / 17 / 2007$ & $5 / 30 / 2007$ & 5 \\
\hline SW846-8260 & VOA & Bromomethane & MW197 & 5 & ug/L & $\mathrm{U}$ & $5 / 21 / 2007$ & $6 / 1 / 2007$ & 5 \\
\hline SW846-8260 & VOA & Bromomethane & MW236 & 5 & ug/L & $\mathrm{U}$ & $5 / 22 / 2007$ & $6 / 5 / 2007$ & 5 \\
\hline SW846-8260 & VOA & Bromomethane & MW236 & 5 & ug/L & $\mathrm{U}$ & $5 / 22 / 2007$ & $6 / 5 / 2007$ & 5 \\
\hline SW846-8260 & VOA & Bromomethane & MW242 & 5 & ug/L & $\mathrm{U}$ & $5 / 17 / 2007$ & $5 / 30 / 2007$ & 5 \\
\hline SW846-8260 & VOA & Bromomethane & MW243 & 5 & ug/L & $\mathrm{U}$ & $5 / 15 / 2007$ & $5 / 29 / 2007$ & 5 \\
\hline
\end{tabular}




\begin{tabular}{|c|c|c|c|c|c|c|c|c|c|}
\hline Method & AnaType & Chemical Name & Station & Results & Units & $\begin{array}{c}\text { Result } \\
\text { Qualifier }\end{array}$ & Date Collected & $\begin{array}{c}\text { Date } \\
\text { Analyzed }\end{array}$ & $\begin{array}{l}\text { Detection } \\
\text { Limit }\end{array}$ \\
\hline SW846-8260 & VOA & Bromomethane & MW262 & 50 & $u g / L$ & U & $5 / 16 / 2007$ & $5 / 30 / 2007$ & 50 \\
\hline SW846-8260 & VOA & Bromomethane & MW340 & 250 & $\mathrm{ug} / \mathrm{L}$ & $u$ & $5 / 23 / 2007$ & 6/5/2007 & 250 \\
\hline SW846-8260 & VOA & Bromomethane & MW381 & 5 & $\mathrm{ug} / \mathrm{L}$ & u & $5 / 22 / 2007$ & $6 / 5 / 2007$ & 5 \\
\hline SW846-8260 & VOA & Bromomethane & MW66 & 100 & $\mathrm{ug} / \mathrm{L}$ & $u$ & $5 / 15 / 2007$ & $5 / 29 / 2007$ & 100 \\
\hline SW846-8260 & VOA & Bromomethane & QC & 5 & $\mathrm{ug} / \mathrm{L}$ & u & $5 / 17 / 2007$ & $5 / 30 / 2007$ & 5 \\
\hline SW846-8260 & VOA & Bromomethane & QC & 5 & $\mathrm{ug} / \mathrm{L}$ & $\mathrm{U}$ & $5 / 21 / 2007$ & 6/1/2007 & 5 \\
\hline SW846-8260 & VOA & Bromomethane & QC & 5 & $\mathrm{ug} / \mathrm{L}$ & $\mathrm{U}$ & $5 / 22 / 2007$ & $6 / 5 / 2007$ & 5 \\
\hline SW846-8260 & VOA & Bromomethane & $\mathrm{QC}$ & 5 & $\mathrm{ug} / \mathrm{L}$ & $\mathrm{U}$ & $5 / 15 / 2007$ & $5 / 29 / 2007$ & 5 \\
\hline SW846-8260 & VOA & Bromomethane & $\mathrm{QC}$ & 5 & $\mathrm{ug} / \mathrm{L}$ & $\mathrm{u}$ & $5 / 16 / 2007$ & $5 / 30 / 2007$ & 5 \\
\hline SW846-8260 & VOA & Bromomethane & $\mathrm{QC}$ & 5 & $\mathrm{ug} / \mathrm{L}$ & $\mathrm{u}$ & $5 / 22 / 2007$ & $6 / 5 / 2007$ & 5 \\
\hline SW846-8260 & VOA & Bromomethane & $\mathrm{QC}$ & 5 & $\mathrm{ug} / \mathrm{L}$ & $\mathrm{U}$ & $5 / 22 / 2007$ & $6 / 5 / 2007$ & 5 \\
\hline SW846-8260 & VOA & Bromomethane & $\mathrm{QC}$ & 5 & $\mathrm{ug} / \mathrm{L}$ & $u$ & $5 / 23 / 2007$ & $6 / 5 / 2007$ & 5 \\
\hline SW846-8260 & VOA & Carbon disulfide & MW125 & 25 & $\mathrm{ug} / \mathrm{L}$ & $u$ & $5 / 21 / 2007$ & $6 / 1 / 2007$ & 25 \\
\hline SW846-8260 & VOA & Carbon disulfide & MW168 & 5 & $\mathrm{ug} / \mathrm{L}$ & $\mathrm{U}$ & $5 / 16 / 2007$ & $5 / 30 / 2007$ & 5 \\
\hline SW846-8260 & VOA & Carbon disulfide & MW185 & 120 & $\mathrm{ug} / \mathrm{L}$ & $\mathrm{u}$ & $5 / 23 / 2007$ & $6 / 5 / 2007$ & 120 \\
\hline SW846-8260 & VOA & Carbon disulfide & MW194 & 5 & $\mathrm{ug} / \mathrm{L}$ & $\mathrm{U}$ & $5 / 17 / 2007$ & $5 / 30 / 2007$ & 5 \\
\hline SW846-8260 & VOA & Carbon disulfide & MW197 & 5 & $\mathrm{ug} / \mathrm{L}$ & $\mathrm{U}$ & $5 / 21 / 2007$ & $6 / 1 / 2007$ & 5 \\
\hline SW846-8260 & VOA & Carbon disulfide & MW236 & 5 & $\mathrm{ug} / \mathrm{L}$ & $\mathrm{U}$ & $5 / 22 / 2007$ & $6 / 5 / 2007$ & 5 \\
\hline sW846-8260 & VOA & Carbon disulfide & MW236 & 5 & $\mathrm{ug} / \mathrm{L}$ & $u$ & $5 / 22 / 2007$ & $6 / 5 / 2007$ & 5 \\
\hline SW846-8260 & VOA & Carbon disulfide & MW242 & 5 & $\mathrm{ug} / \mathrm{L}$ & $u$ & $5 / 17 / 2007$ & $5 / 30 / 2007$ & 5 \\
\hline SW846-8260 & VOA & Carbon disulfide & MW243 & 5 & $\mathrm{ug} / \mathrm{L}$ & $u$ & $5 / 15 / 2007$ & $5 / 29 / 2007$ & 5 \\
\hline SW846-8260 & VOA & Carbon disulfide & MW262 & 50 & $\mathrm{ug} / \mathrm{L}$ & $\mathrm{u}$ & $5 / 16 / 2007$ & $5 / 30 / 2007$ & 50 \\
\hline SW846-8260 & VOA & Carbon disulfide & MW340 & 250 & $\mathrm{ug} / \mathrm{L}$ & $u$ & $5 / 23 / 2007$ & 6/5/2007 & 250 \\
\hline SW846-8260 & VOA & Carbon disulfide & MW381 & 5 & $\mathrm{ug} / \mathrm{L}$ & u & $5 / 22 / 2007$ & $6 / 5 / 2007$ & 5 \\
\hline SW846-8260 & VOA & Carbon disulfide & MW66 & 100 & $\mathrm{ug} / \mathrm{L}$ & $u$ & $5 / 15 / 2007$ & $5 / 29 / 2007$ & 100 \\
\hline sW846-8260 & VOA & Carbon disulfide & $\mathrm{QC}$ & 5 & $\mathrm{ug} / \mathrm{L}$ & $u$ & $5 / 16 / 2007$ & $5 / 30 / 2007$ & 5 \\
\hline SW846-8260 & VOA & Carbon disulfide & $\mathrm{QC}$ & 5 & $\mathrm{ug} / \mathrm{L}$ & $\mathrm{U}$ & $5 / 17 / 2007$ & $5 / 30 / 2007$ & 5 \\
\hline SW846-8260 & VOA & Carbon disulfide & $\mathrm{QC}$ & 5 & $\mathrm{ug} / \mathrm{L}$ & $\mathrm{U}$ & $5 / 21 / 2007$ & 6/1/2007 & 5 \\
\hline SW846-8260 & VOA & Carbon disulfide & $\mathrm{QC}$ & 5 & $\mathrm{ug} / \mathrm{L}$ & $\mathrm{U}$ & $5 / 22 / 2007$ & $6 / 5 / 2007$ & 5 \\
\hline SW846-8260 & VOA & Carbon disulfide & $\mathrm{QC}$ & 5 & $\mathrm{ug} / \mathrm{L}$ & $\mathrm{U}$ & $5 / 15 / 2007$ & $5 / 29 / 2007$ & 5 \\
\hline SW846-8260 & VOA & Carbon disulfide & $\mathrm{QC}$ & 5 & $\mathrm{ug} / \mathrm{L}$ & $U$ & $5 / 22 / 2007$ & $6 / 5 / 2007$ & 5 \\
\hline SW846-8260 & VOA & Carbon disulfide & $\mathrm{QC}$ & 5 & $\mathrm{ug} / \mathrm{L}$ & $\mathrm{U}$ & $5 / 22 / 2007$ & $6 / 5 / 2007$ & 5 \\
\hline SW846-8260 & VOA & Carbon disulfide & $\mathrm{QC}$ & 5 & $\mathrm{ug} / \mathrm{L}$ & U & $5 / 23 / 2007$ & $6 / 5 / 2007$ & 5 \\
\hline SW846-8260 & VOA & Carbon tetrachloride & MW125 & 25 & $\mathrm{ug} / \mathrm{L}$ & $\mathrm{u}$ & $5 / 21 / 2007$ & $6 / 1 / 2007$ & 25 \\
\hline SW846-8260 & VOA & Carbon tetrachloride & MW168 & 5 & $\mathrm{ug} / \mathrm{L}$ & $\mathrm{u}$ & $5 / 16 / 2007$ & $5 / 30 / 2007$ & 5 \\
\hline SW846-8260 & VOA & Carbon tetrachloride & MW185 & 120 & $\mathrm{ug} / \mathrm{L}$ & $\mathrm{u}$ & $5 / 23 / 2007$ & $6 / 5 / 2007$ & 120 \\
\hline SW846-8260 & VOA & Carbon tetrachloride & MW194 & 5 & $\mathrm{ug} / \mathrm{L}$ & $\mathrm{U}$ & $5 / 17 / 2007$ & $5 / 30 / 2007$ & 5 \\
\hline SW846-8260 & VOA & Carbon tetrachloride & MW197 & 5 & $\mathrm{ug} / \mathrm{L}$ & $u$ & $5 / 21 / 2007$ & $6 / 1 / 2007$ & 5 \\
\hline SW846-8260 & VOA & Carbon tetrachloride & MW236 & 5 & $\mathrm{ug} / \mathrm{L}$ & $\mathrm{u}$ & $5 / 22 / 2007$ & $6 / 5 / 2007$ & 5 \\
\hline SW846-8260 & VOA & Carbon tetrachloride & MW236 & 5 & $\mathrm{ug} / \mathrm{L}$ & $u$ & $5 / 22 / 2007$ & $6 / 5 / 2007$ & 5 \\
\hline SW846-8260 & VOA & Carbon tetrachloride & MW242 & 5 & $\mathrm{ug} / \mathrm{L}$ & $\mathrm{u}$ & $5 / 17 / 2007$ & $5 / 30 / 2007$ & 5 \\
\hline SW846-8260 & VOA & Carbon tetrachloride & MW243 & 5 & $\mathrm{ug} / \mathrm{L}$ & $\mathrm{U}$ & $5 / 15 / 2007$ & $5 / 29 / 2007$ & 5 \\
\hline SW846-8260 & VOA & Carbon tetrachloride & MW262 & 50 & $\mathrm{ug} / \mathrm{L}$ & $\mathrm{u}$ & $5 / 16 / 2007$ & $5 / 30 / 2007$ & 50 \\
\hline SW846-8260 & VOA & Carbon tetrachloride & MW340 & 250 & $\mathrm{ug} / \mathrm{L}$ & $\mathrm{U}$ & $5 / 23 / 2007$ & 6/5/2007 & 250 \\
\hline SW846-8260 & VOA & Carbon tetrachloride & MW381 & 5 & $\mathrm{ug} / \mathrm{L}$ & $U$ & $5 / 22 / 2007$ & $6 / 5 / 2007$ & 5 \\
\hline SW846-8260 & VOA & Carbon tetrachloride & MW66 & 100 & $\mathrm{ug} / \mathrm{L}$ & $\mathrm{u}$ & $5 / 15 / 2007$ & $5 / 29 / 2007$ & 100 \\
\hline sW846-8260 & VOA & Carbon tetrachloride & $\mathrm{QC}$ & 5 & $\mathrm{ug} / \mathrm{L}$ & U & $5 / 17 / 2007$ & $5 / 30 / 2007$ & 5 \\
\hline SW846-8260 & VOA & Carbon tetrachloride & $\mathrm{QC}$ & 5 & $\mathrm{ug} / \mathrm{L}$ & $\mathrm{u}$ & $5 / 21 / 2007$ & 6/1/2007 & 5 \\
\hline SW846-8260 & VOA & Carbon tetrachloride & $\mathrm{QC}$ & 5 & $\mathrm{ug} / \mathrm{L}$ & $\mathrm{U}$ & $5 / 22 / 2007$ & $6 / 5 / 2007$ & 5 \\
\hline SW846-8260 & VOA & Carbon tetrachloride & $\mathrm{QC}$ & 5 & $\mathrm{ug} / \mathrm{L}$ & $u$ & $5 / 15 / 2007$ & $5 / 29 / 2007$ & 5 \\
\hline SW846-8260 & VOA & Carbon tetrachloride & $\mathrm{QC}$ & 5 & $\mathrm{ug} / \mathrm{L}$ & $u$ & $5 / 16 / 2007$ & $5 / 30 / 2007$ & 5 \\
\hline SW846-8260 & VOA & Carbon tetrachloride & $\mathrm{QC}$ & 5 & $\mathrm{ug} / \mathrm{L}$ & $\mathrm{u}$ & $5 / 22 / 2007$ & $6 / 5 / 2007$ & 5 \\
\hline SW846-8260 & VOA & Carbon tetrachloride & $\mathrm{QC}$ & 5 & $\mathrm{ug} / \mathrm{L}$ & $u$ & $5 / 22 / 2007$ & $6 / 5 / 2007$ & 5 \\
\hline sw846-8260 & VOA & Carbon tetrachloride & $\mathrm{QC}$ & 5 & $\mathrm{ug} / \mathrm{L}$ & $\mathrm{U}$ & $5 / 23 / 2007$ & $6 / 5 / 2007$ & 5 \\
\hline SW846-8260 & VOA & Chlorobenzene & MW125 & 25 & $\mathrm{ug} / \mathrm{L}$ & $\mathrm{U}$ & $5 / 21 / 2007$ & $6 / 1 / 2007$ & 25 \\
\hline SW846-8260 & VOA & Chlorobenzene & MW168 & 5 & $\mathrm{ug} / \mathrm{L}$ & $u$ & $5 / 16 / 2007$ & $5 / 30 / 2007$ & 5 \\
\hline SW846-8260 & VOA & Chlorobenzene & MW185 & 120 & $\mathrm{ug} / \mathrm{L}$ & $\mathrm{u}$ & $5 / 23 / 2007$ & $6 / 5 / 2007$ & 120 \\
\hline SW846-8260 & VOA & Chlorobenzene & MW194 & 5 & $\mathrm{ug} / \mathrm{L}$ & $\mathrm{U}$ & $5 / 17 / 2007$ & $5 / 30 / 2007$ & 5 \\
\hline SW846-8260 & VOA & Chlorobenzene & MW197 & 5 & $\mathrm{ug} / \mathrm{L}$ & $U$ & $5 / 21 / 2007$ & $6 / 1 / 2007$ & 5 \\
\hline SW846-8260 & VOA & Chlorobenzene & MW236 & 5 & $\mathrm{ug} / \mathrm{L}$ & $\mathrm{U}$ & $5 / 22 / 2007$ & $6 / 5 / 2007$ & 5 \\
\hline SW846-8260 & VOA & Chlorobenzene & MW236 & 5 & $\mathrm{ug} / \mathrm{L}$ & U & $5 / 22 / 2007$ & $6 / 5 / 2007$ & 5 \\
\hline SW846-8260 & VOA & Chlorobenzene & MW242 & 5 & $\mathrm{ug} / \mathrm{L}$ & $\mathrm{U}$ & $5 / 17 / 2007$ & $5 / 30 / 2007$ & 5 \\
\hline SW846-8260 & VOA & Chlorobenzene & MW243 & 5 & $\mathrm{ug} / \mathrm{L}$ & $u$ & $5 / 15 / 2007$ & $5 / 29 / 2007$ & 5 \\
\hline SW846-8260 & VOA & Chlorobenzene & MW262 & 50 & $\mathrm{ug} / \mathrm{L}$ & $u$ & $5 / 16 / 2007$ & $5 / 30 / 2007$ & 50 \\
\hline SW846-8260 & VOA & Chlorobenzene & MW340 & 250 & $\mathrm{ug} / \mathrm{L}$ & $u$ & $5 / 23 / 2007$ & $6 / 5 / 2007$ & 250 \\
\hline SW846-8260 & VOA & Chlorobenzene & MW381 & 5 & $\mathrm{ug} / \mathrm{L}$ & $u$ & $5 / 22 / 2007$ & $6 / 5 / 2007$ & 5 \\
\hline SW846-8260 & VOA & Chlorobenzene & MW66 & 100 & ug/L & $u$ & $5 / 15 / 2007$ & $5 / 29 / 2007$ & 100 \\
\hline sW846-8260 & VOA & Chlorobenzene & $\mathrm{QC}$ & 5 & $\mathrm{ug} / \mathrm{L}$ & $u$ & $5 / 17 / 2007$ & $5 / 30 / 2007$ & 5 \\
\hline SW846-8260 & VOA & Chlorobenzene & $\mathrm{QC}$ & 5 & $\mathrm{ug} / \mathrm{L}$ & $\mathrm{U}$ & $5 / 21 / 2007$ & 6/1/2007 & 5 \\
\hline
\end{tabular}




\begin{tabular}{|c|c|c|c|c|c|c|c|c|c|}
\hline Method & AnaType & Chemical Name & Station & Results & Units & $\begin{array}{c}\text { Result } \\
\text { Qualifier }\end{array}$ & Date Collected & $\begin{array}{c}\text { Date } \\
\text { Analyzed }\end{array}$ & $\begin{array}{l}\text { Detection } \\
\text { Limit }\end{array}$ \\
\hline SW846-8260 & VOA & Chlorobenzene & QC & 5 & ug/L & $U$ & $5 / 22 / 2007$ & $6 / 5 / 2007$ & 5 \\
\hline SW846-8260 & VOA & Chlorobenzene & QC & 5 & ug/L & $U$ & $5 / 15 / 2007$ & $5 / 29 / 2007$ & 5 \\
\hline SW846-8260 & VOA & Chlorobenzene & QC & 5 & ug/L & $U$ & $5 / 16 / 2007$ & $5 / 30 / 2007$ & 5 \\
\hline SW846-8260 & VOA & Chlorobenzene & QC & 5 & $\mathrm{ug} / \mathrm{L}$ & $U$ & $5 / 22 / 2007$ & $6 / 5 / 2007$ & 5 \\
\hline SW846-8260 & VOA & Chlorobenzene & QC & 5 & ug/L & $U$ & $5 / 22 / 2007$ & $6 / 5 / 2007$ & 5 \\
\hline SW846-8260 & VOA & Chlorobenzene & QC & 5 & $\mathrm{ug} / \mathrm{L}$ & $\mathrm{U}$ & $5 / 23 / 2007$ & $6 / 5 / 2007$ & 5 \\
\hline SW846-8260 & VOA & Chloroethane & MW125 & 25 & ug/L & $\mathrm{U}$ & $5 / 21 / 2007$ & $6 / 1 / 2007$ & 25 \\
\hline SW846-8260 & VOA & Chloroethane & MW168 & 5 & $\mathrm{ug} / \mathrm{L}$ & $U$ & $5 / 16 / 2007$ & $5 / 30 / 2007$ & 5 \\
\hline SW846-8260 & VOA & Chloroethane & MW185 & 120 & ug/L & $U$ & $5 / 23 / 2007$ & $6 / 5 / 2007$ & 120 \\
\hline SW846-8260 & VOA & Chloroethane & MW194 & 5 & ug/L & $\mathrm{U}$ & $5 / 17 / 2007$ & $5 / 30 / 2007$ & 5 \\
\hline SW846-8260 & VOA & Chloroethane & MW197 & 5 & ug/L & $\mathrm{U}$ & $5 / 21 / 2007$ & $6 / 1 / 2007$ & 5 \\
\hline SW846-8260 & VOA & Chloroethane & MW236 & 5 & ug/L & $U$ & $5 / 22 / 2007$ & $6 / 5 / 2007$ & 5 \\
\hline SW846-8260 & VOA & Chloroethane & MW236 & 5 & ug/L & $U$ & $5 / 22 / 2007$ & $6 / 5 / 2007$ & 5 \\
\hline SW846-8260 & VOA & Chloroethane & MW242 & 5 & ug/L & $U$ & $5 / 17 / 2007$ & $5 / 30 / 2007$ & 5 \\
\hline SW846-8260 & VOA & Chloroethane & MW243 & 5 & ug/L & $U$ & $5 / 15 / 2007$ & $5 / 29 / 2007$ & 5 \\
\hline SW846-8260 & VOA & Chloroethane & MW262 & 50 & $\mathrm{ug} / \mathrm{L}$ & $\mathrm{U}$ & $5 / 16 / 2007$ & $5 / 30 / 2007$ & 50 \\
\hline SW846-8260 & VOA & Chloroethane & MW340 & 250 & ug/L & $\mathrm{U}$ & $5 / 23 / 2007$ & $6 / 5 / 2007$ & 250 \\
\hline SW846-8260 & VOA & Chloroethane & MW381 & 5 & $\mathrm{ug} / \mathrm{L}$ & $\mathrm{U}$ & $5 / 22 / 2007$ & $6 / 5 / 2007$ & 5 \\
\hline SW846-8260 & VOA & Chloroethane & MW66 & 100 & ug/L & $U$ & $5 / 15 / 2007$ & $5 / 29 / 2007$ & 100 \\
\hline SW846-8260 & VOA & Chloroethane & QC & 5 & ug/L & $U$ & $5 / 17 / 2007$ & $5 / 30 / 2007$ & 5 \\
\hline SW846-8260 & VOA & Chloroethane & QC & 5 & ug/L & $\mathrm{U}$ & $5 / 21 / 2007$ & $6 / 1 / 2007$ & 5 \\
\hline SW846-8260 & VOA & Chloroethane & QC & 5 & ug/L & $\mathrm{U}$ & $5 / 22 / 2007$ & $6 / 5 / 2007$ & 5 \\
\hline SW846-8260 & VOA & Chloroethane & QC & 5 & ug/L & $U$ & $5 / 15 / 2007$ & $5 / 29 / 2007$ & 5 \\
\hline SW846-8260 & VOA & Chloroethane & QC & 5 & ug/L & $U$ & $5 / 16 / 2007$ & $5 / 30 / 2007$ & 5 \\
\hline SW846-8260 & VOA & Chloroethane & QC & 5 & ug/L & $U$ & $5 / 22 / 2007$ & $6 / 5 / 2007$ & 5 \\
\hline SW846-8260 & VOA & Chloroethane & QC & 5 & ug/L & $U$ & $5 / 22 / 2007$ & $6 / 5 / 2007$ & 5 \\
\hline SW846-8260 & VOA & Chloroethane & QC & 5 & ug/L & $U$ & $5 / 23 / 2007$ & $6 / 5 / 2007$ & 5 \\
\hline SW846-8260 & VOA & Chloroform & MW125 & 25 & $\mathrm{ug} / \mathrm{L}$ & $\mathrm{U}$ & $5 / 21 / 2007$ & $6 / 1 / 2007$ & 25 \\
\hline SW846-8260 & VOA & Chloroform & MW168 & 5 & ug/L & $U$ & $5 / 16 / 2007$ & $5 / 30 / 2007$ & 5 \\
\hline SW846-8260 & VOA & Chloroform & MW185 & 120 & $\mathrm{ug} / \mathrm{L}$ & $\mathrm{U}$ & $5 / 23 / 2007$ & $6 / 5 / 2007$ & 120 \\
\hline SW846-8260 & VOA & Chloroform & MW194 & 5 & ug/L & $U$ & $5 / 17 / 2007$ & $5 / 30 / 2007$ & 5 \\
\hline SW846-8260 & VOA & Chloroform & MW197 & 5 & ug/L & $U$ & $5 / 21 / 2007$ & $6 / 1 / 2007$ & 5 \\
\hline SW846-8260 & VOA & Chloroform & MW236 & 5 & ug/L & $U$ & $5 / 22 / 2007$ & $6 / 5 / 2007$ & 5 \\
\hline SW846-8260 & VOA & Chloroform & MW236 & 5 & ug/L & $U$ & $5 / 22 / 2007$ & $6 / 5 / 2007$ & 5 \\
\hline SW846-8260 & VOA & Chloroform & MW242 & 5 & $\mathrm{ug} / \mathrm{L}$ & $\mathrm{U}$ & $5 / 17 / 2007$ & $5 / 30 / 2007$ & 5 \\
\hline SW846-8260 & VOA & Chloroform & MW243 & 5 & ug/L & $U$ & $5 / 15 / 2007$ & $5 / 29 / 2007$ & 5 \\
\hline SW846-8260 & VOA & Chloroform & MW262 & 50 & $\mathrm{ug} / \mathrm{L}$ & $U$ & $5 / 16 / 2007$ & $5 / 30 / 2007$ & 50 \\
\hline SW846-8260 & VOA & Chloroform & MW340 & 250 & ug/L & $U$ & $5 / 23 / 2007$ & $6 / 5 / 2007$ & 250 \\
\hline SW846-8260 & VOA & Chloroform & MW381 & 5 & $\mathrm{ug} / \mathrm{L}$ & $U$ & $5 / 22 / 2007$ & $6 / 5 / 2007$ & 5 \\
\hline SW846-8260 & VOA & Chloroform & MW66 & 100 & $\mathrm{ug} / \mathrm{L}$ & $\mathrm{U}$ & $5 / 15 / 2007$ & $5 / 29 / 2007$ & 100 \\
\hline SW846-8260 & VOA & Chloroform & QC & 5 & ug/L & $U$ & $5 / 17 / 2007$ & $5 / 30 / 2007$ & 5 \\
\hline SW846-8260 & VOA & Chloroform & QC & 5 & ug/L & $\mathrm{U}$ & $5 / 15 / 2007$ & $5 / 29 / 2007$ & 5 \\
\hline SW846-8260 & VOA & Chloroform & QC & 5 & ug/L & $\mathrm{U}$ & $5 / 21 / 2007$ & $6 / 1 / 2007$ & 5 \\
\hline SW846-8260 & VOA & Chloroform & QC & 5 & ug/L & $U$ & $5 / 22 / 2007$ & $6 / 5 / 2007$ & 5 \\
\hline SW846-8260 & VOA & Chloroform & QC & 5 & $\mathrm{ug} / \mathrm{L}$ & $\mathrm{U}$ & $5 / 16 / 2007$ & $5 / 30 / 2007$ & 5 \\
\hline SW846-8260 & VOA & Chloroform & QC & 5 & ug/L & $U$ & $5 / 22 / 2007$ & $6 / 5 / 2007$ & 5 \\
\hline SW846-8260 & VOA & Chloroform & QC & 5 & $\mathrm{ug} / \mathrm{L}$ & $U$ & $5 / 22 / 2007$ & $6 / 5 / 2007$ & 5 \\
\hline SW846-8260 & VOA & Chloroform & QC & 5 & ug/L & $U$ & $5 / 23 / 2007$ & $6 / 5 / 2007$ & 5 \\
\hline SW846-8260 & VOA & Chloromethane & MW125 & 25 & ug/L & $\mathrm{JU}$ & $5 / 21 / 2007$ & $6 / 1 / 2007$ & 25 \\
\hline SW846-8260 & VOA & Chloromethane & MW168 & 5 & $\mathrm{ug} / \mathrm{L}$ & $U$ & $5 / 16 / 2007$ & $5 / 30 / 2007$ & 5 \\
\hline SW846-8260 & VOA & Chloromethane & MW185 & 120 & $\mathrm{ug} / \mathrm{L}$ & $\mathrm{JU}$ & $5 / 23 / 2007$ & $6 / 5 / 2007$ & 120 \\
\hline SW846-8260 & VOA & Chloromethane & MW194 & 5 & $\mathrm{ug} / \mathrm{L}$ & $\mathrm{U}$ & $5 / 17 / 2007$ & $5 / 30 / 2007$ & 5 \\
\hline SW846-8260 & VOA & Chloromethane & MW197 & 5 & ug/L & $\mathrm{JU}$ & $5 / 21 / 2007$ & $6 / 1 / 2007$ & 5 \\
\hline SW846-8260 & VOA & Chloromethane & MW236 & 5 & $\mathrm{ug} / \mathrm{L}$ & $\mathrm{JU}$ & $5 / 22 / 2007$ & $6 / 5 / 2007$ & 5 \\
\hline SW846-8260 & VOA & Chloromethane & MW236 & 5 & ug/L & $\mathrm{JU}$ & $5 / 22 / 2007$ & $6 / 5 / 2007$ & 5 \\
\hline SW846-8260 & VOA & Chloromethane & MW242 & 5 & $\mathrm{ug} / \mathrm{L}$ & $\mathrm{U}$ & $5 / 17 / 2007$ & $5 / 30 / 2007$ & 5 \\
\hline SW846-8260 & VOA & Chloromethane & MW243 & 5 & ug/L & $U$ & $5 / 15 / 2007$ & $5 / 29 / 2007$ & 5 \\
\hline SW846-8260 & VOA & Chloromethane & MW262 & 50 & $\mathrm{ug} / \mathrm{L}$ & $U$ & $5 / 16 / 2007$ & $5 / 30 / 2007$ & 50 \\
\hline SW846-8260 & VOA & Chloromethane & MW340 & 250 & $\mathrm{ug} / \mathrm{L}$ & $\mathrm{JU}$ & $5 / 23 / 2007$ & $6 / 5 / 2007$ & 250 \\
\hline SW846-8260 & VOA & Chloromethane & MW381 & 5 & ug/L & $\mathrm{JU}$ & $5 / 22 / 2007$ & $6 / 5 / 2007$ & 5 \\
\hline SW846-8260 & VOA & Chloromethane & MW66 & 100 & $\mathrm{ug} / \mathrm{L}$ & $U$ & $5 / 15 / 2007$ & $5 / 29 / 2007$ & 100 \\
\hline SW846-8260 & VOA & Chloromethane & QC & 5 & $\mathrm{ug} / \mathrm{L}$ & $U$ & $5 / 17 / 2007$ & $5 / 30 / 2007$ & 5 \\
\hline SW846-8260 & VOA & Chloromethane & QC & 5 & $\mathrm{ug} / \mathrm{L}$ & $\mathrm{JU}$ & $5 / 21 / 2007$ & $6 / 1 / 2007$ & 5 \\
\hline SW846-8260 & VOA & Chloromethane & QC & 5 & $\mathrm{ug} / \mathrm{L}$ & $\mathrm{JU}$ & $5 / 22 / 2007$ & $6 / 5 / 2007$ & 5 \\
\hline SW846-8260 & VOA & Chloromethane & QC & 5 & ug/L & $\mathrm{U}$ & $5 / 15 / 2007$ & $5 / 29 / 2007$ & 5 \\
\hline SW846-8260 & VOA & Chloromethane & QC & 5 & $\mathrm{ug} / \mathrm{L}$ & $U$ & $5 / 16 / 2007$ & $5 / 30 / 2007$ & 5 \\
\hline SW846-8260 & VOA & Chloromethane & QC & 5 & ug/L & $\mathrm{JU}$ & $5 / 22 / 2007$ & $6 / 5 / 2007$ & 5 \\
\hline SW846-8260 & VOA & Chloromethane & QC & 5 & ug/L & $\mathrm{JU}$ & $5 / 22 / 2007$ & $6 / 5 / 2007$ & 5 \\
\hline SW846-8260 & VOA & Chloromethane & QC & 5 & $\mathrm{ug} / \mathrm{L}$ & $\mathrm{JU}$ & $5 / 23 / 2007$ & $6 / 5 / 2007$ & 5 \\
\hline
\end{tabular}




\begin{tabular}{|c|c|c|c|c|c|c|c|c|c|}
\hline Method & AnaType & Chemical Name & Station & Results & Units & $\begin{array}{c}\text { Result } \\
\text { Qualifier }\end{array}$ & Date Collected & $\begin{array}{c}\text { Date } \\
\text { Analyzed }\end{array}$ & $\begin{array}{l}\text { Detection } \\
\text { Limit }\end{array}$ \\
\hline SW846-8260 & VOA & cis-1,2-Dichloroethene & MW125 & 25 & $u g / L$ & U & $5 / 21 / 2007$ & $6 / 1 / 2007$ & 25 \\
\hline SW846-8260 & VOA & cis-1,2-Dichloroethene & MW168 & 5 & $\mathrm{ug} / \mathrm{L}$ & $u$ & $5 / 16 / 2007$ & $5 / 30 / 2007$ & 5 \\
\hline SW846-8260 & VOA & cis-1,2-Dichloroethene & MW185 & 140 & $\mathrm{ug} / \mathrm{L}$ & D & $5 / 23 / 2007$ & $6 / 5 / 2007$ & 120 \\
\hline SW846-8260 & VOA & cis-1,2-Dichloroethene & MW194 & 5 & $\mathrm{ug} / \mathrm{L}$ & $\mathrm{u}$ & $5 / 17 / 2007$ & $5 / 30 / 2007$ & 5 \\
\hline SW846-8260 & VOA & cis-1,2-Dichloroethene & MW197 & 5 & $\mathrm{ug} / \mathrm{L}$ & $\mathrm{U}$ & $5 / 21 / 2007$ & $6 / 1 / 2007$ & 5 \\
\hline SW846-8260 & VOA & cis-1,2-Dichloroethene & MW236 & 5 & $u g / L$ & $\mathrm{U}$ & $5 / 22 / 2007$ & $6 / 5 / 2007$ & 5 \\
\hline SW846-8260 & VOA & cis-1,2-Dichloroethene & MW236 & 5 & $\mathrm{ug} / \mathrm{L}$ & $\mathrm{U}$ & $5 / 22 / 2007$ & $6 / 5 / 2007$ & 5 \\
\hline SW846-8260 & VOA & cis-1,2-Dichloroethene & MW242 & 5 & $\mathrm{ug} / \mathrm{L}$ & $\mathrm{U}$ & $5 / 17 / 2007$ & $5 / 30 / 2007$ & 5 \\
\hline SW846-8260 & VOA & cis-1,2-Dichloroethene & MW243 & 5 & $\mathrm{ug} / \mathrm{L}$ & $\mathrm{U}$ & $5 / 15 / 2007$ & $5 / 29 / 2007$ & 5 \\
\hline SW846-8260 & VOA & cis-1,2-Dichloroethene & MW262 & 50 & $\mathrm{ug} / \mathrm{L}$ & $\mathrm{u}$ & $5 / 16 / 2007$ & $5 / 30 / 2007$ & 50 \\
\hline SW846-8260 & VOA & cis-1,2-Dichloroethene & MW340 & 250 & $\mathrm{ug} / \mathrm{L}$ & u & $5 / 23 / 2007$ & $6 / 5 / 2007$ & 250 \\
\hline SW846-8260 & VOA & cis-1,2-Dichloroethene & MW381 & 5 & $\mathrm{ug} / \mathrm{L}$ & $\mathrm{U}$ & $5 / 22 / 2007$ & $6 / 5 / 2007$ & 5 \\
\hline SW846-8260 & VOA & cis-1,2-Dichloroethene & MW66 & 100 & ug/L & $\mathrm{U}$ & $5 / 15 / 2007$ & $5 / 29 / 2007$ & 100 \\
\hline SW846-8260 & VOA & cis-1,2-Dichloroethene & QC & 5 & $\mathrm{ug} / \mathrm{L}$ & $\mathrm{U}$ & $5 / 17 / 2007$ & $5 / 30 / 2007$ & 5 \\
\hline SW846-8260 & VOA & cis-1,2-Dichloroethene & QC & 5 & $\mathrm{ug} / \mathrm{L}$ & $\mathrm{U}$ & $5 / 21 / 2007$ & $6 / 1 / 2007$ & 5 \\
\hline SW846-8260 & VOA & cis-1,2-Dichloroethene & $\mathrm{QC}$ & 5 & $\mathrm{ug} / \mathrm{L}$ & $\mathrm{u}$ & $5 / 22 / 2007$ & $6 / 5 / 2007$ & 5 \\
\hline SW846-8260 & VOA & cis-1,2-Dichloroethene & $\mathrm{QC}$ & 5 & $\mathrm{ug} / \mathrm{L}$ & $\mathrm{U}$ & $5 / 15 / 2007$ & $5 / 29 / 2007$ & 5 \\
\hline SW846-8260 & VOA & cis-1,2-Dichloroethene & $\mathrm{QC}$ & 5 & $\mathrm{ug} / \mathrm{L}$ & $\mathrm{u}$ & $5 / 16 / 2007$ & $5 / 30 / 2007$ & 5 \\
\hline SW846-8260 & VOA & cis-1,2-Dichloroethene & $\mathrm{QC}$ & 5 & $\mathrm{ug} / \mathrm{L}$ & $\mathrm{u}$ & $5 / 22 / 2007$ & $6 / 5 / 2007$ & 5 \\
\hline SW846-8260 & VOA & cis-1,2-Dichloroethene & $\mathrm{QC}$ & 5 & $\mathrm{ug} / \mathrm{L}$ & $\mathrm{u}$ & $5 / 22 / 2007$ & $6 / 5 / 2007$ & 5 \\
\hline SW846-8260 & VOA & cis-1,2-Dichloroethene & QC & 5 & $\mathrm{ug} / \mathrm{L}$ & $\mathrm{U}$ & $5 / 23 / 2007$ & $6 / 5 / 2007$ & 5 \\
\hline SW846-8260 & VOA & cis-1,3-Dichloropropene & MW125 & 25 & $\mathrm{ug} / \mathrm{L}$ & $\mathrm{u}$ & $5 / 21 / 2007$ & $6 / 1 / 2007$ & 25 \\
\hline SW846-8260 & VOA & cis-1,3-Dichloropropene & MW168 & 5 & $\mathrm{ug} / \mathrm{L}$ & $\mathrm{u}$ & $5 / 16 / 2007$ & $5 / 30 / 2007$ & 5 \\
\hline SW846-8260 & VOA & cis-1,3-Dichloropropene & MW185 & 120 & $\mathrm{ug} / \mathrm{L}$ & $\mathrm{u}$ & $5 / 23 / 2007$ & $6 / 5 / 2007$ & 120 \\
\hline SW846-8260 & VOA & cis-1,3-Dichloropropene & MW194 & 5 & $\mathrm{ug} / \mathrm{L}$ & $\mathrm{u}$ & $5 / 17 / 2007$ & $5 / 30 / 2007$ & 5 \\
\hline SW846-8260 & VOA & cis-1,3-Dichloropropene & MW197 & 5 & $\mathrm{ug} / \mathrm{L}$ & $\mathrm{U}$ & $5 / 21 / 2007$ & $6 / 1 / 2007$ & 5 \\
\hline SW846-8260 & VOA & cis-1,3-Dichloropropene & MW236 & 5 & $\mathrm{ug} / \mathrm{L}$ & $\mathrm{u}$ & $5 / 22 / 2007$ & $6 / 5 / 2007$ & 5 \\
\hline SW846-8260 & VOA & cis-1,3-Dichloropropene & MW236 & 5 & $\mathrm{ug} / \mathrm{L}$ & $\mathrm{U}$ & $5 / 22 / 2007$ & $6 / 5 / 2007$ & 5 \\
\hline SW846-8260 & VOA & cis-1,3-Dichloropropene & MW242 & 5 & $\mathrm{ug} / \mathrm{L}$ & $\mathrm{u}$ & $5 / 17 / 2007$ & $5 / 30 / 2007$ & 5 \\
\hline SW846-8260 & VOA & cis-1,3-Dichloropropene & MW243 & 5 & $\mathrm{ug} / \mathrm{L}$ & $\mathrm{u}$ & $5 / 15 / 2007$ & $5 / 29 / 2007$ & 5 \\
\hline SW846-8260 & VOA & cis-1,3-Dichloropropene & MW262 & 50 & $\mathrm{ug} / \mathrm{L}$ & $\mathrm{u}$ & $5 / 16 / 2007$ & $5 / 30 / 2007$ & 50 \\
\hline SW846-8260 & VOA & cis-1,3-Dichloropropene & MW340 & 250 & $\mathrm{ug} / \mathrm{L}$ & $\mathrm{u}$ & $5 / 23 / 2007$ & $6 / 5 / 2007$ & 250 \\
\hline SW846-8260 & VOA & cis-1,3-Dichloropropene & MW381 & 5 & $\mathrm{ug} / \mathrm{L}$ & $\mathrm{U}$ & $5 / 22 / 2007$ & $6 / 5 / 2007$ & 5 \\
\hline SW846-8260 & VOA & cis-1,3-Dichloropropene & MW66 & 100 & $u g / L$ & $\mathrm{u}$ & $5 / 15 / 2007$ & $5 / 29 / 2007$ & 100 \\
\hline SW846-8260 & VOA & cis-1,3-Dichloropropene & QC & 5 & $\mathrm{ug} / \mathrm{L}$ & $\mathrm{U}$ & $5 / 17 / 2007$ & $5 / 30 / 2007$ & 5 \\
\hline SW846-8260 & VOA & cis-1,3-Dichloropropene & QC & 5 & $\mathrm{ug} / \mathrm{L}$ & $\mathrm{u}$ & $5 / 15 / 2007$ & $5 / 29 / 2007$ & 5 \\
\hline SW846-8260 & VOA & cis-1,3-Dichloropropene & $\mathrm{QC}$ & 5 & $\mathrm{ug} / \mathrm{L}$ & $\mathrm{u}$ & $5 / 21 / 2007$ & $6 / 1 / 2007$ & 5 \\
\hline SW846-8260 & VOA & cis-1,3-Dichloropropene & $\mathrm{QC}$ & 5 & $u g / L$ & $\mathrm{U}$ & $5 / 22 / 2007$ & $6 / 5 / 2007$ & 5 \\
\hline SW846-8260 & VOA & cis-1,3-Dichloropropene & $\mathrm{QC}$ & 5 & $\mathrm{ug} / \mathrm{L}$ & $\mathrm{u}$ & $5 / 16 / 2007$ & $5 / 30 / 2007$ & 5 \\
\hline SW846-8260 & VOA & cis-1,3-Dichloropropene & QC & 5 & $\mathrm{ug} / \mathrm{L}$ & $\mathrm{U}$ & $5 / 22 / 2007$ & $6 / 5 / 2007$ & 5 \\
\hline SW846-8260 & VOA & cis-1,3-Dichloropropene & $\mathrm{QC}$ & 5 & $\mathrm{ug} / \mathrm{L}$ & $\mathrm{u}$ & $5 / 22 / 2007$ & $6 / 5 / 2007$ & 5 \\
\hline SW846-8260 & VOA & cis-1,3-Dichloropropene & $\mathrm{QC}$ & 5 & $u g / L$ & $\mathrm{u}$ & $5 / 23 / 2007$ & $6 / 5 / 2007$ & 5 \\
\hline RSK175 & VOA & $\mathrm{CO} 2$ & MW125 & 76100 & $\mathrm{ug} / \mathrm{L}$ & & $5 / 21 / 2007$ & $5 / 23 / 2007$ & 13480 \\
\hline RSK175 & VOA & $\mathrm{CO} 2$ & MW168 & 110000 & $\mathrm{ug} / \mathrm{L}$ & & $5 / 16 / 2007$ & $5 / 18 / 2007$ & 13480 \\
\hline RSK175 & VOA & $\mathrm{CO} 2$ & MW185 & 74100 & $\mathrm{ug} / \mathrm{L}$ & & $5 / 23 / 2007$ & $5 / 29 / 2007$ & 13480 \\
\hline RSK175 & VOA & $\mathrm{CO} 2$ & MW194 & 52700 & $u g / L$ & & $5 / 17 / 2007$ & $5 / 22 / 2007$ & 13480 \\
\hline RSK175 & VOA & $\mathrm{CO} 2$ & MW197 & 78900 & ug/L & & $5 / 21 / 2007$ & $5 / 23 / 2007$ & 13480 \\
\hline RSK175 & VOA & $\mathrm{CO} 2$ & MW236 & 61800 & $\mathrm{ug} / \mathrm{L}$ & & $5 / 22 / 2007$ & $5 / 23 / 2007$ & 13480 \\
\hline RSK175 & VOA & $\mathrm{CO} 2$ & MW236 & 65800 & ug/L & & $5 / 22 / 2007$ & $5 / 23 / 2007$ & 13480 \\
\hline RSK175 & VOA & $\mathrm{CO} 2$ & MW242 & 94700 & $\mathrm{ug} / \mathrm{L}$ & & $5 / 17 / 2007$ & $5 / 22 / 2007$ & 13480 \\
\hline RSK175 & VOA & $\mathrm{CO} 2$ & MW243 & 74800 & $\mathrm{ug} / \mathrm{L}$ & & $5 / 15 / 2007$ & $5 / 18 / 2007$ & 13480 \\
\hline RSK175 & VOA & $\mathrm{CO} 2$ & MW262 & 110000 & ug/L & & $5 / 16 / 2007$ & $5 / 18 / 2007$ & 13480 \\
\hline RSK175 & VOA & $\mathrm{CO} 2$ & MW340 & 204000 & $\mathrm{ug} / \mathrm{L}$ & & $5 / 23 / 2007$ & $5 / 29 / 2007$ & 13480 \\
\hline RSK175 & VOA & $\mathrm{CO} 2$ & MW381 & 60500 & ug/L & & $5 / 22 / 2007$ & $5 / 23 / 2007$ & 13480 \\
\hline RSK175 & VOA & $\mathrm{CO} 2$ & MW66 & 57400 & ug/L & & $5 / 15 / 2007$ & $5 / 18 / 2007$ & 13480 \\
\hline RSK175 & VOA & $\mathrm{CO} 2$ & QC & 674 & ug/L & $U$ & $5 / 17 / 2007$ & $5 / 22 / 2007$ & 674 \\
\hline RSK175 & VOA & $\mathrm{CO} 2$ & QC & 674 & $\mathrm{ug} / \mathrm{L}$ & $u$ & $5 / 15 / 2007$ & $5 / 18 / 2007$ & 674 \\
\hline RSK175 & VOA & $\mathrm{CO} 2$ & $\mathrm{QC}$ & 674 & ug/L & $u$ & $5 / 21 / 2007$ & $5 / 23 / 2007$ & 674 \\
\hline RSK175 & VOA & $\mathrm{CO} 2$ & $\mathrm{QC}$ & 674 & ug/L & U & $5 / 22 / 2007$ & $5 / 23 / 2007$ & 674 \\
\hline RSK175 & VOA & $\mathrm{CO} 2$ & QC & 674 & ug/L & U & $5 / 16 / 2007$ & $5 / 18 / 2007$ & 674 \\
\hline RSK175 & VOA & $\mathrm{CO} 2$ & QC & 674 & $\mathrm{ug} / \mathrm{L}$ & U & $5 / 22 / 2007$ & $5 / 23 / 2007$ & 674 \\
\hline RSK175 & VOA & $\mathrm{CO} 2$ & $\mathrm{QC}$ & 674 & $\mathrm{ug} / \mathrm{L}$ & $u$ & $5 / 22 / 2007$ & $5 / 23 / 2007$ & 674 \\
\hline RSK175 & VOA & $\mathrm{CO} 2$ & QC & 674 & $\mathrm{ug} / \mathrm{L}$ & $u$ & $5 / 23 / 2007$ & $5 / 29 / 2007$ & 674 \\
\hline SW846-8260 & VOA & Dibromochloromethane & MW125 & 25 & $\mathrm{ug} / \mathrm{L}$ & $\mathrm{U}$ & $5 / 21 / 2007$ & $6 / 1 / 2007$ & 25 \\
\hline SW846-8260 & VOA & Dibromochloromethane & MW168 & 5 & $\mathrm{ug} / \mathrm{L}$ & $\mathrm{U}$ & $5 / 16 / 2007$ & $5 / 30 / 2007$ & 5 \\
\hline SW846-8260 & VOA & Dibromochloromethane & MW185 & 120 & $\mathrm{ug} / \mathrm{L}$ & $\mathrm{U}$ & $5 / 23 / 2007$ & $6 / 5 / 2007$ & 120 \\
\hline SW846-8260 & VOA & Dibromochloromethane & MW194 & 5 & ug/L & $\mathrm{U}$ & $5 / 17 / 2007$ & $5 / 30 / 2007$ & 5 \\
\hline SW846-8260 & VOA & Dibromochloromethane & MW197 & 5 & $\mathrm{ug} / \mathrm{L}$ & $\mathrm{U}$ & $5 / 21 / 2007$ & $6 / 1 / 2007$ & 5 \\
\hline SW846-8260 & VOA & Dibromochloromethane & MW236 & 5 & $u g / L$ & $\mathrm{U}$ & $5 / 22 / 2007$ & $6 / 5 / 2007$ & 5 \\
\hline
\end{tabular}




\begin{tabular}{|c|c|c|c|c|c|c|c|c|c|}
\hline Method & AnaType & Chemical Name & Station & Results & Units & $\begin{array}{c}\text { Result } \\
\text { Qualifier }\end{array}$ & Date Collected & $\begin{array}{c}\text { Date } \\
\text { Analyzed }\end{array}$ & $\begin{array}{l}\text { Detection } \\
\text { Limit }\end{array}$ \\
\hline SW846-8260 & VOA & Dibromochloromethane & MW236 & 5 & ug/L & U & $5 / 22 / 2007$ & $6 / 5 / 2007$ & 5 \\
\hline SW846-8260 & VOA & Dibromochloromethane & MW242 & 5 & ug/L & $\mathrm{U}$ & $5 / 17 / 2007$ & $5 / 30 / 2007$ & 5 \\
\hline SW846-8260 & VOA & Dibromochloromethane & MW243 & 5 & $\mathrm{ug} / \mathrm{L}$ & $\mathrm{U}$ & $5 / 15 / 2007$ & $5 / 29 / 2007$ & 5 \\
\hline SW846-8260 & VOA & Dibromochloromethane & MW262 & 50 & ug/L & $\mathrm{U}$ & $5 / 16 / 2007$ & $5 / 30 / 2007$ & 50 \\
\hline SW846-8260 & VOA & Dibromochloromethane & MW340 & 250 & ug/L & $\mathrm{U}$ & $5 / 23 / 2007$ & $6 / 5 / 2007$ & 250 \\
\hline SW846-8260 & VOA & Dibromochloromethane & MW381 & 5 & ug/L & $\mathrm{U}$ & $5 / 22 / 2007$ & $6 / 5 / 2007$ & 5 \\
\hline SW846-8260 & VOA & Dibromochloromethane & MW66 & 100 & $\mathrm{ug} / \mathrm{L}$ & $\mathrm{U}$ & $5 / 15 / 2007$ & $5 / 29 / 2007$ & 100 \\
\hline SW846-8260 & VOA & Dibromochloromethane & $\mathrm{QC}$ & 5 & ug/L & $\mathrm{U}$ & $5 / 17 / 2007$ & $5 / 30 / 2007$ & 5 \\
\hline SW846-8260 & VOA & Dibromochloromethane & QC & 5 & $\mathrm{ug} / \mathrm{L}$ & $\mathrm{U}$ & $5 / 21 / 2007$ & $6 / 1 / 2007$ & 5 \\
\hline SW846-8260 & VOA & Dibromochloromethane & QC & 5 & $\mathrm{ug} / \mathrm{L}$ & $\mathrm{U}$ & $5 / 22 / 2007$ & $6 / 5 / 2007$ & 5 \\
\hline SW846-8260 & VOA & Dibromochloromethane & QC & 5 & $\mathrm{ug} / \mathrm{L}$ & $\mathrm{U}$ & $5 / 15 / 2007$ & $5 / 29 / 2007$ & 5 \\
\hline SW846-8260 & VOA & Dibromochloromethane & QC & 5 & $\mathrm{ug} / \mathrm{L}$ & $\mathrm{U}$ & $5 / 22 / 2007$ & $6 / 5 / 2007$ & 5 \\
\hline SW846-8260 & VOA & Dibromochloromethane & QC & 5 & ug/L & $U$ & $5 / 22 / 2007$ & $6 / 5 / 2007$ & 5 \\
\hline SW846-8260 & VOA & Dibromochloromethane & QC & 5 & $\mathrm{ug} / \mathrm{L}$ & $\mathrm{U}$ & $5 / 23 / 2007$ & $6 / 5 / 2007$ & 5 \\
\hline SW846-8260 & VOA & Ethylbenzene & MW125 & 25 & ug/L & $\mathrm{U}$ & $5 / 21 / 2007$ & $6 / 1 / 2007$ & 25 \\
\hline SW846-8260 & VOA & Ethylbenzene & MW185 & 120 & $\mathrm{ug} / \mathrm{L}$ & $\mathrm{U}$ & $5 / 23 / 2007$ & $6 / 5 / 2007$ & 120 \\
\hline SW846-8260 & VOA & Ethylbenzene & MW194 & 5 & $\mathrm{ug} / \mathrm{L}$ & $\mathrm{U}$ & $5 / 17 / 2007$ & $5 / 30 / 2007$ & 5 \\
\hline SW846-8260 & VOA & Ethylbenzene & MW197 & 5 & $\mathrm{ug} / \mathrm{L}$ & $\mathrm{U}$ & $5 / 21 / 2007$ & $6 / 1 / 2007$ & 5 \\
\hline SW846-8260 & VOA & Ethylbenzene & MW236 & 5 & ug/L & $\mathrm{U}$ & $5 / 22 / 2007$ & $6 / 5 / 2007$ & 5 \\
\hline SW846-8260 & VOA & Ethylbenzene & MW236 & 5 & $\mathrm{ug} / \mathrm{L}$ & $\mathrm{U}$ & $5 / 22 / 2007$ & $6 / 5 / 2007$ & 5 \\
\hline SW846-8260 & VOA & Ethylbenzene & MW242 & 5 & $\mathrm{ug} / \mathrm{L}$ & $\mathrm{U}$ & $5 / 17 / 2007$ & $5 / 30 / 2007$ & 5 \\
\hline SW846-8260 & VOA & Ethylbenzene & MW243 & 5 & $\mathrm{ug} / \mathrm{L}$ & $\mathrm{U}$ & $5 / 15 / 2007$ & $5 / 29 / 2007$ & 5 \\
\hline SW846-8260 & VOA & Ethylbenzene & MW262 & 50 & ug/L & $\mathrm{U}$ & $5 / 16 / 2007$ & $5 / 30 / 2007$ & 50 \\
\hline SW846-8260 & VOA & Ethylbenzene & MW340 & 250 & $\mathrm{ug} / \mathrm{L}$ & $\mathrm{U}$ & $5 / 23 / 2007$ & $6 / 5 / 2007$ & 250 \\
\hline SW846-8260 & VOA & Ethylbenzene & MW381 & 5 & ug/L & $U$ & $5 / 22 / 2007$ & $6 / 5 / 2007$ & 5 \\
\hline SW846-8260 & VOA & Ethylbenzene & MW66 & 100 & ug/L & $\mathrm{U}$ & $5 / 15 / 2007$ & $5 / 29 / 2007$ & 100 \\
\hline SW846-8260 & VOA & Ethylbenzene & QC & 5 & ug/L & $\mathrm{U}$ & $5 / 17 / 2007$ & $5 / 30 / 2007$ & 5 \\
\hline SW846-8260 & VOA & Ethylbenzene & QC & 5 & ug/L & $\mathrm{U}$ & $5 / 21 / 2007$ & $6 / 1 / 2007$ & 5 \\
\hline SW846-8260 & VOA & Ethylbenzene & $\mathrm{QC}$ & 5 & $\mathrm{ug} / \mathrm{L}$ & $\mathrm{U}$ & $5 / 22 / 2007$ & $6 / 5 / 2007$ & 5 \\
\hline SW846-8260 & VOA & Ethylbenzene & $\mathrm{QC}$ & 5 & $\mathrm{ug} / \mathrm{L}$ & $\mathrm{U}$ & $5 / 15 / 2007$ & $5 / 29 / 2007$ & 5 \\
\hline SW846-8260 & VOA & Ethylbenzene & QC & 5 & ug/L & $\mathrm{U}$ & $5 / 16 / 2007$ & $5 / 30 / 2007$ & 5 \\
\hline SW846-8260 & VOA & Ethylbenzene & QC & 5 & ug/L & $U$ & $5 / 23 / 2007$ & $6 / 5 / 2007$ & 5 \\
\hline SW846-8260 & VOA & m,p-Xylene & MW125 & 50 & ug/L & $U$ & $5 / 21 / 2007$ & $6 / 1 / 2007$ & 50 \\
\hline SW846-8260 & VOA & m,p-Xylene & MW168 & 10 & ug/L & $U$ & $5 / 16 / 2007$ & $5 / 30 / 2007$ & 10 \\
\hline SW846-8260 & VOA & m,p-Xylene & MW185 & 250 & $\mathrm{ug} / \mathrm{L}$ & $\mathrm{U}$ & $5 / 23 / 2007$ & $6 / 5 / 2007$ & 250 \\
\hline SW846-8260 & VOA & m,p-Xylene & MW194 & 10 & ug/L & $\mathrm{U}$ & $5 / 17 / 2007$ & $5 / 30 / 2007$ & 10 \\
\hline SW846-8260 & VOA & m,p-Xylene & MW197 & 10 & ug/L & $\mathrm{U}$ & $5 / 21 / 2007$ & $6 / 1 / 2007$ & 10 \\
\hline SW846-8260 & VOA & m,p-Xylene & MW236 & 10 & ug/L & $\mathrm{U}$ & $5 / 22 / 2007$ & $6 / 5 / 2007$ & 10 \\
\hline SW846-8260 & VOA & m,p-Xylene & MW236 & 10 & ug/L & $U$ & $5 / 22 / 2007$ & 6/5/2007 & 10 \\
\hline SW846-8260 & VOA & $\mathrm{m}, \mathrm{p}$-Xylene & MW242 & 10 & $\mathrm{ug} / \mathrm{L}$ & $\mathrm{U}$ & $5 / 17 / 2007$ & $5 / 30 / 2007$ & 10 \\
\hline SW846-8260 & VOA & m,p-Xylene & MW243 & 10 & ug/L & $\mathrm{U}$ & $5 / 15 / 2007$ & $5 / 29 / 2007$ & 10 \\
\hline SW846-8260 & VOA & m,p-Xylene & MW262 & 100 & $\mathrm{ug} / \mathrm{L}$ & $\mathrm{U}$ & $5 / 16 / 2007$ & $5 / 30 / 2007$ & 100 \\
\hline SW846-8260 & VOA & m,p-Xylene & MW340 & 500 & ug/L & $\mathrm{U}$ & $5 / 23 / 2007$ & $6 / 5 / 2007$ & 500 \\
\hline SW846-8260 & VOA & m,p-Xylene & MW381 & 10 & ug/L & $U$ & $5 / 22 / 2007$ & $6 / 5 / 2007$ & 10 \\
\hline SW846-8260 & VOA & m,p-Xylene & MW66 & 200 & $\mathrm{ug} / \mathrm{L}$ & $\mathrm{U}$ & $5 / 15 / 2007$ & $5 / 29 / 2007$ & 200 \\
\hline SW846-8260 & VOA & m,p-Xylene & QC & 10 & ug/L & $\mathrm{U}$ & $5 / 16 / 2007$ & $5 / 30 / 2007$ & 10 \\
\hline SW846-8260 & VOA & m,p-Xylene & QC & 10 & $\mathrm{ug} / \mathrm{L}$ & $\mathrm{U}$ & $5 / 17 / 2007$ & $5 / 30 / 2007$ & 10 \\
\hline SW846-8260 & VOA & m,p-Xylene & QC & 10 & ug/L & $\mathrm{U}$ & $5 / 21 / 2007$ & $6 / 1 / 2007$ & 10 \\
\hline SW846-8260 & VOA & m,p-Xylene & QC & 10 & ug/L & $\mathrm{U}$ & $5 / 15 / 2007$ & $5 / 29 / 2007$ & 10 \\
\hline SW846-8260 & VOA & m,p-Xylene & QC & 10 & ug/L & $\mathrm{U}$ & $5 / 22 / 2007$ & $6 / 5 / 2007$ & 10 \\
\hline SW846-8260 & VOA & m,p-Xylene & QC & 10 & ug/L & $U$ & $5 / 22 / 2007$ & $6 / 5 / 2007$ & 10 \\
\hline SW846-8260 & VOA & m,p-Xylene & QC & 10 & ug/L & $U$ & $5 / 22 / 2007$ & $6 / 5 / 2007$ & 10 \\
\hline SW846-8260 & VOA & m,p-Xylene & QC & 10 & $\mathrm{ug} / \mathrm{L}$ & $\mathrm{U}$ & $5 / 23 / 2007$ & $6 / 5 / 2007$ & 10 \\
\hline RSK175 & VOA & Methane & MW125 & 0.32 & ug/L & $U$ & $5 / 21 / 2007$ & $5 / 23 / 2007$ & 0.32 \\
\hline RSK175 & VOA & Methane & MW168 & 0.32 & ug/L & $\mathrm{U}$ & $5 / 16 / 2007$ & $5 / 18 / 2007$ & 0.32 \\
\hline RSK175 & VOA & Methane & MW185 & 0.32 & ug/L & $\mathrm{U}$ & $5 / 23 / 2007$ & $5 / 29 / 2007$ & 0.32 \\
\hline RSK175 & VOA & Methane & MW194 & 0.32 & ug/L & $U$ & $5 / 17 / 2007$ & $5 / 21 / 2007$ & 0.32 \\
\hline RSK175 & VOA & Methane & MW197 & 27.7 & ug/L & & $5 / 21 / 2007$ & $5 / 23 / 2007$ & 0.32 \\
\hline RSK175 & VOA & Methane & MW236 & 0.32 & $\mathrm{ug} / \mathrm{L}$ & $\mathrm{U}$ & $5 / 22 / 2007$ & $5 / 23 / 2007$ & 0.32 \\
\hline RSK175 & VOA & Methane & MW236 & 0.32 & ug/L & $\mathrm{U}$ & $5 / 22 / 2007$ & $5 / 23 / 2007$ & 0.32 \\
\hline RSK175 & VOA & Methane & MW242 & 0.32 & ug/L & $U$ & $5 / 17 / 2007$ & $5 / 21 / 2007$ & 0.32 \\
\hline RSK175 & VOA & Methane & MW243 & 0.5 & ug/L & & $5 / 15 / 2007$ & $5 / 17 / 2007$ & 0.32 \\
\hline RSK175 & VOA & Methane & MW262 & 0.32 & ug/L & U & $5 / 16 / 2007$ & $5 / 18 / 2007$ & 0.32 \\
\hline RSK175 & VOA & Methane & MW340 & 0.32 & $\mathrm{ug} / \mathrm{L}$ & $U$ & $5 / 23 / 2007$ & $5 / 29 / 2007$ & 0.32 \\
\hline
\end{tabular}




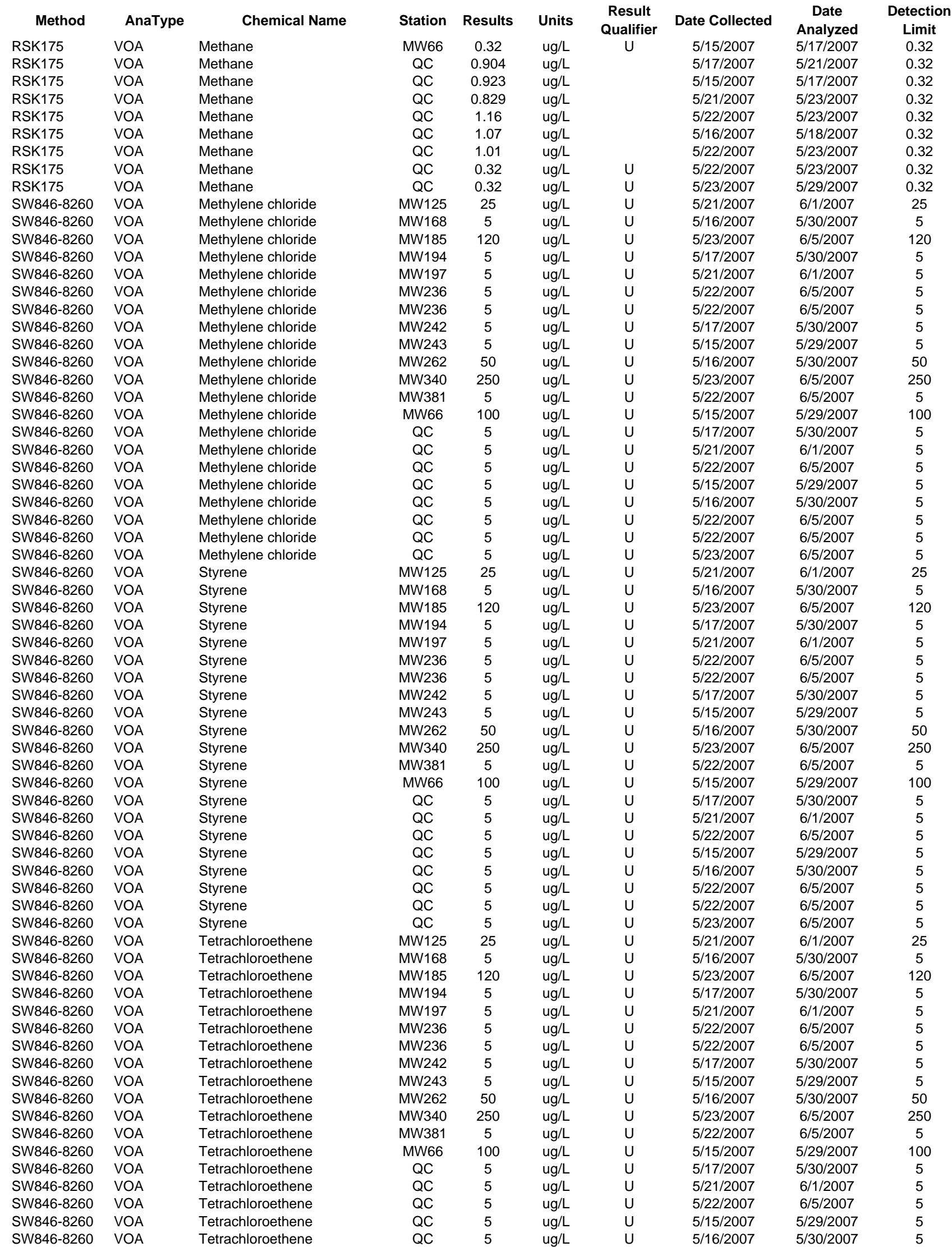




\begin{tabular}{|c|c|c|c|c|c|c|c|c|c|}
\hline Method & AnaType & Chemical Name & Station & Results & Units & $\begin{array}{c}\text { Result } \\
\text { Qualifier }\end{array}$ & Date Collected & $\begin{array}{c}\text { Date } \\
\text { Analyzed }\end{array}$ & $\begin{array}{l}\text { Detection } \\
\text { Limit }\end{array}$ \\
\hline SW846-8260 & VOA & Tetrachloroethene & $\mathrm{QC}$ & 5 & $u g / L$ & $\mathrm{U}$ & $5 / 22 / 2007$ & $6 / 5 / 2007$ & 5 \\
\hline SW846-8260 & VOA & Tetrachloroethene & $\mathrm{QC}$ & 5 & $\mathrm{ug} / \mathrm{L}$ & $u$ & $5 / 22 / 2007$ & $6 / 5 / 2007$ & 5 \\
\hline SW846-8260 & VOA & Tetrachloroethene & $\mathrm{QC}$ & 5 & $\mathrm{ug} / \mathrm{L}$ & $\mathrm{u}$ & $5 / 23 / 2007$ & $6 / 5 / 2007$ & 5 \\
\hline SW846-8260 & VOA & Toluene & MW125 & 25 & $\mathrm{ug} / \mathrm{L}$ & $u$ & $5 / 21 / 2007$ & $6 / 1 / 2007$ & 25 \\
\hline SW846-8260 & VOA & Toluene & MW168 & 5 & $\mathrm{ug} / \mathrm{L}$ & $\mathrm{u}$ & $5 / 16 / 2007$ & $5 / 30 / 2007$ & 5 \\
\hline SW846-8260 & VOA & Toluene & MW185 & 120 & $\mathrm{ug} / \mathrm{L}$ & $u$ & $5 / 23 / 2007$ & 6/5/2007 & 120 \\
\hline SW846-8260 & VOA & Toluene & MW194 & 5 & $\mathrm{ug} / \mathrm{L}$ & $\mathrm{U}$ & $5 / 17 / 2007$ & $5 / 30 / 2007$ & 5 \\
\hline SW846-8260 & VOA & Toluene & MW197 & 5 & $\mathrm{ug} / \mathrm{L}$ & $\mathrm{U}$ & $5 / 21 / 2007$ & $6 / 1 / 2007$ & 5 \\
\hline SW846-8260 & VOA & Toluene & MW236 & 5 & $\mathrm{ug} / \mathrm{L}$ & $\mathrm{U}$ & $5 / 22 / 2007$ & $6 / 5 / 2007$ & 5 \\
\hline SW846-8260 & VOA & Toluene & MW236 & 5 & $\mathrm{ug} / \mathrm{L}$ & $\mathrm{U}$ & $5 / 22 / 2007$ & $6 / 5 / 2007$ & 5 \\
\hline SW846-8260 & VOA & Toluene & MW242 & 5 & $\mathrm{ug} / \mathrm{L}$ & u & $5 / 17 / 2007$ & $5 / 30 / 2007$ & 5 \\
\hline SW846-8260 & VOA & Toluene & MW243 & 5 & $\mathrm{ug} / \mathrm{L}$ & $\mathrm{U}$ & $5 / 15 / 2007$ & $5 / 29 / 2007$ & 5 \\
\hline SW846-8260 & VOA & Toluene & MW262 & 50 & ug/L & $u$ & $5 / 16 / 2007$ & $5 / 30 / 2007$ & 50 \\
\hline SW846-8260 & VOA & Toluene & MW340 & 250 & ug/L & $u$ & $5 / 23 / 2007$ & 6/5/2007 & 250 \\
\hline SW846-8260 & VOA & Toluene & MW381 & 5 & $\mathrm{ug} / \mathrm{L}$ & $u$ & $5 / 22 / 2007$ & $6 / 5 / 2007$ & 5 \\
\hline SW846-8260 & VOA & Toluene & MW66 & 100 & $\mathrm{ug} / \mathrm{L}$ & $U$ & $5 / 15 / 2007$ & $5 / 29 / 2007$ & 100 \\
\hline SW846-8260 & VOA & Toluene & $\mathrm{QC}$ & 5 & $\mathrm{ug} / \mathrm{L}$ & $U$ & $5 / 17 / 2007$ & $5 / 30 / 2007$ & 5 \\
\hline SW846-8260 & VOA & Toluene & $\mathrm{QC}$ & 5 & ug/L & $U$ & $5 / 21 / 2007$ & $6 / 1 / 2007$ & 5 \\
\hline SW846-8260 & VOA & Toluene & $\mathrm{QC}$ & 5 & $\mathrm{ug} / \mathrm{L}$ & U & $5 / 22 / 2007$ & $6 / 5 / 2007$ & 5 \\
\hline SW846-8260 & VOA & Toluene & $\mathrm{QC}$ & 5 & ug/L & U & $5 / 15 / 2007$ & $5 / 29 / 2007$ & 5 \\
\hline SW846-8260 & VOA & Toluene & QC & 5 & ug/L & U & $5 / 16 / 2007$ & $5 / 30 / 2007$ & 5 \\
\hline SW846-8260 & VOA & Toluene & $\mathrm{QC}$ & 5 & $\mathrm{ug} / \mathrm{L}$ & $u$ & $5 / 22 / 2007$ & 6/5/2007 & 5 \\
\hline SW846-8260 & VOA & Toluene & $\mathrm{QC}$ & 5 & $\mathrm{ug} / \mathrm{L}$ & $u$ & $5 / 22 / 2007$ & $6 / 5 / 2007$ & 5 \\
\hline SW846-8260 & VOA & Toluene & $\mathrm{QC}$ & 5 & $\mathrm{ug} / \mathrm{L}$ & U & $5 / 23 / 2007$ & $6 / 5 / 2007$ & 5 \\
\hline SW846-8260 & VOA & Total Xylene & MW125 & 75 & $\mathrm{ug} / \mathrm{L}$ & $u$ & $5 / 21 / 2007$ & $6 / 1 / 2007$ & 75 \\
\hline SW846-8260 & VOA & Total Xylene & MW168 & 15 & $\mathrm{ug} / \mathrm{L}$ & U & $5 / 16 / 2007$ & $5 / 30 / 2007$ & 15 \\
\hline SW846-8260 & VOA & Total Xylene & MW185 & 380 & ug/L & $u$ & $5 / 23 / 2007$ & 6/5/2007 & 380 \\
\hline SW846-8260 & VOA & Total Xylene & MW194 & 15 & ug/L & $U$ & $5 / 17 / 2007$ & $5 / 30 / 2007$ & 15 \\
\hline SW846-8260 & VOA & Total Xylene & MW197 & 15 & $\mathrm{ug} / \mathrm{L}$ & $u$ & $5 / 21 / 2007$ & $6 / 1 / 2007$ & 15 \\
\hline SW846-8260 & VOA & Total Xylene & MW236 & 15 & $\mathrm{ug} / \mathrm{L}$ & $u$ & $5 / 22 / 2007$ & $6 / 5 / 2007$ & 15 \\
\hline SW846-8260 & VOA & Total Xylene & MW236 & 15 & $\mathrm{ug} / \mathrm{L}$ & U & $5 / 22 / 2007$ & $6 / 5 / 2007$ & 15 \\
\hline SW846-8260 & VOA & Total Xylene & MW242 & 15 & ug/L & U & $5 / 17 / 2007$ & $5 / 30 / 2007$ & 15 \\
\hline SW846-8260 & VOA & Total Xylene & MW243 & 15 & $\mathrm{ug} / \mathrm{L}$ & U & $5 / 15 / 2007$ & $5 / 29 / 2007$ & 15 \\
\hline SW846-8260 & VOA & Total Xylene & MW262 & 150 & $\mathrm{ug} / \mathrm{L}$ & $u$ & $5 / 16 / 2007$ & $5 / 30 / 2007$ & 150 \\
\hline SW846-8260 & VOA & Total Xylene & MW340 & 750 & $\mathrm{ug} / \mathrm{L}$ & $U$ & $5 / 23 / 2007$ & $6 / 5 / 2007$ & 750 \\
\hline SW846-8260 & VOA & Total Xylene & MW381 & 15 & $\mathrm{ug} / \mathrm{L}$ & $\mathrm{U}$ & $5 / 22 / 2007$ & $6 / 5 / 2007$ & 15 \\
\hline SW846-8260 & VOA & Total Xylene & MW66 & 300 & $u g / L$ & $\mathrm{u}$ & $5 / 15 / 2007$ & $5 / 29 / 2007$ & 300 \\
\hline SW846-8260 & VOA & Total Xylene & $\mathrm{QC}$ & 15 & $\mathrm{ug} / \mathrm{L}$ & $\mathrm{U}$ & $5 / 17 / 2007$ & $5 / 30 / 2007$ & 15 \\
\hline SW846-8260 & VOA & Total Xylene & QC & 15 & $\mathrm{ug} / \mathrm{L}$ & $\mathrm{u}$ & $5 / 15 / 2007$ & $5 / 29 / 2007$ & 15 \\
\hline SW846-8260 & VOA & Total Xylene & $\mathrm{QC}$ & 15 & $\mathrm{ug} / \mathrm{L}$ & $\mathrm{U}$ & $5 / 21 / 2007$ & $6 / 1 / 2007$ & 15 \\
\hline SW846-8260 & VOA & Total Xylene & $\mathrm{QC}$ & 15 & $u g / L$ & $\mathrm{u}$ & $5 / 22 / 2007$ & $6 / 5 / 2007$ & 15 \\
\hline SW846-8260 & VOA & Total Xylene & $\mathrm{QC}$ & 15 & $u g / L$ & $\mathrm{u}$ & $5 / 16 / 2007$ & $5 / 30 / 2007$ & 15 \\
\hline SW846-8260 & VOA & Total Xylene & $\mathrm{QC}$ & 15 & $\mathrm{ug} / \mathrm{L}$ & $\mathrm{u}$ & $5 / 22 / 2007$ & $6 / 5 / 2007$ & 15 \\
\hline SW846-8260 & VOA & Total Xylene & $\mathrm{QC}$ & 15 & $\mathrm{ug} / \mathrm{L}$ & $\mathrm{u}$ & $5 / 22 / 2007$ & $6 / 5 / 2007$ & 15 \\
\hline SW846-8260 & VOA & Total Xylene & $\mathrm{QC}$ & 15 & $\mathrm{ug} / \mathrm{L}$ & $\mathrm{u}$ & $5 / 23 / 2007$ & $6 / 5 / 2007$ & 15 \\
\hline SW846-8260 & VOA & trans-1,2-Dichloroethene & MW125 & 25 & $u g / L$ & $\mathrm{u}$ & $5 / 21 / 2007$ & $6 / 1 / 2007$ & 25 \\
\hline SW846-8260 & VOA & trans-1,2-Dichloroethene & MW168 & 5 & $\mathrm{ug} / \mathrm{L}$ & $\mathrm{U}$ & $5 / 16 / 2007$ & $5 / 30 / 2007$ & 5 \\
\hline SW846-8260 & VOA & trans-1,2-Dichloroethene & MW185 & 120 & $u g / L$ & $\mathrm{u}$ & $5 / 23 / 2007$ & $6 / 5 / 2007$ & 120 \\
\hline SW846-8260 & VOA & trans-1,2-Dichloroethene & MW194 & 5 & $\mathrm{ug} / \mathrm{L}$ & $\mathrm{U}$ & $5 / 17 / 2007$ & $5 / 30 / 2007$ & 5 \\
\hline SW846-8260 & VOA & trans-1,2-Dichloroethene & MW197 & 5 & $\mathrm{ug} / \mathrm{L}$ & $\mathrm{u}$ & $5 / 21 / 2007$ & $6 / 1 / 2007$ & 5 \\
\hline SW846-8260 & VOA & trans-1,2-Dichloroethene & MW236 & 5 & $\mathrm{ug} / \mathrm{L}$ & $\mathrm{u}$ & $5 / 22 / 2007$ & $6 / 5 / 2007$ & 5 \\
\hline SW846-8260 & VOA & trans-1,2-Dichloroethene & MW236 & 5 & $\mathrm{ug} / \mathrm{L}$ & $\mathrm{u}$ & $5 / 22 / 2007$ & $6 / 5 / 2007$ & 5 \\
\hline SW846-8260 & VOA & trans-1,2-Dichloroethene & MW242 & 5 & $\mathrm{ug} / \mathrm{L}$ & $\mathrm{u}$ & $5 / 17 / 2007$ & $5 / 30 / 2007$ & 5 \\
\hline SW846-8260 & VOA & trans-1,2-Dichloroethene & MW243 & 5 & $u g / L$ & $\mathrm{u}$ & $5 / 15 / 2007$ & $5 / 29 / 2007$ & 5 \\
\hline SW846-8260 & VOA & trans-1,2-Dichloroethene & MW262 & 50 & $u g / L$ & $\mathrm{u}$ & $5 / 16 / 2007$ & $5 / 30 / 2007$ & 50 \\
\hline SW846-8260 & VOA & trans-1,2-Dichloroethene & MW340 & 250 & $u g / L$ & $\mathrm{U}$ & $5 / 23 / 2007$ & $6 / 5 / 2007$ & 250 \\
\hline SW846-8260 & VOA & trans-1,2-Dichloroethene & MW381 & 5 & $u g / L$ & $\mathrm{u}$ & $5 / 22 / 2007$ & $6 / 5 / 2007$ & 5 \\
\hline SW846-8260 & VOA & trans-1,2-Dichloroethene & MW66 & 100 & $u g / L$ & $\mathrm{u}$ & $5 / 15 / 2007$ & $5 / 29 / 2007$ & 100 \\
\hline SW846-8260 & VOA & trans-1,2-Dichloroethene & $\mathrm{QC}$ & 5 & $\mathrm{ug} / \mathrm{L}$ & $\mathrm{u}$ & $5 / 16 / 2007$ & $5 / 30 / 2007$ & 5 \\
\hline SW846-8260 & VOA & trans-1,2-Dichloroethene & $\mathrm{QC}$ & 5 & $\mathrm{ug} / \mathrm{L}$ & $\mathrm{u}$ & $5 / 17 / 2007$ & $5 / 30 / 2007$ & 5 \\
\hline SW846-8260 & VOA & trans-1,2-Dichloroethene & $\mathrm{QC}$ & 5 & $\mathrm{ug} / \mathrm{L}$ & $u$ & $5 / 21 / 2007$ & $6 / 1 / 2007$ & 5 \\
\hline SW846-8260 & VOA & trans-1,2-Dichloroethene & $\mathrm{QC}$ & 5 & $u g / L$ & $\mathrm{u}$ & $5 / 15 / 2007$ & $5 / 29 / 2007$ & 5 \\
\hline SW846-8260 & VOA & trans-1,2-Dichloroethene & $\mathrm{QC}$ & 5 & $\mathrm{ug} / \mathrm{L}$ & $\mathrm{U}$ & $5 / 22 / 2007$ & $6 / 5 / 2007$ & 5 \\
\hline SW846-8260 & VOA & trans-1,2-Dichloroethene & QC & 5 & $u g / L$ & $\mathrm{u}$ & $5 / 22 / 2007$ & $6 / 5 / 2007$ & 5 \\
\hline SW846-8260 & VOA & trans-1,2-Dichloroethene & $\mathrm{QC}$ & 5 & $u g / L$ & $\mathrm{u}$ & $5 / 22 / 2007$ & $6 / 5 / 2007$ & 5 \\
\hline SW846-8260 & VOA & trans-1,2-Dichloroethene & $\mathrm{QC}$ & 5 & $\mathrm{ug} / \mathrm{L}$ & $u$ & $5 / 23 / 2007$ & $6 / 5 / 2007$ & 5 \\
\hline SW846-8260 & VOA & trans-1,3-Dichloropropene & MW125 & 25 & $u g / L$ & $\mathrm{u}$ & $5 / 21 / 2007$ & $6 / 1 / 2007$ & 25 \\
\hline SW846-8260 & VOA & trans-1,3-Dichloropropene & MW168 & 5 & $u g / L$ & $\mathrm{u}$ & $5 / 16 / 2007$ & $5 / 30 / 2007$ & 5 \\
\hline SW846-8260 & VOA & trans-1,3-Dichloropropene & MW185 & 120 & $u g / L$ & $\mathrm{u}$ & $5 / 23 / 2007$ & $6 / 5 / 2007$ & 120 \\
\hline
\end{tabular}




\begin{tabular}{|c|c|c|c|c|c|c|c|c|c|}
\hline Method & AnaType & Chemical Name & Station & Results & Units & $\begin{array}{l}\text { Result } \\
\text { Qualifier }\end{array}$ & Date Collected & $\begin{array}{c}\text { Date } \\
\text { Analyzed }\end{array}$ & $\begin{array}{l}\text { Detection } \\
\text { Limit }\end{array}$ \\
\hline SW846-8260 & VOA & trans-1,3-Dichloropropene & MW194 & 5 & $u g / L$ & u & $5 / 17 / 2007$ & $5 / 30 / 2007$ & 5 \\
\hline SW846-8260 & VOA & trans-1,3-Dichloropropene & MW197 & 5 & $\mathrm{ug} / \mathrm{L}$ & $\mathrm{u}$ & $5 / 21 / 2007$ & $6 / 1 / 2007$ & 5 \\
\hline SW846-8260 & VOA & trans-1,3-Dichloropropene & MW236 & 5 & $\mathrm{ug} / \mathrm{L}$ & $\mathrm{u}$ & $5 / 22 / 2007$ & $6 / 5 / 2007$ & 5 \\
\hline SW846-8260 & VOA & trans-1,3-Dichloropropene & MW236 & 5 & $\mathrm{ug} / \mathrm{L}$ & $\mathrm{u}$ & $5 / 22 / 2007$ & $6 / 5 / 2007$ & 5 \\
\hline SW846-8260 & VOA & trans-1,3-Dichloropropene & MW242 & 5 & $\mathrm{ug} / \mathrm{L}$ & $\mathrm{u}$ & $5 / 17 / 2007$ & $5 / 30 / 2007$ & 5 \\
\hline SW846-8260 & VOA & trans-1,3-Dichloropropene & MW243 & 5 & $\mathrm{ug} / \mathrm{L}$ & $\mathrm{u}$ & $5 / 15 / 2007$ & $5 / 29 / 2007$ & 5 \\
\hline SW846-8260 & VOA & trans-1,3-Dichloropropene & MW262 & 50 & $u g / L$ & $\mathrm{u}$ & $5 / 16 / 2007$ & $5 / 30 / 2007$ & 50 \\
\hline SW846-8260 & VOA & trans-1,3-Dichloropropene & MW340 & 250 & $\mathrm{ug} / \mathrm{L}$ & $\mathrm{u}$ & $5 / 23 / 2007$ & $6 / 5 / 2007$ & 250 \\
\hline SW846-8260 & VOA & trans-1,3-Dichloropropene & MW381 & 5 & $\mathrm{ug} / \mathrm{L}$ & $\mathrm{u}$ & $5 / 22 / 2007$ & $6 / 5 / 2007$ & 5 \\
\hline SW846-8260 & VOA & trans-1,3-Dichloropropene & MW66 & 100 & $\mathrm{ug} / \mathrm{L}$ & $\mathrm{u}$ & $5 / 15 / 2007$ & $5 / 29 / 2007$ & 100 \\
\hline SW846-8260 & VOA & trans-1,3-Dichloropropene & $\mathrm{QC}$ & 5 & $\mathrm{ug} / \mathrm{L}$ & $\mathrm{u}$ & $5 / 16 / 2007$ & $5 / 30 / 2007$ & 5 \\
\hline SW846-8260 & VOA & trans-1,3-Dichloropropene & $\mathrm{QC}$ & 5 & $\mathrm{ug} / \mathrm{L}$ & $\mathrm{u}$ & $5 / 17 / 2007$ & $5 / 30 / 2007$ & 5 \\
\hline SW846-8260 & VOA & trans-1,3-Dichloropropene & QC & 5 & $\mathrm{ug} / \mathrm{L}$ & $\mathrm{u}$ & $5 / 21 / 2007$ & 6/1/2007 & 5 \\
\hline SW846-8260 & VOA & trans-1,3-Dichloropropene & $\mathrm{QC}$ & 5 & $\mathrm{ug} / \mathrm{L}$ & $\mathrm{u}$ & $5 / 15 / 2007$ & $5 / 29 / 2007$ & 5 \\
\hline SW846-8260 & VOA & trans-1,3-Dichloropropene & $\mathrm{QC}$ & 5 & ug/L & $\mathrm{u}$ & $5 / 22 / 2007$ & $6 / 5 / 2007$ & 5 \\
\hline SW846-8260 & VOA & trans-1,3-Dichloropropene & $\mathrm{QC}$ & 5 & $\mathrm{ug} / \mathrm{L}$ & $\mathrm{u}$ & $5 / 22 / 2007$ & $6 / 5 / 2007$ & 5 \\
\hline SW846-8260 & VOA & trans-1,3-Dichloropropene & $\mathrm{QC}$ & 5 & $\mathrm{ug} / \mathrm{L}$ & $\mathrm{u}$ & $5 / 22 / 2007$ & $6 / 5 / 2007$ & 5 \\
\hline SW846-8260 & VOA & trans-1,3-Dichloropropene & $\mathrm{QC}$ & 5 & $\mathrm{ug} / \mathrm{L}$ & $\mathrm{u}$ & $5 / 23 / 2007$ & $6 / 5 / 2007$ & 5 \\
\hline sW846-8260 & VOA & Trichloroethene & MW125 & 700 & $\mathrm{ug} / \mathrm{L}$ & $\mathrm{D}$ & $5 / 21 / 2007$ & $6 / 1 / 2007$ & 5 \\
\hline SW846-8260 & VOA & Trichloroethene & MW168 & 110 & $\mathrm{ug} / \mathrm{L}$ & & $5 / 16 / 2007$ & $5 / 30 / 2007$ & 1 \\
\hline SW846-8260 & VOA & Trichloroethene & MW185 & 3300 & $\mathrm{ug} / \mathrm{L}$ & D & $5 / 23 / 2007$ & $6 / 5 / 2007$ & 25 \\
\hline SW846-8260 & VOA & Trichloroethene & MW194 & 1 & $\mathrm{ug} / \mathrm{L}$ & $\mathrm{u}$ & $5 / 17 / 2007$ & $5 / 30 / 2007$ & 1 \\
\hline SW846-8260 & VOA & Trichloroethene & MW197 & 3.9 & $\mathrm{ug} / \mathrm{L}$ & & $5 / 21 / 2007$ & $6 / 1 / 2007$ & 1 \\
\hline SW846-8260 & VOA & Trichloroethene & MW236 & 21 & $\mathrm{ug} / \mathrm{L}$ & & $5 / 22 / 2007$ & $6 / 5 / 2007$ & 1 \\
\hline SW846-8260 & VOA & Trichloroethene & MW236 & 22 & $\mathrm{ug} / \mathrm{L}$ & & $5 / 22 / 2007$ & $6 / 5 / 2007$ & 1 \\
\hline SW846-8260 & VOA & Trichloroethene & MW242 & 110 & $\mathrm{ug} / \mathrm{L}$ & & $5 / 17 / 2007$ & $5 / 30 / 2007$ & 1 \\
\hline SW846-8260 & VOA & Trichloroethene & MW243 & 100 & $\mathrm{ug} / \mathrm{L}$ & & $5 / 15 / 2007$ & $5 / 29 / 2007$ & 1 \\
\hline SW846-8260 & VOA & Trichloroethene & MW262 & 950 & $\mathrm{ug} / \mathrm{L}$ & D & $5 / 16 / 2007$ & $5 / 30 / 2007$ & 10 \\
\hline SW846-8260 & VOA & Trichloroethene & MW340 & 6500 & $\mathrm{ug} / \mathrm{L}$ & D & $5 / 23 / 2007$ & $6 / 5 / 2007$ & 50 \\
\hline SW846-8260 & VOA & Trichloroethene & MW381 & 50 & $\mathrm{ug} / \mathrm{L}$ & & $5 / 22 / 2007$ & 6/5/2007 & 1 \\
\hline SW846-8260 & VOA & Trichloroethene & MW66 & 700 & $\mathrm{ug} / \mathrm{L}$ & D & $5 / 15 / 2007$ & $5 / 29 / 2007$ & 20 \\
\hline SW846-8260 & VOA & Trichloroethene & $\mathrm{QC}$ & 1 & $\mathrm{ug} / \mathrm{L}$ & $\mathrm{U}$ & $5 / 17 / 2007$ & $5 / 30 / 2007$ & 1 \\
\hline SW846-8260 & VOA & Trichloroethene & $\mathrm{QC}$ & 1 & $\mathrm{ug} / \mathrm{L}$ & $\mathrm{U}$ & $5 / 21 / 2007$ & 6/1/2007 & 1 \\
\hline SW846-8260 & VOA & Trichloroethene & $\mathrm{QC}$ & 1 & $\mathrm{ug} / \mathrm{L}$ & $\mathrm{u}$ & $5 / 22 / 2007$ & $6 / 5 / 2007$ & 1 \\
\hline SW846-8260 & VOA & Trichloroethene & $\mathrm{QC}$ & 1 & $\mathrm{ug} / \mathrm{L}$ & $u$ & $5 / 15 / 2007$ & $5 / 29 / 2007$ & 1 \\
\hline SW846-8260 & VOA & Trichloroethene & $\mathrm{QC}$ & 1 & $\mathrm{ug} / \mathrm{L}$ & $\mathrm{u}$ & $5 / 16 / 2007$ & $5 / 30 / 2007$ & 1 \\
\hline SW846-8260 & VOA & Trichloroethene & $\mathrm{QC}$ & 1 & $\mathrm{ug} / \mathrm{L}$ & u & $5 / 22 / 2007$ & $6 / 5 / 2007$ & 1 \\
\hline SW846-8260 & VOA & Trichloroethene & $\mathrm{QC}$ & 1 & $\mathrm{ug} / \mathrm{L}$ & $u$ & $5 / 22 / 2007$ & $6 / 5 / 2007$ & 1 \\
\hline SW846-8260 & VOA & Trichloroethene & QC & 1.7 & $\mathrm{ug} / \mathrm{L}$ & & $5 / 23 / 2007$ & $6 / 5 / 2007$ & 1 \\
\hline SW846-8260 & VOA & Vinyl acetate & MW125 & 50 & $\mathrm{ug} / \mathrm{L}$ & $U$ & $5 / 21 / 2007$ & 6/1/2007 & 50 \\
\hline SW846-8260 & VOA & Vinyl acetate & MW168 & 10 & $\mathrm{ug} / \mathrm{L}$ & $\mathrm{JU}$ & $5 / 16 / 2007$ & $5 / 30 / 2007$ & 10 \\
\hline SW846-8260 & VOA & Vinyl acetate & MW185 & 250 & $\mathrm{ug} / \mathrm{L}$ & $U$ & $5 / 23 / 2007$ & $6 / 5 / 2007$ & 250 \\
\hline SW846-8260 & VOA & Vinyl acetate & MW194 & 10 & $\mathrm{ug} / \mathrm{L}$ & $\mathrm{JU}$ & $5 / 17 / 2007$ & $5 / 30 / 2007$ & 10 \\
\hline SW846-8260 & VOA & Vinyl acetate & MW197 & 10 & $\mathrm{ug} / \mathrm{L}$ & $\mathrm{U}$ & $5 / 21 / 2007$ & 6/1/2007 & 10 \\
\hline SW846-8260 & VOA & Vinyl acetate & MW236 & 10 & $\mathrm{ug} / \mathrm{L}$ & $u$ & $5 / 22 / 2007$ & $6 / 5 / 2007$ & 10 \\
\hline SW846-8260 & VOA & Vinyl acetate & MW236 & 10 & $\mathrm{ug} / \mathrm{L}$ & U & $5 / 22 / 2007$ & 6/5/2007 & 10 \\
\hline SW846-8260 & VOA & Vinyl acetate & MW242 & 10 & $\mathrm{ug} / \mathrm{L}$ & $\mathrm{JU}$ & $5 / 17 / 2007$ & $5 / 30 / 2007$ & 10 \\
\hline SW846-8260 & VOA & Vinyl acetate & MW243 & 10 & $\mathrm{ug} / \mathrm{L}$ & U & $5 / 15 / 2007$ & $5 / 29 / 2007$ & 10 \\
\hline SW846-8260 & VOA & Vinyl acetate & MW262 & 100 & $\mathrm{ug} / \mathrm{L}$ & $\mathrm{JU}$ & $5 / 16 / 2007$ & $5 / 30 / 2007$ & 100 \\
\hline SW846-8260 & VOA & Vinyl acetate & MW340 & 500 & $\mathrm{ug} / \mathrm{L}$ & $\mathrm{u}$ & $5 / 23 / 2007$ & 6/5/2007 & 500 \\
\hline SW846-8260 & VOA & Vinyl acetate & MW381 & 10 & $\mathrm{ug} / \mathrm{L}$ & $\mathrm{U}$ & $5 / 22 / 2007$ & 6/5/2007 & 10 \\
\hline SW846-8260 & VOA & Vinyl acetate & MW66 & 200 & $\mathrm{ug} / \mathrm{L}$ & U & $5 / 15 / 2007$ & $5 / 29 / 2007$ & 200 \\
\hline SW846-8260 & VOA & Vinyl acetate & $\mathrm{QC}$ & 10 & $\mathrm{ug} / \mathrm{L}$ & JU & $5 / 17 / 2007$ & $5 / 30 / 2007$ & 10 \\
\hline SW846-8260 & VOA & Vinyl acetate & $\mathrm{QC}$ & 10 & $\mathrm{ug} / \mathrm{L}$ & $\mathrm{U}$ & $5 / 21 / 2007$ & $6 / 1 / 2007$ & 10 \\
\hline SW846-8260 & VOA & Vinyl acetate & QC & 10 & $\mathrm{ug} / \mathrm{L}$ & U & $5 / 22 / 2007$ & $6 / 5 / 2007$ & 10 \\
\hline SW846-8260 & VOA & Vinyl acetate & $\mathrm{QC}$ & 10 & $\mathrm{ug} / \mathrm{L}$ & $U$ & $5 / 15 / 2007$ & $5 / 29 / 2007$ & 10 \\
\hline SW846-8260 & VOA & Vinyl acetate & $\mathrm{QC}$ & 10 & $\mathrm{ug} / \mathrm{L}$ & JU & $5 / 16 / 2007$ & $5 / 30 / 2007$ & 10 \\
\hline SW846-8260 & VOA & Vinyl acetate & $\mathrm{QC}$ & 10 & $\mathrm{ug} / \mathrm{L}$ & $\mathrm{U}$ & $5 / 22 / 2007$ & 6/5/2007 & 10 \\
\hline SW846-8260 & VOA & Vinyl acetate & $\mathrm{QC}$ & 10 & $\mathrm{ug} / \mathrm{L}$ & U & $5 / 22 / 2007$ & 6/5/2007 & 10 \\
\hline SW846-8260 & VOA & Vinyl acetate & QC & 10 & $\mathrm{ug} / \mathrm{L}$ & $\mathrm{U}$ & $5 / 23 / 2007$ & $6 / 5 / 2007$ & 10 \\
\hline SW846-8260 & VOA & Vinyl chloride & MW125 & 10 & $\mathrm{ug} / \mathrm{L}$ & $u$ & $5 / 21 / 2007$ & 6/1/2007 & 10 \\
\hline SW846-8260 & VOA & Vinyl chloride & MW168 & 2 & $\mathrm{ug} / \mathrm{L}$ & $u$ & $5 / 16 / 2007$ & $5 / 30 / 2007$ & 2 \\
\hline SW846-8260 & VOA & Vinyl chloride & MW185 & 50 & $\mathrm{ug} / \mathrm{L}$ & $\mathrm{U}$ & $5 / 23 / 2007$ & 6/5/2007 & 50 \\
\hline SW846-8260 & VOA & Vinyl chloride & MW194 & 2 & $\mathrm{ug} / \mathrm{L}$ & $u$ & $5 / 17 / 2007$ & $5 / 30 / 2007$ & 2 \\
\hline SW846-8260 & VOA & Vinyl chloride & MW197 & 2 & $\mathrm{ug} / \mathrm{L}$ & $u$ & $5 / 21 / 2007$ & $6 / 1 / 2007$ & 2 \\
\hline SW846-8260 & VOA & Vinyl chloride & MW236 & 2 & $\mathrm{ug} / \mathrm{L}$ & $u$ & $5 / 22 / 2007$ & $6 / 5 / 2007$ & 2 \\
\hline SW846-8260 & VOA & Vinyl chloride & MW236 & 2 & ug/L & $u$ & $5 / 22 / 2007$ & 6/5/2007 & 2 \\
\hline SW846-8260 & VOA & Vinyl chloride & MW242 & 2 & ug/L & 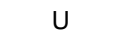 & $5 / 17 / 2007$ & $5 / 30 / 2007$ & 2 \\
\hline SW846-8260 & VOA & Vinyl chloride & MW243 & 2 & $\mathrm{ug} / \mathrm{L}$ & $\mathrm{U}$ & $5 / 15 / 2007$ & $5 / 29 / 2007$ & 2 \\
\hline
\end{tabular}




\begin{tabular}{|c|c|c|c|c|c|c|c|c|c|}
\hline Method & AnaType & Chemical Name & Station & Results & Units & $\begin{array}{c}\text { Result } \\
\text { Qualifier }\end{array}$ & Date Collected & $\begin{array}{c}\text { Date } \\
\text { Analyzed }\end{array}$ & $\begin{array}{l}\text { Detection } \\
\text { Limit }\end{array}$ \\
\hline SW846-8260 & VOA & Vinyl chloride & MW262 & 20 & $u g / L$ & U & $5 / 16 / 2007$ & $5 / 30 / 2007$ & 20 \\
\hline SW846-8260 & VOA & Vinyl chloride & MW340 & 100 & $\mathrm{ug} / \mathrm{L}$ & $u$ & $5 / 23 / 2007$ & $6 / 5 / 2007$ & 100 \\
\hline SW846-8260 & VOA & Vinyl chloride & MW381 & 2 & $\mathrm{ug} / \mathrm{L}$ & u & $5 / 22 / 2007$ & $6 / 5 / 2007$ & 2 \\
\hline SW846-8260 & VOA & Vinyl chloride & MW66 & 40 & $\mathrm{ug} / \mathrm{L}$ & $u$ & $5 / 15 / 2007$ & $5 / 29 / 2007$ & 40 \\
\hline SW846-8260 & VOA & Vinyl chloride & QC & 2 & $\mathrm{ug} / \mathrm{L}$ & u & $5 / 17 / 2007$ & $5 / 30 / 2007$ & 2 \\
\hline SW846-8260 & VOA & Vinyl chloride & $\mathrm{QC}$ & 2 & $\mathrm{ug} / \mathrm{L}$ & $\mathrm{U}$ & $5 / 21 / 2007$ & $6 / 1 / 2007$ & 2 \\
\hline SW846-8260 & VOA & Vinyl chloride & QC & 2 & $\mathrm{ug} / \mathrm{L}$ & $\mathrm{U}$ & $5 / 22 / 2007$ & $6 / 5 / 2007$ & 2 \\
\hline SW846-8260 & VOA & Vinyl chloride & $\mathrm{QC}$ & 2 & $\mathrm{ug} / \mathrm{L}$ & $\mathrm{U}$ & $5 / 15 / 2007$ & $5 / 29 / 2007$ & 2 \\
\hline SW846-8260 & VOA & Vinyl chloride & $\mathrm{QC}$ & 2 & $\mathrm{ug} / \mathrm{L}$ & $u$ & $5 / 16 / 2007$ & $5 / 30 / 2007$ & 2 \\
\hline SW846-8260 & VOA & Vinyl chloride & $\mathrm{QC}$ & 2 & $\mathrm{ug} / \mathrm{L}$ & $\mathrm{u}$ & $5 / 22 / 2007$ & $6 / 5 / 2007$ & 2 \\
\hline SW846-8260 & VOA & Vinyl chloride & $\mathrm{QC}$ & 2 & $\mathrm{ug} / \mathrm{L}$ & $\mathrm{U}$ & $5 / 22 / 2007$ & $6 / 5 / 2007$ & 2 \\
\hline SW846-8260 & VOA & Vinyl chloride & $\mathrm{QC}$ & 2 & $\mathrm{ug} / \mathrm{L}$ & $u$ & $5 / 23 / 2007$ & $6 / 5 / 2007$ & 2 \\
\hline EPA-310.1 & WETCHEM & Alkalinity & MW125 & 91 & $\mathrm{mg} / \mathrm{L}$ & & $5 / 21 / 2007$ & $5 / 24 / 2007$ & 10 \\
\hline EPA-310.1 & WETCHEM & Alkalinity & MW168 & 77 & $\mathrm{mg} / \mathrm{L}$ & & $5 / 16 / 2007$ & $5 / 24 / 2007$ & 10 \\
\hline EPA-310.1 & WETCHEM & Alkalinity & MW185 & 109 & $\mathrm{mg} / \mathrm{L}$ & & $5 / 23 / 2007$ & $5 / 24 / 2007$ & 10 \\
\hline EPA-310.1 & WETCHEM & Alkalinity & MW194 & 72 & $\mathrm{mg} / \mathrm{L}$ & & $5 / 17 / 2007$ & $5 / 24 / 2007$ & 10 \\
\hline EPA-310.1 & WETCHEM & Alkalinity & MW197 & 78 & $\mathrm{mg} / \mathrm{L}$ & & $5 / 21 / 2007$ & $5 / 24 / 2007$ & 10 \\
\hline EPA-310.1 & WETCHEM & Alkalinity & MW236 & 88 & $\mathrm{mg} / \mathrm{L}$ & & $5 / 22 / 2007$ & $5 / 24 / 2007$ & 10 \\
\hline EPA-310.1 & WETCHEM & Alkalinity & MW236 & 92 & $\mathrm{mg} / \mathrm{L}$ & & $5 / 22 / 2007$ & $5 / 24 / 2007$ & 10 \\
\hline EPA-310.1 & WETCHEM & Alkalinity & MW242 & 55 & $\mathrm{mg} / \mathrm{L}$ & & $5 / 17 / 2007$ & $5 / 30 / 2007$ & 10 \\
\hline EPA-310.1 & WETCHEM & Alkalinity & MW243 & 113 & $\mathrm{mg} / \mathrm{L}$ & & $5 / 15 / 2007$ & $5 / 24 / 2007$ & 10 \\
\hline EPA-310.1 & WETCHEM & Alkalinity & MW262 & 105 & $\mathrm{mg} / \mathrm{L}$ & & $5 / 16 / 2007$ & $5 / 24 / 2007$ & 10 \\
\hline EPA-310.1 & WETCHEM & Alkalinity & MW340 & 109 & $\mathrm{mg} / \mathrm{L}$ & & $5 / 23 / 2007$ & $5 / 24 / 2007$ & 10 \\
\hline EPA-310.1 & WETCHEM & Alkalinity & MW381 & 98 & $\mathrm{mg} / \mathrm{L}$ & & $5 / 22 / 2007$ & $5 / 24 / 2007$ & 10 \\
\hline EPA-310.1 & WETCHEM & Alkalinity & MW66 & 72 & $\mathrm{mg} / \mathrm{L}$ & & $5 / 15 / 2007$ & $5 / 24 / 2007$ & 10 \\
\hline EPA-310.1 & WETCHEM & Alkalinity & $\mathrm{QC}$ & 10 & $\mathrm{mg} / \mathrm{L}$ & $\mathrm{U}$ & $5 / 22 / 2007$ & $5 / 24 / 2007$ & 10 \\
\hline EPA-310.1 & WETCHEM & Alkalinity & QC & 10 & $\mathrm{mg} / \mathrm{L}$ & $\mathrm{u}$ & $5 / 22 / 2007$ & $5 / 24 / 2007$ & 10 \\
\hline SM-2320 B 17 & WETCHEM & Bicarbonate as $\mathrm{CaCO} 3$ & MW125 & 91 & $\mathrm{mg} / \mathrm{L}$ & & $5 / 21 / 2007$ & $5 / 29 / 2007$ & 10 \\
\hline SM-2320 B 17 & WETCHEM & Bicarbonate as $\mathrm{CaCO} 3$ & MW168 & 77 & $\mathrm{mg} / \mathrm{L}$ & & $5 / 16 / 2007$ & $5 / 29 / 2007$ & 10 \\
\hline SM-2320 B 17 & WETCHEM & Bicarbonate as $\mathrm{CaCO} 3$ & MW185 & 109 & $\mathrm{mg} / \mathrm{L}$ & & $5 / 23 / 2007$ & $5 / 29 / 2007$ & 10 \\
\hline SM-2320 B 17 & WETCHEM & Bicarbonate as $\mathrm{CaCO} 3$ & MW194 & 72 & $\mathrm{mg} / \mathrm{L}$ & & $5 / 17 / 2007$ & $5 / 29 / 2007$ & 10 \\
\hline SM-2320 B 17 & WETCHEM & Bicarbonate as $\mathrm{CaCO} 3$ & MW197 & 78 & $\mathrm{mg} / \mathrm{L}$ & & $5 / 21 / 2007$ & $5 / 29 / 2007$ & 10 \\
\hline SM-2320 B 17 & WETCHEM & Bicarbonate as $\mathrm{CaCO} 3$ & MW236 & 88 & $\mathrm{mg} / \mathrm{L}$ & & $5 / 22 / 2007$ & $5 / 29 / 2007$ & 10 \\
\hline SM-2320 B 17 & WETCHEM & Bicarbonate as $\mathrm{CaCO} 3$ & MW236 & 92 & $\mathrm{mg} / \mathrm{L}$ & & $5 / 22 / 2007$ & $5 / 29 / 2007$ & 10 \\
\hline SM-2320 B 17 & WETCHEM & Bicarbonate as $\mathrm{CaCO} 3$ & MW242 & 55 & $\mathrm{mg} / \mathrm{L}$ & & $5 / 17 / 2007$ & $5 / 29 / 2007$ & 10 \\
\hline SM-2320 B 17 & WETCHEM & Bicarbonate as $\mathrm{CaCO} 3$ & MW243 & 113 & $\mathrm{mg} / \mathrm{L}$ & & $5 / 15 / 2007$ & $5 / 29 / 2007$ & 10 \\
\hline SM-2320 B 17 & WETCHEM & Bicarbonate as $\mathrm{CaCO} 3$ & MW262 & 105 & $\mathrm{mg} / \mathrm{L}$ & & $5 / 16 / 2007$ & $5 / 29 / 2007$ & 10 \\
\hline SM-2320 B 17 & WETCHEM & Bicarbonate as $\mathrm{CaCO} 3$ & MW340 & 109 & $\mathrm{mg} / \mathrm{L}$ & & $5 / 23 / 2007$ & $5 / 29 / 2007$ & 10 \\
\hline SM-2320 B 17 & WETCHEM & Bicarbonate as $\mathrm{CaCO} 3$ & MW381 & 98 & $\mathrm{mg} / \mathrm{L}$ & & $5 / 22 / 2007$ & $5 / 29 / 2007$ & 10 \\
\hline SM-2320 B 17 & WETCHEM & Bicarbonate as $\mathrm{CaCO} 3$ & MW66 & 72 & $\mathrm{mg} / \mathrm{L}$ & & $5 / 15 / 2007$ & $5 / 29 / 2007$ & 10 \\
\hline SM-2320 B 17 & WETCHEM & Bicarbonate as $\mathrm{CaCO} 3$ & QC & 10 & $\mathrm{mg} / \mathrm{L}$ & $\mathrm{u}$ & $5 / 22 / 2007$ & $5 / 29 / 2007$ & 10 \\
\hline SM-2320 B 17 & WETCHEM & Bicarbonate as $\mathrm{CaCO} 3$ & QC & 10 & $\mathrm{mg} / \mathrm{L}$ & $u$ & $5 / 22 / 2007$ & $5 / 29 / 2007$ & 10 \\
\hline SM-2320 B 17 & WETCHEM & Carbonate as $\mathrm{CaCO} 3$ & MW125 & 10 & $\mathrm{mg} / \mathrm{L}$ & $\mathrm{u}$ & $5 / 21 / 2007$ & $5 / 29 / 2007$ & 10 \\
\hline SM-2320 B 17 & WETCHEM & Carbonate as $\mathrm{CaCO} 3$ & MW168 & 10 & $\mathrm{mg} / \mathrm{L}$ & $u$ & $5 / 16 / 2007$ & $5 / 29 / 2007$ & 10 \\
\hline SM-2320 B 17 & WETCHEM & Carbonate as $\mathrm{CaCO} 3$ & MW185 & 10 & $\mathrm{mg} / \mathrm{L}$ & $\mathrm{u}$ & $5 / 23 / 2007$ & $5 / 29 / 2007$ & 10 \\
\hline SM-2320 B 17 & WETCHEM & Carbonate as $\mathrm{CaCO} 3$ & MW194 & 10 & $\mathrm{mg} / \mathrm{L}$ & $\mathrm{u}$ & $5 / 17 / 2007$ & $5 / 29 / 2007$ & 10 \\
\hline SM-2320 B 17 & WETCHEM & Carbonate as $\mathrm{CaCO} 3$ & MW197 & 10 & $\mathrm{mg} / \mathrm{L}$ & $u$ & $5 / 21 / 2007$ & $5 / 29 / 2007$ & 10 \\
\hline SM-2320 B 17 & WETCHEM & Carbonate as $\mathrm{CaCO} 3$ & MW236 & 10 & $\mathrm{mg} / \mathrm{L}$ & $\mathrm{u}$ & $5 / 22 / 2007$ & $5 / 29 / 2007$ & 10 \\
\hline SM-2320 B 17 & WETCHEM & Carbonate as $\mathrm{CaCO} 3$ & MW236 & 10 & $\mathrm{mg} / \mathrm{L}$ & $\mathrm{U}$ & $5 / 22 / 2007$ & $5 / 29 / 2007$ & 10 \\
\hline SM-2320 B 17 & WETCHEM & Carbonate as $\mathrm{CaCO} 3$ & MW242 & 10 & $\mathrm{mg} / \mathrm{L}$ & $\mathrm{u}$ & $5 / 17 / 2007$ & $5 / 29 / 2007$ & 10 \\
\hline SM-2320 B 17 & WETCHEM & Carbonate as $\mathrm{CaCO} 3$ & MW243 & 10 & $\mathrm{mg} / \mathrm{L}$ & $u$ & $5 / 15 / 2007$ & $5 / 29 / 2007$ & 10 \\
\hline SM-2320 B 17 & WETCHEM & Carbonate as $\mathrm{CaCO} 3$ & MW262 & 10 & $\mathrm{mg} / \mathrm{L}$ & $\mathrm{u}$ & $5 / 16 / 2007$ & $5 / 29 / 2007$ & 10 \\
\hline SM-2320 B 17 & WETCHEM & Carbonate as $\mathrm{CaCO} 3$ & MW340 & 10 & $\mathrm{mg} / \mathrm{L}$ & $u$ & $5 / 23 / 2007$ & $5 / 29 / 2007$ & 10 \\
\hline SM-2320 B 17 & WETCHEM & Carbonate as $\mathrm{CaCO} 3$ & MW381 & 10 & $\mathrm{mg} / \mathrm{L}$ & $u$ & $5 / 22 / 2007$ & $5 / 29 / 2007$ & 10 \\
\hline SM-2320 B 17 & WETCHEM & Carbonate as $\mathrm{CaCO} 3$ & MW66 & 10 & $\mathrm{mg} / \mathrm{L}$ & $\mathrm{u}$ & $5 / 15 / 2007$ & $5 / 29 / 2007$ & 10 \\
\hline SM-2320 B 17 & WETCHEM & Carbonate as $\mathrm{CaCO} 3$ & $\mathrm{QC}$ & 10 & $\mathrm{mg} / \mathrm{L}$ & $u$ & $5 / 22 / 2007$ & $5 / 29 / 2007$ & 10 \\
\hline SM-2320 B 17 & WETCHEM & Carbonate as $\mathrm{CaCO} 3$ & $\mathrm{QC}$ & 10 & $\mathrm{mg} / \mathrm{L}$ & $\mathrm{u}$ & $5 / 22 / 2007$ & $5 / 29 / 2007$ & 10 \\
\hline SW846-9060 & WETCHEM & Dissolved Organic Carbon & MW125 & 1 & $\mathrm{mg} / \mathrm{L}$ & $\mathrm{U}$ & $5 / 21 / 2007$ & $6 / 4 / 2007$ & 1 \\
\hline SW846-9060 & WETCHEM & Dissolved Organic Carbon & MW168 & 8.2 & $\mathrm{mg} / \mathrm{L}$ & & $5 / 16 / 2007$ & $6 / 1 / 2007$ & 1 \\
\hline SW846-9060 & WETCHEM & Dissolved Organic Carbon & MW185 & 1 & $\mathrm{mg} / \mathrm{L}$ & $\mathrm{u}$ & $5 / 23 / 2007$ & $6 / 5 / 2007$ & 1 \\
\hline SW846-9060 & WETCHEM & Dissolved Organic Carbon & MW194 & 1 & $\mathrm{mg} / \mathrm{L}$ & $u$ & $5 / 17 / 2007$ & $6 / 4 / 2007$ & 1 \\
\hline SW846-9060 & WETCHEM & Dissolved Organic Carbon & MW197 & 2 & $\mathrm{mg} / \mathrm{L}$ & & $5 / 21 / 2007$ & $6 / 4 / 2007$ & 1 \\
\hline SW846-9060 & WETCHEM & Dissolved Organic Carbon & MW236 & 1 & $\mathrm{mg} / \mathrm{L}$ & $\mathrm{U}$ & $5 / 22 / 2007$ & $6 / 5 / 2007$ & 1 \\
\hline SW846-9060 & WETCHEM & Dissolved Organic Carbon & MW236 & 1 & $\mathrm{mg} / \mathrm{L}$ & $\mathrm{u}$ & $5 / 22 / 2007$ & $6 / 5 / 2007$ & 1 \\
\hline SW846-9060 & WETCHEM & Dissolved Organic Carbon & MW242 & 1 & $\mathrm{mg} / \mathrm{L}$ & $\mathrm{u}$ & $5 / 17 / 2007$ & $6 / 1 / 2007$ & 1 \\
\hline SW846-9060 & WETCHEM & Dissolved Organic Carbon & MW243 & 1 & $\mathrm{mg} / \mathrm{L}$ & $u$ & $5 / 15 / 2007$ & $6 / 1 / 2007$ & 1 \\
\hline SW846-9060 & WETCHEM & Dissolved Organic Carbon & MW262 & 1 & $\mathrm{mg} / \mathrm{L}$ & $\mathrm{u}$ & $5 / 16 / 2007$ & $6 / 1 / 2007$ & 1 \\
\hline sW846-9060 & WETCHEM & Dissolved Organic Carbon & MW340 & 1 & $\mathrm{mg} / \mathrm{L}$ & $\mathrm{u}$ & $5 / 23 / 2007$ & $6 / 5 / 2007$ & 1 \\
\hline SW846-9060 & WETCHEM & Dissolved Organic Carbon & MW381 & 1 & $\mathrm{mg} / \mathrm{L}$ & $\mathrm{U}$ & $5 / 22 / 2007$ & $6 / 5 / 2007$ & 1 \\
\hline
\end{tabular}




\begin{tabular}{|c|c|c|c|c|c|c|c|c|c|}
\hline Method & AnaType & Chemical Name & Station & Results & Units & $\begin{array}{c}\text { Result } \\
\text { Qualifier }\end{array}$ & Date Collected & $\begin{array}{c}\text { Date } \\
\text { Analyzed }\end{array}$ & $\begin{array}{l}\text { Detection } \\
\text { Limit }\end{array}$ \\
\hline SW846-9060 & WETCHEM & Dissolved Organic Carbon & MW66 & 1 & $\mathrm{mg} / \mathrm{L}$ & $\mathrm{U}$ & $5 / 15 / 2007$ & $6 / 1 / 2007$ & 1 \\
\hline SW846-9060 & WETCHEM & Dissolved Organic Carbon & QC & 1 & $\mathrm{mg} / \mathrm{L}$ & $U$ & $5 / 22 / 2007$ & $6 / 4 / 2007$ & 1 \\
\hline SW846-9060 & WETCHEM & Dissolved Organic Carbon & $\mathrm{QC}$ & 1 & $\mathrm{mg} / \mathrm{L}$ & $U$ & $5 / 22 / 2007$ & $6 / 4 / 2007$ & 1 \\
\hline SW846-9056 & WETCHEM & Phosphate as Phosphorous & MW125 & 1 & $\mathrm{mg} / \mathrm{L}$ & $\mathrm{U}$ & $5 / 21 / 2007$ & $5 / 22 / 2007$ & 1 \\
\hline SW846-9056 & WETCHEM & Phosphate as Phosphorous & MW168 & 1 & $\mathrm{mg} / \mathrm{L}$ & $\mathrm{BU}$ & $5 / 16 / 2007$ & $5 / 17 / 2007$ & 1 \\
\hline SW846-9056 & WETCHEM & Phosphate as Phosphorous & MW185 & 1 & $\mathrm{mg} / \mathrm{L}$ & $U$ & $5 / 23 / 2007$ & $5 / 24 / 2007$ & 1 \\
\hline SW846-9056 & WETCHEM & Phosphate as Phosphorous & MW194 & 1 & $\mathrm{mg} / \mathrm{L}$ & $\mathrm{U}$ & $5 / 17 / 2007$ & $5 / 21 / 2007$ & 1 \\
\hline SW846-9056 & WETCHEM & Phosphate as Phosphorous & MW197 & 1 & $\mathrm{mg} / \mathrm{L}$ & $U$ & $5 / 21 / 2007$ & $5 / 22 / 2007$ & 1 \\
\hline SW846-9056 & WETCHEM & Phosphate as Phosphorous & MW236 & 1 & $\mathrm{mg} / \mathrm{L}$ & $U$ & $5 / 22 / 2007$ & $5 / 23 / 2007$ & 1 \\
\hline SW846-9056 & WETCHEM & Phosphate as Phosphorous & MW236 & 1 & $\mathrm{mg} / \mathrm{L}$ & $U$ & $5 / 22 / 2007$ & $5 / 23 / 2007$ & 1 \\
\hline SW846-9056 & WETCHEM & Phosphate as Phosphorous & MW242 & 1 & $\mathrm{mg} / \mathrm{L}$ & $\mathrm{U}$ & $5 / 17 / 2007$ & $5 / 18 / 2007$ & 1 \\
\hline SW846-9056 & WETCHEM & Phosphate as Phosphorous & MW243 & 5.3 & $\mathrm{mg} / \mathrm{L}$ & $B X$ & $5 / 15 / 2007$ & $5 / 16 / 2007$ & 1 \\
\hline SW846-9056 & WETCHEM & Phosphate as Phosphorous & MW262 & 1 & $\mathrm{mg} / \mathrm{L}$ & $\mathrm{BU}$ & $5 / 16 / 2007$ & $5 / 17 / 2007$ & 1 \\
\hline SW846-9056 & WETCHEM & Phosphate as Phosphorous & MW340 & 1 & $\mathrm{mg} / \mathrm{L}$ & $U$ & $5 / 23 / 2007$ & $5 / 24 / 2007$ & 1 \\
\hline SW846-9056 & WETCHEM & Phosphate as Phosphorous & MW381 & 1 & $\mathrm{mg} / \mathrm{L}$ & U & $5 / 22 / 2007$ & $5 / 23 / 2007$ & 1 \\
\hline SW846-9056 & WETCHEM & Phosphate as Phosphorous & MW66 & 1 & $\mathrm{mg} / \mathrm{L}$ & BUX & $5 / 15 / 2007$ & $5 / 16 / 2007$ & 1 \\
\hline SW846-9056 & WETCHEM & Phosphate as Phosphorous & QC & 1 & $\mathrm{mg} / \mathrm{L}$ & U & $5 / 22 / 2007$ & $5 / 23 / 2007$ & 1 \\
\hline SW846-9056 & WETCHEM & Phosphate as Phosphorous & QC & 1 & $\mathrm{mg} / \mathrm{L}$ & $\mathrm{U}$ & $5 / 22 / 2007$ & $5 / 23 / 2007$ & 1 \\
\hline SW846-9060 & WETCHEM & Total Organic Carbon (TOC) & MW125 & 1 & $\mathrm{mg} / \mathrm{L}$ & $U$ & $5 / 21 / 2007$ & $6 / 4 / 2007$ & 1 \\
\hline SW846-9060 & WETCHEM & Total Organic Carbon (TOC) & MW168 & 1 & $\mathrm{mg} / \mathrm{L}$ & $\mathrm{U}$ & $5 / 16 / 2007$ & $6 / 1 / 2007$ & 1 \\
\hline SW846-9060 & WETCHEM & Total Organic Carbon (TOC) & MW185 & 1 & $\mathrm{mg} / \mathrm{L}$ & $\mathrm{U}$ & $5 / 23 / 2007$ & $6 / 5 / 2007$ & 1 \\
\hline SW846-9060 & WETCHEM & Total Organic Carbon (TOC) & MW194 & 1 & $\mathrm{mg} / \mathrm{L}$ & $\mathrm{U}$ & $5 / 17 / 2007$ & $6 / 4 / 2007$ & 1 \\
\hline SW846-9060 & WETCHEM & Total Organic Carbon (TOC) & MW197 & 2.3 & $\mathrm{mg} / \mathrm{L}$ & & $5 / 21 / 2007$ & $6 / 4 / 2007$ & 1 \\
\hline SW846-9060 & WETCHEM & Total Organic Carbon (TOC) & MW236 & 1 & $\mathrm{mg} / \mathrm{L}$ & $\mathrm{U}$ & $5 / 22 / 2007$ & $6 / 5 / 2007$ & 1 \\
\hline SW846-9060 & WETCHEM & Total Organic Carbon (TOC) & MW236 & 1 & $\mathrm{mg} / \mathrm{L}$ & $U$ & $5 / 22 / 2007$ & $6 / 5 / 2007$ & 1 \\
\hline SW846-9060 & WETCHEM & Total Organic Carbon (TOC) & MW242 & 1 & $\mathrm{mg} / \mathrm{L}$ & $U$ & $5 / 17 / 2007$ & $6 / 1 / 2007$ & 1 \\
\hline SW846-9060 & WETCHEM & Total Organic Carbon (TOC) & MW243 & 1 & $\mathrm{mg} / \mathrm{L}$ & $\mathrm{U}$ & $5 / 15 / 2007$ & $6 / 1 / 2007$ & 1 \\
\hline SW846-9060 & WETCHEM & Total Organic Carbon (TOC) & MW262 & 1 & $\mathrm{mg} / \mathrm{L}$ & $\mathrm{U}$ & $5 / 16 / 2007$ & $6 / 1 / 2007$ & 1 \\
\hline SW846-9060 & WETCHEM & Total Organic Carbon (TOC) & MW340 & 1 & $\mathrm{mg} / \mathrm{L}$ & $U$ & $5 / 23 / 2007$ & $6 / 5 / 2007$ & 1 \\
\hline SW846-9060 & WETCHEM & Total Organic Carbon (TOC) & MW381 & 1 & $\mathrm{mg} / \mathrm{L}$ & $U$ & $5 / 22 / 2007$ & $6 / 5 / 2007$ & 1 \\
\hline SW846-9060 & WETCHEM & Total Organic Carbon (TOC) & MW66 & 1 & $\mathrm{mg} / \mathrm{L}$ & $U$ & $5 / 15 / 2007$ & $6 / 1 / 2007$ & 1 \\
\hline SW846-9060 & WETCHEM & Total Organic Carbon (TOC) & QC & 1 & $\mathrm{mg} / \mathrm{L}$ & $U$ & $5 / 22 / 2007$ & $6 / 4 / 2007$ & 1 \\
\hline SW846-9060 & WETCHEM & Total Organic Carbon (TOC) & QC & 1 & $\mathrm{mg} / \mathrm{L}$ & $\mathrm{U}$ & $5 / 22 / 2007$ & $6 / 4 / 2007$ & 1 \\
\hline
\end{tabular}


Follow-Up Samples (December 2007) 


\begin{tabular}{|c|c|c|c|c|c|c|c|c|c|c|}
\hline Method & AnaType & Chemical Name & Station & Result & Error & Units & Qualifier & $\begin{array}{c}\text { Date } \\
\text { Collected }\end{array}$ & $\begin{array}{c}\text { Date } \\
\text { Analyzed }\end{array}$ & $\begin{array}{l}\text { Detection } \\
\text { Limit }\end{array}$ \\
\hline FS & METEO & Barometric Pressure & MW125 & 30.21 & & Inches $/ \mathrm{Hg}$ & & $12 / 19 / 2007$ & & \\
\hline FS & METEO & Barometric Pressure & MW168 & 30.21 & & Inches/Hg & & $12 / 19 / 2007$ & & \\
\hline FS & METEO & Barometric Pressure & MW185 & 30.21 & & Inches/Hg & & $12 / 19 / 2007$ & & \\
\hline FS & METEO & Barometric Pressure & MW194 & 30.21 & & Inches/Hg & & $12 / 19 / 2007$ & & \\
\hline FS & METEO & Barometric Pressure & MW197 & 30.21 & & Inches/Hg & & $12 / 19 / 2007$ & & \\
\hline FS & METEO & Barometric Pressure & MW236 & 30.21 & & Inches/Hg & & $12 / 19 / 2007$ & & \\
\hline FS & METEO & Barometric Pressure & MW242 & 30.21 & & Inches/Hg & & $12 / 19 / 2007$ & & \\
\hline FS & METEO & Barometric Pressure & MW243 & 30.21 & & Inches/Hg & & $12 / 19 / 2007$ & & \\
\hline FS & METEO & Barometric Pressure & MW262 & 30.21 & & Inches/Hg & & $12 / 19 / 2007$ & & \\
\hline FS & METEO & Barometric Pressure & MW340 & 30.21 & & Inches/Hg & & $12 / 19 / 2007$ & & \\
\hline FS & METEO & Barometric Pressure & MW381 & 30.21 & & Inches/Hg & & $12 / 19 / 2007$ & & \\
\hline FS & METEO & Barometric Pressure & MW66 & 30.21 & & Inches/Hg & & $12 / 19 / 2007$ & & \\
\hline FS & PHYSC & Depth to Water & MW125 & 54.1 & & $\mathrm{ft}$ & & $12 / 19 / 2007$ & & \\
\hline FS & PHYSC & Depth to Water & MW168 & 54.45 & & $\mathrm{ft}$ & & $12 / 19 / 2007$ & & \\
\hline FS & PHYSC & Depth to Water & MW185 & 51.26 & & $\mathrm{ft}$ & & $12 / 19 / 2007$ & & \\
\hline FS & PHYSC & Depth to Water & MW194 & 33.75 & & $\mathrm{ft}$ & & $12 / 19 / 2007$ & & \\
\hline FS & PHYSC & Depth to Water & MW197 & 46.25 & & $\mathrm{ft}$ & & $12 / 19 / 2007$ & & \\
\hline FS & PHYSC & Depth to Water & MW236 & 48.71 & & $\mathrm{ft}$ & & $12 / 19 / 2007$ & & \\
\hline FS & PHYSC & Depth to Water & MW242 & 46.84 & & $\mathrm{ft}$ & & $12 / 19 / 2007$ & & \\
\hline FS & PHYSC & Depth to Water & MW243 & 45.05 & & $\mathrm{ft}$ & & $12 / 19 / 2007$ & & \\
\hline FS & PHYSC & Depth to Water & MW262 & 50.64 & & $\mathrm{ft}$ & & $12 / 19 / 2007$ & & \\
\hline FS & PHYSC & Depth to Water & MW340 & 51.69 & & $\mathrm{ft}$ & & $12 / 19 / 2007$ & & \\
\hline FS & PHYSC & Depth to Water & MW381 & 48.71 & & $\mathrm{ft}$ & & $12 / 19 / 2007$ & & \\
\hline FS & PHYSC & Depth to Water & MW66 & 48.55 & & $\mathrm{ft}$ & & $12 / 19 / 2007$ & & \\
\hline FS & PHYSC & Dissolved Oxygen & MW125 & 2.88 & & $\mathrm{mg} / \mathrm{L}$ & & $12 / 19 / 2007$ & & \\
\hline FS & PHYSC & Dissolved Oxygen & MW168 & 3.13 & & $\mathrm{mg} / \mathrm{L}$ & & $12 / 19 / 2007$ & & \\
\hline FS & PHYSC & Dissolved Oxygen & MW185 & 1.68 & & $\mathrm{mg} / \mathrm{L}$ & & $12 / 19 / 2007$ & & \\
\hline FS & PHYSC & Dissolved Oxygen & MW194 & 3.61 & & $\mathrm{mg} / \mathrm{L}$ & & $12 / 19 / 2007$ & & \\
\hline FS & PHYSC & Dissolved Oxygen & MW197 & 0.72 & & $\mathrm{mg} / \mathrm{L}$ & & $12 / 19 / 2007$ & & \\
\hline FS & PHYSC & Dissolved Oxygen & MW236 & 6.07 & & $\mathrm{mg} / \mathrm{L}$ & & $12 / 19 / 2007$ & & \\
\hline FS & PHYSC & Dissolved Oxygen & MW242 & 0.8 & & $\mathrm{mg} / \mathrm{L}$ & & $12 / 19 / 2007$ & & \\
\hline FS & PHYSC & Dissolved Oxygen & MW243 & 3.81 & & $\mathrm{mg} / \mathrm{L}$ & & $12 / 19 / 2007$ & & \\
\hline FS & PHYSC & Dissolved Oxygen & MW262 & 0.76 & & $\mathrm{mg} / \mathrm{L}$ & & $12 / 19 / 2007$ & & \\
\hline FS & PHYSC & Dissolved Oxygen & MW340 & 3.17 & & $\mathrm{mg} / \mathrm{L}$ & & $12 / 19 / 2007$ & & \\
\hline FS & PHYSC & Dissolved Oxygen & MW381 & 6.07 & & $\mathrm{mg} / \mathrm{L}$ & & $12 / 19 / 2007$ & & \\
\hline FS & PHYSC & Dissolved Oxygen & MW66 & 5.69 & & $\mathrm{mg} / \mathrm{L}$ & & $12 / 19 / 2007$ & & \\
\hline FS & PHYSC & Oxidation-Reduction Potential & MW125 & 400 & & $\mathrm{mV}$ & & $12 / 19 / 2007$ & & \\
\hline FS & PHYSC & Oxidation-Reduction Potential & MW168 & 233 & & $\mathrm{mV}$ & & $12 / 19 / 2007$ & & \\
\hline FS & PHYSC & Oxidation-Reduction Potential & MW185 & 269 & & $\mathrm{mV}$ & & $12 / 19 / 2007$ & & \\
\hline FS & PHYSC & Oxidation-Reduction Potential & MW194 & 114 & & $\mathrm{mV}$ & & $12 / 19 / 2007$ & & \\
\hline FS & PHYSC & Oxidation-Reduction Potential & MW197 & 2 & & $\mathrm{mV}$ & & $12 / 19 / 2007$ & & \\
\hline FS & PHYSC & Oxidation-Reduction Potential & MW236 & 261 & & $\mathrm{mV}$ & & $12 / 19 / 2007$ & & \\
\hline FS & PHYSC & Oxidation-Reduction Potential & MW242 & 63 & & $\mathrm{mV}$ & & $12 / 19 / 2007$ & & \\
\hline FS & PHYSC & Oxidation-Reduction Potential & MW243 & 150 & & $\mathrm{mV}$ & & $12 / 19 / 2007$ & & \\
\hline FS & PHYSC & Oxidation-Reduction Potential & MW262 & 218 & & $\mathrm{mV}$ & & $12 / 19 / 2007$ & & \\
\hline FS & PHYSC & Oxidation-Reduction Potential & MW340 & 254 & & $\mathrm{mV}$ & & $12 / 19 / 2007$ & & \\
\hline FS & PHYSC & Oxidation-Reduction Potential & MW381 & 261 & & $\mathrm{mV}$ & & $12 / 19 / 2007$ & & \\
\hline FS & PHYSC & Oxidation-Reduction Potential & MW66 & 285 & & $\mathrm{mV}$ & & $12 / 19 / 2007$ & & \\
\hline FS & PHYSC & $\mathrm{pH}$ & MW125 & 6.11 & & Std Unit & & $12 / 19 / 2007$ & & \\
\hline FS & PHYSC & $\mathrm{pH}$ & MW168 & 5.87 & & Std Unit & & $12 / 19 / 2007$ & & \\
\hline FS & PHYSC & $\mathrm{pH}$ & MW185 & 6.1 & & Std Unit & & $12 / 19 / 2007$ & & \\
\hline FS & PHYSC & $\mathrm{pH}$ & MW194 & 6.2 & & Std Unit & & $12 / 19 / 2007$ & & \\
\hline FS & PHYSC & $\mathrm{pH}$ & MW197 & 6.13 & & Std Unit & & $12 / 19 / 2007$ & & \\
\hline FS & PHYSC & $\mathrm{pH}$ & MW236 & 6.65 & & Std Unit & & $12 / 19 / 2007$ & & \\
\hline FS & PHYSC & $\mathrm{pH}$ & MW242 & 6.09 & & Std Unit & & $12 / 19 / 2007$ & & \\
\hline FS & PHYSC & $\mathrm{pH}$ & MW243 & 5.96 & & Std Unit & & $12 / 19 / 2007$ & & \\
\hline FS & PHYSC & $\mathrm{pH}$ & MW262 & 5.97 & & Std Unit & & $12 / 19 / 2007$ & & \\
\hline FS & PHYSC & $\mathrm{pH}$ & MW340 & 6.04 & & Std Unit & & $12 / 19 / 2007$ & & \\
\hline FS & PHYSC & $\mathrm{pH}$ & MW381 & 6.65 & & Std Unit & & $12 / 19 / 2007$ & & \\
\hline FS & PHYSC & $\mathrm{pH}$ & MW66 & 6.01 & & Std Unit & & 12/19/2007 & & \\
\hline FS & PHYSC & Temperature & MW125 & 55.8 & & $\operatorname{deg} F$ & & $12 / 19 / 2007$ & & \\
\hline FS & PHYSC & Temperature & MW168 & 62.7 & & $\operatorname{deg} F$ & & $12 / 19 / 2007$ & & \\
\hline FS & PHYSC & Temperature & MW185 & 59.4 & & $\operatorname{deg} \mathrm{F}$ & & $12 / 19 / 2007$ & & \\
\hline FS & PHYSC & Temperature & MW194 & 57.6 & & $\operatorname{deg} F$ & & $12 / 19 / 2007$ & & \\
\hline FS & PHYSC & Temperature & MW197 & 57.7 & & $\operatorname{deg} F$ & & $12 / 19 / 2007$ & & \\
\hline FS & PHYSC & Temperature & MW236 & 57.8 & & $\operatorname{deg} F$ & & $12 / 19 / 2007$ & & \\
\hline FS & PHYSC & Temperature & MW242 & 57 & & $\operatorname{deg} F$ & & $12 / 19 / 2007$ & & \\
\hline FS & PHYSC & Temperature & MW243 & 57.2 & & $\operatorname{deg} \mathrm{F}$ & & $12 / 19 / 2007$ & & \\
\hline FS & PHYSC & Temperature & MW262 & 61.6 & & $\operatorname{deg} F$ & & $12 / 19 / 2007$ & & \\
\hline FS & PHYSC & Temperature & MW340 & 60.7 & & $\operatorname{deg} F$ & & $12 / 19 / 2007$ & & \\
\hline FS & PHYSC & Temperature & MW381 & 57.8 & & $\operatorname{deg} F$ & & $12 / 19 / 2007$ & & \\
\hline
\end{tabular}




\begin{tabular}{|c|c|c|}
\hline Method & AnaType & Chemical Name \\
\hline FS & PHYSC & Temperature \\
\hline RL-7100 & RADS & Technetium-99 \\
\hline RL-7100 & RADS & Technetium-99 \\
\hline RL-7100 & RADS & Technetium-99 \\
\hline RL-7100 & RADS & Technetium-99 \\
\hline RL-7100 & RADS & Technetium-99 \\
\hline RL-7100 & RADS & Technetium-99 \\
\hline RL-7100 & RADS & Technetium-99 \\
\hline RL-7100 & RADS & Technetium-99 \\
\hline RL-7100 & RADS & Technetium-99 \\
\hline RL-7100 & RADS & Technetium-99 \\
\hline $\mathrm{RL}-7100$ & RADS & Technetium-99 \\
\hline RL-7100 & RADS & Technetium-99 \\
\hline $8260 B$ & VOA & 1,1,1-Trichloroethane \\
\hline 8260B & VOA & 1,1,1-Trichloroethane \\
\hline $8260 B$ & VOA & 1,1,1-Trichloroethane \\
\hline 8260B & VOA & 1,1,1-Trichloroethane \\
\hline $8260 B$ & VOA & 1,1,1-Trichloroethane \\
\hline 8260B & VOA & 1,1,1-Trichloroethane \\
\hline 8260B & VOA & 1,1,1-Trichloroethane \\
\hline $8260 B$ & VOA & 1,1,1-Trichloroethane \\
\hline 8260B & VOA & 1,1,1-Trichloroethane \\
\hline 8260B & VOA & 1,1,1-Trichloroethane \\
\hline 8260B & VOA & 1,1,1-Trichloroethane \\
\hline 8260B & VOA & 1,1,1-Trichloroethane \\
\hline 8260B & VOA & 1,1,1-Trichloroethane \\
\hline 8260B & VOA & 1,1,1-Trichloroethane \\
\hline 8260B & VOA & 1,1,2,2-Tetrachloroethane \\
\hline 8260B & VOA & 1,1,2,2-Tetrachloroethane \\
\hline 8260B & VOA & 1,1,2,2-Tetrachloroethane \\
\hline 8260B & VOA & 1,1,2,2-Tetrachloroethane \\
\hline 8260B & VOA & 1,1,2,2-Tetrachloroethane \\
\hline 8260B & VOA & 1,1,2,2-Tetrachloroethane \\
\hline 8260B & VOA & 1,1,2,2-Tetrachloroethane \\
\hline 8260B & VOA & 1,1,2,2-Tetrachloroethane \\
\hline 8260B & VOA & 1,1,2,2-Tetrachloroethane \\
\hline 8260B & VOA & 1,1,2,2-Tetrachloroethane \\
\hline 8260B & VOA & 1,1,2,2-Tetrachloroethane \\
\hline 8260B & VOA & 1,1,2,2-Tetrachloroethane \\
\hline $8260 B$ & VOA & $1,1,2,2$-Tetrachloroethane \\
\hline 8260B & VOA & 1,1,2,2-Tetrachloroethane \\
\hline $8260 B$ & VOA & 1,1,2-Trichloroethane \\
\hline 8260B & VOA & 1,1,2-Trichloroethane \\
\hline 8260B & VOA & 1,1,2-Trichloroethane \\
\hline 8260B & VOA & 1,1,2-Trichloroethane \\
\hline 8260B & VOA & 1,1,2-Trichloroethane \\
\hline $8260 B$ & VOA & 1,1,2-Trichloroethane \\
\hline 8260B & VOA & 1,1,2-Trichloroethane \\
\hline 8260B & VOA & 1,1,2-Trichloroethane \\
\hline 8260B & VOA & 1,1,2-Trichloroethane \\
\hline 8260B & VOA & 1,1,2-Trichloroethane \\
\hline 8260B & VOA & 1,1,2-Trichloroethane \\
\hline 8260B & VOA & 1,1,2-Trichloroethane \\
\hline 8260B & VOA & 1,1,2-Trichloroethane \\
\hline 8260B & VOA & 1,1,2-Trichloroethane \\
\hline 8260B & VOA & 1,1-Dichloroethane \\
\hline 8260B & VOA & 1,1-Dichloroethane \\
\hline 8260B & VOA & 1,1-Dichloroethane \\
\hline 8260B & VOA & 1,1-Dichloroethane \\
\hline 8260B & VOA & 1,1-Dichloroethane \\
\hline $8260 B$ & VOA & 1,1-Dichloroethane \\
\hline 8260B & VOA & 1,1-Dichloroethane \\
\hline 8260B & VOA & 1,1-Dichloroethane \\
\hline 8260B & VOA & 1,1-Dichloroethane \\
\hline $8260 \mathrm{~B}$ & VOA & 1,1-Dichloroethane \\
\hline 8260B & VOA & 1,1-Dichloroethane \\
\hline 8260B & VOA & 1,1-Dichloroethane \\
\hline 8260B & VOA & 1,1-Dichloroethane \\
\hline 8260B & VOA & 1,1-Dichloroethane \\
\hline 8260B & VOA & 1,1-Dichloroethene \\
\hline 8260B & VOA & 1,1-Dichloroethene \\
\hline
\end{tabular}

\begin{tabular}{|c|c|c|}
\hline Station & Result & Error \\
\hline MW66 & 60.3 & \\
\hline MW125 & 220 & 17.8 \\
\hline MW168 & 2400 & 45.1 \\
\hline MW185 & 696 & 26.4 \\
\hline MW194 & 6.11 & 11.5 \\
\hline MW197 & -8.38 & 11.4 \\
\hline MW236 & 29.1 & 12.7 \\
\hline MW242 & 110 & 15.1 \\
\hline MW243 & 306 & 19.4 \\
\hline MW262 & 519 & 23.4 \\
\hline MW340 & 647 & 25.6 \\
\hline MW381 & 21.5 & 12.5 \\
\hline MW66 & 530 & 23.7 \\
\hline MW125 & 25 & \\
\hline MW168 & 6.2 & \\
\hline MW185 & 120 & \\
\hline MW194 & 5 & \\
\hline MW197 & 5 & \\
\hline MW236 & 5 & \\
\hline MW242 & 5 & \\
\hline MW243 & 25 & \\
\hline MW262 & 50 & \\
\hline MW340 & 400 & \\
\hline MW381 & 5 & \\
\hline MW66 & 25 & \\
\hline QC & 5 & \\
\hline QC & 5 & \\
\hline MW125 & 25 & \\
\hline MW168 & 6.2 & \\
\hline MW185 & 120 & \\
\hline MW194 & 5 & \\
\hline MW197 & 5 & \\
\hline MW236 & 5 & \\
\hline MW242 & 5 & \\
\hline MW243 & 25 & \\
\hline MW262 & 50 & \\
\hline MW340 & 400 & \\
\hline MW381 & 5 & \\
\hline MW66 & 25 & \\
\hline QC & 5 & \\
\hline QC & 5 & \\
\hline MW125 & 25 & \\
\hline MW168 & 6.2 & \\
\hline MW185 & 120 & \\
\hline MW194 & 5 & \\
\hline MW197 & 5 & \\
\hline MW236 & 5 & \\
\hline MW242 & 5 & \\
\hline MW243 & 25 & \\
\hline MW262 & 50 & \\
\hline MW340 & 400 & \\
\hline MW381 & 5 & \\
\hline MW66 & 25 & \\
\hline QC & 5 & \\
\hline QC & 5 & \\
\hline MW125 & 5 & \\
\hline MW168 & 1.2 & \\
\hline MW185 & 25 & \\
\hline MW194 & 1 & \\
\hline MW197 & 1 & \\
\hline MW236 & 1 & \\
\hline MW242 & 1 & \\
\hline MW243 & 5 & \\
\hline MW262 & 10 & \\
\hline MW340 & 80 & \\
\hline MW381 & 1 & \\
\hline MW66 & 5 & \\
\hline QC & 1 & \\
\hline QC & 1 & \\
\hline MW125 & 5 & \\
\hline MW168 & 2.8 & \\
\hline
\end{tabular}

\begin{tabular}{|c|c|c|c|c|}
\hline $\begin{array}{l}\text { Units } \\
\operatorname{deg} F\end{array}$ & Qualifier & $\begin{array}{c}\text { Date } \\
\text { Collected } \\
12 / 19 / 2007\end{array}$ & $\begin{array}{c}\text { Date } \\
\text { Analyzed }\end{array}$ & $\begin{array}{l}\text { Detection } \\
\text { Limit }\end{array}$ \\
\hline $\mathrm{pCi} / \mathrm{L}$ & & $12 / 19 / 2007$ & $1 / 14 / 2008$ & 16.7 \\
\hline $\mathrm{pCi} / \mathrm{L}$ & & $12 / 19 / 2007$ & $1 / 14 / 2008$ & 16.7 \\
\hline $\mathrm{pCi} / \mathrm{L}$ & & $12 / 19 / 2007$ & $1 / 16 / 2008$ & 16.1 \\
\hline $\mathrm{pCi} / \mathrm{L}$ & $U$ & $12 / 19 / 2007$ & $1 / 16 / 2008$ & 16.1 \\
\hline $\mathrm{pCi} / \mathrm{L}$ & $U$ & $12 / 19 / 2007$ & $1 / 14 / 2008$ & 16.7 \\
\hline $\mathrm{pCi} / \mathrm{L}$ & & $12 / 19 / 2007$ & $1 / 14 / 2008$ & 16.7 \\
\hline $\mathrm{pCi} / \mathrm{L}$ & & $12 / 19 / 2007$ & $1 / 14 / 2008$ & 16.7 \\
\hline $\mathrm{pCi} / \mathrm{L}$ & & $12 / 19 / 2007$ & $1 / 16 / 2008$ & 16.1 \\
\hline $\mathrm{pCi} / \mathrm{L}$ & & $12 / 19 / 2007$ & $1 / 16 / 2008$ & 16.1 \\
\hline $\mathrm{pCi} / \mathrm{L}$ & & $12 / 19 / 2007$ & $1 / 16 / 2008$ & 16.1 \\
\hline $\mathrm{pCi} / \mathrm{L}$ & & $12 / 19 / 2007$ & $1 / 14 / 2008$ & 16.7 \\
\hline $\mathrm{pCi} / \mathrm{L}$ & & $12 / 19 / 2007$ & 1/16/2008 & 16.1 \\
\hline $\mathrm{ug} / \mathrm{L}$ & $U$ & $12 / 19 / 2007$ & $12 / 27 / 2007$ & 25 \\
\hline ug/L & $U$ & $12 / 19 / 2007$ & $12 / 27 / 2007$ & 6.2 \\
\hline ug/L & $U$ & $12 / 19 / 2007$ & $12 / 27 / 2007$ & 120 \\
\hline ug/L & $U$ & $12 / 19 / 2007$ & $12 / 27 / 2007$ & 5 \\
\hline ug/L & $\mathrm{U}$ & $12 / 19 / 2007$ & $12 / 27 / 2007$ & 5 \\
\hline $\mathrm{ug} / \mathrm{L}$ & $U$ & $12 / 19 / 2007$ & $12 / 27 / 2007$ & 5 \\
\hline ug/L & $U$ & $12 / 19 / 2007$ & $12 / 27 / 2007$ & 5 \\
\hline ug/L & $U$ & $12 / 19 / 2007$ & $12 / 27 / 2007$ & 25 \\
\hline ug/L & $\mathrm{U}$ & $12 / 19 / 2007$ & $12 / 27 / 2007$ & 50 \\
\hline ug/L & $\mathrm{U}$ & $12 / 19 / 2007$ & $12 / 27 / 2007$ & 400 \\
\hline ug/L & $U$ & $12 / 19 / 2007$ & $12 / 27 / 2007$ & 5 \\
\hline ug/L & $\mathrm{U}$ & $12 / 19 / 2007$ & $12 / 27 / 2007$ & 25 \\
\hline ug/L & $\mathrm{U}$ & $12 / 19 / 2007$ & $12 / 27 / 2007$ & 5 \\
\hline $\mathrm{ug} / \mathrm{L}$ & $U$ & $12 / 19 / 2007$ & $12 / 27 / 2007$ & 5 \\
\hline ug/L & $U$ & $12 / 19 / 2007$ & $12 / 27 / 2007$ & 25 \\
\hline ug/L & $\mathrm{U}$ & $12 / 19 / 2007$ & $12 / 27 / 2007$ & 6.2 \\
\hline ug/L & $\mathrm{U}$ & $12 / 19 / 2007$ & $12 / 27 / 2007$ & 120 \\
\hline ug/L & $U$ & $12 / 19 / 2007$ & $12 / 27 / 2007$ & 5 \\
\hline ug/L & $U$ & $12 / 19 / 2007$ & $12 / 27 / 2007$ & 5 \\
\hline ug/L & $U$ & $12 / 19 / 2007$ & $12 / 27 / 2007$ & 5 \\
\hline ug/L & $\mathrm{U}$ & $12 / 19 / 2007$ & $12 / 27 / 2007$ & 5 \\
\hline ug/L & $U$ & $12 / 19 / 2007$ & $12 / 27 / 2007$ & 25 \\
\hline ug/L & $\mathrm{U}$ & $12 / 19 / 2007$ & $12 / 27 / 2007$ & 50 \\
\hline ug/L & $\mathrm{U}$ & $12 / 19 / 2007$ & $12 / 27 / 2007$ & 400 \\
\hline $\mathrm{ug} / \mathrm{L}$ & U & $12 / 19 / 2007$ & $12 / 27 / 2007$ & 5 \\
\hline ug/L & $U$ & $12 / 19 / 2007$ & $12 / 27 / 2007$ & 25 \\
\hline ug/L & $U$ & $12 / 19 / 2007$ & $12 / 27 / 2007$ & 5 \\
\hline ug/L & $U$ & $12 / 19 / 2007$ & $12 / 27 / 2007$ & 5 \\
\hline ug/L & $U$ & $12 / 19 / 2007$ & $12 / 27 / 2007$ & 25 \\
\hline ug/L & $U$ & $12 / 19 / 2007$ & $12 / 27 / 2007$ & 6.2 \\
\hline ug/L & $U$ & $12 / 19 / 2007$ & $12 / 27 / 2007$ & 120 \\
\hline ug/L & $\mathrm{U}$ & $12 / 19 / 2007$ & $12 / 27 / 2007$ & 5 \\
\hline ug/L & U & $12 / 19 / 2007$ & $12 / 27 / 2007$ & 5 \\
\hline ug/L & $U$ & $12 / 19 / 2007$ & $12 / 27 / 2007$ & 5 \\
\hline ug/L & $U$ & $12 / 19 / 2007$ & $12 / 27 / 2007$ & 5 \\
\hline ug/L & $\mathrm{U}$ & $12 / 19 / 2007$ & $12 / 27 / 2007$ & 25 \\
\hline ug/L & $\mathrm{U}$ & $12 / 19 / 2007$ & $12 / 27 / 2007$ & 50 \\
\hline ug/L & $U$ & $12 / 19 / 2007$ & $12 / 27 / 2007$ & 400 \\
\hline ug/L & $U$ & $12 / 19 / 2007$ & $12 / 27 / 2007$ & 5 \\
\hline ug/L & $\mathrm{U}$ & $12 / 19 / 2007$ & $12 / 27 / 2007$ & 25 \\
\hline ug/L & $U$ & $12 / 19 / 2007$ & $12 / 27 / 2007$ & 5 \\
\hline ug/L & $U$ & $12 / 19 / 2007$ & $12 / 27 / 2007$ & 5 \\
\hline ug/L & $U$ & $12 / 19 / 2007$ & $12 / 27 / 2007$ & 5 \\
\hline ug/L & $U$ & $12 / 19 / 2007$ & $12 / 27 / 2007$ & 1.2 \\
\hline ug/L & $U$ & $12 / 19 / 2007$ & $12 / 27 / 2007$ & 25 \\
\hline ug/L & $U$ & $12 / 19 / 2007$ & $12 / 27 / 2007$ & 1 \\
\hline ug/L & $U$ & $12 / 19 / 2007$ & $12 / 27 / 2007$ & 1 \\
\hline ug/L & $U$ & $12 / 19 / 2007$ & $12 / 27 / 2007$ & 1 \\
\hline ug/L & $U$ & $12 / 19 / 2007$ & $12 / 27 / 2007$ & 1 \\
\hline ug/L & $U$ & $12 / 19 / 2007$ & $12 / 27 / 2007$ & 5 \\
\hline ug/L & $U$ & $12 / 19 / 2007$ & $12 / 27 / 2007$ & 10 \\
\hline ug/L & $U$ & $12 / 19 / 2007$ & $12 / 27 / 2007$ & 80 \\
\hline ug/L & $U$ & $12 / 19 / 2007$ & $12 / 27 / 2007$ & 1 \\
\hline ug/L & $U$ & $12 / 19 / 2007$ & $12 / 27 / 2007$ & 5 \\
\hline ug/L & $U$ & $12 / 19 / 2007$ & $12 / 27 / 2007$ & 1 \\
\hline ug/L & $U$ & $12 / 19 / 2007$ & $12 / 27 / 2007$ & 1 \\
\hline ug/L & $U$ & $12 / 19 / 2007$ & $12 / 27 / 2007$ & 5 \\
\hline ug/L & $\mathrm{D}$ & $12 / 19 / 2007$ & $12 / 27 / 2007$ & 1.2 \\
\hline
\end{tabular}




\begin{tabular}{|c|c|c|}
\hline Method & AnaType & Chemical Name \\
\hline 8260B & VOA & 1,1-Dichloroethene \\
\hline 8260B & VOA & 1,1-Dichloroethene \\
\hline $8260 \mathrm{~B}$ & VOA & 1,1-Dichloroethene \\
\hline 8260B & VOA & 1,1-Dichloroethene \\
\hline $8260 \mathrm{~B}$ & VOA & 1,1-Dichloroethene \\
\hline $8260 B$ & VOA & 1,1-Dichloroethene \\
\hline 8260B & VOA & 1,1-Dichloroethene \\
\hline 8260B & VOA & 1,1-Dichloroethene \\
\hline 8260B & VOA & 1,1-Dichloroethene \\
\hline 8260B & VOA & 1,1-Dichloroethene \\
\hline 8260B & VOA & 1,1-Dichloroethene \\
\hline 8260B & VOA & 1,1-Dichloroethene \\
\hline $8260 B$ & VOA & 1,2-Dichloroethane \\
\hline $8260 B$ & VOA & 1,2-Dichloroethane \\
\hline 8260B & VOA & 1,2-Dichloroethane \\
\hline $8260 B$ & VOA & 1,2-Dichloroethane \\
\hline $8260 B$ & VOA & 1,2-Dichloroethane \\
\hline 8260B & VOA & 1,2-Dichloroethane \\
\hline 8260B & VOA & 1,2-Dichloroethane \\
\hline $8260 \mathrm{~B}$ & VOA & 1,2-Dichloroethane \\
\hline $8260 B$ & VOA & 1,2-Dichloroethane \\
\hline $8260 B$ & VOA & 1,2-Dichloroethane \\
\hline 8260B & VOA & 1,2-Dichloroethane \\
\hline 8260B & VOA & 1,2-Dichloroethane \\
\hline $8260 \mathrm{~B}$ & VOA & 1,2-Dichloroethane \\
\hline 8260B & VOA & 1,2-Dichloroethane \\
\hline $8260 B$ & VOA & 1,2-Dichloropropane \\
\hline $8260 B$ & VOA & 1,2-Dichloropropane \\
\hline 8260B & VOA & 1,2-Dichloropropane \\
\hline 8260B & VOA & 1,2-Dichloropropane \\
\hline $8260 B$ & VOA & 1,2-Dichloropropane \\
\hline 8260B & VOA & 1,2-Dichloropropane \\
\hline $8260 B$ & VOA & 1,2-Dichloropropane \\
\hline 8260B & VOA & 1,2-Dichloropropane \\
\hline $8260 \mathrm{~B}$ & VOA & 1,2-Dichloropropane \\
\hline $8260 B$ & VOA & 1,2-Dichloropropane \\
\hline 8260B & VOA & 1,2-Dichloropropane \\
\hline 8260B & VOA & 1,2-Dichloropropane \\
\hline $8260 \mathrm{~B}$ & VOA & 1,2-Dichloropropane \\
\hline 8260B & VOA & 1,2-Dichloropropane \\
\hline 8260B & VOA & 1,2-Dimethylbenzene \\
\hline 8260B & VOA & 1,2-Dimethylbenzene \\
\hline $8260 B$ & VOA & 1,2-Dimethylbenzene \\
\hline 8260B & VOA & 1,2-Dimethylbenzene \\
\hline 8260B & VOA & 1,2-Dimethylbenzene \\
\hline $8260 \mathrm{~B}$ & VOA & 1,2-Dimethylbenzene \\
\hline $8260 B$ & VOA & 1,2-Dimethylbenzene \\
\hline 8260B & VOA & 1,2-Dimethylbenzene \\
\hline 8260B & VOA & 1,2-Dimethylbenzene \\
\hline 8260B & VOA & 1,2-Dimethylbenzene \\
\hline 8260B & VOA & 1,2-Dimethylbenzene \\
\hline 8260B & VOA & 1,2-Dimethylbenzene \\
\hline 8260B & VOA & 1,2-Dimethylbenzene \\
\hline $8260 B$ & VOA & 1,2-Dimethylbenzene \\
\hline $8260 \mathrm{~B}$ & VOA & 2-Butanone \\
\hline $8260 \mathrm{~B}$ & VOA & 2-Butanone \\
\hline $8260 B$ & VOA & 2-Butanone \\
\hline 8260B & VOA & 2-Butanone \\
\hline 8260B & VOA & 2-Butanone \\
\hline 8260B & VOA & 2-Butanone \\
\hline 8260B & VOA & 2-Butanone \\
\hline $8260 B$ & VOA & 2-Butanone \\
\hline 8260B & VOA & 2-Butanone \\
\hline 8260B & VOA & 2-Butanone \\
\hline $8260 B$ & VOA & 2-Butanone \\
\hline 8260B & VOA & 2-Butanone \\
\hline 8260B & VOA & 2-Butanone \\
\hline $8260 B$ & VOA & 2-Butanone \\
\hline $8260 B$ & VOA & 2-Hexanone \\
\hline 8260B & VOA & 2-Hexanone \\
\hline 8260B & VOA & 2-Hexanone \\
\hline
\end{tabular}

\begin{tabular}{|c|c|c|}
\hline Station & Result Error & Units \\
\hline MW185 & 25 & $\mathrm{ug} / \mathrm{L}$ \\
\hline MW194 & 1 & $\mathrm{ug} / \mathrm{L}$ \\
\hline MW197 & 1 & $\mathrm{ug} / \mathrm{L}$ \\
\hline MW236 & 1 & $\mathrm{ug} / \mathrm{L}$ \\
\hline MW242 & 1.8 & $\mathrm{ug} / \mathrm{L}$ \\
\hline MW243 & 5 & $\mathrm{ug} / \mathrm{L}$ \\
\hline MW262 & 10 & $\mathrm{ug} / \mathrm{L}$ \\
\hline MW340 & 80 & $\mathrm{ug} / \mathrm{L}$ \\
\hline MW381 & 1 & $\mathrm{ug} / \mathrm{L}$ \\
\hline MW66 & 5 & $\mathrm{ug} / \mathrm{L}$ \\
\hline $\mathrm{QC}$ & 1 & $\mathrm{ug} / \mathrm{L}$ \\
\hline QC & 1 & $\mathrm{ug} / \mathrm{L}$ \\
\hline MW125 & 25 & $\mathrm{ug} / \mathrm{L}$ \\
\hline MW168 & 6.2 & $\mathrm{ug} / \mathrm{L}$ \\
\hline MW185 & 120 & $\mathrm{ug} / \mathrm{L}$ \\
\hline MW194 & 5 & $\mathrm{ug} / \mathrm{L}$ \\
\hline MW197 & 5 & $\mathrm{ug} / \mathrm{L}$ \\
\hline MW236 & 5 & $\mathrm{ug} / \mathrm{L}$ \\
\hline MW242 & 5 & $\mathrm{ug} / \mathrm{L}$ \\
\hline MW243 & 25 & $\mathrm{ug} / \mathrm{L}$ \\
\hline MW262 & 50 & $\mathrm{ug} / \mathrm{L}$ \\
\hline MW340 & 400 & $\mathrm{ug} / \mathrm{L}$ \\
\hline MW381 & 5 & $\mathrm{ug} / \mathrm{L}$ \\
\hline MW66 & 25 & $\mathrm{ug} / \mathrm{L}$ \\
\hline $\mathrm{QC}$ & 5 & $\mathrm{ug} / \mathrm{L}$ \\
\hline QC & 5 & $\mathrm{ug} / \mathrm{L}$ \\
\hline MW125 & 25 & $\mathrm{ug} / \mathrm{L}$ \\
\hline MW168 & 6.2 & $\mathrm{ug} / \mathrm{L}$ \\
\hline MW185 & 120 & $\mathrm{ug} / \mathrm{L}$ \\
\hline MW194 & 5 & $\mathrm{ug} / \mathrm{L}$ \\
\hline MW197 & 5 & $\mathrm{ug} / \mathrm{L}$ \\
\hline MW236 & 5 & $\mathrm{ug} / \mathrm{L}$ \\
\hline MW242 & 5 & $\mathrm{ug} / \mathrm{L}$ \\
\hline MW243 & 25 & $\mathrm{ug} / \mathrm{L}$ \\
\hline MW262 & 50 & $\mathrm{ug} / \mathrm{L}$ \\
\hline MW340 & 400 & $\mathrm{ug} / \mathrm{L}$ \\
\hline MW381 & 5 & $\mathrm{ug} / \mathrm{L}$ \\
\hline MW66 & 25 & $\mathrm{ug} / \mathrm{L}$ \\
\hline $\mathrm{QC}$ & 5 & $\mathrm{ug} / \mathrm{L}$ \\
\hline QC & 5 & $\mathrm{ug} / \mathrm{L}$ \\
\hline MW125 & 25 & $\mathrm{ug} / \mathrm{L}$ \\
\hline MW168 & 6.2 & $\mathrm{ug} / \mathrm{L}$ \\
\hline MW185 & 120 & $\mathrm{ug} / \mathrm{L}$ \\
\hline MW194 & 5 & $\mathrm{ug} / \mathrm{L}$ \\
\hline MW197 & 5 & $\mathrm{ug} / \mathrm{L}$ \\
\hline MW236 & 5 & $\mathrm{ug} / \mathrm{L}$ \\
\hline MW242 & 5 & $\mathrm{ug} / \mathrm{L}$ \\
\hline MW243 & 25 & $\mathrm{ug} / \mathrm{L}$ \\
\hline MW262 & 50 & $\mathrm{ug} / \mathrm{L}$ \\
\hline MW340 & 400 & $\mathrm{ug} / \mathrm{L}$ \\
\hline MW381 & 5 & $\mathrm{ug} / \mathrm{L}$ \\
\hline MW66 & 25 & $\mathrm{ug} / \mathrm{L}$ \\
\hline $\mathrm{QC}$ & 5 & $\mathrm{ug} / \mathrm{L}$ \\
\hline QC & 5 & $\mathrm{ug} / \mathrm{L}$ \\
\hline MW125 & 50 & $\mathrm{ug} / \mathrm{L}$ \\
\hline MW168 & 12 & $\mathrm{ug} / \mathrm{L}$ \\
\hline MW185 & 250 & $\mathrm{ug} / \mathrm{L}$ \\
\hline MW194 & 10 & $\mathrm{ug} / \mathrm{L}$ \\
\hline MW197 & 10 & $\mathrm{ug} / \mathrm{L}$ \\
\hline MW236 & 10 & $\mathrm{ug} / \mathrm{L}$ \\
\hline MW242 & 10 & $\mathrm{ug} / \mathrm{L}$ \\
\hline MW243 & 50 & $\mathrm{ug} / \mathrm{L}$ \\
\hline MW262 & 100 & $\mathrm{ug} / \mathrm{L}$ \\
\hline MW340 & 800 & $\mathrm{ug} / \mathrm{L}$ \\
\hline MW381 & 10 & $\mathrm{ug} / \mathrm{L}$ \\
\hline MW66 & 50 & $\mathrm{ug} / \mathrm{L}$ \\
\hline QC & 10 & $\mathrm{ug} / \mathrm{L}$ \\
\hline $\mathrm{QC}$ & 10 & $\mathrm{ug} / \mathrm{L}$ \\
\hline MW125 & 50 & $\mathrm{ug} / \mathrm{L}$ \\
\hline MW168 & 12 & $\mathrm{ug} / \mathrm{L}$ \\
\hline MW185 & 250 & $\mathrm{ug} / \mathrm{L}$ \\
\hline
\end{tabular}

$u g / L$

ug/L

ug/L

ug/L

ug/L

$\mathrm{ug} / \mathrm{L}$

ug/L

ug/L

ug/L

$\mathrm{ug} / \mathrm{L}$

ug/L

ug/L

ug/L

ug/L

ug/L

ug/L

ug/L

ug/L

ug/L

ug/L

ug/L

$\mathrm{ug} / \mathrm{L}$

ug/L

ug/L

ug/L

$u g / L$

ug/L

ug/L

ug/L

ug/L

ug/L

ug/L

$u g / L$

$\mathrm{ug} / \mathrm{L}$

ug/L

$u g / L$

$\mathrm{ug} / \mathrm{L}$

$\mathrm{ug} / \mathrm{L}$

ug/L

$u g / L$

$\mathrm{ug} / \mathrm{L}$

ug/L

ug/L

ug/L

$\mathrm{ug} / \mathrm{L}$

ug/L

ug/L

ug/L

ug/L

$U$

\section{Qualifier \\ Qualifier}

$\mathrm{U} \quad 12 / 19 / 2007$

U 12/19/2007

U $\quad 12 / 19 / 2007$

$12 / 19 / 2007$

$12 / 19 / 2007$

$12 / 19 / 2007$

$12 / 19 / 2007$

$12 / 19 / 2007$

$12 / 19 / 2007$

$12 / 19 / 2007$

$12 / 19 / 2007$

$12 / 19 / 2007$

$12 / 19 / 2007$

$12 / 19 / 2007$

$12 / 19 / 2007$

$12 / 19 / 2007$

$12 / 19 / 2007$

$12 / 19 / 2007$

$12 / 19 / 2007$

$12 / 19 / 2007$

$12 / 19 / 2007$

$12 / 19 / 2007$

$12 / 19 / 2007$

$12 / 19 / 2007$

$12 / 19 / 2007$

$12 / 19 / 2007$

$12 / 19 / 2007$

$12 / 19 / 2007$

$12 / 19 / 2007$

$12 / 19 / 2007$

$12 / 19 / 2007$

$12 / 19 / 2007$

$12 / 19 / 2007$

$12 / 19 / 2007$

$12 / 19 / 2007$

$12 / 19 / 2007$

$12 / 19 / 2007$

$12 / 19 / 2007$

$12 / 19 / 2007$

$12 / 19 / 2007$

$12 / 19 / 2007$

$12 / 19 / 2007$

$12 / 19 / 2007$

$12 / 19 / 2007$

$12 / 19 / 2007$

$12 / 19 / 2007$

$12 / 19 / 2007$

$12 / 19 / 2007$

$12 / 19 / 2007$

$12 / 19 / 2007$

$12 / 19 / 2007$

$12 / 19 / 2007$

$12 / 19 / 2007$

$12 / 19 / 2007$

$12 / 19 / 2007$

$12 / 19 / 2007$

$12 / 19 / 2007$

$12 / 19 / 2007$

$12 / 19 / 2007$

$12 / 19 / 2007$

$12 / 19 / 2007$

$12 / 19 / 2007$

$12 / 19 / 2007$

$12 / 19 / 2007$

$12 / 19 / 2007$

$12 / 19 / 2007$

$12 / 19 / 2007$

$12 / 19 / 2007$

$12 / 19 / 2007$

$12 / 19 / 2007$
Date

Analyzed

12/27/2007

$12 / 27 / 2007$

2/27/2007

$12 / 27 / 2007$

$12 / 27 / 2007$

$12 / 27 / 2007$

$12 / 27 / 2007$

2/27/2007

$12 / 27 / 2007$

$2 / 27 / 2007$

$12 / 27 / 2007$

$12 / 27 / 2007$

2/27/2007

$12 / 27 / 2007$

$12 / 27 / 2007$

$12 / 27 / 2007$

$12 / 27 / 2007$

$12 / 27 / 2007$

$12 / 27 / 2007$

$12 / 27 / 2007$

$12 / 27 / 2007$

$12 / 27 / 2007$

$12 / 27 / 2007$

$12 / 27 / 2007$

$12 / 27 / 2007$

$12 / 27 / 2007$

$12 / 27 / 2007$

$12 / 27 / 2007$

$12 / 27 / 2007$

$12 / 27 / 2007$

$12 / 27 / 2007$

$12 / 27 / 2007$

$12 / 27 / 2007$

$12 / 27 / 2007$

$12 / 27 / 2007$

$12 / 27 / 2007$

$12 / 27 / 2007$

$12 / 27 / 2007$

$12 / 27 / 2007$

$12 / 27 / 2007$

$12 / 27 / 2007$

$12 / 27 / 2007$

$12 / 27 / 2007$

$12 / 27 / 2007$

$12 / 27 / 2007$

$12 / 27 / 2007$

$12 / 27 / 2007$

$12 / 27 / 2007$

$12 / 27 / 2007$

$12 / 27 / 2007$

$12 / 27 / 2007$

$12 / 27 / 2007$

$12 / 27 / 2007$

$12 / 27 / 2007$

$12 / 27 / 2007$

$12 / 27 / 2007$

$12 / 27 / 2007$

$12 / 27 / 2007$

$12 / 27 / 2007$

$12 / 27 / 2007$

$12 / 27 / 2007$

$12 / 27 / 2007$

$12 / 27 / 2007$

$12 / 27 / 2007$

$12 / 27 / 2007$

$12 / 27 / 2007$

$12 / 27 / 2007$

$12 / 27 / 2007$

$12 / 27 / 2007$

$12 / 27 / 2007$

$12 / 27 / 2007$
Detection

Limit

25

10

80

1

25

6.2

20

5

25

50

5

25

5

6.2

120

5

400

25

5

25

120

5

5

25

400

25

5

50
12

250

10

10

10

10

100

800

10

50

10

10

12 


\begin{tabular}{|c|c|c|c|c|c|c|c|c|c|c|}
\hline Method & AnaType & Chemical Name & Station & Result & Error & Units & Qualifier & $\begin{array}{c}\text { Date } \\
\text { Collected }\end{array}$ & $\begin{array}{c}\text { Date } \\
\text { Analyzed }\end{array}$ & $\begin{array}{l}\text { Detection } \\
\text { Limit }\end{array}$ \\
\hline 8260B & VOA & 2-Hexanone & MW194 & 10 & & ug/L & $U$ & $12 / 19 / 2007$ & $12 / 27 / 2007$ & 10 \\
\hline 8260B & VOA & 2-Hexanone & MW197 & 10 & & ug/L & $U$ & $12 / 19 / 2007$ & $12 / 27 / 2007$ & 10 \\
\hline $8260 B$ & VOA & 2-Hexanone & MW236 & 10 & & ug/L & $U$ & $12 / 19 / 2007$ & $12 / 27 / 2007$ & 10 \\
\hline $8260 B$ & VOA & 2-Hexanone & MW242 & 10 & & ug/L & $U$ & $12 / 19 / 2007$ & $12 / 27 / 2007$ & 10 \\
\hline $8260 \mathrm{~B}$ & VOA & 2-Hexanone & MW243 & 50 & & $\mathrm{ug} / \mathrm{L}$ & $U$ & $12 / 19 / 2007$ & $12 / 27 / 2007$ & 50 \\
\hline $8260 B$ & VOA & 2-Hexanone & MW262 & 100 & & ug/L & $U$ & $12 / 19 / 2007$ & $12 / 27 / 2007$ & 100 \\
\hline $8260 B$ & VOA & 2-Hexanone & MW340 & 800 & & ug/L & $U$ & $12 / 19 / 2007$ & $12 / 27 / 2007$ & 800 \\
\hline $8260 B$ & VOA & 2-Hexanone & MW381 & 10 & & $\mathrm{ug} / \mathrm{L}$ & $U$ & $12 / 19 / 2007$ & $12 / 27 / 2007$ & 10 \\
\hline $8260 B$ & VOA & 2-Hexanone & MW66 & 50 & & $\mathrm{ug} / \mathrm{L}$ & $U$ & $12 / 19 / 2007$ & $12 / 27 / 2007$ & 50 \\
\hline 8260B & VOA & 2-Hexanone & QC & 10 & & $\mathrm{ug} / \mathrm{L}$ & $U$ & $12 / 19 / 2007$ & $12 / 27 / 2007$ & 10 \\
\hline $8260 B$ & VOA & 2-Hexanone & QC & 10 & & ug/L & $U$ & $12 / 19 / 2007$ & $12 / 27 / 2007$ & 10 \\
\hline $8260 B$ & VOA & 4-Methyl-2-pentanone & MW125 & 50 & & $\mathrm{ug} / \mathrm{L}$ & $U$ & $12 / 19 / 2007$ & $12 / 27 / 2007$ & 50 \\
\hline $8260 B$ & VOA & 4-Methyl-2-pentanone & MW168 & 12 & & $\mathrm{ug} / \mathrm{L}$ & $U$ & $12 / 19 / 2007$ & $12 / 27 / 2007$ & 12 \\
\hline $8260 B$ & VOA & 4-Methyl-2-pentanone & MW185 & 250 & & $\mathrm{ug} / \mathrm{L}$ & $U$ & $12 / 19 / 2007$ & $12 / 27 / 2007$ & 250 \\
\hline $8260 B$ & VOA & 4-Methyl-2-pentanone & MW194 & 10 & & ug/L & $U$ & $12 / 19 / 2007$ & $12 / 27 / 2007$ & 10 \\
\hline $8260 B$ & VOA & 4-Methyl-2-pentanone & MW197 & 10 & & $\mathrm{ug} / \mathrm{L}$ & $U$ & $12 / 19 / 2007$ & $12 / 27 / 2007$ & 10 \\
\hline $8260 B$ & VOA & 4-Methyl-2-pentanone & MW236 & 10 & & $\mathrm{ug} / \mathrm{L}$ & $\mathrm{U}$ & $12 / 19 / 2007$ & $12 / 27 / 2007$ & 10 \\
\hline $8260 B$ & VOA & 4-Methyl-2-pentanone & MW242 & 10 & & $\mathrm{ug} / \mathrm{L}$ & $U$ & $12 / 19 / 2007$ & $12 / 27 / 2007$ & 10 \\
\hline $8260 B$ & VOA & 4-Methyl-2-pentanone & MW243 & 50 & & $\mathrm{ug} / \mathrm{L}$ & $U$ & $12 / 19 / 2007$ & $12 / 27 / 2007$ & 50 \\
\hline $8260 \mathrm{~B}$ & VOA & 4-Methyl-2-pentanone & MW262 & 100 & & $\mathrm{ug} / \mathrm{L}$ & $U$ & $12 / 19 / 2007$ & $12 / 27 / 2007$ & 100 \\
\hline $8260 B$ & VOA & 4-Methyl-2-pentanone & MW340 & 800 & & $\mathrm{ug} / \mathrm{L}$ & $U$ & $12 / 19 / 2007$ & $12 / 27 / 2007$ & 800 \\
\hline $8260 B$ & VOA & 4-Methyl-2-pentanone & MW381 & 10 & & $\mathrm{ug} / \mathrm{L}$ & $U$ & $12 / 19 / 2007$ & $12 / 27 / 2007$ & 10 \\
\hline $8260 B$ & VOA & 4-Methyl-2-pentanone & MW66 & 50 & & $\mathrm{ug} / \mathrm{L}$ & $U$ & $12 / 19 / 2007$ & $12 / 27 / 2007$ & 50 \\
\hline $8260 B$ & VOA & 4-Methyl-2-pentanone & QC & 10 & & $\mathrm{ug} / \mathrm{L}$ & $U$ & $12 / 19 / 2007$ & $12 / 27 / 2007$ & 10 \\
\hline $8260 B$ & VOA & 4-Methyl-2-pentanone & QC & 10 & & $\mathrm{ug} / \mathrm{L}$ & $U$ & $12 / 19 / 2007$ & $12 / 27 / 2007$ & 10 \\
\hline $8260 B$ & VOA & Acetone & MW125 & 50 & & ug/L & JU & $12 / 19 / 2007$ & $12 / 27 / 2007$ & 50 \\
\hline $8260 B$ & VOA & Acetone & MW168 & 12 & & $\mathrm{ug} / \mathrm{L}$ & JU & $12 / 19 / 2007$ & $12 / 27 / 2007$ & 12 \\
\hline $8260 B$ & VOA & Acetone & MW185 & 250 & & $\mathrm{ug} / \mathrm{L}$ & JU & $12 / 19 / 2007$ & $12 / 27 / 2007$ & 250 \\
\hline $8260 B$ & VOA & Acetone & MW194 & 10 & & ug/L & JU & $12 / 19 / 2007$ & $12 / 27 / 2007$ & 10 \\
\hline 8260B & VOA & Acetone & MW197 & 10 & & $\mathrm{ug} / \mathrm{L}$ & JU & $12 / 19 / 2007$ & $12 / 27 / 2007$ & 10 \\
\hline $8260 \mathrm{~B}$ & VOA & Acetone & MW236 & 10 & & $\mathrm{ug} / \mathrm{L}$ & JU & $12 / 19 / 2007$ & $12 / 27 / 2007$ & 10 \\
\hline $8260 B$ & VOA & Acetone & MW242 & 10 & & $\mathrm{ug} / \mathrm{L}$ & JU & $12 / 19 / 2007$ & $12 / 27 / 2007$ & 10 \\
\hline $8260 B$ & VOA & Acetone & MW243 & 50 & & ug/L & JU & $12 / 19 / 2007$ & $12 / 27 / 2007$ & 50 \\
\hline $8260 B$ & VOA & Acetone & MW262 & 100 & & ug/L & JU & $12 / 19 / 2007$ & $12 / 27 / 2007$ & 100 \\
\hline $8260 B$ & VOA & Acetone & MW340 & 800 & & ug/L & JU & $12 / 19 / 2007$ & $12 / 27 / 2007$ & 800 \\
\hline $8260 B$ & VOA & Acetone & MW381 & 10 & & $\mathrm{ug} / \mathrm{L}$ & JU & $12 / 19 / 2007$ & $12 / 27 / 2007$ & 10 \\
\hline $8260 B$ & VOA & Acetone & MW66 & 50 & & $u g / L$ & JU & $12 / 19 / 2007$ & $12 / 27 / 2007$ & 50 \\
\hline $8260 B$ & VOA & Acetone & QC & 10 & & ug/L & JU & $12 / 19 / 2007$ & $12 / 27 / 2007$ & 10 \\
\hline $8260 B$ & VOA & Acetone & QC & 10 & & $\mathrm{ug} / \mathrm{L}$ & JU & $12 / 19 / 2007$ & $12 / 27 / 2007$ & 10 \\
\hline $8260 B$ & VOA & Benzene & MW125 & 25 & & $\mathrm{ug} / \mathrm{L}$ & $U$ & $12 / 19 / 2007$ & $12 / 27 / 2007$ & 25 \\
\hline $8260 \mathrm{~B}$ & VOA & Benzene & MW168 & 6.2 & & ug/L & $\mathrm{U}$ & $12 / 19 / 2007$ & $12 / 27 / 2007$ & 6.2 \\
\hline $8260 B$ & VOA & Benzene & MW185 & 120 & & $\mathrm{ug} / \mathrm{L}$ & $U$ & $12 / 19 / 2007$ & $12 / 27 / 2007$ & 120 \\
\hline $8260 B$ & VOA & Benzene & MW194 & 5 & & $\mathrm{ug} / \mathrm{L}$ & $U$ & $12 / 19 / 2007$ & $12 / 27 / 2007$ & 5 \\
\hline $8260 B$ & VOA & Benzene & MW197 & 5 & & ug/L & $U$ & $12 / 19 / 2007$ & $12 / 27 / 2007$ & 5 \\
\hline $8260 B$ & VOA & Benzene & MW236 & 5 & & ug/L & $U$ & $12 / 19 / 2007$ & $12 / 27 / 2007$ & 5 \\
\hline $8260 B$ & VOA & Benzene & MW242 & 5 & & ug/L & $U$ & $12 / 19 / 2007$ & $12 / 27 / 2007$ & 5 \\
\hline $8260 B$ & VOA & Benzene & MW243 & 25 & & $\mathrm{ug} / \mathrm{L}$ & $U$ & $12 / 19 / 2007$ & $12 / 27 / 2007$ & 25 \\
\hline $8260 B$ & VOA & Benzene & MW262 & 50 & & ug/L & $U$ & $12 / 19 / 2007$ & $12 / 27 / 2007$ & 50 \\
\hline 8260B & VOA & Benzene & MW340 & 400 & & $\mathrm{ug} / \mathrm{L}$ & $U$ & $12 / 19 / 2007$ & $12 / 27 / 2007$ & 400 \\
\hline $8260 B$ & VOA & Benzene & MW381 & 5 & & $\mathrm{ug} / \mathrm{L}$ & $\mathrm{U}$ & $12 / 19 / 2007$ & $12 / 27 / 2007$ & 5 \\
\hline $8260 B$ & VOA & Benzene & MW66 & 25 & & $\mathrm{ug} / \mathrm{L}$ & $U$ & $12 / 19 / 2007$ & $12 / 27 / 2007$ & 25 \\
\hline $8260 B$ & VOA & Benzene & QC & 5 & & $\mathrm{ug} / \mathrm{L}$ & $\mathrm{U}$ & $12 / 19 / 2007$ & $12 / 27 / 2007$ & 5 \\
\hline 8260B & VOA & Benzene & QC & 5 & & $\mathrm{ug} / \mathrm{L}$ & $U$ & $12 / 19 / 2007$ & $12 / 27 / 2007$ & 5 \\
\hline $8260 B$ & VOA & Bromodichloromethane & MW125 & 25 & & $\mathrm{ug} / \mathrm{L}$ & $\mathrm{U}$ & $12 / 19 / 2007$ & $12 / 27 / 2007$ & 25 \\
\hline 8260B & VOA & Bromodichloromethane & MW168 & 6.2 & & $\mathrm{ug} / \mathrm{L}$ & $U$ & $12 / 19 / 2007$ & $12 / 27 / 2007$ & 6.2 \\
\hline $8260 B$ & VOA & Bromodichloromethane & MW185 & 120 & & ug/L & $U$ & $12 / 19 / 2007$ & $12 / 27 / 2007$ & 120 \\
\hline $8260 B$ & VOA & Bromodichloromethane & MW194 & 5 & & $\mathrm{ug} / \mathrm{L}$ & $U$ & $12 / 19 / 2007$ & $12 / 27 / 2007$ & 5 \\
\hline $8260 \mathrm{~B}$ & VOA & Bromodichloromethane & MW197 & 5 & & $\mathrm{ug} / \mathrm{L}$ & $\mathrm{U}$ & $12 / 19 / 2007$ & $12 / 27 / 2007$ & 5 \\
\hline 8260B & VOA & Bromodichloromethane & MW236 & 5 & & $\mathrm{ug} / \mathrm{L}$ & $U$ & $12 / 19 / 2007$ & $12 / 27 / 2007$ & 5 \\
\hline $8260 \mathrm{~B}$ & VOA & Bromodichloromethane & MW242 & 5 & & $\mathrm{ug} / \mathrm{L}$ & $U$ & $12 / 19 / 2007$ & $12 / 27 / 2007$ & 5 \\
\hline $8260 B$ & VOA & Bromodichloromethane & MW243 & 25 & & $\mathrm{ug} / \mathrm{L}$ & $\mathrm{U}$ & $12 / 19 / 2007$ & $12 / 27 / 2007$ & 25 \\
\hline $8260 B$ & VOA & Bromodichloromethane & MW262 & 50 & & $\mathrm{ug} / \mathrm{L}$ & $U$ & $12 / 19 / 2007$ & $12 / 27 / 2007$ & 50 \\
\hline $8260 \mathrm{~B}$ & VOA & Bromodichloromethane & MW340 & 400 & & $\mathrm{ug} / \mathrm{L}$ & $U$ & $12 / 19 / 2007$ & $12 / 27 / 2007$ & 400 \\
\hline 8260B & VOA & Bromodichloromethane & MW381 & 5 & & $\mathrm{ug} / \mathrm{L}$ & $U$ & $12 / 19 / 2007$ & $12 / 27 / 2007$ & 5 \\
\hline $8260 \mathrm{~B}$ & VOA & Bromodichloromethane & MW66 & 25 & & $\mathrm{ug} / \mathrm{L}$ & $U$ & $12 / 19 / 2007$ & $12 / 27 / 2007$ & 25 \\
\hline $8260 B$ & VOA & Bromodichloromethane & QC & 5 & & $\mathrm{ug} / \mathrm{L}$ & $U$ & $12 / 19 / 2007$ & $12 / 27 / 2007$ & 5 \\
\hline $8260 B$ & VOA & Bromodichloromethane & QC & 5 & & $\mathrm{ug} / \mathrm{L}$ & $U$ & $12 / 19 / 2007$ & $12 / 27 / 2007$ & 5 \\
\hline 8260B & VOA & Bromoform & MW125 & 25 & & $\mathrm{ug} / \mathrm{L}$ & $U$ & $12 / 19 / 2007$ & $12 / 27 / 2007$ & 25 \\
\hline 8260B & VOA & Bromoform & MW168 & 6.2 & & $\mathrm{ug} / \mathrm{L}$ & $U$ & $12 / 19 / 2007$ & $12 / 27 / 2007$ & 6.2 \\
\hline 8260B & VOA & Bromoform & MW185 & 120 & & $\mathrm{ug} / \mathrm{L}$ & $U$ & $12 / 19 / 2007$ & $12 / 27 / 2007$ & 120 \\
\hline $8260 B$ & VOA & Bromoform & MW194 & 5 & & $\mathrm{ug} / \mathrm{L}$ & $U$ & $12 / 19 / 2007$ & $12 / 27 / 2007$ & 5 \\
\hline
\end{tabular}




\begin{tabular}{|c|c|c|c|c|c|c|c|c|c|c|}
\hline Method & AnaType & Chemical Name & Station & Result & Error & Units & Qualifier & $\begin{array}{c}\text { Date } \\
\text { Collected }\end{array}$ & $\begin{array}{c}\text { Date } \\
\text { Analyzed }\end{array}$ & $\begin{array}{l}\text { Detection } \\
\text { Limit }\end{array}$ \\
\hline $8260 B$ & VOA & Bromoform & MW197 & 5 & & ug/L & $U$ & $12 / 19 / 2007$ & $12 / 27 / 2007$ & 5 \\
\hline $8260 B$ & VOA & Bromoform & MW236 & 5 & & ug/L & $\mathrm{U}$ & $12 / 19 / 2007$ & $12 / 27 / 2007$ & 5 \\
\hline $8260 B$ & VOA & Bromoform & MW242 & 5 & & $\mathrm{ug} / \mathrm{L}$ & $U$ & $12 / 19 / 2007$ & $12 / 27 / 2007$ & 5 \\
\hline $8260 B$ & VOA & Bromoform & MW243 & 25 & & $\mathrm{ug} / \mathrm{L}$ & $U$ & $12 / 19 / 2007$ & $12 / 27 / 2007$ & 25 \\
\hline $8260 B$ & VOA & Bromoform & MW262 & 50 & & $\mathrm{ug} / \mathrm{L}$ & $U$ & $12 / 19 / 2007$ & $12 / 27 / 2007$ & 50 \\
\hline $8260 B$ & VOA & Bromoform & MW340 & 400 & & $\mathrm{ug} / \mathrm{L}$ & $\mathrm{U}$ & $12 / 19 / 2007$ & $12 / 27 / 2007$ & 400 \\
\hline $8260 B$ & VOA & Bromoform & MW381 & 5 & & $\mathrm{ug} / \mathrm{L}$ & $\mathrm{U}$ & $12 / 19 / 2007$ & $12 / 27 / 2007$ & 5 \\
\hline $8260 \mathrm{~B}$ & VOA & Bromoform & MW66 & 25 & & $\mathrm{ug} / \mathrm{L}$ & $\mathrm{U}$ & $12 / 19 / 2007$ & $12 / 27 / 2007$ & 25 \\
\hline $8260 B$ & VOA & Bromoform & QC & 5 & & $\mathrm{ug} / \mathrm{L}$ & $U$ & $12 / 19 / 2007$ & $12 / 27 / 2007$ & 5 \\
\hline $8260 B$ & VOA & Bromoform & QC & 5 & & $\mathrm{ug} / \mathrm{L}$ & $U$ & $12 / 19 / 2007$ & $12 / 27 / 2007$ & 5 \\
\hline $8260 B$ & VOA & Bromomethane & MW125 & 25 & & $\mathrm{ug} / \mathrm{L}$ & $\mathrm{U}$ & $12 / 19 / 2007$ & $12 / 27 / 2007$ & 25 \\
\hline $8260 \mathrm{~B}$ & VOA & Bromomethane & MW168 & 6.2 & & $\mathrm{ug} / \mathrm{L}$ & $\mathrm{U}$ & $12 / 19 / 2007$ & $12 / 27 / 2007$ & 6.2 \\
\hline $8260 B$ & VOA & Bromomethane & MW185 & 120 & & $\mathrm{ug} / \mathrm{L}$ & $\mathrm{U}$ & $12 / 19 / 2007$ & $12 / 27 / 2007$ & 120 \\
\hline $8260 B$ & VOA & Bromomethane & MW194 & 5 & & $\mathrm{ug} / \mathrm{L}$ & $U$ & $12 / 19 / 2007$ & $12 / 27 / 2007$ & 5 \\
\hline $8260 B$ & VOA & Bromomethane & MW197 & 5 & & $\mathrm{ug} / \mathrm{L}$ & $U$ & $12 / 19 / 2007$ & $12 / 27 / 2007$ & 5 \\
\hline $8260 B$ & VOA & Bromomethane & MW236 & 5 & & $\mathrm{ug} / \mathrm{L}$ & $U$ & $12 / 19 / 2007$ & $12 / 27 / 2007$ & 5 \\
\hline $8260 B$ & VOA & Bromomethane & MW242 & 5 & & $\mathrm{ug} / \mathrm{L}$ & $U$ & $12 / 19 / 2007$ & $12 / 27 / 2007$ & 5 \\
\hline $8260 B$ & VOA & Bromomethane & MW243 & 25 & & $\mathrm{ug} / \mathrm{L}$ & $U$ & $12 / 19 / 2007$ & $12 / 27 / 2007$ & 25 \\
\hline $8260 B$ & VOA & Bromomethane & MW262 & 50 & & $\mathrm{ug} / \mathrm{L}$ & $U$ & $12 / 19 / 2007$ & $12 / 27 / 2007$ & 50 \\
\hline $8260 B$ & VOA & Bromomethane & MW340 & 400 & & $\mathrm{ug} / \mathrm{L}$ & $U$ & $12 / 19 / 2007$ & $12 / 27 / 2007$ & 400 \\
\hline $8260 B$ & VOA & Bromomethane & MW381 & 5 & & $\mathrm{ug} / \mathrm{L}$ & U & $12 / 19 / 2007$ & $12 / 27 / 2007$ & 5 \\
\hline $8260 B$ & VOA & Bromomethane & MW66 & 25 & & $\mathrm{ug} / \mathrm{L}$ & $U$ & $12 / 19 / 2007$ & $12 / 27 / 2007$ & 25 \\
\hline $8260 B$ & VOA & Bromomethane & $\mathrm{QC}$ & 5 & & $\mathrm{ug} / \mathrm{L}$ & $U$ & $12 / 19 / 2007$ & $12 / 27 / 2007$ & 5 \\
\hline $8260 B$ & VOA & Bromomethane & QC & 5 & & $\mathrm{ug} / \mathrm{L}$ & $U$ & $12 / 19 / 2007$ & $12 / 27 / 2007$ & 5 \\
\hline $8260 B$ & VOA & Carbon disulfide & MW125 & 25 & & $\mathrm{ug} / \mathrm{L}$ & $U$ & $12 / 19 / 2007$ & $12 / 27 / 2007$ & 25 \\
\hline $8260 B$ & VOA & Carbon disulfide & MW168 & 6.2 & & $\mathrm{ug} / \mathrm{L}$ & $\mathrm{U}$ & $12 / 19 / 2007$ & $12 / 27 / 2007$ & 6.2 \\
\hline $8260 \mathrm{~B}$ & VOA & Carbon disulfide & MW185 & 120 & & $\mathrm{ug} / \mathrm{L}$ & $\mathrm{U}$ & $12 / 19 / 2007$ & $12 / 27 / 2007$ & 120 \\
\hline $8260 B$ & VOA & Carbon disulfide & MW194 & 5 & & $\mathrm{ug} / \mathrm{L}$ & $\mathrm{U}$ & $12 / 19 / 2007$ & $12 / 27 / 2007$ & 5 \\
\hline $8260 B$ & VOA & Carbon disulfide & MW197 & 5 & & $\mathrm{ug} / \mathrm{L}$ & $U$ & $12 / 19 / 2007$ & $12 / 27 / 2007$ & 5 \\
\hline $8260 B$ & VOA & Carbon disulfide & MW236 & 5 & & $\mathrm{ug} / \mathrm{L}$ & $\mathrm{U}$ & $12 / 19 / 2007$ & $12 / 27 / 2007$ & 5 \\
\hline $8260 B$ & VOA & Carbon disulfide & MW242 & 5 & & $\mathrm{ug} / \mathrm{L}$ & $U$ & $12 / 19 / 2007$ & $12 / 27 / 2007$ & 5 \\
\hline $8260 \mathrm{~B}$ & VOA & Carbon disulfide & MW243 & 25 & & $\mathrm{ug} / \mathrm{L}$ & U & $12 / 19 / 2007$ & $12 / 27 / 2007$ & 25 \\
\hline $8260 B$ & VOA & Carbon disulfide & MW262 & 50 & & $\mathrm{ug} / \mathrm{L}$ & $U$ & $12 / 19 / 2007$ & $12 / 27 / 2007$ & 50 \\
\hline $8260 B$ & VOA & Carbon disulfide & MW340 & 400 & & $\mathrm{ug} / \mathrm{L}$ & $U$ & $12 / 19 / 2007$ & $12 / 27 / 2007$ & 400 \\
\hline $8260 B$ & VOA & Carbon disulfide & MW381 & 5 & & $\mathrm{ug} / \mathrm{L}$ & $U$ & $12 / 19 / 2007$ & $12 / 27 / 2007$ & 5 \\
\hline $8260 B$ & VOA & Carbon disulfide & MW66 & 25 & & $\mathrm{ug} / \mathrm{L}$ & $U$ & $12 / 19 / 2007$ & $12 / 27 / 2007$ & 25 \\
\hline $8260 B$ & VOA & Carbon disulfide & $\mathrm{QC}$ & 5 & & $\mathrm{ug} / \mathrm{L}$ & $U$ & $12 / 19 / 2007$ & $12 / 27 / 2007$ & 5 \\
\hline $8260 B$ & VOA & Carbon disulfide & QC & 5 & & $\mathrm{ug} / \mathrm{L}$ & $U$ & $12 / 19 / 2007$ & $12 / 27 / 2007$ & 5 \\
\hline $8260 B$ & VOA & Carbon tetrachloride & MW125 & 25 & & $\mathrm{ug} / \mathrm{L}$ & $U$ & $12 / 19 / 2007$ & $12 / 27 / 2007$ & 25 \\
\hline $8260 B$ & VOA & Carbon tetrachloride & MW168 & 6.2 & & $\mathrm{ug} / \mathrm{L}$ & $U$ & $12 / 19 / 2007$ & $12 / 27 / 2007$ & 6.2 \\
\hline $8260 B$ & VOA & Carbon tetrachloride & MW185 & 120 & & $\mathrm{ug} / \mathrm{L}$ & $U$ & $12 / 19 / 2007$ & $12 / 27 / 2007$ & 120 \\
\hline $8260 B$ & VOA & Carbon tetrachloride & MW194 & 5 & & $\mathrm{ug} / \mathrm{L}$ & $U$ & $12 / 19 / 2007$ & $12 / 27 / 2007$ & 5 \\
\hline $8260 B$ & VOA & Carbon tetrachloride & MW197 & 5 & & $\mathrm{ug} / \mathrm{L}$ & $\mathrm{U}$ & $12 / 19 / 2007$ & $12 / 27 / 2007$ & 5 \\
\hline $8260 B$ & VOA & Carbon tetrachloride & MW236 & 5 & & $\mathrm{ug} / \mathrm{L}$ & $U$ & $12 / 19 / 2007$ & $12 / 27 / 2007$ & 5 \\
\hline $8260 \mathrm{~B}$ & VOA & Carbon tetrachloride & MW242 & 5 & & $\mathrm{ug} / \mathrm{L}$ & $\mathrm{U}$ & $12 / 19 / 2007$ & $12 / 27 / 2007$ & 5 \\
\hline $8260 B$ & VOA & Carbon tetrachloride & MW243 & 25 & & ug/L & $U$ & $12 / 19 / 2007$ & $12 / 27 / 2007$ & 25 \\
\hline $8260 B$ & VOA & Carbon tetrachloride & MW262 & 50 & & $\mathrm{ug} / \mathrm{L}$ & $\mathrm{U}$ & $12 / 19 / 2007$ & $12 / 27 / 2007$ & 50 \\
\hline $8260 B$ & VOA & Carbon tetrachloride & MW340 & 400 & & $\mathrm{ug} / \mathrm{L}$ & $U$ & $12 / 19 / 2007$ & $12 / 27 / 2007$ & 400 \\
\hline $8260 B$ & VOA & Carbon tetrachloride & MW381 & 5 & & ug/L & $\mathrm{U}$ & $12 / 19 / 2007$ & $12 / 27 / 2007$ & 5 \\
\hline $8260 B$ & VOA & Carbon tetrachloride & MW66 & 25 & & $\mathrm{ug} / \mathrm{L}$ & $U$ & $12 / 19 / 2007$ & $12 / 27 / 2007$ & 25 \\
\hline $8260 B$ & VOA & Carbon tetrachloride & $\mathrm{QC}$ & 5 & & ug/L & $U$ & $12 / 19 / 2007$ & $12 / 27 / 2007$ & 5 \\
\hline $8260 B$ & VOA & Carbon tetrachloride & QC & 5 & & $\mathrm{ug} / \mathrm{L}$ & $U$ & $12 / 19 / 2007$ & $12 / 27 / 2007$ & 5 \\
\hline $8260 B$ & VOA & Chlorobenzene & MW125 & 25 & & $\mathrm{ug} / \mathrm{L}$ & $U$ & $12 / 19 / 2007$ & $12 / 27 / 2007$ & 25 \\
\hline $8260 B$ & VOA & Chlorobenzene & MW168 & 6.2 & & $\mathrm{ug} / \mathrm{L}$ & $U$ & $12 / 19 / 2007$ & $12 / 27 / 2007$ & 6.2 \\
\hline $8260 B$ & VOA & Chlorobenzene & MW185 & 120 & & ug/L & $U$ & $12 / 19 / 2007$ & $12 / 27 / 2007$ & 120 \\
\hline $8260 B$ & VOA & Chlorobenzene & MW194 & 5 & & ug/L & $\mathrm{U}$ & $12 / 19 / 2007$ & $12 / 27 / 2007$ & 5 \\
\hline $8260 B$ & VOA & Chlorobenzene & MW197 & 5 & & ug/L & $U$ & $12 / 19 / 2007$ & $12 / 27 / 2007$ & 5 \\
\hline $8260 B$ & VOA & Chlorobenzene & MW236 & 5 & & $\mathrm{ug} / \mathrm{L}$ & $U$ & $12 / 19 / 2007$ & $12 / 27 / 2007$ & 5 \\
\hline $8260 B$ & VOA & Chlorobenzene & MW242 & 5 & & $\mathrm{ug} / \mathrm{L}$ & U & $12 / 19 / 2007$ & $12 / 27 / 2007$ & 5 \\
\hline $8260 \mathrm{~B}$ & VOA & Chlorobenzene & MW243 & 25 & & $\mathrm{ug} / \mathrm{L}$ & $U$ & $12 / 19 / 2007$ & $12 / 27 / 2007$ & 25 \\
\hline $8260 B$ & VOA & Chlorobenzene & MW262 & 50 & & $\mathrm{ug} / \mathrm{L}$ & $U$ & $12 / 19 / 2007$ & $12 / 27 / 2007$ & 50 \\
\hline $8260 B$ & VOA & Chlorobenzene & MW340 & 400 & & $\mathrm{ug} / \mathrm{L}$ & U & $12 / 19 / 2007$ & $12 / 27 / 2007$ & 400 \\
\hline $8260 B$ & VOA & Chlorobenzene & MW381 & 5 & & $\mathrm{ug} / \mathrm{L}$ & $U$ & $12 / 19 / 2007$ & $12 / 27 / 2007$ & 5 \\
\hline $8260 B$ & VOA & Chlorobenzene & MW66 & 25 & & $\mathrm{ug} / \mathrm{L}$ & $\mathrm{U}$ & $12 / 19 / 2007$ & $12 / 27 / 2007$ & 25 \\
\hline $8260 B$ & VOA & Chlorobenzene & QC & 5 & & $\mathrm{ug} / \mathrm{L}$ & U & $12 / 19 / 2007$ & $12 / 27 / 2007$ & 5 \\
\hline $8260 B$ & VOA & Chlorobenzene & $\mathrm{QC}$ & 5 & & $\mathrm{ug} / \mathrm{L}$ & $\mathrm{U}$ & $12 / 19 / 2007$ & $12 / 27 / 2007$ & 5 \\
\hline $8260 B$ & VOA & Chloroethane & MW125 & 25 & & $\mathrm{ug} / \mathrm{L}$ & U & $12 / 19 / 2007$ & $12 / 27 / 2007$ & 25 \\
\hline $8260 B$ & VOA & Chloroethane & MW168 & 6.2 & & $\mathrm{ug} / \mathrm{L}$ & $U$ & $12 / 19 / 2007$ & $12 / 27 / 2007$ & 6.2 \\
\hline $8260 B$ & VOA & Chloroethane & MW185 & 120 & & $\mathrm{ug} / \mathrm{L}$ & $\mathrm{U}$ & $12 / 19 / 2007$ & $12 / 27 / 2007$ & 120 \\
\hline $8260 B$ & VOA & Chloroethane & MW194 & 5 & & $\mathrm{ug} / \mathrm{L}$ & U & $12 / 19 / 2007$ & $12 / 27 / 2007$ & 5 \\
\hline $8260 B$ & VOA & Chloroethane & MW197 & 5 & & ug/L & $\mathrm{U}$ & $12 / 19 / 2007$ & $12 / 27 / 2007$ & 5 \\
\hline
\end{tabular}




\begin{tabular}{|c|c|c|c|c|c|c|c|c|c|c|}
\hline Method & AnaType & Chemical Name & Station & Result & Error & Units & Qualifier & $\begin{array}{c}\text { Date } \\
\text { Collected }\end{array}$ & $\begin{array}{c}\text { Date } \\
\text { Analyzed }\end{array}$ & $\begin{array}{l}\text { Detection } \\
\text { Limit }\end{array}$ \\
\hline $8260 B$ & VOA & Chloroethane & MW236 & 5 & & ug/L & $U$ & $12 / 19 / 2007$ & $12 / 27 / 2007$ & 5 \\
\hline $8260 B$ & VOA & Chloroethane & MW242 & 5 & & ug/L & $\mathrm{U}$ & $12 / 19 / 2007$ & $12 / 27 / 2007$ & 5 \\
\hline $8260 B$ & VOA & Chloroethane & MW243 & 25 & & $\mathrm{ug} / \mathrm{L}$ & $U$ & $12 / 19 / 2007$ & $12 / 27 / 2007$ & 25 \\
\hline $8260 \mathrm{~B}$ & VOA & Chloroethane & MW262 & 50 & & $\mathrm{ug} / \mathrm{L}$ & $U$ & $12 / 19 / 2007$ & $12 / 27 / 2007$ & 50 \\
\hline $8260 B$ & VOA & Chloroethane & MW340 & 400 & & $\mathrm{ug} / \mathrm{L}$ & $U$ & $12 / 19 / 2007$ & $12 / 27 / 2007$ & 400 \\
\hline $8260 B$ & VOA & Chloroethane & MW381 & 5 & & $\mathrm{ug} / \mathrm{L}$ & $\mathrm{U}$ & $12 / 19 / 2007$ & $12 / 27 / 2007$ & 5 \\
\hline $8260 B$ & VOA & Chloroethane & MW66 & 25 & & $\mathrm{ug} / \mathrm{L}$ & $\mathrm{U}$ & $12 / 19 / 2007$ & $12 / 27 / 2007$ & 25 \\
\hline $8260 \mathrm{~B}$ & VOA & Chloroethane & $\mathrm{QC}$ & 5 & & $\mathrm{ug} / \mathrm{L}$ & $\mathrm{U}$ & $12 / 19 / 2007$ & $12 / 27 / 2007$ & 5 \\
\hline $8260 B$ & VOA & Chloroethane & $\mathrm{QC}$ & 5 & & $\mathrm{ug} / \mathrm{L}$ & $U$ & $12 / 19 / 2007$ & $12 / 27 / 2007$ & 5 \\
\hline $8260 B$ & VOA & Chloroform & MW125 & 25 & & $\mathrm{ug} / \mathrm{L}$ & $U$ & $12 / 19 / 2007$ & $12 / 27 / 2007$ & 25 \\
\hline $8260 B$ & VOA & Chloroform & MW168 & 6.2 & & $\mathrm{ug} / \mathrm{L}$ & $\mathrm{U}$ & $12 / 19 / 2007$ & $12 / 27 / 2007$ & 6.2 \\
\hline $8260 B$ & VOA & Chloroform & MW185 & 120 & & $\mathrm{ug} / \mathrm{L}$ & $\mathrm{U}$ & $12 / 19 / 2007$ & $12 / 27 / 2007$ & 120 \\
\hline $8260 B$ & VOA & Chloroform & MW194 & 5 & & $\mathrm{ug} / \mathrm{L}$ & $\mathrm{U}$ & $12 / 19 / 2007$ & $12 / 27 / 2007$ & 5 \\
\hline $8260 B$ & VOA & Chloroform & MW197 & 5 & & $\mathrm{ug} / \mathrm{L}$ & $U$ & $12 / 19 / 2007$ & $12 / 27 / 2007$ & 5 \\
\hline $8260 B$ & VOA & Chloroform & MW236 & 5 & & $\mathrm{ug} / \mathrm{L}$ & $U$ & $12 / 19 / 2007$ & $12 / 27 / 2007$ & 5 \\
\hline $8260 B$ & VOA & Chloroform & MW242 & 5 & & $\mathrm{ug} / \mathrm{L}$ & $U$ & $12 / 19 / 2007$ & $12 / 27 / 2007$ & 5 \\
\hline $8260 B$ & VOA & Chloroform & MW243 & 25 & & $\mathrm{ug} / \mathrm{L}$ & $U$ & $12 / 19 / 2007$ & $12 / 27 / 2007$ & 25 \\
\hline $8260 B$ & VOA & Chloroform & MW262 & 50 & & $\mathrm{ug} / \mathrm{L}$ & $U$ & $12 / 19 / 2007$ & $12 / 27 / 2007$ & 50 \\
\hline $8260 B$ & VOA & Chloroform & MW340 & 400 & & ug/L & $U$ & $12 / 19 / 2007$ & $12 / 27 / 2007$ & 400 \\
\hline $8260 B$ & VOA & Chloroform & MW381 & 5 & & $\mathrm{ug} / \mathrm{L}$ & $U$ & $12 / 19 / 2007$ & $12 / 27 / 2007$ & 5 \\
\hline $8260 B$ & VOA & Chloroform & MW66 & 25 & & $\mathrm{ug} / \mathrm{L}$ & $U$ & $12 / 19 / 2007$ & $12 / 27 / 2007$ & 25 \\
\hline $8260 B$ & VOA & Chloroform & QC & 5 & & $\mathrm{ug} / \mathrm{L}$ & $U$ & $12 / 19 / 2007$ & $12 / 27 / 2007$ & 5 \\
\hline $8260 B$ & VOA & Chloroform & $\mathrm{QC}$ & 5 & & $\mathrm{ug} / \mathrm{L}$ & $\mathrm{U}$ & $12 / 19 / 2007$ & $12 / 27 / 2007$ & 5 \\
\hline $8260 B$ & VOA & Chloromethane & MW125 & 25 & & $\mathrm{ug} / \mathrm{L}$ & $U$ & $12 / 19 / 2007$ & $12 / 27 / 2007$ & 25 \\
\hline $8260 B$ & VOA & Chloromethane & MW168 & 6.2 & & $\mathrm{ug} / \mathrm{L}$ & $U$ & $12 / 19 / 2007$ & $12 / 27 / 2007$ & 6.2 \\
\hline $8260 B$ & VOA & Chloromethane & MW185 & 120 & & $\mathrm{ug} / \mathrm{L}$ & $\mathrm{U}$ & $12 / 19 / 2007$ & $12 / 27 / 2007$ & 120 \\
\hline $8260 \mathrm{~B}$ & VOA & Chloromethane & MW194 & 5 & & $\mathrm{ug} / \mathrm{L}$ & $\mathrm{U}$ & $12 / 19 / 2007$ & $12 / 27 / 2007$ & 5 \\
\hline $8260 B$ & VOA & Chloromethane & MW197 & 5 & & $\mathrm{ug} / \mathrm{L}$ & $\mathrm{U}$ & $12 / 19 / 2007$ & $12 / 27 / 2007$ & 5 \\
\hline $8260 B$ & VOA & Chloromethane & MW236 & 5 & & $\mathrm{ug} / \mathrm{L}$ & $U$ & $12 / 19 / 2007$ & $12 / 27 / 2007$ & 5 \\
\hline $8260 B$ & VOA & Chloromethane & MW242 & 5 & & $\mathrm{ug} / \mathrm{L}$ & $\mathrm{U}$ & $12 / 19 / 2007$ & $12 / 27 / 2007$ & 5 \\
\hline $8260 B$ & VOA & Chloromethane & MW243 & 25 & & $\mathrm{ug} / \mathrm{L}$ & $U$ & $12 / 19 / 2007$ & $12 / 27 / 2007$ & 25 \\
\hline $8260 B$ & VOA & Chloromethane & MW262 & 50 & & $\mathrm{ug} / \mathrm{L}$ & $\mathrm{U}$ & $12 / 19 / 2007$ & $12 / 27 / 2007$ & 50 \\
\hline $8260 B$ & VOA & Chloromethane & MW340 & 400 & & $\mathrm{ug} / \mathrm{L}$ & U & $12 / 19 / 2007$ & $12 / 27 / 2007$ & 400 \\
\hline $8260 B$ & VOA & Chloromethane & MW381 & 5 & & $\mathrm{ug} / \mathrm{L}$ & U & $12 / 19 / 2007$ & $12 / 27 / 2007$ & 5 \\
\hline $8260 B$ & VOA & Chloromethane & MW66 & 25 & & $\mathrm{ug} / \mathrm{L}$ & $U$ & $12 / 19 / 2007$ & $12 / 27 / 2007$ & 25 \\
\hline $8260 B$ & VOA & Chloromethane & $\mathrm{QC}$ & 5 & & $\mathrm{ug} / \mathrm{L}$ & $U$ & $12 / 19 / 2007$ & $12 / 27 / 2007$ & 5 \\
\hline $8260 B$ & VOA & Chloromethane & QC & 5 & & $\mathrm{ug} / \mathrm{L}$ & $U$ & $12 / 19 / 2007$ & $12 / 27 / 2007$ & 5 \\
\hline $8260 B$ & VOA & cis-1,2-Dichloroethene & MW125 & 5 & & $\mathrm{ug} / \mathrm{L}$ & $U$ & $12 / 19 / 2007$ & $12 / 27 / 2007$ & 5 \\
\hline $8260 B$ & VOA & cis-1,2-Dichloroethene & MW168 & 1.2 & & $\mathrm{ug} / \mathrm{L}$ & $U$ & $12 / 19 / 2007$ & $12 / 27 / 2007$ & 1.2 \\
\hline $8260 B$ & VOA & cis-1,2-Dichloroethene & MW185 & 76 & & $\mathrm{ug} / \mathrm{L}$ & $\mathrm{D}$ & $12 / 19 / 2007$ & $12 / 27 / 2007$ & 25 \\
\hline $8260 B$ & VOA & cis-1,2-Dichloroethene & MW194 & 1 & & $\mathrm{ug} / \mathrm{L}$ & $U$ & $12 / 19 / 2007$ & $12 / 27 / 2007$ & 1 \\
\hline $8260 B$ & VOA & cis-1,2-Dichloroethene & MW197 & 1 & & $\mathrm{ug} / \mathrm{L}$ & $U$ & $12 / 19 / 2007$ & $12 / 27 / 2007$ & 1 \\
\hline $8260 B$ & VOA & cis-1,2-Dichloroethene & MW236 & 1 & & $\mathrm{ug} / \mathrm{L}$ & $\mathrm{U}$ & $12 / 19 / 2007$ & $12 / 27 / 2007$ & 1 \\
\hline $8260 B$ & VOA & cis-1,2-Dichloroethene & MW242 & 4.4 & & $\mathrm{ug} / \mathrm{L}$ & & $12 / 19 / 2007$ & $12 / 27 / 2007$ & 1 \\
\hline $8260 \mathrm{~B}$ & VOA & cis-1,2-Dichloroethene & MW243 & 5 & & $\mathrm{ug} / \mathrm{L}$ & $\mathrm{U}$ & $12 / 19 / 2007$ & $12 / 27 / 2007$ & 5 \\
\hline $8260 B$ & VOA & cis-1,2-Dichloroethene & MW262 & 11 & & $\mathrm{ug} / \mathrm{L}$ & $\mathrm{D}$ & $12 / 19 / 2007$ & $12 / 27 / 2007$ & 10 \\
\hline $8260 B$ & VOA & cis-1,2-Dichloroethene & MW340 & 80 & & $\mathrm{ug} / \mathrm{L}$ & $\mathrm{U}$ & $12 / 19 / 2007$ & $12 / 27 / 2007$ & 80 \\
\hline $8260 B$ & VOA & cis-1,2-Dichloroethene & MW381 & 1 & & $\mathrm{ug} / \mathrm{L}$ & $U$ & $12 / 19 / 2007$ & $12 / 27 / 2007$ & 1 \\
\hline $8260 B$ & VOA & cis-1,2-Dichloroethene & MW66 & 5 & & $\mathrm{ug} / \mathrm{L}$ & $\mathrm{U}$ & $12 / 19 / 2007$ & $12 / 27 / 2007$ & 5 \\
\hline $8260 B$ & VOA & cis-1,2-Dichloroethene & QC & 1 & & $\mathrm{ug} / \mathrm{L}$ & $U$ & $12 / 19 / 2007$ & $12 / 27 / 2007$ & 1 \\
\hline $8260 B$ & VOA & cis-1,2-Dichloroethene & QC & 1 & & $\mathrm{ug} / \mathrm{L}$ & $U$ & $12 / 19 / 2007$ & $12 / 27 / 2007$ & 1 \\
\hline $8260 B$ & VOA & cis-1,3-Dichloropropene & MW125 & 25 & & $\mathrm{ug} / \mathrm{L}$ & $U$ & $12 / 19 / 2007$ & $12 / 27 / 2007$ & 25 \\
\hline $8260 B$ & VOA & cis-1,3-Dichloropropene & MW168 & 6.2 & & $\mathrm{ug} / \mathrm{L}$ & $U$ & $12 / 19 / 2007$ & $12 / 27 / 2007$ & 6.2 \\
\hline $8260 B$ & VOA & cis-1,3-Dichloropropene & MW185 & 120 & & $\mathrm{ug} / \mathrm{L}$ & $U$ & $12 / 19 / 2007$ & $12 / 27 / 2007$ & 120 \\
\hline $8260 B$ & VOA & cis-1,3-Dichloropropene & MW194 & 5 & & ug/L & $U$ & $12 / 19 / 2007$ & $12 / 27 / 2007$ & 5 \\
\hline $8260 B$ & VOA & cis-1,3-Dichloropropene & MW197 & 5 & & ug/L & $\mathrm{U}$ & $12 / 19 / 2007$ & $12 / 27 / 2007$ & 5 \\
\hline $8260 B$ & VOA & cis-1,3-Dichloropropene & MW236 & 5 & & $\mathrm{ug} / \mathrm{L}$ & $U$ & $12 / 19 / 2007$ & $12 / 27 / 2007$ & 5 \\
\hline $8260 B$ & VOA & cis-1,3-Dichloropropene & MW242 & 5 & & $\mathrm{ug} / \mathrm{L}$ & $U$ & $12 / 19 / 2007$ & $12 / 27 / 2007$ & 5 \\
\hline $8260 B$ & VOA & cis-1,3-Dichloropropene & MW243 & 25 & & $\mathrm{ug} / \mathrm{L}$ & $\mathrm{U}$ & $12 / 19 / 2007$ & $12 / 27 / 2007$ & 25 \\
\hline $8260 B$ & VOA & cis-1,3-Dichloropropene & MW262 & 50 & & $\mathrm{ug} / \mathrm{L}$ & $U$ & $12 / 19 / 2007$ & $12 / 27 / 2007$ & 50 \\
\hline $8260 B$ & VOA & cis-1,3-Dichloropropene & MW340 & 400 & & $\mathrm{ug} / \mathrm{L}$ & $U$ & $12 / 19 / 2007$ & $12 / 27 / 2007$ & 400 \\
\hline $8260 B$ & VOA & cis-1,3-Dichloropropene & MW381 & 5 & & $\mathrm{ug} / \mathrm{L}$ & $\mathrm{U}$ & $12 / 19 / 2007$ & $12 / 27 / 2007$ & 5 \\
\hline $8260 B$ & VOA & cis-1,3-Dichloropropene & MW66 & 25 & & $\mathrm{ug} / \mathrm{L}$ & $U$ & $12 / 19 / 2007$ & $12 / 27 / 2007$ & 25 \\
\hline $8260 \mathrm{~B}$ & VOA & cis-1,3-Dichloropropene & QC & 5 & & $\mathrm{ug} / \mathrm{L}$ & $\mathrm{U}$ & $12 / 19 / 2007$ & $12 / 27 / 2007$ & 5 \\
\hline $8260 B$ & VOA & cis-1,3-Dichloropropene & QC & 5 & & $\mathrm{ug} / \mathrm{L}$ & $U$ & $12 / 19 / 2007$ & $12 / 27 / 2007$ & 5 \\
\hline $8260 B$ & VOA & Dibromochloromethane & MW125 & 25 & & $\mathrm{ug} / \mathrm{L}$ & $\mathrm{U}$ & $12 / 19 / 2007$ & $12 / 27 / 2007$ & 25 \\
\hline $8260 B$ & VOA & Dibromochloromethane & MW168 & 6.2 & & $\mathrm{ug} / \mathrm{L}$ & $\mathrm{U}$ & $12 / 19 / 2007$ & $12 / 27 / 2007$ & 6.2 \\
\hline $8260 B$ & VOA & Dibromochloromethane & MW185 & 120 & & $\mathrm{ug} / \mathrm{L}$ & $U$ & $12 / 19 / 2007$ & $12 / 27 / 2007$ & 120 \\
\hline $8260 B$ & VOA & Dibromochloromethane & MW194 & 5 & & $\mathrm{ug} / \mathrm{L}$ & $\mathrm{U}$ & $12 / 19 / 2007$ & $12 / 27 / 2007$ & 5 \\
\hline $8260 B$ & VOA & Dibromochloromethane & MW197 & 5 & & $\mathrm{ug} / \mathrm{L}$ & $U$ & $12 / 19 / 2007$ & $12 / 27 / 2007$ & 5 \\
\hline $8260 B$ & VOA & Dibromochloromethane & MW236 & 5 & & $\mathrm{ug} / \mathrm{L}$ & $\mathrm{U}$ & $12 / 19 / 2007$ & $12 / 27 / 2007$ & 5 \\
\hline
\end{tabular}




\begin{tabular}{|c|c|c|}
\hline Method & AnaType & Chemical Name \\
\hline $8260 B$ & VOA & Dibromochloromethane \\
\hline $8260 B$ & VOA & Dibromochloromethane \\
\hline $8260 B$ & VOA & Dibromochloromethane \\
\hline $8260 B$ & VOA & Dibromochloromethane \\
\hline $8260 B$ & VOA & Dibromochloromethane \\
\hline $8260 B$ & VOA & Dibromochloromethane \\
\hline 8260B & VOA & Dibromochloromethane \\
\hline $8260 B$ & VOA & Dibromochloromethane \\
\hline $8260 B$ & VOA & Dimethylbenzene, Total \\
\hline $8260 B$ & VOA & Dimethylbenzene, Total \\
\hline $8260 B$ & VOA & Dimethylbenzene, Total \\
\hline $8260 B$ & VOA & Dimethylbenzene, Total \\
\hline $8260 B$ & VOA & Dimethylbenzene, Total \\
\hline $8260 B$ & VOA & Dimethylbenzene, Total \\
\hline 8260B & VOA & Dimethylbenzene, Total \\
\hline $8260 B$ & VOA & Dimethylbenzene, Total \\
\hline $8260 B$ & VOA & Dimethylbenzene, Total \\
\hline $8260 B$ & VOA & Dimethylbenzene, Total \\
\hline $8260 B$ & VOA & Dimethylbenzene, Total \\
\hline $8260 B$ & VOA & Dimethylbenzene, Total \\
\hline $8260 B$ & VOA & Dimethylbenzene, Total \\
\hline $8260 B$ & VOA & Dimethylbenzene, Total \\
\hline $8260 B$ & VOA & Ethylbenzene \\
\hline $8260 B$ & VOA & Ethylbenzene \\
\hline $8260 B$ & VOA & Ethylbenzene \\
\hline $8260 B$ & VOA & Ethylbenzene \\
\hline $8260 B$ & VOA & Ethylbenzene \\
\hline $8260 B$ & VOA & Ethylbenzene \\
\hline $8260 B$ & VOA & Ethylbenzene \\
\hline 8260B & VOA & Ethylbenzene \\
\hline $8260 B$ & VOA & Ethylbenzene \\
\hline $8260 B$ & VOA & Ethylbenzene \\
\hline $8260 B$ & VOA & Ethylbenzene \\
\hline 8260B & VOA & Ethylbenzene \\
\hline $8260 B$ & VOA & Ethylbenzene \\
\hline $8260 \mathrm{~B}$ & VOA & Ethylbenzene \\
\hline $8260 B$ & VOA & meta/para Xylene \\
\hline $8260 B$ & VOA & meta/para Xylene \\
\hline $8260 B$ & VOA & meta/para Xylene \\
\hline $8260 B$ & VOA & meta/para Xylene \\
\hline $8260 B$ & VOA & meta/para Xylene \\
\hline $8260 B$ & VOA & meta/para Xylene \\
\hline $8260 B$ & VOA & meta/para Xylene \\
\hline $8260 B$ & VOA & meta/para Xylene \\
\hline $8260 B$ & VOA & meta/para Xylene \\
\hline $8260 B$ & VOA & meta/para Xylene \\
\hline $8260 B$ & VOA & meta/para Xylene \\
\hline $8260 B$ & VOA & meta/para Xylene \\
\hline 8260B & VOA & meta/para Xylene \\
\hline $8260 B$ & VOA & meta/para Xylene \\
\hline $8260 \mathrm{~B}$ & VOA & Methylene chloride \\
\hline $8260 B$ & VOA & Methylene chloride \\
\hline $8260 B$ & VOA & Methylene chloride \\
\hline $8260 \mathrm{~B}$ & VOA & Methylene chloride \\
\hline $8260 B$ & VOA & Methylene chloride \\
\hline $8260 B$ & VOA & Methylene chloride \\
\hline $8260 B$ & VOA & Methylene chloride \\
\hline $8260 B$ & VOA & Methylene chloride \\
\hline $8260 B$ & VOA & Methylene chloride \\
\hline $8260 B$ & VOA & Methylene chloride \\
\hline $8260 B$ & VOA & Methylene chloride \\
\hline $8260 B$ & VOA & Methylene chloride \\
\hline $8260 B$ & VOA & Methylene chloride \\
\hline $8260 B$ & VOA & Methylene chloride \\
\hline $8260 B$ & VOA & Styrene \\
\hline $8260 B$ & VOA & Styrene \\
\hline $8260 B$ & VOA & Styrene \\
\hline $8260 B$ & VOA & Styrene \\
\hline 8260B & VOA & Styrene \\
\hline $8260 \mathrm{~B}$ & VOA & Styrene \\
\hline $8260 \mathrm{~B}$ & VOA & Styrene \\
\hline
\end{tabular}

\begin{tabular}{|c|c|c|}
\hline Station & Result & Error \\
\hline MW242 & 5 & \\
\hline MW243 & 25 & \\
\hline MW262 & 50 & \\
\hline MW340 & 400 & \\
\hline MW381 & 5 & \\
\hline MW66 & 25 & \\
\hline QC & 5 & \\
\hline $\mathrm{QC}$ & 5 & \\
\hline MW125 & 75 & \\
\hline MW168 & 19 & \\
\hline MW185 & 380 & \\
\hline MW194 & 15 & \\
\hline MW197 & 15 & \\
\hline MW236 & 15 & \\
\hline MW242 & 15 & \\
\hline MW243 & 75 & \\
\hline MW262 & 150 & \\
\hline MW340 & 1200 & \\
\hline MW381 & 15 & \\
\hline MW66 & 75 & \\
\hline QC & 15 & \\
\hline $\mathrm{QC}$ & 15 & \\
\hline MW125 & 25 & \\
\hline MW168 & 6.2 & \\
\hline MW185 & 120 & \\
\hline MW194 & 5 & \\
\hline MW197 & 5 & \\
\hline MW236 & 5 & \\
\hline MW242 & 5 & \\
\hline MW243 & 25 & \\
\hline MW262 & 50 & \\
\hline MW340 & 400 & \\
\hline MW381 & 5 & \\
\hline MW66 & 25 & \\
\hline $\mathrm{QC}$ & 5 & \\
\hline QC & 5 & \\
\hline MW125 & 50 & \\
\hline MW168 & 12 & \\
\hline MW185 & 250 & \\
\hline MW194 & 10 & \\
\hline MW197 & 10 & \\
\hline MW236 & 10 & \\
\hline MW242 & 10 & \\
\hline MW243 & 50 & \\
\hline MW262 & 100 & \\
\hline MW340 & 800 & \\
\hline MW381 & 10 & \\
\hline MW66 & 50 & \\
\hline QC & 10 & \\
\hline $\mathrm{QC}$ & 10 & \\
\hline MW125 & 25 & \\
\hline MW168 & 6.2 & \\
\hline MW185 & 120 & \\
\hline MW194 & 5 & \\
\hline MW197 & 5 & \\
\hline MW236 & 5 & \\
\hline MW242 & 5 & \\
\hline MW243 & 25 & \\
\hline MW262 & 50 & \\
\hline MW340 & 400 & \\
\hline MW381 & 5 & \\
\hline MW66 & 25 & \\
\hline QC & 5 & \\
\hline QC & 5 & \\
\hline MW125 & 25 & \\
\hline MW168 & 6.2 & \\
\hline MW185 & 120 & \\
\hline MW194 & 5 & \\
\hline MW197 & 5 & \\
\hline MW236 & 5 & \\
\hline MW242 & 5 & \\
\hline
\end{tabular}

\begin{tabular}{|c|c|c|c|}
\hline Qualifier & $\begin{array}{c}\text { Date } \\
\text { Collected }\end{array}$ & $\begin{array}{c}\text { Date } \\
\text { Analyzed }\end{array}$ & $\begin{array}{l}\text { Detection } \\
\text { Limit }\end{array}$ \\
\hline $\mathrm{U}$ & $12 / 19 / 2007$ & $12 / 27 / 2007$ & 5 \\
\hline$U$ & $12 / 19 / 2007$ & $12 / 27 / 2007$ & 25 \\
\hline$U$ & $12 / 19 / 2007$ & $12 / 27 / 2007$ & 50 \\
\hline U & $12 / 19 / 2007$ & $12 / 27 / 2007$ & 400 \\
\hline $\mathrm{U}$ & $12 / 19 / 2007$ & $12 / 27 / 2007$ & 5 \\
\hline$U$ & $12 / 19 / 2007$ & $12 / 27 / 2007$ & 25 \\
\hline U & $12 / 19 / 2007$ & $12 / 27 / 2007$ & 5 \\
\hline $\mathrm{U}$ & $12 / 19 / 2007$ & $12 / 27 / 2007$ & 5 \\
\hline$U$ & $12 / 19 / 2007$ & $12 / 27 / 2007$ & 75 \\
\hline$U$ & $12 / 19 / 2007$ & $12 / 27 / 2007$ & 19 \\
\hline U & $12 / 19 / 2007$ & $12 / 27 / 2007$ & 380 \\
\hline $\mathrm{U}$ & $12 / 19 / 2007$ & $12 / 27 / 2007$ & 15 \\
\hline$U$ & $12 / 19 / 2007$ & $12 / 27 / 2007$ & 15 \\
\hline$U$ & $12 / 19 / 2007$ & $12 / 27 / 2007$ & 15 \\
\hline $\mathrm{U}$ & $12 / 19 / 2007$ & $12 / 27 / 2007$ & 15 \\
\hline$U$ & $12 / 19 / 2007$ & $12 / 27 / 2007$ & 75 \\
\hline$U$ & $12 / 19 / 2007$ & $12 / 27 / 2007$ & 150 \\
\hline$U$ & $12 / 19 / 2007$ & $12 / 27 / 2007$ & 1200 \\
\hline$U$ & $12 / 19 / 2007$ & $12 / 27 / 2007$ & 15 \\
\hline$U$ & $12 / 19 / 2007$ & $12 / 27 / 2007$ & 75 \\
\hline$U$ & $12 / 19 / 2007$ & $12 / 27 / 2007$ & 15 \\
\hline$U$ & $12 / 19 / 2007$ & $12 / 27 / 2007$ & 15 \\
\hline$U$ & $12 / 19 / 2007$ & $12 / 27 / 2007$ & 25 \\
\hline$U$ & $12 / 19 / 2007$ & $12 / 27 / 2007$ & 6.2 \\
\hline$U$ & $12 / 19 / 2007$ & $12 / 27 / 2007$ & 120 \\
\hline $\mathrm{U}$ & $12 / 19 / 2007$ & $12 / 27 / 2007$ & 5 \\
\hline U & $12 / 19 / 2007$ & $12 / 27 / 2007$ & 5 \\
\hline$U$ & $12 / 19 / 2007$ & $12 / 27 / 2007$ & 5 \\
\hline$U$ & $12 / 19 / 2007$ & $12 / 27 / 2007$ & 5 \\
\hline$U$ & $12 / 19 / 2007$ & $12 / 27 / 2007$ & 25 \\
\hline$U$ & $12 / 19 / 2007$ & $12 / 27 / 2007$ & 50 \\
\hline$U$ & $12 / 19 / 2007$ & $12 / 27 / 2007$ & 400 \\
\hline$U$ & $12 / 19 / 2007$ & $12 / 27 / 2007$ & 5 \\
\hline$U$ & $12 / 19 / 2007$ & $12 / 27 / 2007$ & 25 \\
\hline$U$ & $12 / 19 / 2007$ & $12 / 27 / 2007$ & 5 \\
\hline$U$ & $12 / 19 / 2007$ & $12 / 27 / 2007$ & 5 \\
\hline$U$ & $12 / 19 / 2007$ & $12 / 27 / 2007$ & 50 \\
\hline$U$ & $12 / 19 / 2007$ & $12 / 27 / 2007$ & 12 \\
\hline$U$ & $12 / 19 / 2007$ & $12 / 27 / 2007$ & 250 \\
\hline$U$ & $12 / 19 / 2007$ & $12 / 27 / 2007$ & 10 \\
\hline$U$ & $12 / 19 / 2007$ & $12 / 27 / 2007$ & 10 \\
\hline$U$ & $12 / 19 / 2007$ & $12 / 27 / 2007$ & 10 \\
\hline$U$ & $12 / 19 / 2007$ & $12 / 27 / 2007$ & 10 \\
\hline$U$ & $12 / 19 / 2007$ & $12 / 27 / 2007$ & 50 \\
\hline$U$ & $12 / 19 / 2007$ & $12 / 27 / 2007$ & 100 \\
\hline$U$ & $12 / 19 / 2007$ & $12 / 27 / 2007$ & 800 \\
\hline$U$ & $12 / 19 / 2007$ & $12 / 27 / 2007$ & 10 \\
\hline$U$ & $12 / 19 / 2007$ & $12 / 27 / 2007$ & 50 \\
\hline$U$ & $12 / 19 / 2007$ & $12 / 27 / 2007$ & 10 \\
\hline$U$ & $12 / 19 / 2007$ & $12 / 27 / 2007$ & 10 \\
\hline$U$ & $12 / 19 / 2007$ & $12 / 27 / 2007$ & 25 \\
\hline$U$ & $12 / 19 / 2007$ & $12 / 27 / 2007$ & 6.2 \\
\hline$U$ & $12 / 19 / 2007$ & $12 / 27 / 2007$ & 120 \\
\hline$U$ & $12 / 19 / 2007$ & $12 / 27 / 2007$ & 5 \\
\hline$U$ & $12 / 19 / 2007$ & $12 / 27 / 2007$ & 5 \\
\hline$U$ & $12 / 19 / 2007$ & $12 / 27 / 2007$ & 5 \\
\hline$U$ & $12 / 19 / 2007$ & $12 / 27 / 2007$ & 5 \\
\hline$U$ & $12 / 19 / 2007$ & $12 / 27 / 2007$ & 25 \\
\hline$U$ & $12 / 19 / 2007$ & $12 / 27 / 2007$ & 50 \\
\hline$U$ & $12 / 19 / 2007$ & $12 / 27 / 2007$ & 400 \\
\hline$U$ & $12 / 19 / 2007$ & $12 / 27 / 2007$ & 5 \\
\hline$U$ & $12 / 19 / 2007$ & $12 / 27 / 2007$ & 25 \\
\hline$U$ & $12 / 19 / 2007$ & $12 / 27 / 2007$ & 5 \\
\hline$U$ & $12 / 19 / 2007$ & $12 / 27 / 2007$ & 5 \\
\hline$U$ & $12 / 19 / 2007$ & $12 / 27 / 2007$ & 25 \\
\hline$U$ & $12 / 19 / 2007$ & $12 / 27 / 2007$ & 6.2 \\
\hline$U$ & $12 / 19 / 2007$ & $12 / 27 / 2007$ & 120 \\
\hline$U$ & $12 / 19 / 2007$ & $12 / 27 / 2007$ & 5 \\
\hline$U$ & $12 / 19 / 2007$ & $12 / 27 / 2007$ & 5 \\
\hline$U$ & $12 / 19 / 2007$ & $12 / 27 / 2007$ & 5 \\
\hline $\mathrm{U}$ & $12 / 19 / 2007$ & $12 / 27 / 2007$ & 5 \\
\hline
\end{tabular}




\begin{tabular}{|c|c|c|c|c|c|c|c|c|c|c|}
\hline Method & AnaType & Chemical Name & Station & Result & Error & Units & Qualifier & $\begin{array}{c}\text { Date } \\
\text { Collected }\end{array}$ & $\begin{array}{c}\text { Date } \\
\text { Analyzed }\end{array}$ & $\begin{array}{l}\text { Detection } \\
\text { Limit }\end{array}$ \\
\hline $8260 B$ & VOA & Styrene & MW243 & 25 & & ug/L & $U$ & $12 / 19 / 2007$ & $12 / 27 / 2007$ & 25 \\
\hline $8260 B$ & VOA & Styrene & MW262 & 50 & & ug/L & $\mathrm{U}$ & $12 / 19 / 2007$ & $12 / 27 / 2007$ & 50 \\
\hline $8260 B$ & VOA & Styrene & MW340 & 400 & & $\mathrm{ug} / \mathrm{L}$ & $U$ & $12 / 19 / 2007$ & $12 / 27 / 2007$ & 400 \\
\hline $8260 \mathrm{~B}$ & VOA & Styrene & MW381 & 5 & & $\mathrm{ug} / \mathrm{L}$ & $U$ & $12 / 19 / 2007$ & $12 / 27 / 2007$ & 5 \\
\hline $8260 B$ & VOA & Styrene & MW66 & 25 & & $\mathrm{ug} / \mathrm{L}$ & $U$ & $12 / 19 / 2007$ & $12 / 27 / 2007$ & 25 \\
\hline $8260 B$ & VOA & Styrene & $\mathrm{QC}$ & 5 & & $\mathrm{ug} / \mathrm{L}$ & $\mathrm{U}$ & $12 / 19 / 2007$ & $12 / 27 / 2007$ & 5 \\
\hline $8260 B$ & VOA & Styrene & $\mathrm{QC}$ & 5 & & $\mathrm{ug} / \mathrm{L}$ & $\mathrm{U}$ & $12 / 19 / 2007$ & $12 / 27 / 2007$ & 5 \\
\hline $8260 \mathrm{~B}$ & VOA & Tetrachloroethene & MW125 & 25 & & $\mathrm{ug} / \mathrm{L}$ & $\mathrm{U}$ & $12 / 19 / 2007$ & $12 / 27 / 2007$ & 25 \\
\hline $8260 B$ & VOA & Tetrachloroethene & MW168 & 6.2 & & $\mathrm{ug} / \mathrm{L}$ & $U$ & $12 / 19 / 2007$ & $12 / 27 / 2007$ & 6.2 \\
\hline $8260 B$ & VOA & Tetrachloroethene & MW185 & 120 & & $\mathrm{ug} / \mathrm{L}$ & $U$ & $12 / 19 / 2007$ & $12 / 27 / 2007$ & 120 \\
\hline $8260 B$ & VOA & Tetrachloroethene & MW194 & 5 & & $\mathrm{ug} / \mathrm{L}$ & $\mathrm{U}$ & $12 / 19 / 2007$ & $12 / 27 / 2007$ & 5 \\
\hline $8260 \mathrm{~B}$ & VOA & Tetrachloroethene & MW197 & 5 & & $\mathrm{ug} / \mathrm{L}$ & $\mathrm{U}$ & $12 / 19 / 2007$ & $12 / 27 / 2007$ & 5 \\
\hline $8260 B$ & VOA & Tetrachloroethene & MW236 & 5 & & $\mathrm{ug} / \mathrm{L}$ & $\mathrm{U}$ & $12 / 19 / 2007$ & $12 / 27 / 2007$ & 5 \\
\hline $8260 B$ & VOA & Tetrachloroethene & MW242 & 5 & & $\mathrm{ug} / \mathrm{L}$ & $U$ & $12 / 19 / 2007$ & $12 / 27 / 2007$ & 5 \\
\hline $8260 B$ & VOA & Tetrachloroethene & MW243 & 25 & & $\mathrm{ug} / \mathrm{L}$ & $U$ & $12 / 19 / 2007$ & $12 / 27 / 2007$ & 25 \\
\hline $8260 B$ & VOA & Tetrachloroethene & MW262 & 50 & & $\mathrm{ug} / \mathrm{L}$ & $U$ & $12 / 19 / 2007$ & $12 / 27 / 2007$ & 50 \\
\hline $8260 B$ & VOA & Tetrachloroethene & MW340 & 400 & & $\mathrm{ug} / \mathrm{L}$ & $U$ & $12 / 19 / 2007$ & $12 / 27 / 2007$ & 400 \\
\hline $8260 B$ & VOA & Tetrachloroethene & MW381 & 5 & & $\mathrm{ug} / \mathrm{L}$ & $U$ & $12 / 19 / 2007$ & $12 / 27 / 2007$ & 5 \\
\hline $8260 B$ & VOA & Tetrachloroethene & MW66 & 25 & & ug/L & $U$ & $12 / 19 / 2007$ & $12 / 27 / 2007$ & 25 \\
\hline $8260 B$ & VOA & Tetrachloroethene & QC & 5 & & $\mathrm{ug} / \mathrm{L}$ & $U$ & $12 / 19 / 2007$ & $12 / 27 / 2007$ & 5 \\
\hline $8260 B$ & VOA & Tetrachloroethene & QC & 5 & & $\mathrm{ug} / \mathrm{L}$ & $U$ & $12 / 19 / 2007$ & $12 / 27 / 2007$ & 5 \\
\hline $8260 B$ & VOA & Toluene & MW125 & 25 & & $\mathrm{ug} / \mathrm{L}$ & $U$ & $12 / 19 / 2007$ & $12 / 27 / 2007$ & 25 \\
\hline $8260 B$ & VOA & Toluene & MW168 & 6.2 & & $\mathrm{ug} / \mathrm{L}$ & $U$ & $12 / 19 / 2007$ & $12 / 27 / 2007$ & 6.2 \\
\hline $8260 B$ & VOA & Toluene & MW185 & 120 & & $\mathrm{ug} / \mathrm{L}$ & $U$ & $12 / 19 / 2007$ & $12 / 27 / 2007$ & 120 \\
\hline $8260 B$ & VOA & Toluene & MW194 & 5 & & $\mathrm{ug} / \mathrm{L}$ & $U$ & $12 / 19 / 2007$ & $12 / 27 / 2007$ & 5 \\
\hline $8260 B$ & VOA & Toluene & MW197 & 5 & & $\mathrm{ug} / \mathrm{L}$ & $\mathrm{U}$ & $12 / 19 / 2007$ & $12 / 27 / 2007$ & 5 \\
\hline $8260 B$ & VOA & Toluene & MW236 & 5 & & $\mathrm{ug} / \mathrm{L}$ & $U$ & $12 / 19 / 2007$ & $12 / 27 / 2007$ & 5 \\
\hline $8260 B$ & VOA & Toluene & MW242 & 5 & & $\mathrm{ug} / \mathrm{L}$ & $\mathrm{U}$ & $12 / 19 / 2007$ & $12 / 27 / 2007$ & 5 \\
\hline $8260 B$ & VOA & Toluene & MW243 & 25 & & ug/L & $U$ & $12 / 19 / 2007$ & $12 / 27 / 2007$ & 25 \\
\hline $8260 B$ & VOA & Toluene & MW262 & 50 & & $\mathrm{ug} / \mathrm{L}$ & $\mathrm{U}$ & $12 / 19 / 2007$ & $12 / 27 / 2007$ & 50 \\
\hline $8260 B$ & VOA & Toluene & MW340 & 400 & & $\mathrm{ug} / \mathrm{L}$ & $U$ & $12 / 19 / 2007$ & $12 / 27 / 2007$ & 400 \\
\hline $8260 B$ & VOA & Toluene & MW381 & 5 & & $\mathrm{ug} / \mathrm{L}$ & $\mathrm{U}$ & $12 / 19 / 2007$ & $12 / 27 / 2007$ & 5 \\
\hline $8260 B$ & VOA & Toluene & MW66 & 25 & & $\mathrm{ug} / \mathrm{L}$ & U & $12 / 19 / 2007$ & $12 / 27 / 2007$ & 25 \\
\hline $8260 B$ & VOA & Toluene & QC & 5 & & $\mathrm{ug} / \mathrm{L}$ & $U$ & $12 / 19 / 2007$ & $12 / 27 / 2007$ & 5 \\
\hline $8260 B$ & VOA & Toluene & QC & 5 & & $\mathrm{ug} / \mathrm{L}$ & $U$ & $12 / 19 / 2007$ & $12 / 27 / 2007$ & 5 \\
\hline $8260 B$ & VOA & trans-1,2-Dichloroethene & MW125 & 5 & & $\mathrm{ug} / \mathrm{L}$ & $U$ & $12 / 19 / 2007$ & $12 / 27 / 2007$ & 5 \\
\hline $8260 B$ & VOA & trans-1,2-Dichloroethene & MW168 & 1.2 & & $\mathrm{ug} / \mathrm{L}$ & $U$ & $12 / 19 / 2007$ & $12 / 27 / 2007$ & 1.2 \\
\hline $8260 B$ & VOA & trans-1,2-Dichloroethene & MW185 & 25 & & $\mathrm{ug} / \mathrm{L}$ & $U$ & $12 / 19 / 2007$ & $12 / 27 / 2007$ & 25 \\
\hline $8260 B$ & VOA & trans-1,2-Dichloroethene & MW194 & 1 & & $\mathrm{ug} / \mathrm{L}$ & $U$ & $12 / 19 / 2007$ & $12 / 27 / 2007$ & 1 \\
\hline $8260 B$ & VOA & trans-1,2-Dichloroethene & MW197 & 1 & & $\mathrm{ug} / \mathrm{L}$ & $U$ & $12 / 19 / 2007$ & $12 / 27 / 2007$ & 1 \\
\hline $8260 B$ & VOA & trans-1,2-Dichloroethene & MW236 & 1 & & $\mathrm{ug} / \mathrm{L}$ & $U$ & $12 / 19 / 2007$ & $12 / 27 / 2007$ & 1 \\
\hline $8260 B$ & VOA & trans-1,2-Dichloroethene & MW242 & 1 & & $\mathrm{ug} / \mathrm{L}$ & $U$ & $12 / 19 / 2007$ & $12 / 27 / 2007$ & 1 \\
\hline $8260 B$ & VOA & trans-1,2-Dichloroethene & MW243 & 5 & & $\mathrm{ug} / \mathrm{L}$ & $\mathrm{U}$ & $12 / 19 / 2007$ & $12 / 27 / 2007$ & 5 \\
\hline $8260 B$ & VOA & trans-1,2-Dichloroethene & MW262 & 10 & & $\mathrm{ug} / \mathrm{L}$ & $U$ & $12 / 19 / 2007$ & $12 / 27 / 2007$ & 10 \\
\hline $8260 \mathrm{~B}$ & VOA & trans-1,2-Dichloroethene & MW340 & 80 & & $\mathrm{ug} / \mathrm{L}$ & $\mathrm{U}$ & $12 / 19 / 2007$ & $12 / 27 / 2007$ & 80 \\
\hline $8260 B$ & VOA & trans-1,2-Dichloroethene & MW381 & 1 & & $\mathrm{ug} / \mathrm{L}$ & $U$ & $12 / 19 / 2007$ & $12 / 27 / 2007$ & 1 \\
\hline $8260 B$ & VOA & trans-1,2-Dichloroethene & MW66 & 5 & & $\mathrm{ug} / \mathrm{L}$ & $\mathrm{U}$ & $12 / 19 / 2007$ & $12 / 27 / 2007$ & 5 \\
\hline $8260 B$ & VOA & trans-1,2-Dichloroethene & $\mathrm{QC}$ & 1 & & $\mathrm{ug} / \mathrm{L}$ & $U$ & $12 / 19 / 2007$ & $12 / 27 / 2007$ & 1 \\
\hline $8260 B$ & VOA & trans-1,2-Dichloroethene & $\mathrm{QC}$ & 1 & & $\mathrm{ug} / \mathrm{L}$ & $\mathrm{U}$ & $12 / 19 / 2007$ & $12 / 27 / 2007$ & 1 \\
\hline $8260 B$ & VOA & trans-1,3-Dichloropropene & MW125 & 25 & & $\mathrm{ug} / \mathrm{L}$ & $U$ & $12 / 19 / 2007$ & $12 / 27 / 2007$ & 25 \\
\hline $8260 B$ & VOA & trans-1,3-Dichloropropene & MW168 & 6.2 & & $\mathrm{ug} / \mathrm{L}$ & $U$ & $12 / 19 / 2007$ & $12 / 27 / 2007$ & 6.2 \\
\hline $8260 B$ & VOA & trans-1,3-Dichloropropene & MW185 & 120 & & $\mathrm{ug} / \mathrm{L}$ & $U$ & $12 / 19 / 2007$ & $12 / 27 / 2007$ & 120 \\
\hline $8260 B$ & VOA & trans-1,3-Dichloropropene & MW194 & 5 & & $\mathrm{ug} / \mathrm{L}$ & $U$ & $12 / 19 / 2007$ & $12 / 27 / 2007$ & 5 \\
\hline $8260 B$ & VOA & trans-1,3-Dichloropropene & MW197 & 5 & & $\mathrm{ug} / \mathrm{L}$ & $U$ & $12 / 19 / 2007$ & $12 / 27 / 2007$ & 5 \\
\hline $8260 B$ & VOA & trans-1,3-Dichloropropene & MW236 & 5 & & ug/L & $U$ & $12 / 19 / 2007$ & $12 / 27 / 2007$ & 5 \\
\hline $8260 B$ & VOA & trans-1,3-Dichloropropene & MW242 & 5 & & $\mathrm{ug} / \mathrm{L}$ & $\mathrm{U}$ & $12 / 19 / 2007$ & $12 / 27 / 2007$ & 5 \\
\hline $8260 B$ & VOA & trans-1,3-Dichloropropene & MW243 & 25 & & $\mathrm{ug} / \mathrm{L}$ & $U$ & $12 / 19 / 2007$ & $12 / 27 / 2007$ & 25 \\
\hline $8260 B$ & VOA & trans-1,3-Dichloropropene & MW262 & 50 & & $\mathrm{ug} / \mathrm{L}$ & $U$ & $12 / 19 / 2007$ & $12 / 27 / 2007$ & 50 \\
\hline $8260 B$ & VOA & trans-1,3-Dichloropropene & MW340 & 400 & & $\mathrm{ug} / \mathrm{L}$ & $\mathrm{U}$ & $12 / 19 / 2007$ & $12 / 27 / 2007$ & 400 \\
\hline $8260 B$ & VOA & trans-1,3-Dichloropropene & MW381 & 5 & & $\mathrm{ug} / \mathrm{L}$ & $U$ & $12 / 19 / 2007$ & $12 / 27 / 2007$ & 5 \\
\hline $8260 B$ & VOA & trans-1,3-Dichloropropene & MW66 & 25 & & $\mathrm{ug} / \mathrm{L}$ & $U$ & $12 / 19 / 2007$ & $12 / 27 / 2007$ & 25 \\
\hline $8260 B$ & VOA & trans-1,3-Dichloropropene & $\mathrm{QC}$ & 5 & & $\mathrm{ug} / \mathrm{L}$ & $\mathrm{U}$ & $12 / 19 / 2007$ & $12 / 27 / 2007$ & 5 \\
\hline $8260 B$ & VOA & trans-1,3-Dichloropropene & QC & 5 & & $\mathrm{ug} / \mathrm{L}$ & $U$ & $12 / 19 / 2007$ & $12 / 27 / 2007$ & 5 \\
\hline $8260 B$ & VOA & Trichloroethene & MW125 & 620 & & $\mathrm{ug} / \mathrm{L}$ & $\mathrm{D}$ & $12 / 19 / 2007$ & $12 / 27 / 2007$ & 5 \\
\hline $8260 B$ & VOA & Trichloroethene & MW168 & 110 & & $\mathrm{ug} / \mathrm{L}$ & $\mathrm{D}$ & $12 / 19 / 2007$ & $12 / 27 / 2007$ & 1.2 \\
\hline $8260 B$ & VOA & Trichloroethene & MW185 & 3600 & & $\mathrm{ug} / \mathrm{L}$ & $\mathrm{D}$ & $12 / 19 / 2007$ & $12 / 27 / 2007$ & 25 \\
\hline $8260 B$ & VOA & Trichloroethene & MW194 & 1 & & $\mathrm{ug} / \mathrm{L}$ & $\mathrm{U}$ & $12 / 19 / 2007$ & $12 / 27 / 2007$ & 1 \\
\hline $8260 B$ & VOA & Trichloroethene & MW197 & 3.5 & & $\mathrm{ug} / \mathrm{L}$ & & $12 / 19 / 2007$ & $12 / 27 / 2007$ & 1 \\
\hline $8260 B$ & VOA & Trichloroethene & MW236 & 72 & & $\mathrm{ug} / \mathrm{L}$ & & $12 / 19 / 2007$ & $12 / 27 / 2007$ & 1 \\
\hline $8260 B$ & VOA & Trichloroethene & MW242 & 150 & & $\mathrm{ug} / \mathrm{L}$ & & $12 / 19 / 2007$ & $12 / 27 / 2007$ & 1 \\
\hline $8260 B$ & VOA & Trichloroethene & MW243 & 590 & & ug/L & $\mathrm{D}$ & $12 / 19 / 2007$ & $12 / 27 / 2007$ & 5 \\
\hline
\end{tabular}




\begin{tabular}{|c|c|c|c|c|c|c|c|c|c|c|}
\hline Method & AnaType & Chemical Name & Station & Result & Error & Units & Qualifier & $\begin{array}{c}\text { Date } \\
\text { Collected }\end{array}$ & $\begin{array}{c}\text { Date } \\
\text { Analyzed }\end{array}$ & $\begin{array}{l}\text { Detection } \\
\text { Limit }\end{array}$ \\
\hline $8260 B$ & VOA & Trichloroethene & MW262 & 1400 & & ug/L & $\mathrm{D}$ & $12 / 19 / 2007$ & $12 / 27 / 2007$ & 10 \\
\hline $8260 B$ & VOA & Trichloroethene & MW340 & 9700 & & ug/L & $\mathrm{D}$ & $12 / 19 / 2007$ & $12 / 27 / 2007$ & 80 \\
\hline $8260 B$ & VOA & Trichloroethene & MW381 & 47 & & $\mathrm{ug} / \mathrm{L}$ & & $12 / 19 / 2007$ & $12 / 27 / 2007$ & 1 \\
\hline $8260 B$ & VOA & Trichloroethene & MW66 & 930 & & ug/L & $\mathrm{D}$ & $12 / 19 / 2007$ & $12 / 27 / 2007$ & 10 \\
\hline $8260 B$ & VOA & Trichloroethene & $\mathrm{QC}$ & 1 & & ug/L & $U$ & $12 / 19 / 2007$ & $12 / 27 / 2007$ & 1 \\
\hline $8260 B$ & VOA & Trichloroethene & QC & 1 & & ug/L & $U$ & $12 / 19 / 2007$ & $12 / 27 / 2007$ & 1 \\
\hline $8260 B$ & VOA & Vinyl acetate & MW125 & 50 & & $\mathrm{ug} / \mathrm{L}$ & $\mathrm{U}$ & $12 / 19 / 2007$ & $12 / 27 / 2007$ & 50 \\
\hline $8260 B$ & VOA & Vinyl acetate & MW168 & 12 & & ug/L & $U$ & $12 / 19 / 2007$ & $12 / 27 / 2007$ & 12 \\
\hline $8260 B$ & VOA & Vinyl acetate & MW185 & 250 & & ug/L & $U$ & $12 / 19 / 2007$ & $12 / 27 / 2007$ & 250 \\
\hline $8260 B$ & VOA & Vinyl acetate & MW194 & 10 & & ug/L & $U$ & $12 / 19 / 2007$ & $12 / 27 / 2007$ & 10 \\
\hline $8260 \mathrm{~B}$ & VOA & Vinyl acetate & MW197 & 10 & & ug/L & $U$ & $12 / 19 / 2007$ & $12 / 27 / 2007$ & 10 \\
\hline $8260 B$ & VOA & Vinyl acetate & MW236 & 10 & & ug/L & $U$ & $12 / 19 / 2007$ & $12 / 27 / 2007$ & 10 \\
\hline $8260 B$ & VOA & Vinyl acetate & MW242 & 10 & & $\mathrm{ug} / \mathrm{L}$ & $\mathrm{U}$ & $12 / 19 / 2007$ & $12 / 27 / 2007$ & 10 \\
\hline $8260 B$ & VOA & Vinyl acetate & MW243 & 50 & & $\mathrm{ug} / \mathrm{L}$ & 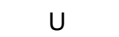 & $12 / 19 / 2007$ & $12 / 27 / 2007$ & 50 \\
\hline $8260 B$ & VOA & Vinyl acetate & MW262 & 100 & & ug/L & $U$ & $12 / 19 / 2007$ & $12 / 27 / 2007$ & 100 \\
\hline $8260 B$ & VOA & Vinyl acetate & MW340 & 800 & & ug/L & $U$ & $12 / 19 / 2007$ & $12 / 27 / 2007$ & 800 \\
\hline $8260 B$ & VOA & Vinyl acetate & MW381 & 10 & & ug/L & $U$ & $12 / 19 / 2007$ & $12 / 27 / 2007$ & 10 \\
\hline $8260 B$ & VOA & Vinyl acetate & MW66 & 50 & & $\mathrm{ug} / \mathrm{L}$ & U & $12 / 19 / 2007$ & $12 / 27 / 2007$ & 50 \\
\hline $8260 B$ & VOA & Vinyl acetate & $\mathrm{QC}$ & 10 & & ug/L & $U$ & $12 / 19 / 2007$ & $12 / 27 / 2007$ & 10 \\
\hline $8260 B$ & VOA & Vinyl acetate & QC & 10 & & ug/L & $U$ & $12 / 19 / 2007$ & $12 / 27 / 2007$ & 10 \\
\hline $8260 B$ & VOA & Vinyl chloride & MW125 & 10 & & ug/L & $U$ & $12 / 19 / 2007$ & $12 / 27 / 2007$ & 10 \\
\hline $8260 B$ & VOA & Vinyl chloride & MW168 & 2.5 & & $\mathrm{ug} / \mathrm{L}$ & U & $12 / 19 / 2007$ & $12 / 27 / 2007$ & 2.5 \\
\hline $8260 B$ & VOA & Vinyl chloride & MW185 & 50 & & ug/L & $U$ & $12 / 19 / 2007$ & $12 / 27 / 2007$ & 50 \\
\hline $8260 B$ & VOA & Vinyl chloride & MW194 & 2 & & ug/L & $U$ & $12 / 19 / 2007$ & $12 / 27 / 2007$ & 2 \\
\hline $8260 B$ & VOA & Vinyl chloride & MW197 & 2 & & ug/L & $U$ & $12 / 19 / 2007$ & $12 / 27 / 2007$ & 2 \\
\hline $8260 \mathrm{~B}$ & VOA & Vinyl chloride & MW236 & 2 & & $\mathrm{ug} / \mathrm{L}$ & $\mathrm{U}$ & $12 / 19 / 2007$ & $12 / 27 / 2007$ & 2 \\
\hline $8260 B$ & VOA & Vinyl chloride & MW242 & 2 & & ug/L & $U$ & $12 / 19 / 2007$ & $12 / 27 / 2007$ & 2 \\
\hline $8260 B$ & VOA & Vinyl chloride & MW243 & 10 & & ug/L & $\mathrm{U}$ & $12 / 19 / 2007$ & $12 / 27 / 2007$ & 10 \\
\hline $8260 B$ & VOA & Vinyl chloride & MW262 & 20 & & ug/L & $U$ & $12 / 19 / 2007$ & $12 / 27 / 2007$ & 20 \\
\hline $8260 \mathrm{~B}$ & VOA & Vinyl chloride & MW340 & 160 & & $\mathrm{ug} / \mathrm{L}$ & $\mathrm{U}$ & $12 / 19 / 2007$ & $12 / 27 / 2007$ & 160 \\
\hline $8260 B$ & VOA & Vinyl chloride & MW381 & 2 & & $\mathrm{ug} / \mathrm{L}$ & $U$ & $12 / 19 / 2007$ & $12 / 27 / 2007$ & 2 \\
\hline $8260 B$ & VOA & Vinyl chloride & MW66 & 10 & & ug/L & $\mathrm{U}$ & $12 / 19 / 2007$ & $12 / 27 / 2007$ & 10 \\
\hline $8260 B$ & VOA & Vinyl chloride & QC & 2 & & $\mathrm{ug} / \mathrm{L}$ & $\mathrm{U}$ & $12 / 19 / 2007$ & $12 / 27 / 2007$ & 2 \\
\hline $8260 B$ & VOA & Vinyl chloride & QC & 2 & & ug/L & $\mathrm{U}$ & $12 / 19 / 2007$ & $12 / 27 / 2007$ & 2 \\
\hline FS & WETCHEM & Conductivity & MW125 & 310 & & umho/cm & & $12 / 19 / 2007$ & & \\
\hline FS & WETCHEM & Conductivity & MW168 & 492 & & umho/cm & & $12 / 19 / 2007$ & & \\
\hline FS & WETCHEM & Conductivity & MW185 & 382 & & umho/cm & & $12 / 19 / 2007$ & & \\
\hline FS & WETCHEM & Conductivity & MW194 & 251 & & umho/cm & & $12 / 19 / 2007$ & & \\
\hline FS & WETCHEM & Conductivity & MW197 & 424 & & umho/cm & & $12 / 19 / 2007$ & & \\
\hline FS & WETCHEM & Conductivity & MW236 & 502 & & umho/cm & & $12 / 19 / 2007$ & & \\
\hline FS & WETCHEM & Conductivity & MW242 & 395 & & umho/cm & & $12 / 19 / 2007$ & & \\
\hline FS & WETCHEM & Conductivity & MW243 & 378 & & umho/cm & & $12 / 19 / 2007$ & & \\
\hline FS & WETCHEM & Conductivity & MW262 & 601 & & umho/cm & & $12 / 19 / 2007$ & & \\
\hline FS & WETCHEM & Conductivity & MW340 & 453 & & umho/cm & & $12 / 19 / 2007$ & & \\
\hline FS & WETCHEM & Conductivity & MW381 & 502 & & umho/cm & & $12 / 19 / 2007$ & & \\
\hline FS & WETCHEM & Conductivity & MW66 & 190 & & umho/cm & & $12 / 19 / 2007$ & & \\
\hline FS & WETCHEM & Turbidity & MW125 & 20.2 & & NTU & & $12 / 19 / 2007$ & & \\
\hline FS & WETCHEM & Turbidity & MW168 & 65.1 & & NTU & & $12 / 19 / 2007$ & & \\
\hline FS & WETCHEM & Turbidity & MW185 & 7.2 & & NTU & & $12 / 19 / 2007$ & & \\
\hline FS & WETCHEM & Turbidity & MW194 & 5.9 & & NTU & & $12 / 19 / 2007$ & & \\
\hline FS & WETCHEM & Turbidity & MW197 & 43.5 & & $\mathrm{mV}$ & & $12 / 19 / 2007$ & & \\
\hline $\mathrm{FS}$ & WETCHEM & Turbidity & MW236 & 4.3 & & NTU & & $12 / 19 / 2007$ & & \\
\hline FS & WETCHEM & Turbidity & MW242 & 63.3 & & NTU & & $12 / 19 / 2007$ & & \\
\hline $\mathrm{FS}$ & WETCHEM & Turbidity & MW243 & 2.3 & & NTU & & $12 / 19 / 2007$ & & \\
\hline FS & WETCHEM & Turbidity & MW262 & 20.7 & & NTU & & $12 / 19 / 2007$ & & \\
\hline FS & WETCHEM & Turbidity & MW340 & 6.5 & & NTU & & $12 / 19 / 2007$ & & \\
\hline FS & WETCHEM & Turbidity & MW381 & 4.3 & & NTU & & $12 / 19 / 2007$ & & \\
\hline FS & WETCHEM & Turbidity & MW66 & 7.1 & & NTU & & $12 / 19 / 2007$ & & \\
\hline
\end{tabular}


Appendix B

TRFLP Report 


\section{Paducah Groundwater Microbial Diversity Summary}

April 2008

\section{Overview:}

The objective of this project was to evaluate microbial biomass and diversity targeting the $16 \mathrm{~S}$ rRNA gene of Bacteria in groundwater collected from the Paducah Gaseous Diffusion Plant (PGDP), North West plume, Kentucky using DNA extraction and Terminal Restriction Fragment Length Polymorphism (T-RFLP). Table 1 describes the sample matrix and the condition of the samples upon arrival to the analytical laboratory.

Table 1. Description of Paducah Site samples and volume filtered for DNA extraction.

\begin{tabular}{|c|c|c|c|}
\hline Well Location & Matrix & Condition Received & Volume Filtered \\
\hline 1. MW 381 & Groundwater & $4^{\circ} \mathrm{C} /$ bottles intact & $250 \mathrm{~mL}$ \\
\hline 2. MW 185 & Groundwater & $4^{\circ} \mathrm{C} /$ bottles intact & $250 \mathrm{~mL}$ \\
\hline 3. MW 243 & Groundwater & $4^{\circ} \mathrm{C} /$ bottles intact & $250 \mathrm{~mL}$ \\
\hline 4. MW 236 & Groundwater & $4^{\circ} \mathrm{C} /$ bottles intact & $250 \mathrm{~mL}$ \\
\hline 5. MW 262 & Groundwater & $4^{\circ} \mathrm{C} /$ bottles intact & $250 \mathrm{~mL}$ \\
\hline 6. MW 340 & Groundwater & $4^{\circ} \mathrm{C} /$ bottles intact & $250 \mathrm{~mL}$ \\
\hline 7. MW 194 & Groundwater & $4^{\circ} \mathrm{C} /$ bottles intact & $250 \mathrm{~mL}$ \\
\hline 8. MW 197 & Groundwater & $4^{\circ} \mathrm{C} /$ bottles intact & $250 \mathrm{~mL}$ \\
\hline 9. MW 66 & Groundwater & $4^{\circ} \mathrm{C} /$ bottles intact & $250 \mathrm{~mL}$ \\
\hline 10. MW 242 & Groundwater & $4^{\circ} \mathrm{C} /$ bottles intact & $250 \mathrm{~mL}$ \\
\hline 11. MW 168 & Groundwater & $4^{\circ} \mathrm{C} /$ bottles intact & $250 \mathrm{~mL}$ \\
\hline 12. MW 125 & Groundwater & $4^{\circ} \mathrm{C} /$ bottles intact & $250 \mathrm{~mL}$ \\
\hline 13. MW 197* & Groundwater & $4^{\circ} \mathrm{C} /$ bottles intact & $250 \mathrm{~mL}$ \\
\hline 14. MW 262* & Groundwater & $4^{\circ} \mathrm{C} /$ bottles intact & $250 \mathrm{~mL}$ \\
\hline
\end{tabular}

* Samples represent the “re-sample” in January 2008. 


\section{North Wind}

\section{Methods:}

DNA Extraction: $200 \mathrm{~mL}$ of groundwater was filtered using sterile $0.2-\mu \mathrm{m}$ Supor filters and filter apparatus. The filters were frozen at $-80^{\circ} \mathrm{C}$, shattered and then divided between two extraction kits: Bio 101 and MoBio. Both kits were used for DNA extraction according to the manufacturer's instructions. Community DNA was eluted in $100 \mu \mathrm{L}$ of $0.1 \mathrm{x}$ Tris HCL and stored at $-20^{\circ} \mathrm{C}$.

Amplification of Bacteria: Following DNA extraction, the samples were first subjected to polymerase chain reaction (PCR) using universal bacterial probes in order to verify that amplifiable DNA was present in the samples. The PCR was used to amplify nearly full-length $16 \mathrm{~S}$ rRNA genes from Bacteria. Each 25- $\mu \mathrm{L}$ PCR reaction included $0.4 \mathrm{mg}$ mL-1 molecular-grade BSA (Sigma Chemicals), $1 \mathrm{X}$ PCR buffer (Promega), $1.5 \mathrm{mM} \mathrm{MgCl}_{2}, 0.5 \mu \mathrm{M}$ each forward and reverse primer (Invitrogen), $1 \mathrm{U}$ Taq DNA polymerase (Promega), $0.2 \mathrm{mM}$ each dNTP (Invitrogen), $1 \mu \mathrm{L}$ template DNA, and molecular-grade water (Promega). Amplification was performed on a PerkinElmer Model 9600 thermocycler using the following regime: $94^{\circ} \mathrm{C}(5 \mathrm{~min})$ followed by 25 cycles of $94^{\circ} \mathrm{C}(1 \mathrm{~min}), 53.5^{\circ} \mathrm{C}(1 \mathrm{~min})$, and $72^{\circ} \mathrm{C}(1$ $\min )$. The reaction was finished with an additional 7 minutes at $72^{\circ} \mathrm{C}$. PCR products were examined in a $1.2 \%$ agarose gel stained with ethidium bromide to confirm specificity of the amplification reactions.

T-RFLP PCR: The polymerase chain reaction (PCR) was used to amplify the 16S rRNA genes from Bacteria 16S rRNA gene. Each 50- $\mu \mathrm{L}$ PCR reaction included $0.4 \mathrm{mg} \mathrm{mL}^{-1}$ molecular-grade BSA (Sigma Chemicals), 1X PCR buffer (Promega), $1.5 \mathrm{mM} \mathrm{MgCl}_{2}, 0.5 \mu \mathrm{M}$ each forward and reverse primer (Invitrogen), $1 \mathrm{U}$ Taq DNA polymerase (Promega), $0.2 \mathrm{mM}$ each dNTP (Invitrogen), $1 \mu \mathrm{L}$ template DNA, and molecular-grade water (Promega). Universal eubacterial primer 8F (5'-AGA GTT TGA TCC TGG CTC AG-3') modified with phosphoramidite fluorochrome 5-carboxyfluorescein (Invitrogen) and 907R (5’-GGT TAC CTT GTT ACG ACT T-3') was used. The thermocycler conditions and agarose gel imaging were performed as described above.

T-RFLP Digestion/Analysis. Triplicate PCR products were generated from each DNA extraction andcombined and purified using the QIAquick PCR Purification Kits (Qiagen). PCR product concentration was estimated by measurement of absorbed UV light at $\lambda=260 \mathrm{~nm}$. Approximately 200 ng of PCR product was digested with MspI ( $1 \mathrm{U}$ ) (New England BioLabs) at $37^{\circ} \mathrm{C}$ for $3 \mathrm{~h}$. The digested fragments were purified using ethanol precipitation as described elsewhere, and the DNA pellet was resuspended in $10 \mu \mathrm{L}$ DNAse-free water. Samples were denatured by heating to $95^{\circ} \mathrm{C}$ for 3 min followed by submersion in an ice bath. The denatured DNA $(2 \mu \mathrm{L})$, along with the internal standard Rox 1000 (Applied Biosystems), was loaded onto a model 3100 DNA sequencer (Applied Biosystems). The resulting data were analyzed using Genescan v 3.1 (Applied Biosystems).

Each PCR preparation was run in triplicate on the DNA sequencer to generate replicate T-RFLP profiles of each sample. These replicates were aligned manually and composite profiles were generated of reproducible T-RFs. T-RFs that differed by less than $0.5 \mathrm{bp}$ were considered identical and assigned the average size and peak heights of the fragments making up the composite T-RF. Any T-RF averaging < 70 bp or not occurring in all of the replicate profiles was discarded. Likewise, any T-RF within a composite profile with peak height averaging $<100$ fluorescence units was also discarded. The sum of all T-RF peak heights $>100$ florescence units was used as an indicator of the total DNA quantity represented, and peak heights were normalized to the replicate with the lowest total fluorescence. 


\section{North Wind}

\section{Results:}

Table 2 summarizes the results of the PGDP project samples. The DNA extraction negative control and all PCR negative controls did not amplify any product. In addition, all calibration control checks were within acceptable values.

Table 2. Results of molecular analyses for the PGDP North West plume samples.

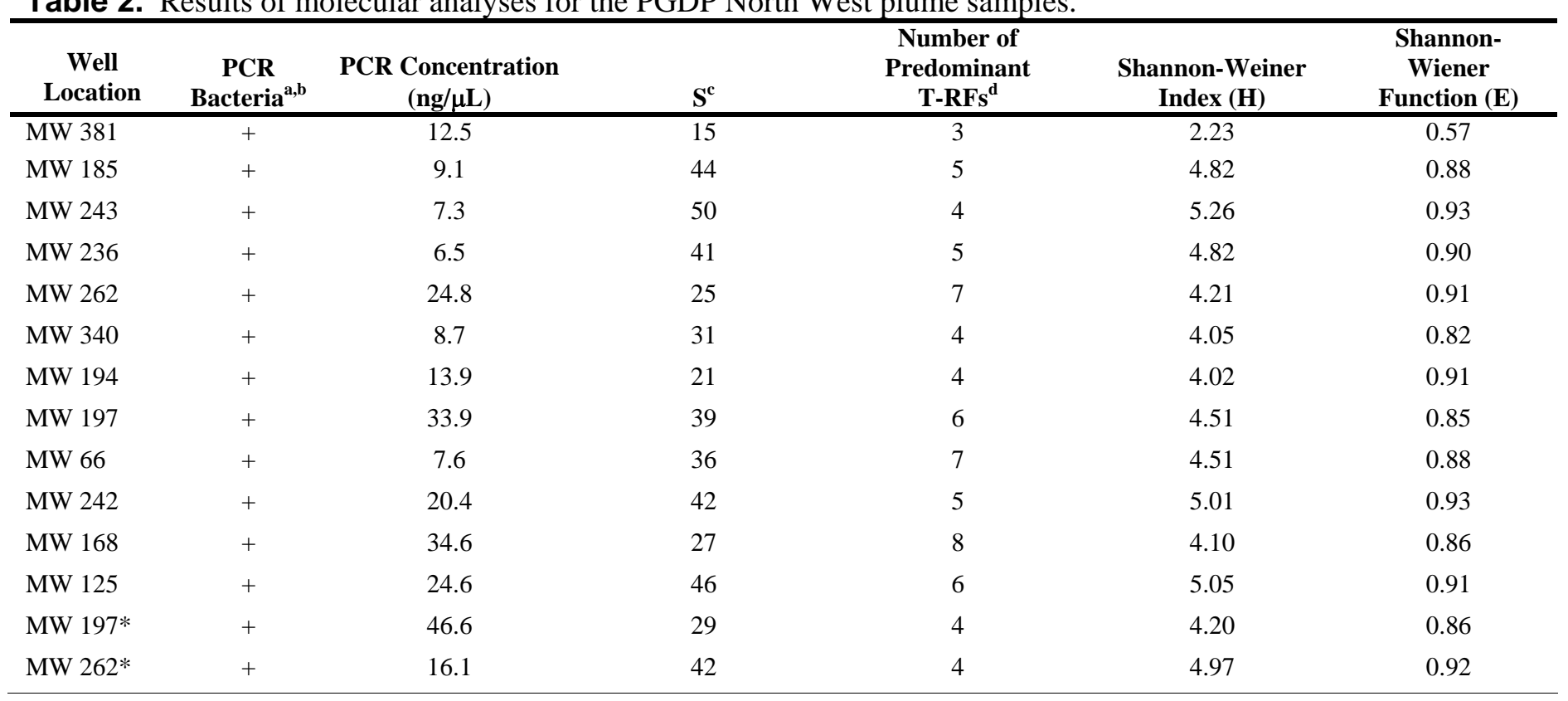




\section{North Wind}

\section{Summary:}

The total cell counts, DAPI can be used as an indicator of relative biomass levels for the samples in order to make relative comparisons. All DAPI counts were similar for the groundwater samples evaluated (previous report). The DNA amplified from these samples can also be used as a relative indicator of biomass. DNA extractions yielded sufficient DNA to amplify Bacteria in a universal PCR reaction. These products were visualized by gel electrophoresis, confirming that amplifiable DNA was obtained from each sample. Overall, however, the DNA yield was relatively low indicating low-levels of biomass present within the samples, based on readily amplifiable DNA and consequently cells.

The number of predominant terminal restriction fragments (T-RFs) generated in each T-RFLP community profile was used as an indicator of the number of microbial bacterial populations present, or the species richness (S), and the relative fluorescence percentage (see T-RFLP profiles below) was used as an indicator of the relative abundance of a species within the microbial community (Table 2). These assumptions allow the calculation of similarity and diversity indices between the different T-RFLP profiles. The ShannonWeiner diversity index $(\mathrm{H})$ (also referred to as the Shannon-Weaver index) was used to estimate the diversity (i.e., richness and evenness) of T-RFs within the T-RFLP profiles. The Shannon-Weiner index evaluates the diversity while accounting for species richness and proportion, or evenness, of the community with higher $\mathrm{H}$ values indicate greater diversity in the microbial community. However, communities that have a higher number of T-RFs, but have a T-RF that is very abundant, will have a lower Shannon-Weiner index than a community with a lower number of fragments where the fragments are all similar in proportion. The Shannon-Weiner Function (E) is an indicator for evenness, or similarity between relative proportions, of T-RFs within the community profiles. T-RFLP profiles with similar, or equal, proportions of all T-RFs have an E value of one, but when the abundance is very dissimilar or one species dominates then the value decreases.

Of the Paducah samples, MW 194 and MW 381 had the lowest biomass, based on the evaluation of DNA concentration. However, all of the samples successfully amplified Bacteria, and T-RFLP profiles generated. In general T-RFLP indicates that all of the samples were relatively diverse, with the exception of MW 381, which was substantially less diverse than the other samples as indicated by a lower, number of observed T-RFs, the prevalence of 3 dominant T-RFs that comprised $>77 \%$ of the total T-RFLP community, resulting in significantly lower Shannon-Weiner index and function.

In looking at similarity between the profiles, the majority of the profiles were statistically, significantly different (see T-RFLP profiles below). Of the predominant T-RFs evaluated, only T-RF 134 was found in 5 of the MWs $(125,242,262 *, 168$, and 185). T-RF 491 was dominant in only three MWs: 168, 236, and 242. T-RF 79 was dominant in replicate samples 197, 197* and only on other MW, 262. T-RF 203 was dominant, again in replicate samples: 197, 197*, and one other MW, 262. T-RF 137 was dominant only in replicate samples 197 and 197*. T-RF 492 was dominant in MW 168, 340 and 194. 


\section{North Wind}

Based on the requirements set forth, prior to the analysis of groundwater from the PGDP North West plume for T-RFLP: community profiling, the following should be true:

1. Community profiles will differ based on TCE concentrations,

2. Community profiles will differ based on geochemical or biogeochemical parameters,

3. Community profiles of the wells that were cleaned in the same time frame should look more similar to one another than those that were cleaned more recently or never,

4. All of the profiles should have similarities that "outweigh" the differences, i.e. if biofilm is present in all, should show similarities (e.g. anaerobic contribution).

In general, the diversity profiles/fingerprints of each monitoring well evaluated were greater than expected. Each well produced a clearly distinct profile, detailing the micro-niches and diversity of genetic and physiological activities of microbial populations in situ.

Based on this overall diversity and the distinct differences of each of the fingerprints generated, is it clear that:

a. There is no dominance of any one organism or even group of organisms in the groundwater plume evaluated (based on DNA amplification).

b. Dominant organisms from any given monitoring well are different than other monitoring wells, even those with similar geochemical or contaminant concentrations.

c. The groundwater evaluated for enzyme activity probe analysis was not biased by biofouling in the well heads/casings, and

d. Most importantly, the groundwater sampled represented distinct micro-communities present within the PDGP North West plume (as would be expected if the plume, rather than the well casings and associated biofilms, were being sampled and analyzed).

These data provide scientifically and statistically defensible results that the groundwater sampled and analyzed for enzyme probe activity was the result of sampling the groundwater plume (i.e. formation water), rather than sampling the micro-communities present in specific and/or individual well casings, or biofilms present therein. 
North Wind

\section{T-RFLP Profiles:}
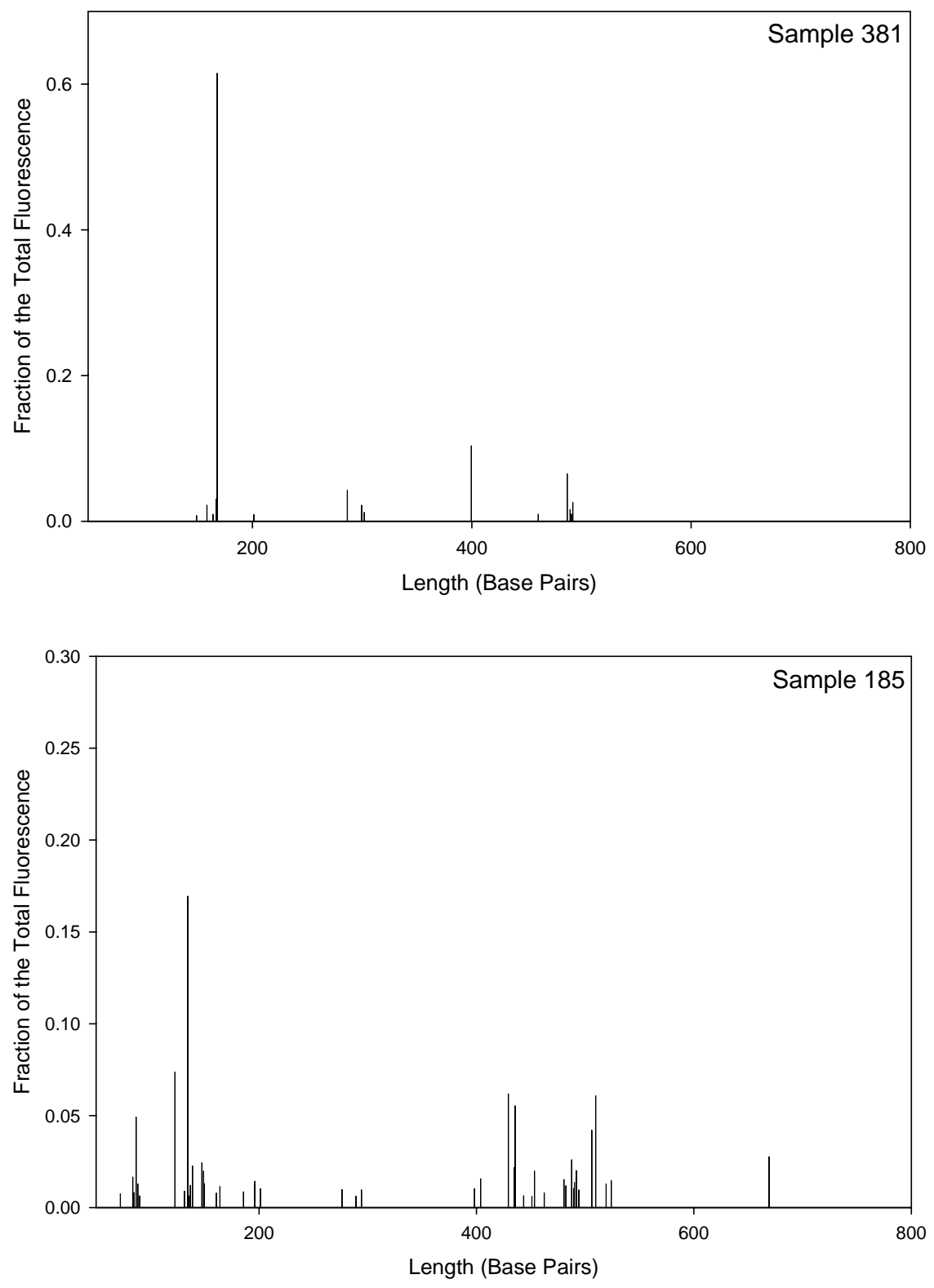
North Wind
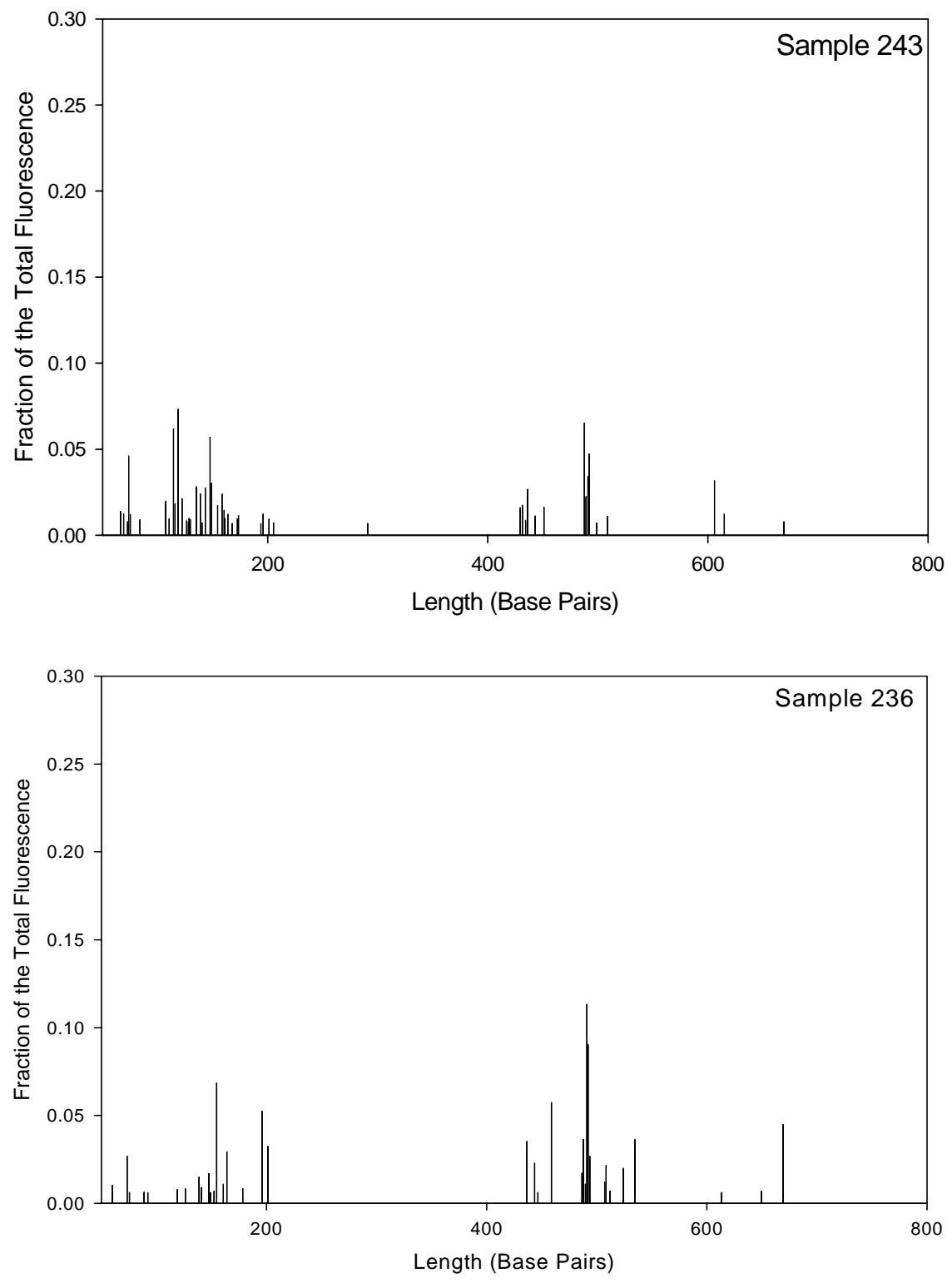
North Wind
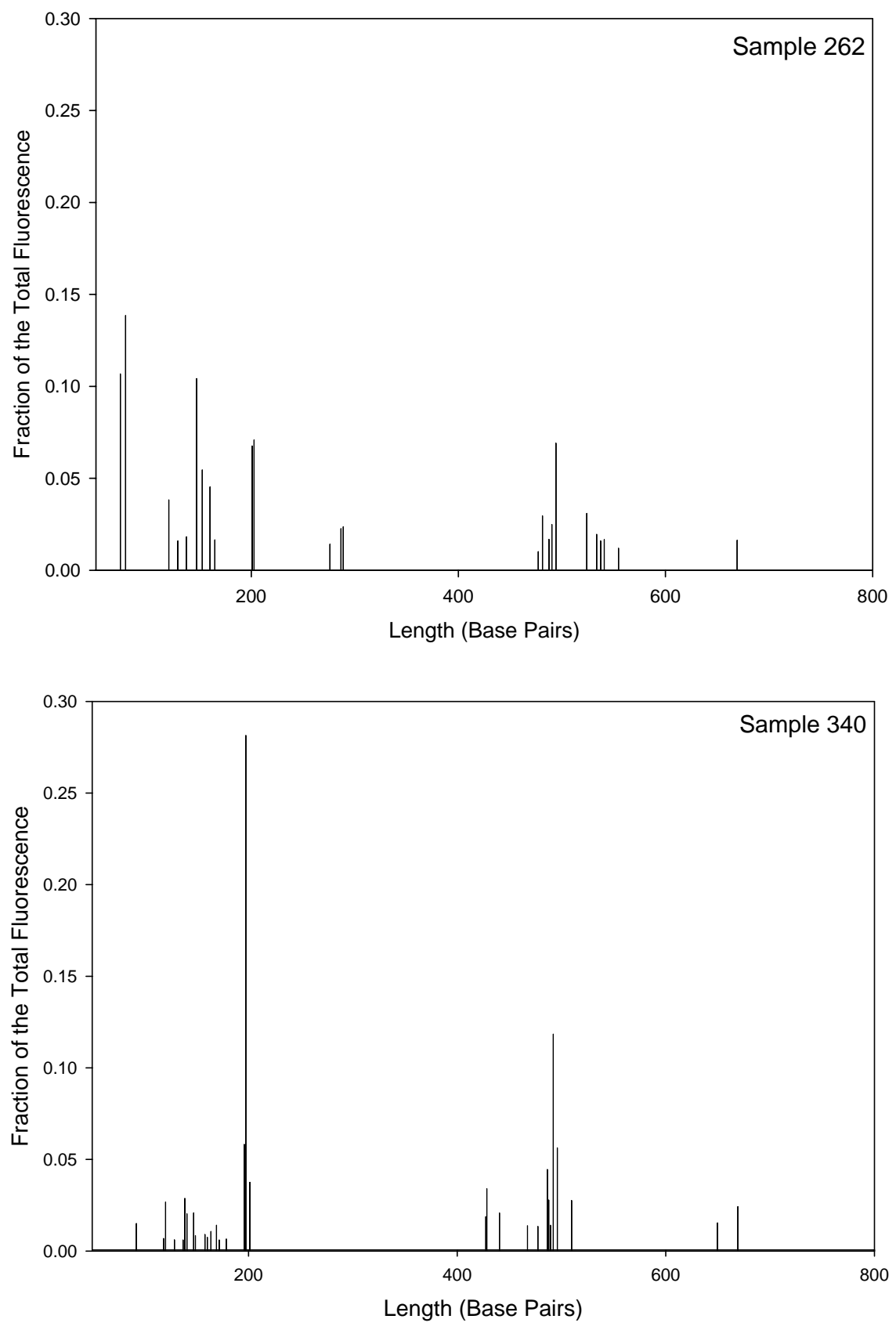


\section{North Wind}
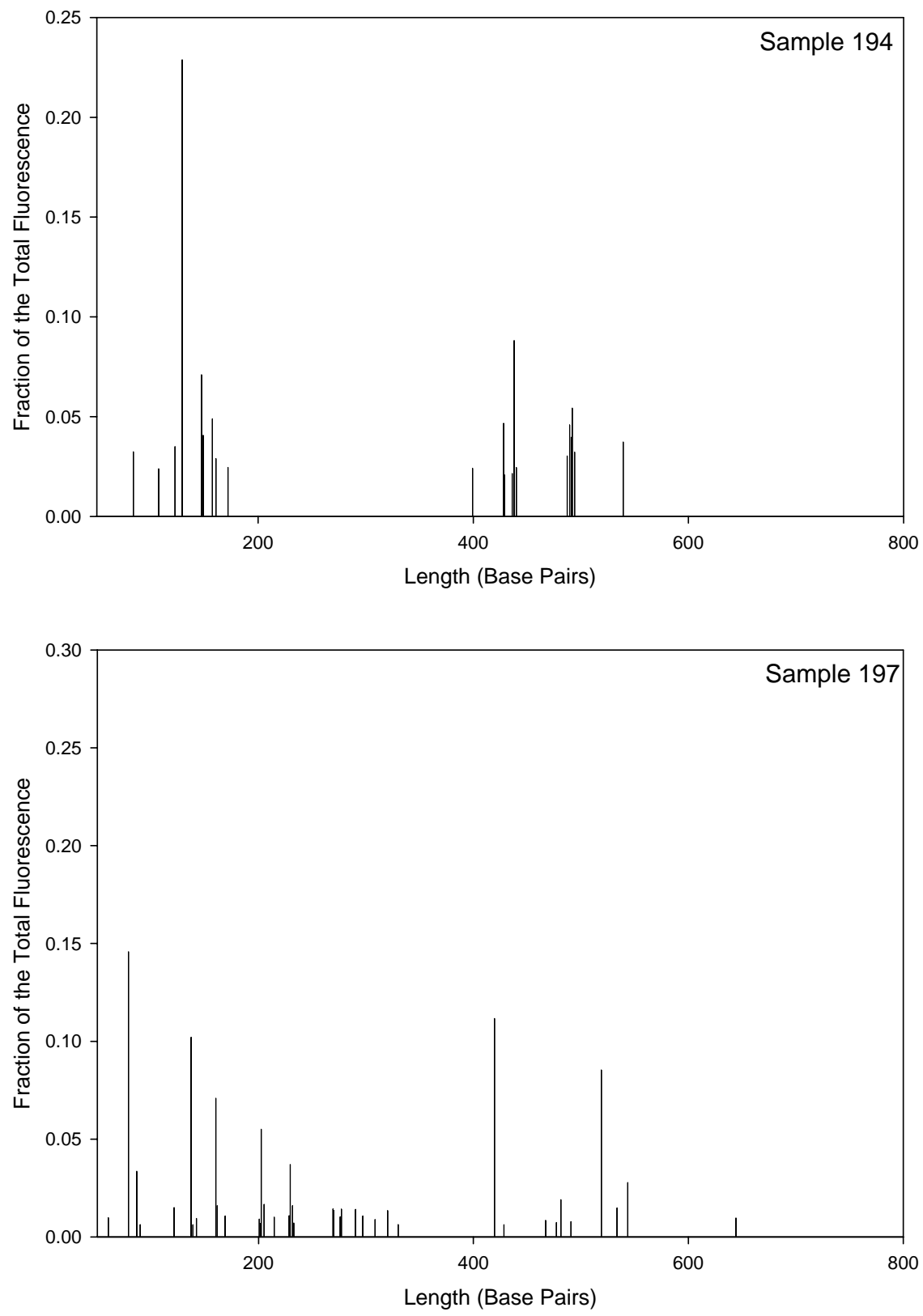
North Wind
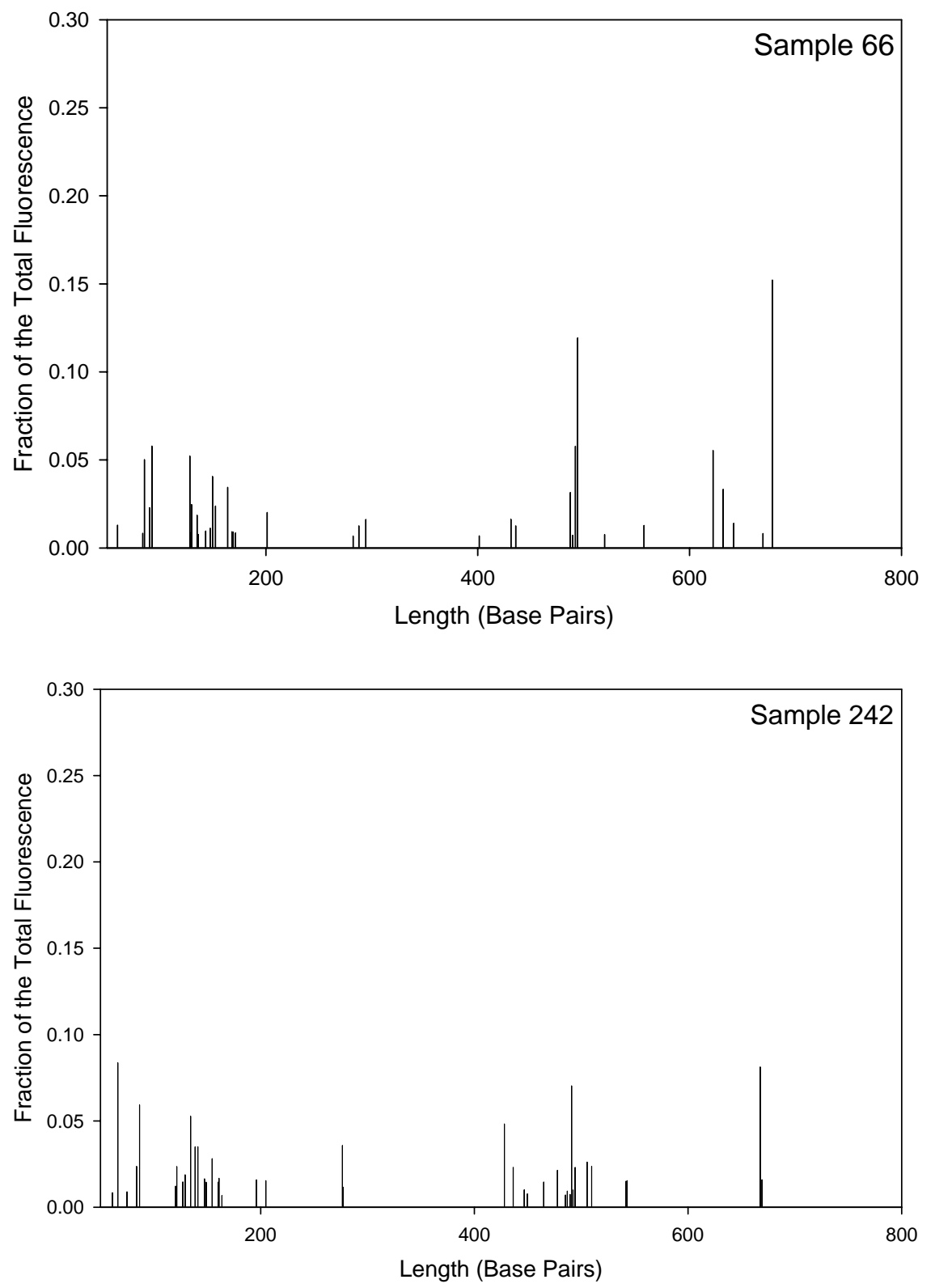
North Wind
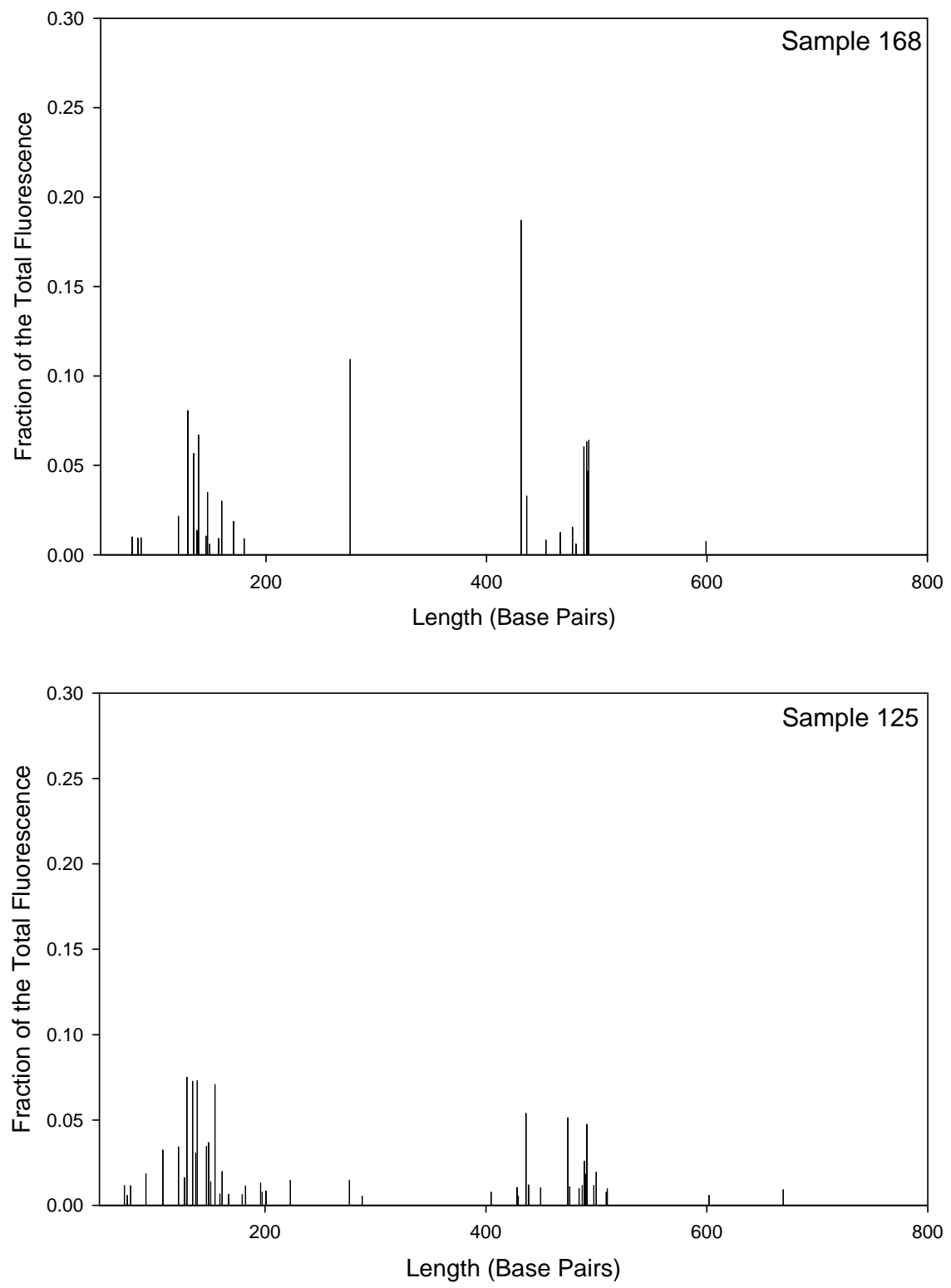
North Wind
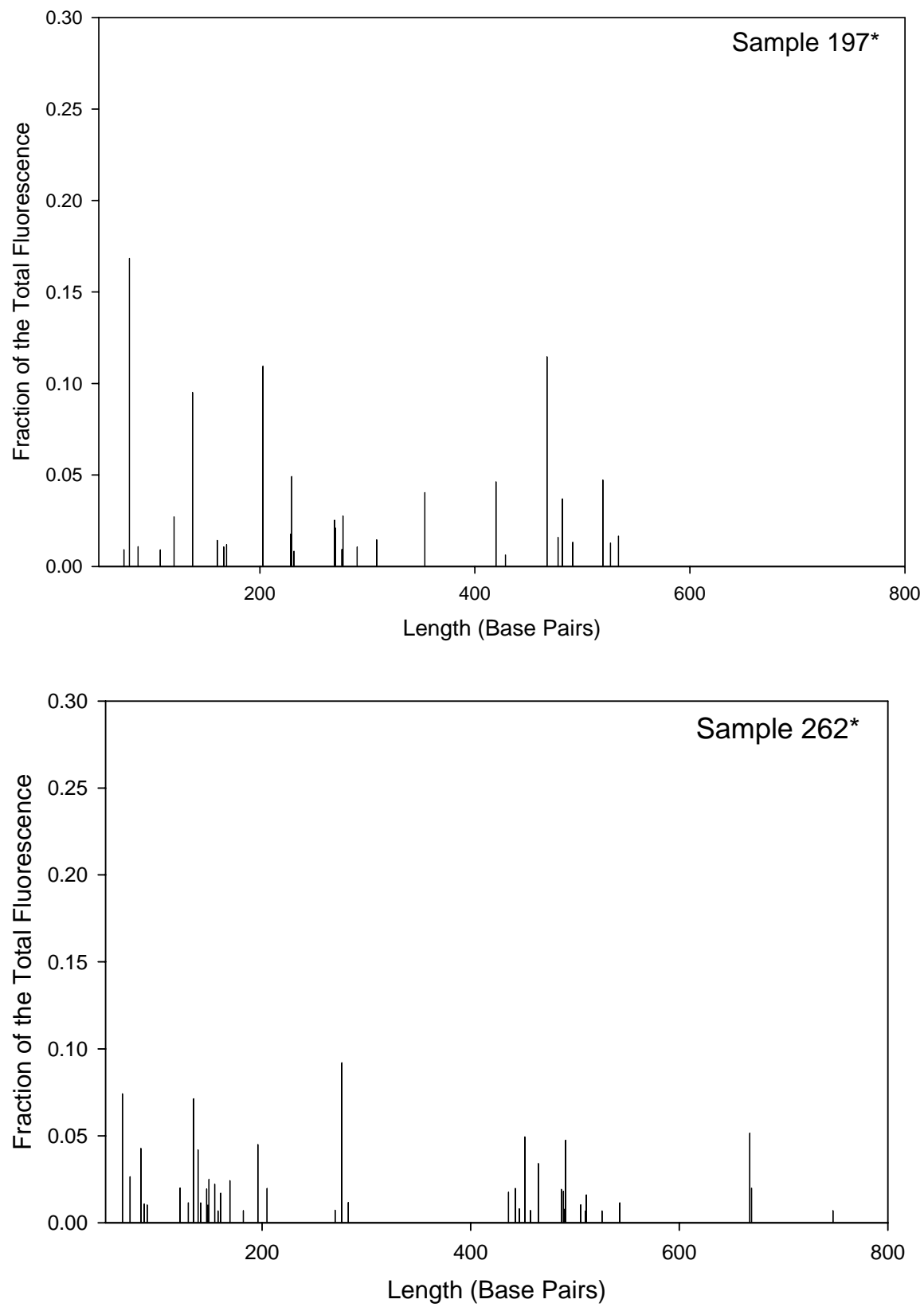